\author{
UNIVERSIDADE DE SÃO PAULO - USP \\ FACULDADE DE ARQUITETURA E URBANISMO - FAU \\ PROGRAMA DE PÓS-GRADUAÇÃO EM ARQUITETURA E URBANISMO
}

FERNANDA ANTONIO

Premissas e estratégias para uma Casa Solar visando à redução de emissões de gases de efeito estufa por meio da conservação e geração de energia.

São Paulo

2015 
EXEMPLAR REVISADO E ALTERADO EM RELAÇÃO À VERSÃO ORIGINAL, SOB RESPONSABILIDADE DA AUTORA E ANUÊNCIA DA ORIENTADORA.

O exemplar original encontra-se disponível na sede do Programa de Pós-

Graduação da Faculdade de Arquitetura e Urbanismo da Universidade de São Paulo.

São Paulo, 24 de maio de 2015. 


\section{FERNANDA ANTONIO}

Premissas e estratégias para uma Casa Solar visando à redução de emissões de gases de efeito estufa por meio da conservação e geração de energia.

Dissertação apresentada à Faculdade de Arquitetura e Urbanismo da Universidade de São Paulo, para a obtenção do título de Mestre em Arquitetura e Urbanismo.

Área de concentração:

Tecnologia da Arquitetura

Orientadora:

Prof. ${ }^{\text {a }}$ Dra. Claudia Terezinha de Andrade Oliveira

São Paulo

2015 
AUTORIZO A REPRODUÇÃO E DIVULGAÇÃO TOTAL OU PARCIAL DESTE TRABALHO, POR QUALQUER MEIO CONVENCIONAL OU ELETRÔNICO, PARA FINS DE ESTUDO E PESQUISA, DESDE QUE CITADA A FONTE.

E-MAIL DA AUTORA: nanda.antonio@gmail.com

Antonio, Fernanda

A635p Premissas e estratégias para uma casa solar visando à redução de emissões de gases de efeito estufa por meio da conservação e geração de energia / Fernanda Antonio. --São Paulo, 2015.

193 p. : il.

Dissertação (Mestrado - Área de Concentração: Tecnologia da Arquitetura) - FAUUSP.

Orientadora: Claudia Terezinha de Andrade Oliveira

1.Aquecimento global 2.Arquitetura 3.Conservação de energia elétrica 4.Energia solar I.Título

CDU 620.97 
Nome: ANTONIO, Fernanda

Título: Premissas e estratégias para uma Casa Solar visando à redução de emissões de gases de efeito estufa por meio da conservação e geração de energia.

Dissertação apresentada à Faculdade de Arquitetura e Urbanismo da Universidade de São Paulo, para a obtenção do título de Mestre em Arquitetura e Urbanismo.

Aprovado em:

Banca Examinadora

Prof. Dr.: Instituição:

Julgamento: Assinatura:

Prof. Dr.: Instituição:

Julgamento: Assinatura:

Prof. Dr.: Instituição:

Julgamento: Assinatura: 


\section{Agradecimentos}

Agradeço à Claudia, minha orientadora, que me acompanhou e guiou de forma tão generosa e competente nessa trajetória. Agradeço também pela confiança, dedicação e esmero, essenciais ao desenvolvimento desta dissertação, e pelo grande exemplo que é como professora, orientadora, e como pessoa.

Ao Miguel por todo conhecimento e sabedoria compartilhados.

Agradeço aos meus pais, Joanei e Teresinha, por todo apoio, carinho e incentivo na minha incursão pelo meio acadêmico.

À Dani, minha irmã, pelo apoio e amor que ela sempre me dá.

Agradeço ao Yuri, amigo querido, por todo apoio do início ao fim desta jornada.

A cada um dos amigos e colegas de equipe do projeto Ekó House, e que também são parte importante deste trabalho. Em especial ao Lucas, Tarsila, Kós, Themis, Umberto, Giulia, Jaca, Jorge, Thiago, Dudu, Cami, Lettícia, Rubia, Camilla, Pascoal, Rodrigo, Regis, Gabi, Felipe, Gustavo, Eduardo, Isaías, Edu, Marcão, e Shiro.

Agradeço aos professores José Aquiles Grimone e Norberto Moura por gentilmente aceitarem o convite para compor a banca de avaliação, e também por seu esmero na revisão e contribuições para esta dissertação.

Agradeço aos professores Jorge Saraiva, Norberto Moura e Paulo Kanayama pelas preciosas horas dedicadas a me assessorar nesta dissertação.

Aos queridos amigos Ciça, Fred, Pablo, Xu, Bruna, Karin e Lucas, pelo apoio e por sempre me receberem com tanto carinho nas minhas idas a São Paulo.

A todos os meus familiares e amigos, pelo apoio e incentivo.

A todas as empresas e parceiros que acreditaram e apoiaram o projeto Ekó House, em especial à Eletrobrás. 


\section{Resumo}

ANTONIO, F. Premissas e estratégias para uma Casa Solar visando à redução de emissões de gases de efeito estufa por meio da conservação e geração de energia. 2015. 193 f. Dissertação (Mestrado) - Faculdade de Arquitetura e Urbanismo, Universidade de São Paulo, São Paulo, 2015.

Esta dissertação tem por objetivo determinar a contribuição de uma unidade habitacional unifamiliar, que utiliza o sol como fonte principal de energia e adota premissas e estratégias de uma Casa Solar para a conservação e geração de energia, e redução de emissões de gases de efeito estufa (GEE). O Sistema Interligado Nacional (SIN) de eletricidade é analisado considerando as fontes de geração, emissões de GEE associadas e as projeções de expansão. São estudados o potencial e as limitações para a inserção da fonte solar fotovoltaica na matriz de energia elétrica brasileira. O consumo de eletricidade do setor residencial é caracterizado, considerando as previsões de aumento da demanda por eletricidade. São elencadas e estudadas as premissas e estratégias de uma Casa Solar, com foco no aproveitamento do sol na arquitetura e no uso de sistema de aquecimento solar (SAS) e sistema fotovoltaico (SFV). Estas premissas e estratégias são demonstradas de forma aplicada por meio do protótipo Ekó House, um modelo de residência de energia zero (REZ) que incorpora as premissas e estratégias de uma Casa Solar. As estratégias bioclimáticas e os sistemas solares são analisados considerando sua aplicação na cidade de São Paulo. A análise qualitativa de estratégias passivas e de baixo consumo para o condicionamento térmico demonstra um potencial de se aumentar em até $70 \%$ as horas de conforto no ano. Dentro dos parâmetros definidos e considerando um valor médio de consumo residencial, a adoção de tecnologias mais eficientes para iluminação demonstra um potencial de reduzir o consumo de eletricidade em até $12,5 \%$, e o uso de SAS apresenta um potencial para conservar até $16,3 \%$ da eletricidade consumida. A geração de energia elétrica por SFV, associada à adoção medidas de eficiência energética, demonstra potencial para atingir um balanço energético próximo a zero ou positivo. Com isso, estima-se um potencial de se evitar até 1,66 $\mathrm{t} \mathrm{CO}_{2}$ de emissões ao ano por unidade habitacional.

Palavras-chave: Aquecimento global. Arquitetura. Conservação de energia elétrica. Energia solar. 


\section{Abstract}

ANTONIO, F. Guidelines and strategies for a Solar House aiming to reduce greenhouse gases emissions through energy conservation and generation. 2015. 193 f. Dissertação (Mestrado) - Faculdade de Arquitetura e Urbanismo, Universidade de São Paulo, São Paulo, 2015.

This dissertation aims to determine the contribution of a single-family housing unit that harnesses the sun as a main energy source, and adopts guidelines and strategies of a Solar House, aiming energy conservation and generation, and greenhouse gases (GHG) emissions reduction. The Brazilian interconnected electricity system is analyzed regarding energy sources, associated GHG emissions and expansion projection. The electricity consumption in residential sector is characterized, considering the forecasting of increase in electricity demand. The guidelines and strategies for a Solar House are studied, focusing on the harnessing of sun in architecture and solar systems for domestic hot water (DHW) and electricity generation by photovoltaic (PV) systems. The practical application of these guidelines and strategies is exemplified by the Ekó House prototype, a zero energy housing model that incorporates a Solar House guidelines and strategies in its design. Bioclimatic strategies and solar systems are analyzed considering their application in São Paulo city. The qualitative analysis of passive and low consumption strategies points out a potential of increasing $70 \%$ of comfort hours in a year. Within the parameters defined and considering the Brazilian average consumption for dwellings, it is shown that the adoption of efficient technologies for lighting can save up to $12.5 \%$, and solar systems for DHW can save up to $16.3 \%$ of electricity consumption. The PV electricity generation associated to energy efficiency measures can reach a near zero energy balance or even a positive energy balance. Thus, it is estimated a potential of avoiding up to $1.66 \mathrm{t} \mathrm{CO}_{2}$ year for each dwelling.

Keywords: Global warming. Architecture. Electrical energy conservation. Solar energy. 

opção frente e verso. 


\section{Índice de llustrações}

Figura 1.1: População mundial de 1750 a 2050 (à esquerda); e população urbana e rural no mundo, 1950 - 2050 (à direita).

Figura 1.2: Recorde de concentração de $\mathrm{CO}_{2}$ na atmosfera (à esquerda); e registros e projeções do aumento de concentração de $\mathrm{CO}_{2}$ para os próximos anos em um cenário business as usual (à direita).

Figura 1.3: Emissões de $\mathrm{CO}_{2}$ de 1900 a 2040.

Figura 1.4: Energia consumida ao longo do ciclo de vida de uma edificação, estimado em 60 anos.

Figura 1.5: Relação entre geração e consumo de energia, e eficiência energética.......7

Figura 2.1: Participação de fontes na matriz de energia elétrica de diferentes países (ano de 2011).

Figura 2.2: Emissões de $\mathrm{CO}_{2}$ e consumo de energia per capita em diferentes países.16

Figura 2.3: Capacidade instalada por tipo de fonte em 31/12/2011 (MW). 17

Figura 2.4: Balanço de energia do SIN em 2012 (GWh). ....................................... 18

Figura 2.5: Aumento na capacidade instalada do SIN e de seus subsistemas............ 19

Figura 2.6: Evolução da capacidade instalada por fonte de geração no horizonte de 2021(GW e \%).......

Figura 2.7: Empreendimentos em construção no Brasil em 2012 (quantidade e participação).

Figura 2.8: Fator de emissão no SIN para a margem de operação e geração em usinas termelétricas convencionais no SIN.

Figura 2.9: Radiação solar no Brasil para o plano inclinado. 24

Figura 2.10: Demanda instantânea para subsistemas SE/CO e SUL 25

Figura 2.11: Perspectiva de redução de custo dos sistemas fotovoltaicos para o setor residencial.

Figura 2.12: Participação no consumo de energia elétrica por setor no Brasil em 2012.

Figura 2.13: Comparação entre consumo residencial de eletricidade e renda per capita em diferentes países. 
Figura 2.14: Distribuição do consumo de domicílios por faixa. 34

Figura 2.15: Consumo de eletricidade da rede por classe (GWh). .35

Figura 2.16: Participação dos equipamentos no consumo residencial brasileiro. 35

Figura 2.17: Participação das fontes no aquecimento de água para banho nos domicílios brasileiros.

Figura 2.18: Indicadores e aumento do uso de coletores solares nos domicílios brasileiros.

Figura 2.19: Efeito potência no consumo total por serviço e efeito líquido no consumo total por uso $(2013-2050)$. 39

Figura 2.20: Consumo de eletricidade por serviço energético e energia conservada para o setor residencial brasileiro nos horizontes de 2020 e 2050.

Figura 2.21: Consumo final por energético para o setor residencial em 2013 e 2050. 40

Figura 2.22: Consumo médio doméstico de energia elétrica por uso final. 40

Figura 3.1: Demandas por energia em edificações e estratégias e sistemas solares que atendem a essas demandas.

Figura 3.2: Protótipo Ekó House durante o SDE 2012, realizado na cidade de Madri, Espanha.

Figura 3.3: Planta baixa do protótipo Ekó House considerando sua implantação em Madri (Hemisfério Norte). 48

Figura 3.4: Movimento aparente do sol e geometria mais favorável para seu aproveitamento na arquitetura....

Figura 3.5: Povoado indígena de Acoma. .50

Figura 3.6: Carta solar e leitura das horas de insolação, azimute e altura solar. 51

Figura 3.7: Radiação solar diária média para a cidade de Madri. .52

Figura 3.8: Carta bioclimática adaptada e estratégias de condicionamento térmico. ..54

Figura 3.9: Sistemas solares passivos. .55

Figura 3.10: Coeficientes de sombreamento para diferentes elementos de proteção solar.

Figura 3.11: Diagramas do uso de estratégias de ventilação natural e umidificação... 62

Figura 3.12: Dados climáticos de Madri (à esquerda); e principais estratégias de projeto para Madri, em percentual de horas no ano (à direita).

Figura 3.13: Áreas de aberturas e elementos de proteção solar nas fachadas do protótipo Ekó House. 63 
Figura 3.14: Valores de transmitância térmica $\left(\mathrm{kW} / \mathrm{m}^{2} \mathrm{~K}\right)$ para diferentes materiais de vedação largamente utilizados em unidades habitacionais brasileiras e no protótipo Ekó House.

Figura 3.15: Medições de temperatura no interior do protótipo Ekó House durante o SDE 2012.

Figura 3.16: Valores de medição de temperatura e umidade relativa do ar no interior do protótipo Ekó House durante sua participação no SDE 2012.

Figura 3.17: Componentes CC, CRE e CRI, que caracterizam as diferentes formas da luz natural alcançar um determinado ponto no interior de uma edificação.

Figura 3.18: Acesso à iluminação natural em função da geometria em planta da edificação.

Figura 3.19: Relação entre iluminação natural e a Razão Janela-Parede.

Figura 3.20: Variação da iluminação natural conforme a profundidade do ambiente e orientação das aberturas.

Figura 3.21: Prateleiras de luz e o aumento da penetração da iluminação natural no ambiente interno. 70

Figura 3.22: Estratégias para aproveitamento da iluminação zenital em edificações. .71

Figura 3.23: Diferentes elementos de sombreamento utilizados no protótipo Ekó House. As fotografias (a), (b) e (c) ilustram diferentes posições para as persianas da fachada Sul; (d) ilustra a permeabilidade dos quadros de bambu; (e) ilustra as persianas internas, que podem ser completamente recolhidas para maior aproveitamento da iluminação natural; e (f) ilustra os elementos que obstruem a iluminação natural na janela do banheiro.

Figura 3.24: Iluminação artificial no protótipo Ekó House. 77

Figura 3.25: Medições de iluminância no protótipo durante sua participação no SDE 2012. 78

Figura 3.26: Ábacos indicando o percentual de radiação solar recebido por superfícies com diferentes orientações, para três regiões do Brasil.......................................... 79

Figura 3.27: Sistema de aquecimento solar e seus componentes........................... 80

Figura 3.28: Comparação entre diferentes tecnologias de coletores solares e sua eficiência.

Figura 3.29: Princípio modular dos fotovoltaicos, partindo da célula como unidade básica, para os diferentes arranjos possíveis.

Figura 3.30: Sistema fotovoltaico conectado à rede. .84

Figura 3.31: Tipologias de integração de SFV a edificações. .85

Figura 3.32: Integração de módulos fotovoltaicos a componentes da edificação. 85

Figura 3.33: Estrutura ajustável para os sistemas solares no protótipo Ekó House. ... 87 
Figura 3.34: Diagrama do SAS do protótipo Ekó House e características técnicas dos coletores solares.

Figura 3.35: Desempenho do SAS instalado no protótipo Ekó House, considerando o sistema com e sem reservatório para o armazenamento da água aquecida.

Figura 3.36: Geração de energia elétrica para o sistema fotovoltaico da Ekó House em Madri, em diferentes ângulos de inclinação.

Figura 3.37: Estrutura de um sistema de automação residencial. 92

Figura 3.38: Participação no consumo por equipamentos e sistemas no protótipo Ekó House.

Figura 3.39: Balanço energético anual do protótipo Ekó House .95

Figura 3.40: Medições de geração e consumo de eletricidade no protótipo Ekó House durante o SDE 2012.

Figura 3.41: Demandas, premissas e estratégias de projeto para uma Casa Solar. ...97

Figura 4.1: Dados de temperatura e umidade para a cidade de São Paulo. 100

Figura 4.2: Dados de precipitação, nebulosidade e insolação para São Paulo. 100

Figura 4.3: Incidência de radiação solar diária média para diferentes orientações em na cidade de São Paulo. 101

Figura 4.4: Carta psicrométrica gerada para a cidade de São Paulo, para o período de um ano. 104

Figura 4.5: Estratégias de projeto e sua efetividade ao longo do ano, em percentual de horas de conforto. 104

Figura 4.6: Ganho de horas de conforto adotando-se as estratégias (2) sombreamento de janelas, e (10) ganho solar passivo direto com baixa massa térmica. 106

Figura 4.7: Ganho de horas de conforto adotando-se as estratégias 2, 3, 4, 5, 7, 10 e 11, que não requerem consumo de energia, no cenário denominado Climatização $A$.

Figura 4.8: Ganhos de horas de conforto no ano agregando-se estratégias de baixo consumo de energia. 107

Figura 4.9: Potencial de conservação de energia entre diferentes tecnologias de iluminação artificial. 109

Figura 4.10: Sistemas de rastreamento do sol em um eixo (esquerda) e dois eixos (direita). 110

Figura 4.11: Médias anuais de radiação solar diária para a cidade de São Paulo, considerando distintas orientações e inclinações do plano de incidência..... 111

Figura 4.12: Médias mensais de radiação solar diária para a cidade de São Paulo nos meses de fevereiro e junho. 
Figura 4.13: Fração solar média mensal (\%) para os SAS calculados para a cidade de São Paulo.

Figura 4.14: Geração total anual dos SFV calculados conforme as faixas de consumo e as potencias típicas indicadas, para distintas orientações. 116

Figura 4.15: Potencial de conservação de eletricidade por estratégia em relação ao consumo médio mensal total de um domicílio.

Figura 4.16: Balanço energético resultante da adoção de estratégias para conservação e geração de energia elétrica. 120

Figura 4.17: Emissões evitadas pela conservação e geração de eletricidade 121

Figura 4.18: Emissões de GEE associadas à combinação de estratégias para conservação e geração de energia, comparadas a um cenário base. 121

Figura 4.19: Potencial de redução de emissões de GEE pela adoção das estratégias para conservação e geração de eletricidade por unidade habitacional (à esquerda) e em larga escala (à direita). 125 


\section{Índice de Tabelas}

Tabela 2.1: Demanda Instantânea Máxima (MW)

Tabela 2.2: Custo da eletricidade ofertada pelas distribuidoras e da eletriciadade fotovoltaica em função dos mecanismos de incentivo fiscal e financiamento.

Tabela 2.3: Potência típica por faixa de consumo. 30

Tabela 2.4: Posse média de equipamentos nos domicílios brasileiros (unidades de equipamento por domicílio)

Tabela 2.5: Ganhos em eficiência energética por tipologia de serviço para o setor residencial (ano base 2013).

Tabela 3.1: Propriedades de materiais quanto à transmitância térmica $(U)$ e tempo de atraso térmico.

Tabela 3.2: Materiais e isolamento térmico. 59

Tabela 3.3: Fator Solar para diferentes vidros e elementos de proteção. 60

Tabela 3.4: Iluminância por classe de tarefas visuais que se aplicam ao uso residencial.

Tabela 3.5: Diferenças entre os sistemas de iluminação artificial. .73

Tabela 3.6: Vantagens e desvantagens dos coletores solares do tipo plano fechado e a vácuo.

Tabela 3.7: Eficiência média de diferentes tecnologias de células fotovoltaicas. 84

Tabela 3.8: Tempo de retorno de energia e emissões de GEE para distintas tecnologias fotovoltaicas.

Tabela 3.9: Características técnicas e de desempenho do modelo de painel fotovoltaico adotado para o protótipo Ekó House.

Tabela 4.1: Estratégias de projeto apresentadas na ferramenta Climate Consultant 5.5. 102

Tabela 4.2: Valores limites de temperatura e umidade. 103

Tabela 4.3: Dados de entrada para cálculos de SAS para o município de São Paulo na ferramenta RETScreen®.

Tabela 4.4: Potência típica por faixa de consumo, potência utilizada no cálculo e especificações do sistema fotovoltaico adotado. 
Tabela 4.5: Consumo e geração de energia elétrica médios para domicílios brasileiros em 2013.

Tabela 4.6: Potencial de conservação de energia para domicílios brasileiros em 2013.

Tabela 4.7: Consumo, conservação, geração e balanço energético.

Tabela 4.8: Contabilização de emissões de GEE evitadas para uma unidade habitacional, considerando a operação mensal e anual, com base nas emissões contabilizadas para de um cenário base.

Tabela 4.9: Projeção de conservação de eletricidade e redução de emissões de GEE pela substituição de lâmpadas incandescentes por LFC e LED.

Tabela 4.10: Potencial de redução de emissões de GEE pela adoção de SAS em São Paulo.

Tabela 4.11: Potencial de geração de eletricidade e redução de emissões de GEE pela adoção de SFV.

Tabela 4.12: Potencial de redução de emissões de GEE pela combinação de estratégias para a conservação e geração de eletricidade. 


\section{Lista de Abreviaturas e Siglas}

ABNT - Associação Brasileira de Normas Técnicas

ANEEL - Agência Nacional de Energia Elétrica

ASHRAE - American Society of Heating, Refrigeration and Air Conditioning

BIPV - Building Integrated Photovoltaics

CC - Componente do Céu

CIN - Contribuição da lluminação Natural

CPFL - Companhia Paulista de Força e Luz

CRE - Componente Refletida Externa

CRI - Componente Refletida Interna

CS - Coeficiente de Sombreamento

EEZ - Edificações de Energia Zero

ENCE - Etiqueta Nacional de Conservação de Energia

EPE - Empresa de Pesquisa Energética

FLD - Fator de Luz Diurna

Fs - Fator solar

FS - Fração Solar

GEE - Gases de Efeito Estufa

GWP - Global Warming Potential

IPCC - International Governmental Panel on Climate Change

LED - Light Emitting Diodes

LFC - lâmpadas fluorescentes compactas 
MCTI - Ministério da Ciência, Tecnologia e Inovação

MDL - Mecanismo de Desenvolvimento Limpo

NZEB - Nearly Zero Energy Buildings

OCDE - Organização para Cooperação e Desenvolvimento Econômico

ONS - Operador Nacional do Sistema

P\&D - Pesquisa e Desenvolvimento

PBE - Programa Brasileiro de Etiquetagem de Edificações

PBMC - Painel Brasileiro de Mudanças Climáticas

PCH - Pequena Central Hidrelétrica

PCM - Phase Change Material

PROCEL - Programa Nacional de Conservação de Energia Elétrica

RCE - Redução Certificada de Emissão

REZ - Residência de Energia Zero

RJP - Razão Janela-Parede

RTQ-C - Requisitos Técnicos da Qualidade do Nível de Eficiência Energética de Edifícios Comerciais, de Serviços e Públicos

RTQ-R - Regulamento Técnico da Qualidade do Nível de Eficiência Energética de Edificações Residenciais

RVE - Redução Verificada de Emissão

SAS - Sistema de Aquecimento Solar

SD - Solar Decathlon

SDE - Solar Decathlon Europe

SFV - Sistema Fotovoltaico

SIN - Sistema Interligado Nacional

TCS - Taxa de cobertura solar 
TUSD - Tarifa de Uso do Sistema de Distribuição

TUST - Tarifa de Uso do Sistema de Transmissão

UNEP - United Nations Environment Programme

UNFCCC - United Nation Framework Convention on Climate Change 


\section{Sumário}

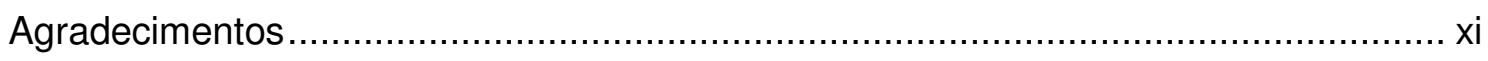

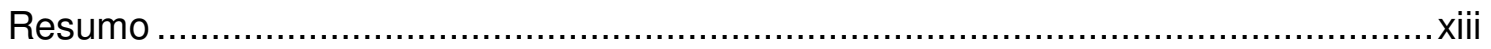

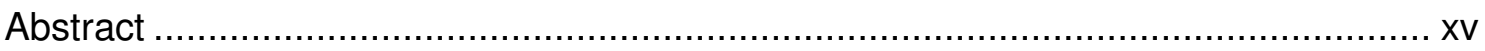

Índice de llustrações .........................................................................................

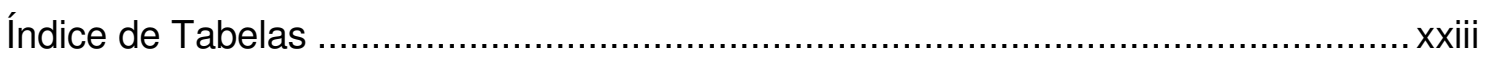

Lista de Abreviaturas e Siglas.....................................................................x

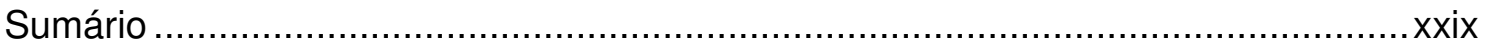

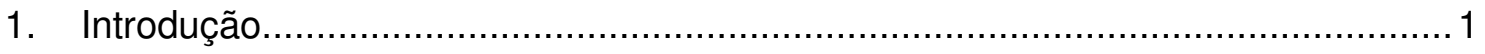

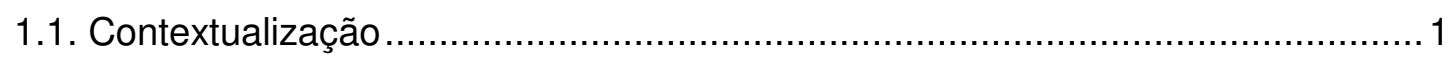

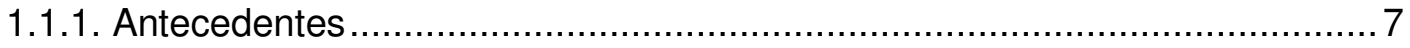

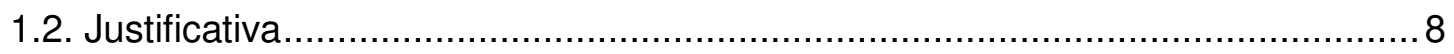

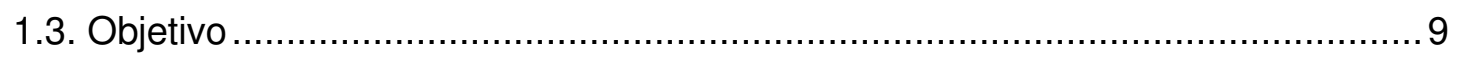

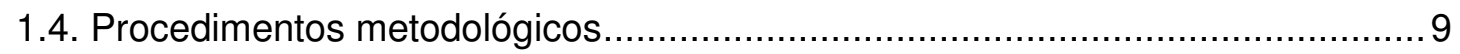

1.4.1. Coleta e organização de dados....................................................... 9

1.4.2. Análise dos resultados ................................................................. 11

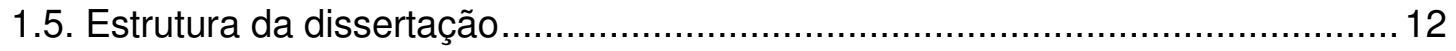

2. Geração de energia elétrica e consumo no setor residencial no Brasil .................15

2.1. Geração de energia elétrica no Brasil........................................................ 15

2.2. Emissões de GEE associadas à eletricidade no Brasil ................................ 21

2.1.1. Emissões de GEE no SIN e em sistemas fotovoltaicos .......................... 21

2.3. Inserção da geração solar fotovoltaica na matriz energética brasileira ..............24

2.3.1. Legislação de apoio à geração distribuída para sistemas fotovoltaicos......26

2.3.2. Viabilidade econômica e mercado para sistemas fotovoltaicos no Brasil ... 28

2.3.3. Projetos de Mecanismo de Desenvolvimento Limpo - MDL....................... 31

2.4. Consumo de eletricidade pelo setor residencial brasileiro ............................. 32 
2.5.1. Equipamentos e consumo de energia nos domicílios brasileiros. 35

2.5.2. Medidas de eficiência energética para o setor residencial ......................... 37

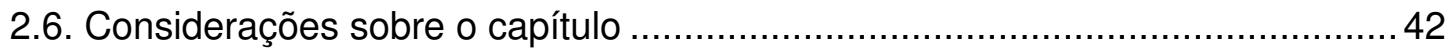

3. Premissas e estratégias para uma Casa Solar ............................................ 43

3.1. O aproveitamento do sol na arquitetura................................................... 43

3.2. Premissas, estratégias e sistemas para uma casa Solar ................................. 45

3.3. Protótipo Ekó House: exemplar de uma Casa Solar ....................................... 46

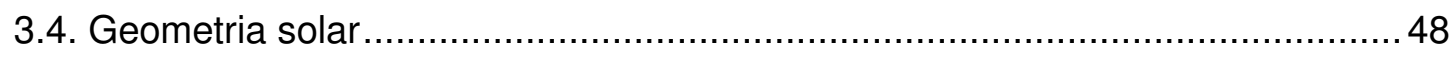

3.4.1. A geometria solar aplicada ao protótipo Ekó House ................................... 51

3.5. Estratégias para o conforto térmico .................................................... 52

3.5.1. Controle dos ganhos solares passivos .............................................. 54

3.5.2. Ventilação natural e resfriamento evaporativo ...................................... 61

3.5.3. Estratégias para o conforto térmico no protótipo Ekó House.......................62

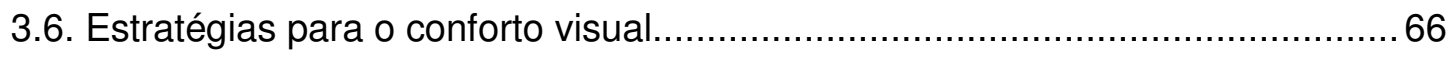

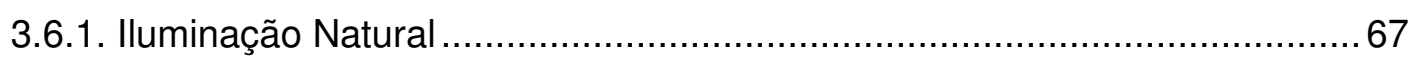

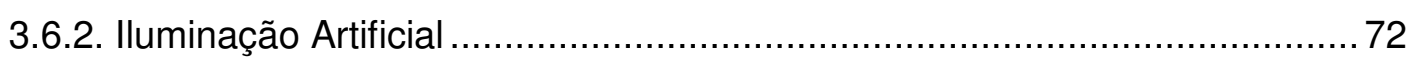

3.6.3. Estratégias para o conforto visual no protótipo Ekó House ....................... 74

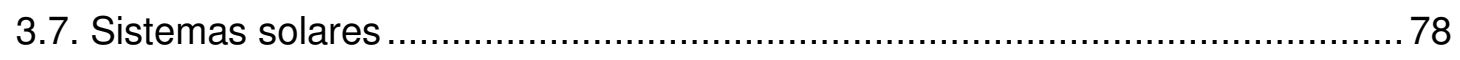

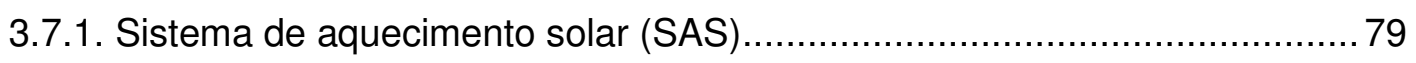

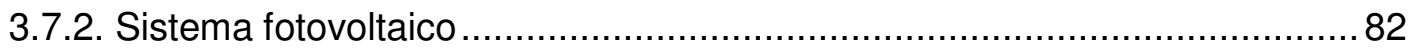

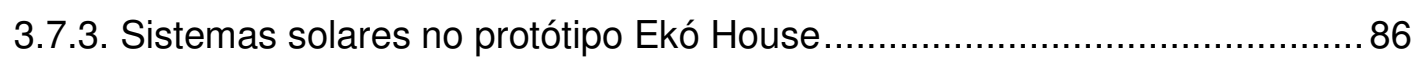

3.8. Consumo de energia em uma casa solar ................................................. 91

3.8.1. Balanço Energético no protótipo Ekó House ..........................................93

3.9. Sistematização das premissas e estratégias para uma Casa Solar .................. 96

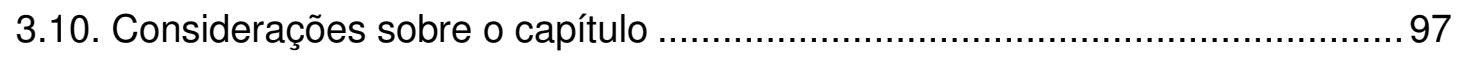

4. Aplicação do modelo de Casa Solar no contexto brasileiro...................................99

4.1. Cenário analisado para aplicação de uma Casa Solar no Brasil....................... 99

4.2. Análise bioclimática e o impacto de estratégias passivas no conforto térmico 101

4.3. Potencial de conservação de eletricidade para iluminação............................. 108 


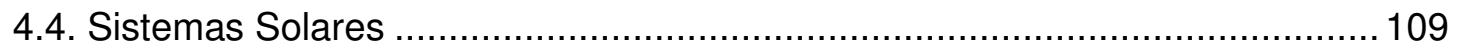

4.4.1. Sistema de aquecimento solar para aquecimento de água .................... 112

4.4.2. Geração de eletricidade por sistema solar fotovoltaico .......................... 114

4.5. Projeção do potencial de redução de emissões de GEE ...............................116

4.5.1. Projeção do potencial de redução de emissões de GEE em escala..........122

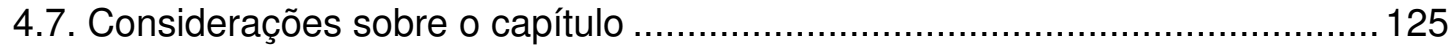

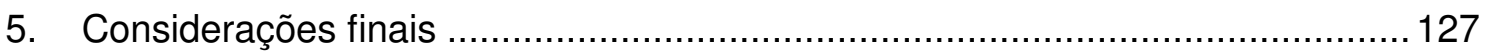

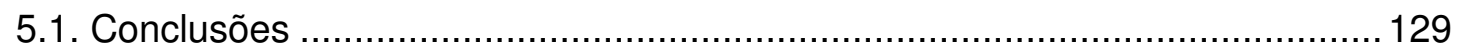

5.2. Sugestões para trabalhos futuros ........................................................... 131

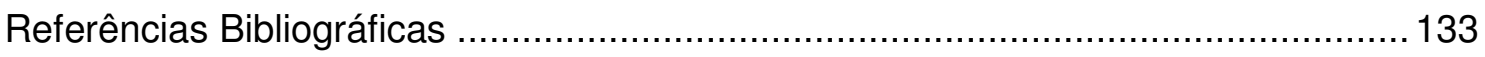

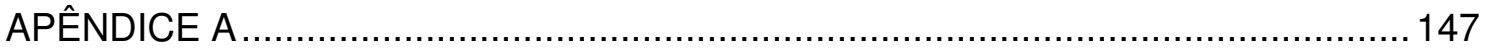

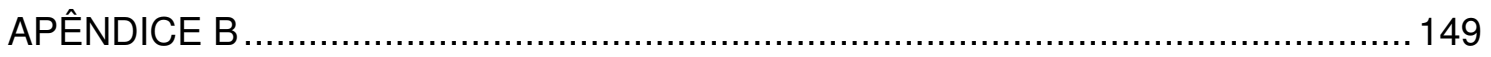

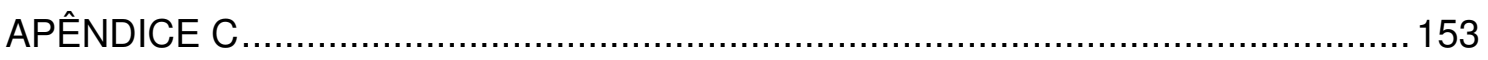

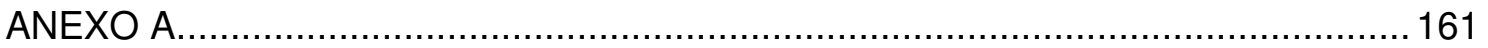



opção frente e verso. 


\section{Introdução}

\subsection{Contextualização}

O tradicional modelo de desenvolvimento econômico considera o meio ambiente fonte inesgotável de recursos naturais e destino final, com capacidade ilimitada, para receber os resíduos gerados pela atividade humana. Soma-se a isso a ineficiência e o desperdício no uso dos recursos naturais, notadamente da energia, que é um dos insumos essenciais para a provisão das condições básicas da vida humana. Desse modelo e da forma desequilibrada de exploração e uso desses recursos decorrem os atuais problemas ambientais.

A população humana, que atualmente soma cerca de 7 bilhões de habitantes no planeta, deve atingir mais de 9,5 bilhões no ano de 2050 (UNITED NATIONS, 2014). O gráfico à esquerda na Figura 1.1 ilustra este crescimento e permite observar que, a partir dos anos 1950, o crescimento da população mundial passou a aumentar a uma taxa sem precedentes ${ }^{1}$. Observa-se também uma tendência de aumento da população urbana no planeta. A projeção é de que, no ano de $2050,66 \%$ da população mundial esteja vivendo em áreas urbanas (UNITED NATIONS, 2014), conforme indicado no gráfico à direita na Figura 1.1
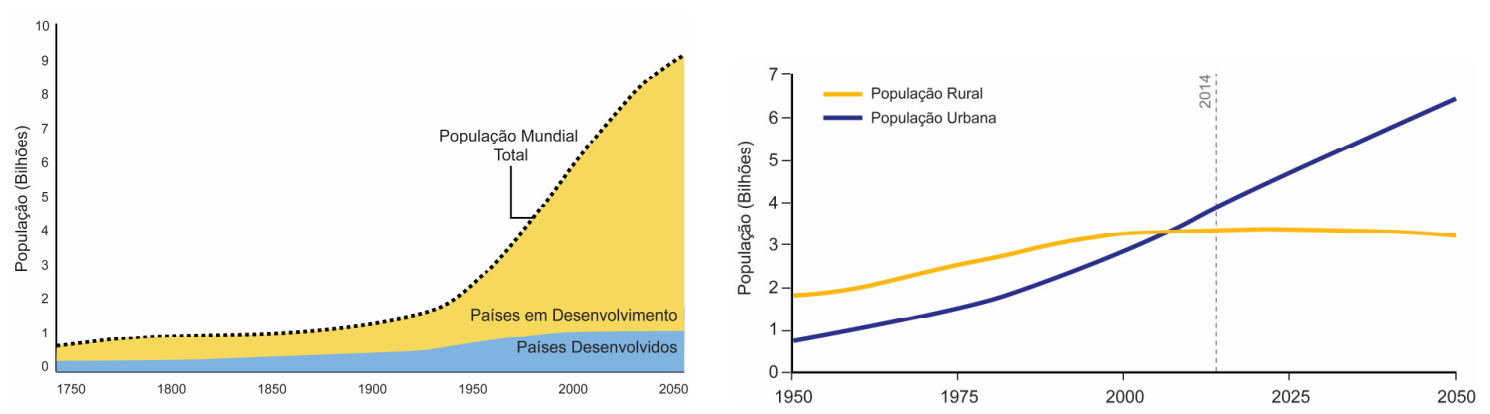

Figura 1.1: População mundial de 1750 a 2050 (à esquerda); e população urbana e rural no mundo, 1950 -2050 (à direita).

Fonte: A partir de SOUBBOTINA, 2004; UNITED NATIONS, 2014.

Com o aumento populacional, aumenta também a demanda por recursos naturais, bem como a quantidade de resíduos gerados pelas atividades humanas, dentre os quais

\footnotetext{
${ }^{1}$ Esse aumento expressivo a partir da década de 1950 está associado ao aumento da taxa de natalidade e redução da taxa de mortalidade (SOUBBOTINA, 2004).
} 
estão as emissões de gases de efeito estufa $(\mathrm{GEE})^{2}$, que contribuem para o fenômeno de mudanças climáticas ${ }^{3}$ e para o aquecimento global ${ }^{4}$. O Painel Intergovernamental sobre Mudanças Climáticas (IPCC - International Governmental Panel on Climate Change), em seu mais recente relatório de avaliação, o AR5 (Assessment Report), publicado em 2013, indica como "extremamente provável" (mais de 95\% de chances) que o aumento da temperatura na superfície da Terra entre os anos de 1951 e 2010 foi causado, majoritariamente, pelas atividades humanas (IPCC, 2013).

No Brasil, relatório publicado pelo Painel Brasileiro de Mudanças Climáticas (PBMC) indica que, até o ano de 2100, as mudanças no clima podem resultar em um aumento de temperatura ente $1^{\circ} \mathrm{C}$ e $6^{\circ} \mathrm{C}$ no território brasileiro (PBMC, 2013). Estes dados são baseados nos resultados científicos de modelagem climática global e regional, sendo a variação devida a diferentes cenários, considerando baixa ou alta emissão de GEE. Conforme pode ser observado nos gráficos da Figura 1.2, no ano de 2014, a concentração de $\mathrm{CO}_{2}$ na atmosfera atingiu o valor recorde de $399 \mathrm{ppm}^{5}$. As estimativas são de que nos próximos anos essa concentração siga aumentando, devendo atingir cerca de 1600 ppm nos próximos 300 anos, em um cenário tendencial (business as usual).
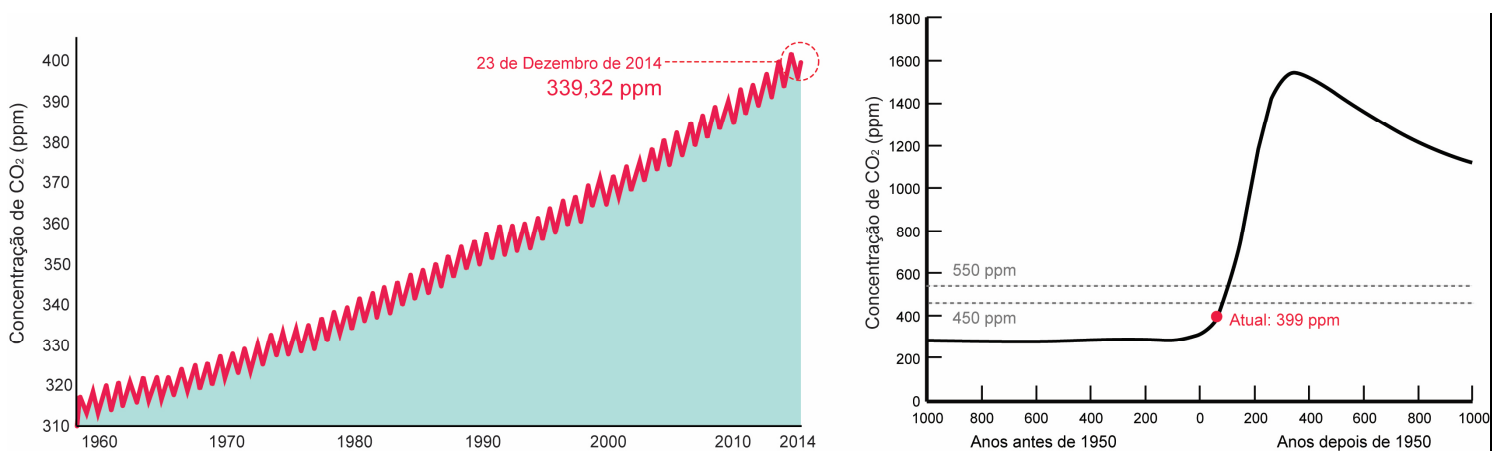

Figura 1.2: Recorde de concentração de $\mathrm{CO}_{2}$ na atmosfera (à esquerda); e registros e projeções do aumento de concentração de $\mathrm{CO}_{2}$ para os próximos anos em um cenário business as usual (à direita). Fonte: A partir de SCRIPPS INSTITUTION OF OCEANOGRAPHY, 2014.

\footnotetext{
${ }^{2}$ Os gases causadores do efeito estufa são os constituintes gasosos da atmosfera, naturais e antrópicos, e que absorvem e reemitem radiação infravermelha (UNFCCC, 2014). Os principais gases associados ao efeito estufa são o Dióxido de Carbono $\left(\mathrm{CO}_{2}\right)$, Metano $\left(\mathrm{CH}_{4}\right)$, Óxido Nitroso $\left(\mathrm{N}_{2} \mathrm{O}\right)$, Hidrofluorcarbonos (HFCs), Perfluorcarbonos (PFCs), e Hexafluoreto de Enxofre (SF6) (UNITED NATIONS, 1998).

${ }^{3}$ Mudança climática significa uma mudança no clima atribuída direta ou indiretamente à atividade humana e que altera a composição da atmosfera global e que é observada além da variabilidade climática natural, ao longo de períodos comparáveis (UNFCCC, 2014).

${ }^{4}$ As mudanças no clima podem levar ao aumento da temperatura na superfície da terra. No último relatório do IPCC, o AR5, o cenário mais otimista indica um aumento de $0,9^{\circ} \mathrm{C}$ a $1,7^{\circ} \mathrm{C}$; já a projeção mais pessimista é de que a temperatura possa aumentar de $2,6^{\circ} \mathrm{C}$ a $4,8^{\circ} \mathrm{C}$ (IPCC, 2014).

$51 \mathrm{ppm}$ de $\mathrm{CO}_{2}$ equivale a 2,13 Gt de Carbono. 1,0 Gt de Carbono equivale a 3,67 Gt de $\mathrm{CO}_{2}$. Sendo assim, $1 \mathrm{ppm}$ de $\mathrm{CO}_{2}$ equivale a aproximadamente 7,81 Gt de $\mathrm{CO}_{2}$. Dados disponíveis em: <http://www.ipcc.ch/ipccreports/tar/wg3/index.php?idp=477>, acessados em 15/02/2015.
} 
No mundo, as edificações comerciais e residenciais são responsáveis por 7,9\% do total de emissões de GEE (ROGNER et al., 2007). Nos países da Organização para Cooperação e Desenvolvimento Econômico $(\mathrm{OCDE})^{6}$, as edificações consomem entre 25 e 40\% do total de energia. Na Europa, a participação dos edifícios no consumo de energia está entre 40 e 45\%, contribuindo, consequentemente, com quantias significativas de emissões de $\mathrm{CO}_{2}$ (UNEP, 2007). No Brasil, 44\% da energia gerada é consumida em edificações (BRASIL, 2011b), sendo que o setor residencial é responsável por $26 \%$ do consumo de eletricidade no país (BRASIL, 2012). Se os países altamente populosos seguirem o mesmo modelo de produção e consumo dos países desenvolvidos, as consequências serão significativas, conforme aponta o gráfico da Figura 1.3, que indica um expressivo aumento nas emissões de GEE por parte de países em desenvolvimento após o ano de 2020.

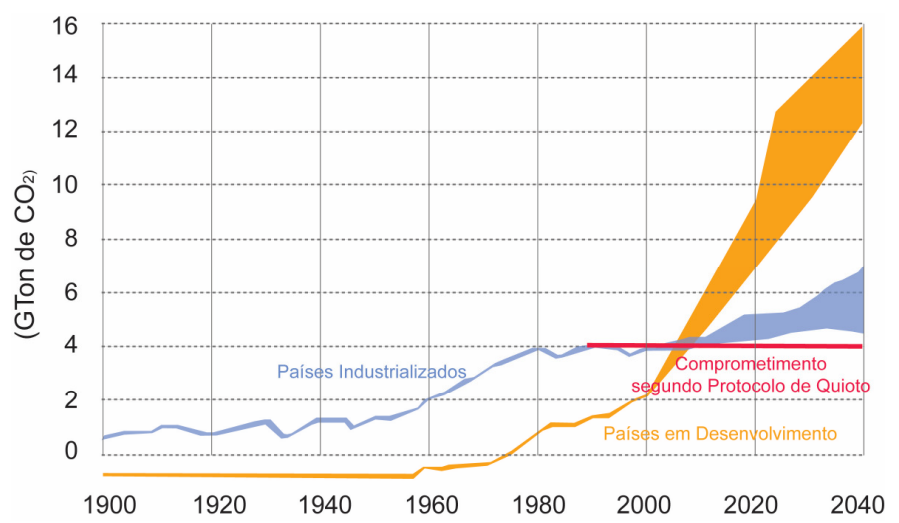

Figura 1.3: Emissões de $\mathrm{CO}_{2}$ de 1900 a 2040.

Fonte: A partir de UNEP, 2007.

O consumo de energia, que resulta em emissões de GEE, acontece nas distintas etapas que compreendem o ciclo de vida das edificações. De acordo com Jones ${ }^{7}$ (1998) apud UNEP (2007), o consumo de energia nas edificações ocorre basicamente em cinco etapas. A primeira corresponde à manufatura dos materiais e componentes da edificação, e é denominada energia incorporada. A segunda e terceira etapas correspondem, respectivamente, ao consumo para transporte de materiais e para a construção, sendo denominadas energia cinza e energia induzida. A quarta etapa corresponde à energia consumida na operação, ou uso, da edificação. Na quinta etapa

${ }^{6}$ A OCDE é composta por 34 membros, com sede em Paris, França. Fundada em 14 de dezembro de 1961, sucedeu a Organização para a Cooperação Econômica Europeia. "A OCDE atua nos âmbitos internacional e intergovernamental e reúne os países mais industrializados do mundo e alguns países emergentes [...]. No âmbito da Organização, os representantes efetuam o intercâmbio de informações e alinham políticas, com o objetivo de potencializar seu crescimento econômico e colaborar com o desenvolvimento de todos os demais países membros." Informação disponível no endereço eletrônico < http://www.sain.fazenda.gov.br/sobre-a-sain-1/ocde>, acessada em 13 Jan 2015.

7 Jones, David LI. 1998. Architecture and the Environment. London, Laurence King Publishing. 
se contabiliza a energia utilizada na demolição da edificação e também na reciclagem de suas partes e componentes. O gráfico da Figura 1.4 ilustra o consumo de energia nestas diferentes etapas, e é possível observar que a fase de ocupação é a mais representativa no consumo de energia ao longo do ciclo de vida das edificações.

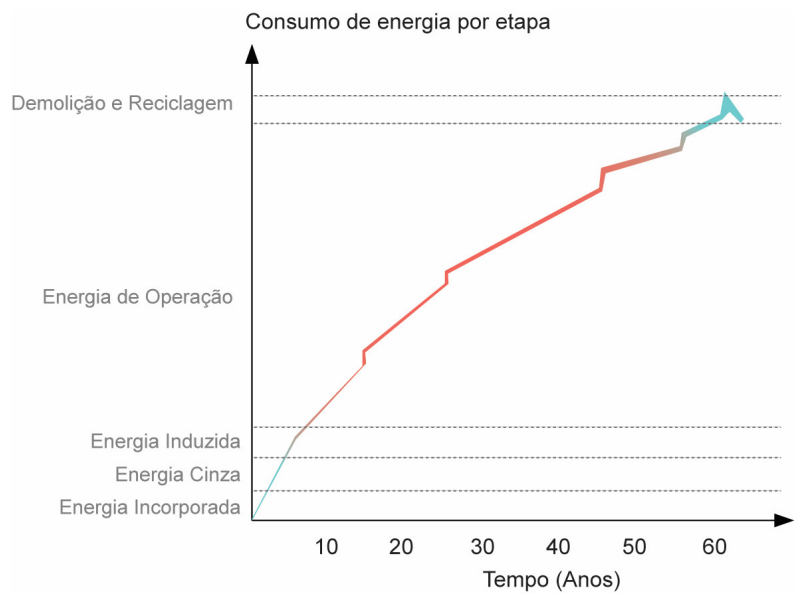

Figura 1.4: Energia consumida ao longo do ciclo de vida de uma edificação, estimado em 60 anos. Fonte: A partir de UNEP, 2007.

O Brasil é um país em desenvolvimento, e a tendência é de que a demanda por energia cresça juntamente com o país. Para atender à crescente demanda por eletricidade, conforme previsão do Plano Decenal de Expansão de Energia para 2021 (PDE 2021), serão necessárias novas usinas hidrelétricas, termelétricas e nucleares (BRASIL, 2012), acarretando significativos impactos ambientais, sociais e econômicos. Atualmente, no Sistema Interligado Nacional (SIN), que possui aproximadamente $96 \%$ da capacidade de produção de eletricidade do país, 69\% da energia elétrica são gerados a partir de hidrelétricas, e outros 9,5\% são gerados em pequenas centrais hidrelétricas ( $\mathrm{PCHs}$ ), usinas movidas a biomassa e eólicas.

A matriz de energia elétrica brasileira é considerada limpa devido à participação majoritária de usinas hidrelétricas (MEE, 2007). No entanto, cada vez mais se tem dado atenção aos impactos ambientais e sociais causados pela implantação de novas usinas hidrelétricas. Áreas imensas são alagadas, ocasionando perda de biodiversidade, de áreas cultiváveis e necessidade de deslocamento de populações inteiras. O equilíbrio ecológico e o microclima dessas áreas são alterados, e o processo de decomposição da vegetação das áreas alagadas gera gases que contribuem para o efeito estufa (LOMARDO, 2011).

No SIN, 15,4\% da energia elétrica é gerada por usinas térmicas convencionais (BRASIL, 2012), que também causam grandes impactos devido à liberação do calor rejeitado no processo de geração, às emissões de gases do efeito estufa (GEE), entre outros 
impactos. Além disso, o Brasil tem passado por períodos de baixa nos níveis dos reservatórios das usinas hidrelétricas, implicando a maior participação das usinas termelétricas no suprimento da demanda por eletricidade (AMATO, 2014).

Com o aumento da população, a crescente demanda por energia, e os impactos causados pela construção e operação de usinas convencionais para geração de eletricidade, observa-se necessidade de diversificar a matriz energética, priorizando fontes limpas e renováveis. Além disso, dada a participação das edificações no consumo de eletricidade, tanto no mundo quanto no Brasil, a implementação de medidas de eficiência energética apresenta enorme potencial para conter, ou mesmo reduzir, a demanda por eletricidade.

Diante deste contexto, apontam-se as Edificações de Energia Zero (EEZ) como forma de contribuir para o desenvolvimento sustentável ${ }^{8}$ do Brasil, de modo a permitir o bem estar da população com eficiência energética e redução dos impactos ambientais.

A definição de EEZ pode variar para se adequar a condições ou demandas especificas (TORCELLINI et al., 2006; PACHECO et al., 2013). Para o presente trabalho, adota-se a definição de Torcellini et al. (2006), segundo a qual uma EEZ é aquela que produz localmente, por meio de fonte renovável, energia suficiente para igualar ou exceder seu consumo anual de energia. A EEZ pode ser conectada à rede pública e integrar um sistema de geração distribuída de eletricidade.

Outro conceito que se aproxima ao de EEZ é o de Edifícios de Energia Quase Zero (tradução livre para o termo Nearly Zero Energy Buildings - NZEB). Este conceito é definido pelo Conselho Europeu para uma Economia com Eficiência Energética, segundo o qual o NZEB é um edifício com alto desempenho energético, e a quantidade de energia necessária para sua operação deve ser suprida por energia proveniente de fontes renováveis, gerada na edificação ou próximo a ela (ECEEE, 2009).

Uma das premissas das EEZ é a eficiência no consumo de energia para o seu uso e operação, portanto, faz-se necessário conceituar eficiência energética. Nesta dissertação, adota-se a definição de eficiência energética apresentada pelo Ministério do Meio Ambiente $(2013)^{9}$, segundo a qual:

\footnotetext{
8 Desenvolvimento sustentável é o desenvolvimento que satisfaz as necessidades presentes, sem comprometer a capacidade das gerações futuras de suprir suas próprias necessidades (WCED, 1987).

${ }_{9}^{9}$ MINISTÉRIO DO MEIO AMBIENTE: http://www.mma.gov.br/clima/energia/eficiencia-energetica. Acesso em 28/10/2013.
} 
“... eficiência energética consiste da relação entre a quantidade de energia empregada em uma atividade e aquela disponibilizada para sua realização. A promoção da eficiência energética abrange a otimização das transformações, do transporte e do uso dos recursos energéticos, desde suas fontes primárias até seu aproveitamento. Adotam-se, como pressupostos básicos, a manutenção das condições de conforto, de segurança e de produtividade dos usuários, contribuindo, adicionalmente, para a melhoria da qualidade dos serviços de energia e para a mitigação dos impactos ambientais."

Nesta mesma linha, o conceito de eficiência energética é apresentado por Lamberts et al. (1997, p. 14), onde "eficiência energética é a obtenção de um serviço com baixo dispêndio de energia. Portanto, um edifício é mais eficiente que outro quando proporciona as mesmas condições ambientais com menor consumo de energia."

No âmbito desta pesquisa, é também importante conceituar os termos 'conservação de energia' e 'energia conservada' que, nesta dissertação, são empregados de acordo com definição da EPE (2010) como sendo sinônimos do consumo de energia elétrica reduzido ou evitado. Neste sentido, o termo conservação não é aplicado no sentido físico ${ }^{10}$, mas como a redução efetiva do consumo, indicando o "processo (conservação) ou resultados de redução no consumo final de energia" (EPE, 2010, p. 4). Já o termo 'racional'11 é empregado para designar o consumo ou uso de recursos que busca minimizar ou evitar desperdício.

Haggard et al. (2009) apontam a relação entre geração de energia, consumo de energia e eficiência energética como uma consideração elementar em projetos que visam à eficiência energética. No entanto, a sociedade industrial isolou de tal modo a geração e o uso de energia que, ao priorizar o seu bem estar, as pessoas, habitualmente, não refletem sobre os impactos causados pelo consumo não racional de energia, e o resultado é que, embora a produção de energia venha se tornando mais eficiente, o consumo de energia é pautado pelo desperdício, especialmente nas edificações. Os diagramas da Figura 1.5 ilustram essa dissociação.

\footnotetext{
$10 \mathrm{Na}$ física, o termo conservação de energia se refere ao conceito de que a energia não pode ser criada ou destruída, apenas transformada, e de que a energia do universo é constante para qualquer sistema fechado, podendo somente mudar de forma.

11 Termo que se refere a algo aceitável pela razão, razoável, coerente, lógico, sensato (HOUAISS, 2009).
} 

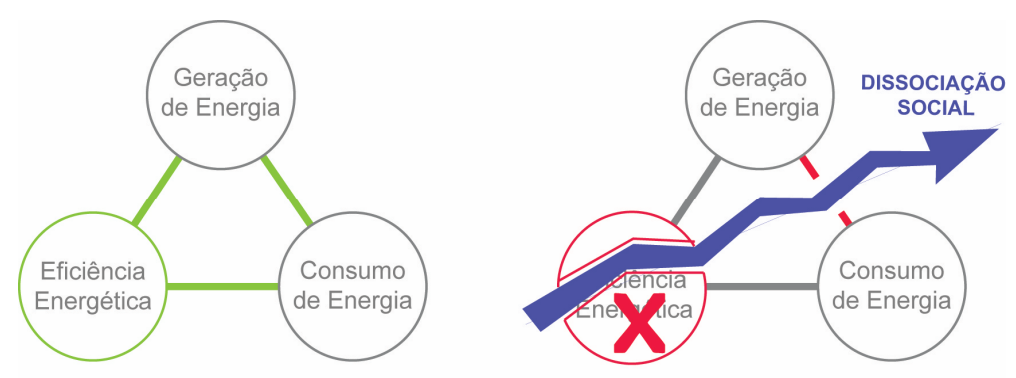

Figura 1.5: Relação entre geração e consumo de energia, e eficiência energética. Fonte: Adaptado de HAGGARD et al., 2009.

Pacheco et al. (2013) apontam as EEZ como importantes instrumentos no planejamento energético e na transição para uma matriz energética mais limpa, por meio do aumento da participação de fontes renováveis. As tipologias mais favoráveis para atingir o balanço zero, como é o caso das unidades habitacionais unifamiliares, devem ser priorizadas nas políticas de promoção de EEZ no Brasil (PACHECO et al., 2013). Por meio da eficiência energética e da geração distribuída de energia por fonte renovável, estes modelos de edificação podem impactar positivamente na diversificação da matriz energética e no consumo eficiente dos recursos naturais, reduzindo os impactos ambientais associados ao consumo de energia em edificações. Adicionalmente, as EEZ constituem um meio para reestabelecer a conexão entre geração e consumo de energia, podendo promover um consumo mais eficiente.

\subsubsection{Antecedentes}

A presente dissertação está inserida em um projeto de pesquisa e desenvolvimento (P\&D) de maior abrangência ${ }^{12}$. Esse projeto teve como meta iniciar o desenvolvimento de competência nacional para iniciar uma indústria de Residência de Energia Zero (REZ), com tecnologia própria e adequada às condições climáticas brasileiras. Como parte desse projeto de P\&D, foi desenvolvido o protótipo Ekó House ${ }^{13}$. Trata-se de um protótipo de habitação unifamiliar cujo projeto utiliza o sol como fonte para geração de energia e considera estratégias para manutenção do conforto ambiental e para uma operação eficiente em termos energéticos e ambientais. Este protótipo foi desenvolvido pela equipe Team Brasil, formada por uma parceria entre a Universidade de São Paulo e a Universidade Federal de Santa Catarina, e representou o Brasil na competição Solar

\footnotetext{
12 Projeto P\&D amparado pelo convênio ECV308/09 estabelecido entre Eletrobrás (Centrais Elétricas Brasileiras S.A.), Universidade de São Paulo (USP) e Fundação da Universidade de São Paulo (FUSP), considerando as diretrizes e o plano de ação do Programa Nacional de Conservação de Energia Elétrica (PROCEL).

13 www.ekobrasil.org
} 
Decathlon Europe ${ }^{14}$ (SDE), realizada em Madri, no ano de 2012. A competição SDE é descrita no Apêndice A.

O protótipo Ekó House integra diversas soluções para o aproveitamento do sol na arquitetura, visando proporcionar conforto ambiental para os ocupantes com baixo consumo de energia. Além disso, o protótipo incorpora sistema fotovoltaico (SFV) para geração de eletricidade, e sistema de aquecimento solar (SAS) para o aquecimento de água. Estes sistemas são dimensionados de modo a suprir toda a demanda por energia do protótipo, considerando o balanço anual (KÓS; ANTONIO, 2013; PROJETO EKÓ HOUSE, 2012). Sendo assim, o protótipo Ekó House responde ao conceito de EEZ e é tomado como referencial nesta dissertação.

A partir do histórico de desenvolvimento do referido projeto de $\mathrm{P} \& \mathrm{D}$, bem como do protótipo Ekó House, surgiu a presente pesquisa, com o intuito de verificar o potencial de conservação e geração de energia, bem como de redução da emissão de GEE mediante a aplicação de edificações nestes moldes ao contexto brasileiro.

\subsection{Justificativa}

Diante do contexto apresentado, tanto em escala mundial quanto nacional, mostra-se necessário voltar as atenções ao uso da energia em edificações. No Brasil, o setor residencial é responsável por cerca de um quarto do consumo total de eletricidade. Observa-se, portanto, o potencial deste setor para contribuir na redução do consumo de energia por meio da adoção de medidas de eficiência energética.

As premissas e estratégias das EEZ podem ser utilizadas no Brasil contribuindo para aumentar a participação de fontes renováveis na geração de energia e consequentemente, para a segurança energética e diversificação da matriz energética brasileira. Sendo as unidades habitacionais unifamiliares propícias a incorporar as premissas e estratégias das EEZ, justifica-se investigar os possíveis benefícios que esse modelo de edificação pode trazer por meio de uma operação mais eficiente do ponto de vista energético e ambiental, e da geração de energia elétrica por fonte limpa e renovável, neste caso a fonte solar $^{15}$. Analisando a implementação de edificações

\footnotetext{
14 www.sdeurope.org

15 Cabe esclarecer que, no que se refere à geração de energia elétrica por meio da fonte solar, a presente dissertação se devota ao estudo e análise da tecnologia fotovoltaica, com foco na geração distribuída. Existem outras tecnologias para gerar eletricidade a partir da fonte solar, a exemplo dos concentradores solares, cujo funcionamento consiste em captar a energia solar em uma grande área, por meio de concentradores solares, que refletem a radiação solar incidente em uma superfície menor, denominada
} 
baseadas no conceito de EEZ é possível verificar, no contexto brasileiro, as limitações e a contribuição deste modelo para o desenvolvimento sustentável do país.

O protótipo Ekó House é adotado como um exemplar de EEZ ou REZ ${ }^{16}$ que considera o aproveitamento do sol para a provisão do conforto ambiental e para geração de energia (térmica e elétrica) e, portanto, para efeito deste estudo também é denominado, alternativamente, de Casa Solar. O conceito de Casa Solar aqui adotado é mais amplo, abrangendo qualquer unidade habitacional que, dentro de suas possibilidades e limitações, tenha como premissa o adequado aproveitamento do sol como recurso para obtenção da eficiência energética, independentemente de atingir um balanço energético zero ou próximo a zero.

\subsection{Objetivo}

Determinar o potencial de contribuição de uma unidade habitacional unifamiliar que utiliza o sol como fonte principal de energia e adota as premissas e estratégias de uma Casa Solar para a conservação e geração de energia, e redução de emissões de gases causadores do efeito estufa.

\subsection{Procedimentos metodológicos}

Sendo de natureza aplicada, esta pesquisa explora os conceitos, práticas e diretrizes nos campos do projeto, construção, uso e operação de habitações unifamiliares que têm como premissas o uso do sol na arquitetura e na geração de energia, bem como a adoção de medidas de eficiência energética.

\subsubsection{Coleta e organização de dados}

Os procedimentos para a coleta dos dados compreenderam:

- Pesquisa bibliográfica: sobre assuntos relacionados às diretrizes de projetos residenciais com foco na eficiência energética e aproveitamento do sol; sistemas solares para geração de eletricidade e aquecimento de água; geração, transmissão, distribuição de eletricidade no Brasil; uso final de eletricidade em

foco. O material presente no foco é aquecido a altas temperaturas, podendo gerar vapor e, consequentemente, energia elétrica (ANEEL, 2005).

${ }^{16}$ O termo REZ é também empregado pois este estudo trata da tipologia habitacional unifamiliar. 
residências brasileiras; e redução de gases de efeito estufa, no âmbito do Mecanismo de Desenvolvimento Limpo (MDL);

- Pesquisa documental: base de dados do projeto Ekó House associada a dados obtidos por simulação computacional para a geração de energia elétrica a partir de SFV e energia térmica por meio de SAS para aquecimento de água, considerando a aplicação destes sistemas no Brasil.

A primeira etapa de pesquisa bibliográfica foi dedicada a uma análise do $\operatorname{SIN}$, atentando para a geração de energia elétrica e emissões de GEE associadas. Também foi estudado o consumo de eletricidade pelo setor residencial brasileiro, analisando a situação atual e projeções no horizonte de 2021 e 2050.

Foram estudados conceitos elementares dos MDL e metodologias específicas para a contabilização de emissões de GEE, considerando o contexto desta pesquisa.

Foi investigado o potencial de aproveitamento da fonte solar, considerando a disponibilidade desta fonte no país. Foi aprofundado o estudo das questões referentes aos mecanismos legais, de modo a compreender os avanços do país no incentivo à geração solar, bem como os obstáculos ainda presentes.

A segunda etapa da pesquisa bibliográfica permitiu a composição do referencial teórico na definição de diretrizes para projetos de Casa Solar, sendo dedicada ao estudo dos princípios bioclimáticos na arquitetura, com ênfase no aproveitamento do sol para a provisão do conforto ambiental (térmico e lumínico) aos ocupantes, com eficiência no consumo de energia. Foram estudados também os SFV, para geração de eletricidade, e SAS, para aquecimento de água, bem como sua integração às edificações.

As soluções arquitetônicas que têm como premissa o aproveitamento do sol por meio de estratégias passivas de condicionamento ambiental, bem como os sistemas de geração local de energia, permitiram a formulação de um referencial teórico para a análise de possibilidades técnicas e funcionais para melhoria das edificações residenciais brasileiras. As premissas são as orientações e diretrizes iniciais de projeto, e que são tomadas como base para definir quais as estratégias podem ser adotadas, dentre soluções arquitetônicas e sistemas solares a serem incorporados à edificação.

Nesta dissertação, o escopo de pesquisa foi limitado ao estudo e análise do consumo e geração de energia elétrica associado à fase de ocupação de unidades habitacionais, visto que esta fase é a mais representativa em termos de consumo de energia, conforme descrito no item 1.1 deste capítulo. 
$\mathrm{Na}$ etapa de pesquisa documental foram coletados e organizados dados sobre o processo de projeto, simulação das condições de conforto térmico e lumínico, simulações de produção e consumo de energia, montagem, uso e operação do protótipo Ekó House. Este protótipo foi selecionado como exemplar de REZ neste estudo devido à participação da autora em todas as etapas de desenvolvimento de projeto, montagem, exposição e operação do protótipo durante o evento Solar Decathlon Europe 2012.

Entre os dados resultantes de medições durante a operação do protótipo estão incluídas: variáveis de controle do conforto do ambiente interno do protótipo (temperatura, umidade relativa do ar interno, níveis de iluminância); produção de energia elétrica pelo SFV e consumo de eletricidade pelos eletrodomésticos e pelo sistema de iluminação artificial. A disponibilidade de documentação e dados referentes ao processo completo favoreceu a adoção do mesmo como estudo de caso nesta dissertação. A experiência adquirida pela autora e o acesso aos dados primários e documentos viabilizaram a análise crítica do desempenho do protótipo.

\subsubsection{Análise dos resultados}

A partir da revisão da bibliográfica, foi construído um cenário tendencial da produção e consumo de eletricidade no Brasil, usado como linha de base para análise das vantagens e limitações de se adotar as premissas e estratégias de uma Casa Solar em residências unifamiliares no país. Para exemplificar e analisar a aplicação de uma Casa Solar no contexto brasileiro foi definida a cidade de São Paulo como delimitação geográfica.

Com o estudo das premissas e estratégias para uma Casa Solar, exemplificadas pelo protótipo Ekó House, foi possível desenvolver uma análise qualitativa e quantitativa das possibilidades de implementação de tais soluções e sistemas em edificações residenciais unifamiliares brasileiras. A apresentação dos dados do processo de produção, uso e operação do protótipo Ekó House possibilitou interpretar o significado das soluções arquitetônicas e dos sistemas solares para geração de energia localmente.

$\mathrm{Na}$ análise qualitativa foram considerados o potencial de redução de consumo de eletricidade no uso e operação das edificações e o ganho obtido em termos de eficiência energética, tomando como base a pesquisa bibliográfica e a análise crítica sobre 0 protótipo Ekó House. O aumento de horas de conforto no ano associado à adoção de estratégias bioclimáticas, que impacta na redução do consumo de eletricidade, foi 
estimada por meio da ferramenta computacional Climate Consultant 5.5. Os critérios de seleção dos parâmetros adotados para os cálculos são apresentados no Capítulo 4. Com relação ao conforto lumínico, o foco foi dado ao potencial de redução de consumo por meio da adoção de tecnologias eficientes para a iluminação artificial. Embora a pesquisa bibliográfica traga exemplos de como o aproveitamento da iluminação natural pode contribuir para a eficiência energética e bem-estar dos ocupantes, a ênfase dada à iluminação artificial é justificada por sua representatividade no consumo de eletricidade no uso residencial.

A análise quantitativa foi desenvolvida a partir da contabilização da redução de emissões de GEE para uma residência que deixa de usar a eletricidade fornecida pelo SIN e passa a usar a energia obtida por meio dos sistemas solares para a climatização, aquecimento de água e iluminação artificial. Esta análise é realizada com base em simulações computacionais para a geração de energia por SFV e SAS. Nos dois casos, os cálculos foram realizados por meio do programa computacional RETScreen ${ }^{17}$. Os critérios de definição dos parâmetros adotados para os cálculos são apresentados no Capítulo 4. Dados referentes ao fator de emissão de GEE do SIN são oriundos de registros realizados e divulgados pelo Ministério da Ciência, Tecnologia e Inovação (MCTI), direcionados à aplicação em projetos de MDL no Brasil.

Por fim, foi analisada a contribuição deste modelo de Casa Solar em larga escala. Foram estudados diferentes arranjos de soluções, e distintos dimensionamentos para os sistemas solares, considerando uma unidade habitacional com o consumo médio brasileiro de eletricidade.

\subsection{Estrutura da dissertação}

A presente dissertação está estruturada em cinco capítulos, conforme descrito a seguir.

- Capítulo 2: Geração de energia elétrica e consumo no setor residencial no Brasil.

Apresenta dados sobre a geração de energia elétrica no SIN, as projeções de expansão do sistema, bem como as emissões de GEE associadas. O consumo pelo setor residencial brasileiro é caracterizado, e são analisadas projeções desse consumo no horizonte de 2021 e 2050. Também são analisados o potencial e as limitações para a inserção da geração solar na matriz de energia elétrica brasileira.

\footnotetext{
17 http://www.retscreen.net/
} 


\section{- Capítulo 3: Premissas e estratégias para uma casa solar}

Este capítulo traz uma revisão bibliográfica sobre soluções arquitetônicas relacionadas ao aproveitamento do sol na arquitetura por meio de estratégias passivas, visando o conforto ambiental dos ocupantes com baixo consumo de energia. São também estudados sistemas solares para geração de eletricidade e aquecimento de água (SFV e SAS), a eficiência de equipamentos e sistema de automação residencial como meios de melhorar a eficiência energética em edificações residenciais unifamiliares. A aplicação prática destas premissas e estratégias é exemplificada por meio de uma análise crítica do protótipo Ekó House, que é apresentado como um exemplar de Casa Solar.

\section{- Capítulo 4: Aplicação do modelo de Casa Solar no contexto brasileiro}

Este capítulo analisa a possibilidade de se aplicar um modelo de Casa Solar nos moldes do protótipo Ekó House, ou suas premissas e estratégias isoladamente, no contexto brasileiro. A análise foi desenvolvida considerando a cidade de São Paulo como delimitação geográfica. A fim de verificar as vantagens e limitações deste modelo, foi realizada uma análise qualitativa quanto à aplicação de soluções de projeto visando o aproveitamento do sol na arquitetura para obter uma maior eficiência energética, e uma análise quantitativa de geração de energia e redução de emissões de GEE, focada na adoção de sistemas solares (SFV e SAS).

\section{- Capítulo 5: Considerações finais}

O último capítulo é dedicado às conclusões, fechamento dos questionamentos levantados e das discussões desenvolvidas ao longo deste estudo. São também indicadas sugestões para trabalhos futuros que possam complementar os estudos apresentados nesta dissertação. 


\section{Geração de energia elétrica e consumo no setor residencial no Brasil}

Este capítulo é dedicado ao estudo da geração de eletricidade no SIN, e do consumo pelo setor residencial brasileiro. O SIN é descrito, considerando a participação de fontes na geração de eletricidade, emissões de GEE associadas à geração, além das previsões de expansão do sistema. É analisada a inserção da fonte solar na matriz de energia elétrica brasileira, considerando o potencial para exploração desta fonte no território nacional, aspectos legais e de viabilidade econômica. Para a contabilização de emissões de GEE, são abordados conceitos básicos dentro do MDL. Por fim, é caracterizado o consumo de energia elétrica no setor residencial, considerando a situação atual e projeções futuras de demanda, bem como a perspectiva de adoção de medidas de eficiência energética para este setor.

\subsection{Geração de energia elétrica no Brasil}

A matriz energética brasileira sempre se distinguiu internacionalmente pela alta participação de fontes renováveis de energia, inicialmente fruto dos empreendimentos hidrelétricos na produção de eletricidade e, mais tarde, pela introdução do álcool de cana de açúcar como carburante nos automóveis (BRASIL, 2007). Considerando especificamente a geração de eletricidade, se comparada às matrizes de países desenvolvidos, ou mesmo às de alguns países em desenvolvimento, é possível notar uma maior participação de fontes renováveis, representada majoritariamente pela geração hidrelétrica. Os gráficos da Figura 2.1 ilustram a participação de fontes na matriz de energia elétrica brasileira e de outros países. 

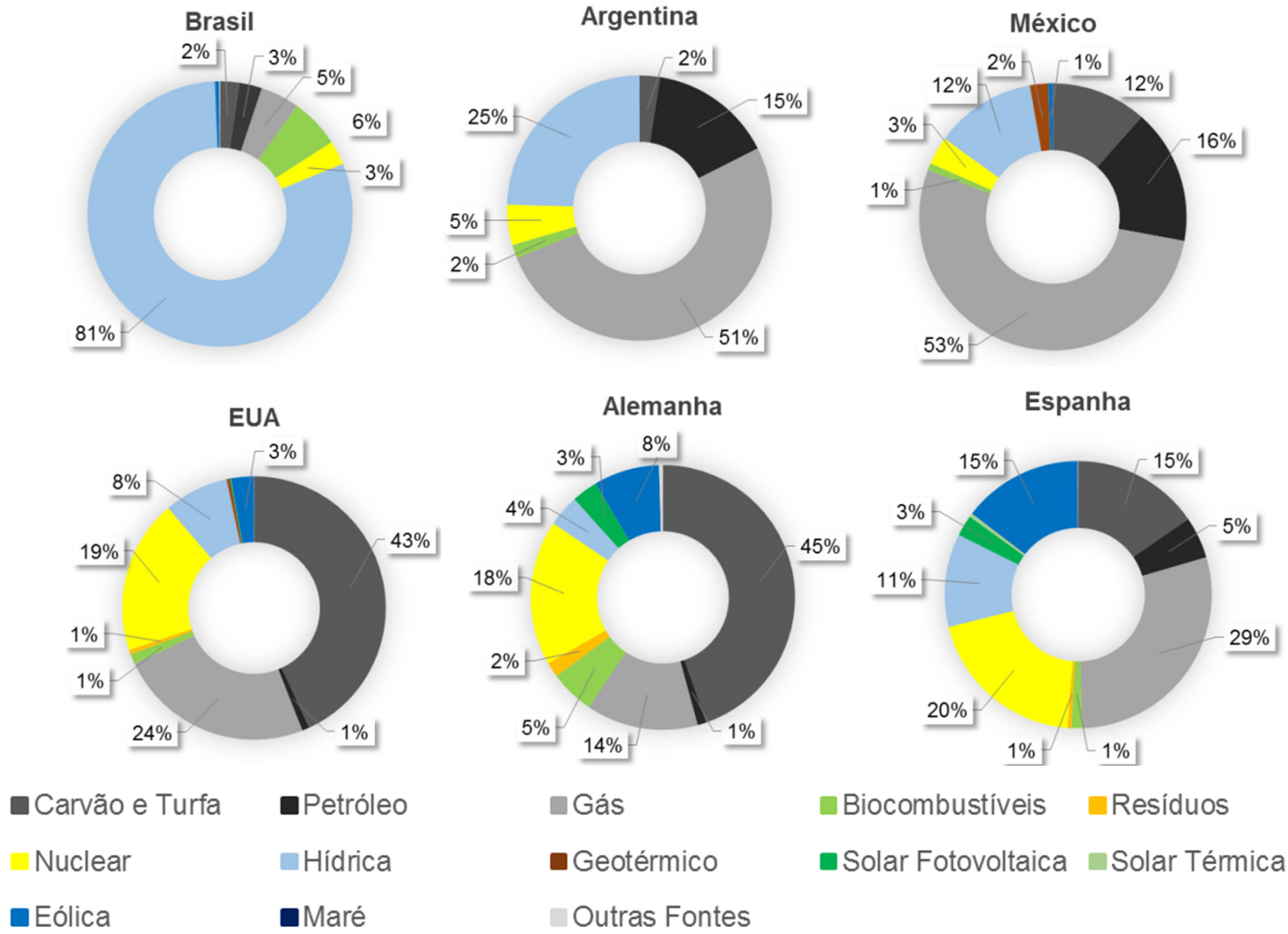

Gás

Biocombustíveis Resíduos

- Geotérmico

- Solar Fotovoltaica $\quad$ Solar Térmica

Outras Fontes

Figura 2.1: Participação de fontes na matriz de energia elétrica de diferentes países (ano de 2011). Fonte: Elaboração própria a partir de IEA, 2014

É possível observar que a matriz brasileira garante ao país um valor de emissões de GEE per capita inferior ao de países desenvolvidos, e mesmo ao de outros países emergentes, conforme demonstrado no gráfico na Figura 2.2.

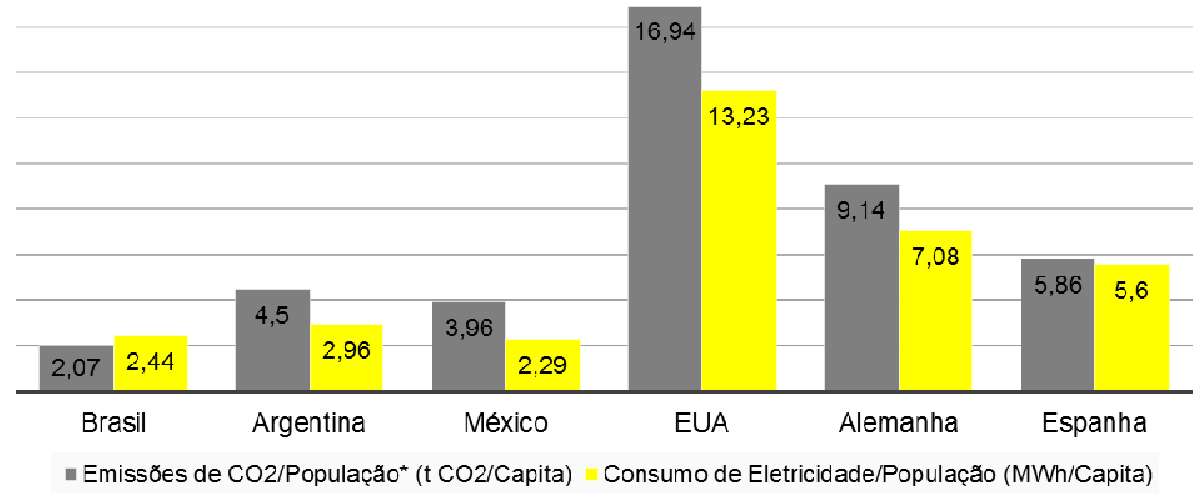

*Emissões associadas à queima de combustíveis, calculadas usando os balanços da IEA e Diretrizes Revisadas do IPCC de 1996.

Figura 2.2: Emissões de $\mathrm{CO}_{2}$ e consumo de energia per capita em diferentes países. Fonte: Elaboração própria a partir de IEA, 2014.

Ainda que os níveis de emissões sejam mais baixos, uma maior diversificação da matriz de energia elétrica é importante para o Brasil no sentido de redução de impactos ambientais, econômicos e sociais decorrentes da instalação de novas usinas de porte, 
tanto hidrelétricas como termelétricas. A busca do uso equilibrado dos diferentes recursos e soluções técnicas disponíveis também é necessária, de modo a melhorar a segurança, confiabilidade e a sustentabilidade no fornecimento de eletricidade no país, mantendo ou reduzindo os níveis de emissões de GEE.

O SIN é o sistema de produção e transmissão de energia elétrica brasileiro, com predominância de usinas hidrelétricas. O SIN comporta aproximadamente $96 \%$ da capacidade de produção de eletricidade do país, sendo que apenas 3,4\% da capacidade de produção de eletricidade encontram-se fora do SIN, em pequenos sistemas isolados localizados principalmente na região amazônica (ONS, 2012).

Dados apresentados no Anuário Estatístico Brasileiro de Energia Elétrica (EPE, 2013a) indicam que as usinas hidrelétricas geram cerca de $67 \%$ da energia no SIN, as termelétricas são responsáveis por 14\%, seguidas das renováveis Biomassa, $\mathrm{PCH}$ e Eólicas, que juntas geram cerca de $12 \%$ da energia elétrica. A geração nuclear participa com $2 \%$, e $5 \%$ são importados, conforme demonstra o gráfico da Figura 2.3. Atualmente a fonte solar ${ }^{18}$ ainda não é representativa na capacidade instalada de geração elétrica no Brasil, com uma geração de 8MW para aproximadamente uma geração total da ordem de 120.973MW.

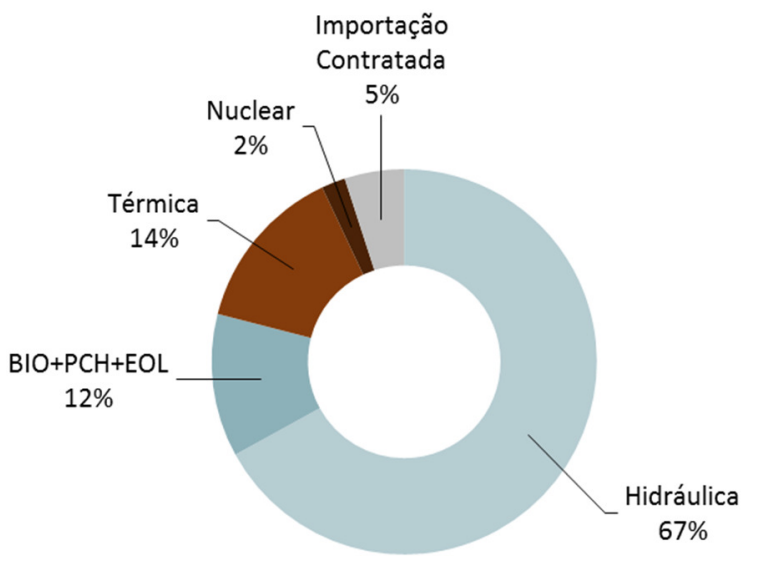

Figura 2.3: Capacidade instalada por tipo de fonte em 31/12/2011 (MW).

Fonte: Elaboração própria com base em BRASIL, 2012.

No SIN existe a necessidade de se corrigir, ao longo do tempo, deficiências no sistema que geram perdas nas etapas de transmissão e distribuição inaceitáveis em alguns pontos do país (BRASIL, 2007). Em 2012, as perdas de energia no SIN foram de 16,9\%, e a previsão é de que se reduza para 16,1\% até 2021 (BRASIL, 2012). Observa-se, ainda, a necessidade de intercâmbio de energia entre subsistemas do SIN para atender a demanda em diferentes regiões do Brasil, conforme ilustra a Figura 2.4. A distância

18 Tanto a tecnologia fotovoltaica quanto os concentradores solares são ainda pouco presentes no Brasil, seja na escala da geração distribuída ou em usinas de porte. 
entre os pontos de geração e consumo de eletricidade contribui para as perdas nas etapas de transmissão e distribuição de energia elétrica no SIN.

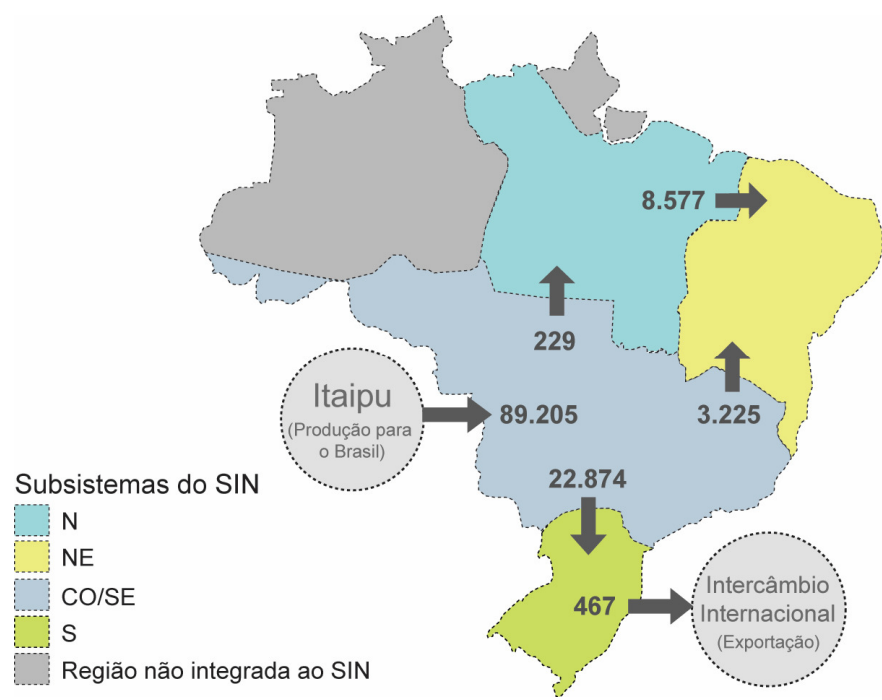

Figura 2.4: Balanço de energia do SIN em 2012 (GWh).

Fonte: Elaboração própria a partir de ONS, 2014.

Para atender à crescente demanda por eletricidade, será necessária a expansão do SIN. As hidrelétricas, segundo estudos especializados, continuarão sendo a principal fonte para a geração de energia elétrica no Brasil (BRASIL, 2012). No entanto, a maior parte, senão todo o recurso hídrico das regiões Sul e Sudeste já está sendo explorado, e a maior parte das reservas restantes encontra-se na Amazônia, longe dos centros industriais e populacionais do país (OECD, 2001). A expansão do SIN conta com a construção de novas usinas termelétricas, além da usina nuclear Angra III, com previsão de estar concluída em 2018. Isso implicará impactos sociais e ambientais, bem como no aumento de emissões de GEE.

A pressão por parte da sociedade organizada em resposta aos impactos gerados pela implantação dessas novas usinas, como a Usina de Belo Monte, tem se intensificado. Embora a geração hidrelétrica seja renovável, é importante lembrar que impactos socioambientais significativos estão associados à implantação destas usinas, conforme descrito no Capítulo 1.

Considerando a lógica do desenvolvimento sustentável, a futura demanda por energia deveria ser atendida com base em estratégias focadas em medidas de eficiência energética e no uso de fontes renováveis. Faz-se necessário, portanto, compreender não apenas o SIN, mas também as projeções para sua expansão. O gráfico da Figura 2.5 indica o aumento na capacidade instalada do SIN no horizonte de 2021. 


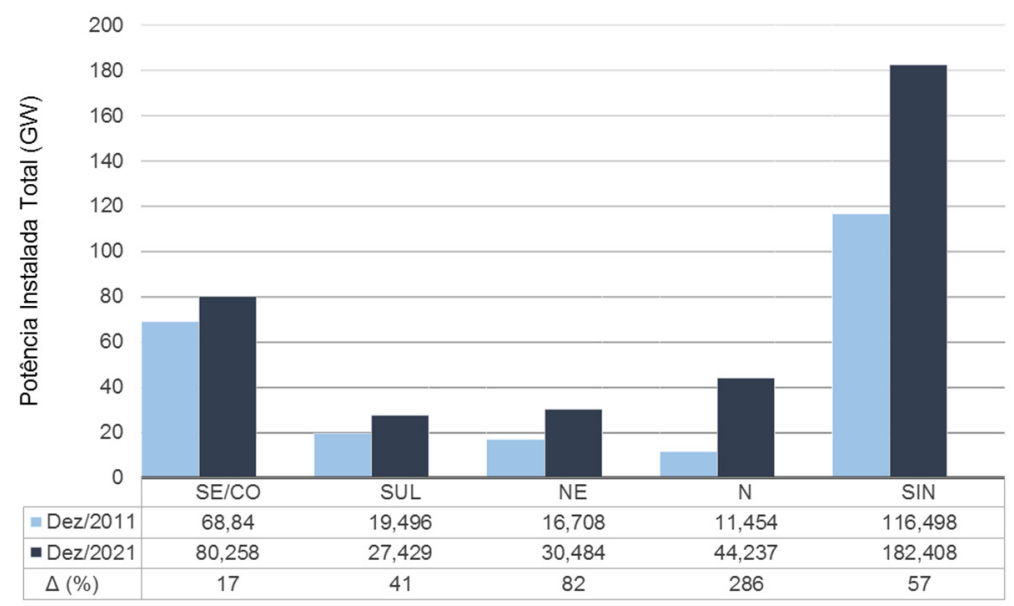

Figura 2.5: Aumento na capacidade instalada do SIN e de seus subsistemas. Fonte: BRASIL, 2012.

A potência instalada no SIN deve aumentar em $57 \%$, sendo que na Região Norte deve ocorrer o aumento mais significativo, onde a potência instalada deve triplicar, devido principalmente às novas usinas hidrelétricas previstas para a região. No gráfico da Figura 2.6 é demonstrada a participação das fontes prevista para a expansão do SIN, onde se observa que as hidrelétricas seguem predominando na geração, com uma participação de 65\% dentre as fontes de geração no horizonte de 2021.
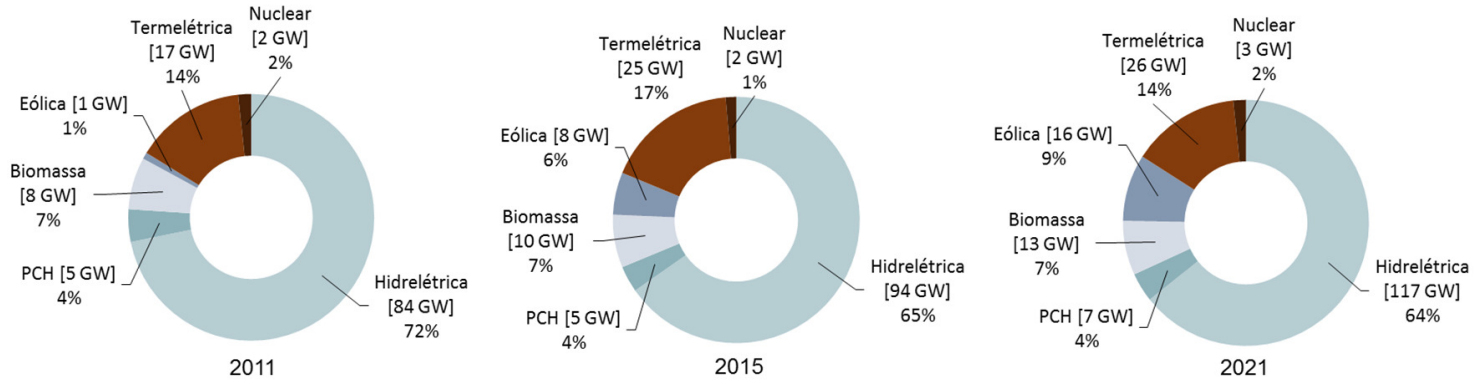

Figura 2.6: Evolução da capacidade instalada por fonte de geração no horizonte de 2021 (GW e \%). Fonte: BRASIL, 2012.

Observando os empreendimentos para geração de energia que estão em construção no Brasil, indicados no gráfico da Figura 2.7, constata-se que as principais fontes nos empreendimentos em construção no país seguem sendo hídrica e térmica. Entre as renováveis, centrais eólicas e $\mathrm{PCH}$ são as mais expressivas, sendo que não há previsão de centrais solares fotovoltaicas ${ }^{19}$ no horizonte decenal. $O$ fato de as centrais solares fotovoltaicas terem custos estimados significativamente maiores do que os registrados nos leilões de energia nova, gera dificuldade para estas centrais se tornarem competitivas frente às demais fontes nos próximos anos (EPE, 2013a). Além disso, a energia gerada nestas centrais estaria sujeita às perdas nas etapas de transmissão e

\footnotetext{
${ }^{19}$ Central Solar Fotovoltaica é uma instalação que, por meio de um sistema fotovoltaico, converte radiação solar diretamente em energia elétrica (EPE, 2013a). Trata-se de uma forma de geração solar fotovoltaica centralizada, portanto, muitas vezes distante dos pontos de consumo.
} 
distribuição, o que dificulta ainda mais a viabilização econômica destes empreendimentos no país. Como forma de compensar estas perdas para quem investe em geração renovável, a Agência Nacional de Energia Elétrica (ANEEL) aprovou, no ano de 2012, regras para descontos na Tarifa de Uso do Sistema de Distribuição (TUSD) e na Tarifa de Uso do Sistema de Transmissão (TUST), reduzindo em 50\% as tarifas para usinas de até $30 \mathrm{MW}$ que utilizarem a fonte solar (ANEEL, 2012).

Para o aproveitamento da fonte solar por meio de SFV, a geração distribuída é a alternativa que se encontra mais próxima da viabilidade econômica no país, já tendo alcançado a paridade ${ }^{20} \mathrm{com}$ as tarifas na rede de distribuição em algumas áreas de concessão, conforme descrito no item 2.3.2.

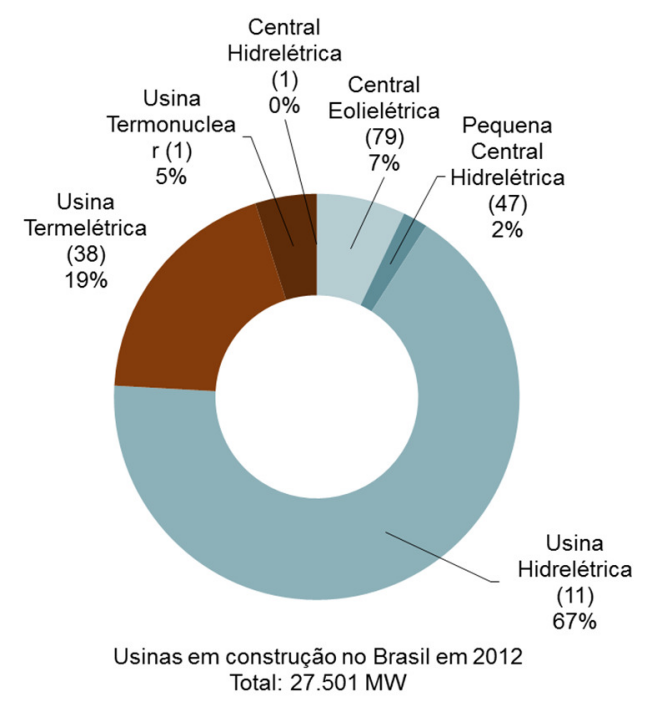

Figura 2.7: Empreendimentos em construção no Brasil em 2012 (quantidade e participação). Fonte: A partir de EPE, 2013a.

A geração prevista para os empreendimentos atualmente em construção é de 27.501 MW e, para o horizonte de 2021, a projeção é de que o consumo aumente cerca de 65.910 MW. A tendência da concentração do potencial instalado na Região Norte do país, distante dos centros consumidores, observável no gráfico da Figura 2.5, bem como as perdas de energia no intercâmbio entre subsistemas do SIN, são condições que apontam favoravelmente à geração solar fotovoltaica distribuída como alternativa para contribuir na expansão do SIN, pois aproxima geração e consumo, reduzindo as perdas nas etapas transmissão e distribuição.

\footnotetext{
${ }^{20}$ A paridade tarifária se refere à equiparação entre o custo de geração e o valor da tarifa praticada pelas distribuidoras (ZILLES et al., 2012).
} 


\subsection{Emissões de GEE associadas à eletricidade no Brasil}

O Brasil é signatário da Convenção Quadro das Nações Unidas sobre a Mudança do Clima (United Nation Framework Convention on Climate Change - UNFCCC). Por ser um país em desenvolvimento, não possuía metas de redução de emissões de GEE para o primeiro período de comprometimento estabelecido pelo Protocolo de Quioto, que se encerrou no final de 2012. Mesmo sem ter metas de redução, o país vem empenhando esforços para contribuir na mitigação do aquecimento global por meio da redução de

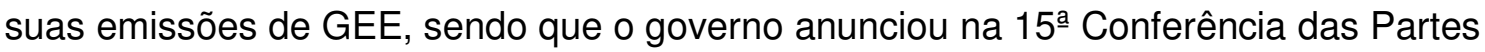
(COP-15), realizada em 2009, uma meta voluntária para reduzir, em 2020 , entre $36,1 \%$ e $38,9 \%$ das suas emissões totais projetadas para aquele ano (BRASIL, 2011a).

No setor residencial brasileiro, as emissões associadas à produção e ao consumo de eletricidade devem aumentar cerca de 27\% até 2021 em relação aos valores observados em 2011, passando de $18 \mathrm{MT} \mathrm{CO}_{2}$-eq a $23 \mathrm{MT} \mathrm{CO}$-eq (BRASIL, 2012). A garantia de disponibilidade de energia futura requer a contabilização da redução de emissões de GEE e outros benefícios do ponto de vista energético e ambiental. Para analisar o uso de fontes alternativas, como a solar fotovoltaica, faz-se necessário conhecer as emissões do SIN e de sistemas fotovoltaicos, para compreender as vantagens e limitações destas fontes na expansão do sistema e seu impacto na redução de emissões de GEE.

\subsubsection{Emissões de GEE no SIN e em sistemas fotovoltaicos}

No Brasil, as emissões de GEE associadas à geração de energia elétrica no SIN são contabilizadas e os valores são disponibilizados pelo MCTI. Os valores de fator de emissão ${ }^{21}$ de $\mathrm{CO}_{2}$ para o SIN são calculados seguindo uma metodologia específica para projetos de MDL, por meio da ferramenta Tool to calculate the emission factor for an electricity system ${ }^{22}$ (MCTI, 2014a).

De acordo com o MCTI, o fator de emissão do SIN disponibilizado para projetos de MDL combina o fator de emissão da margem de operação com o fator de emissão da margem de construção. $\mathrm{O}$ primeiro reflete a intensidade das emissões de $\mathrm{CO}_{2}$ da energia despachada na margem, ou seja das emissões da energia gerada pelas usinas em

\footnotetext{
21 Um fator de emissão é definido como a taxa média de emissão de um determinado GEE para uma dada fonte, relativa a unidades de atividade. UNFCCC Glossary. Informação disponível em: http://unfccc.int/ghg_data/online_help/definitions/items/3817.php, acessada em 20/02/2015.

22 UNFCCC, 2013.
} 
operação no SIN; já o segundo reflete a intensidade das emissões de $\mathrm{CO}_{2}$ das últimas usinas construídas (MCTI, 2014a).

Para o presente estudo, onde o intuito é contabilizar as emissões evitadas pelo uso de sistemas solares em unidades habitacionais unifamiliares, adota-se a metodologia indicada pela UNFCCC para calcular o fator de emissões em um sistema de eletricidade (UNFCCC, 2013). De acordo com esta metodologia, o cálculo de emissões evitadas por SFV deve utilizar uma combinação de $75 \%$ da margem de operação e $25 \%$ da margem de construção, sendo que para projetos pequenos, como no caso da geração fotovoltaica distribuída em unidades residenciais, é possível simplificar e adotar somente o fator de margem de operação. Os dados utilizados são os mais recentes disponíveis, e se referem às emissões associadas à operação do SIN no ano de 2013. Considerando a adoção de $100 \%$ da margem de operação, o fator médio para o referido ano foi de 0,5931 t CO$/ \mathrm{MWh}^{23}$ (MCTI, 2014b).

A análise das emissões de $\mathrm{CO}_{2}$ associadas à operação do $\mathrm{SIN}$ nos últimos quatro anos, permite identificar um aumento no fator de emissão da margem de operação associado a um uso mais intensivo das usinas termelétricas convencionais. O gráfico da Figura 2.8 demonstra a variação do fator de emissão da margem de operação e a geração térmica no SIN de 2010 a 2013.

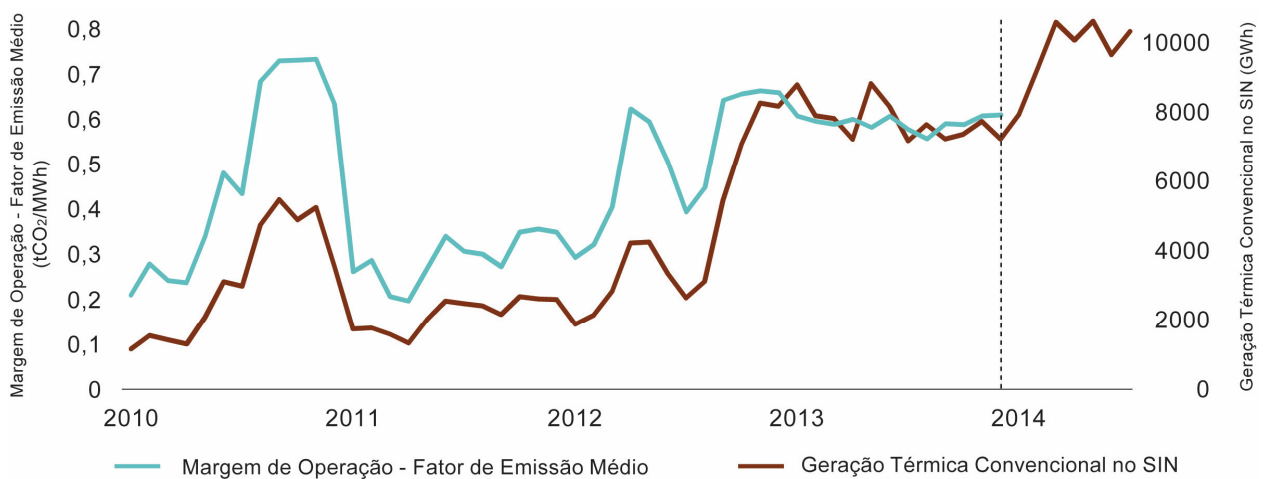

Figura 2.8: Fator de emissão no SIN para a margem de operação e geração em usinas termelétricas convencionais no SIN.

Fonte: Elaborado a partir de MCT, 2014b; ONS, 2014.

23 No caso dos valores disponibilizados pelo MCTI, a unidade de medida utilizada é a indicada pela UNFCCC, que expressa as emissões em t $\mathrm{CO}_{2} / \mathrm{MWh}$. No entanto, as emissões de GEE consideram não apenas $\mathrm{O} \mathrm{CO}_{2}$, mas também os demais gases causadores do efeito estufa. Com isso, é possível também expressar as emissões de GEE em unidades de $\mathrm{CO}_{2}$ equivalente. $\mathrm{O}$ fator de conversão de unidades físicas para $\mathrm{CO}_{2}$-eq é o Potencial de Aquecimento Global (PAG) do GEE correspondente. Por exemplo, se X g de $\mathrm{CH}_{4}$ deve ser expresso em termos de $\mathrm{CO}_{2}$-eq, esse valor $X$ é multiplicado por 21, que é o $P A G$ do $\mathrm{CH}_{4}$ ao longo de 100 anos em escala temporal (Informação disponível em: http://unfccc.int/essential_background/basic_facts_figures/items/6246.php, Acessada em 20/02/2015). Nesta dissertação, as unidades foram apresentadas conforme a fonte pesquisada, podendo constar como $\mathrm{CO}_{2}$ ou $\mathrm{Co}_{2}$-eq, mas em ambos os casos são contabilizados todos os GEE. 
Geralmente, o uso das termelétricas aumenta nos períodos de baixa precipitação e consequente redução nos níveis dos reservatórios das hidrelétricas. O uso mais intensivo das termelétricas não resulta apenas em um aumento de emissões, conforme observado no gráfico da Figura 2.8 mas também no aumento da tarifa de energia elétrica, visto que o custo da energia gerada nas termelétricas é mais alto do que o custo da energia gerada em usinas hidrelétricas.

No início do ano de 2014, a baixa precipitação ocasionou o uso intensivo de termelétricas, justamente na estação chuvosa. Em situações onde estas usinas operam no limite de sua capacidade, surgem preocupações devido à necessidade de manutenção, além dos já referidos aumentos de emissões de GEE e da tarifa de energia elétrica. Tais fatores evidenciam a necessidade de investimentos em fontes alternativas e renováveis de energia para a redução das emissões de GEE, como forma de responder ao aumento da demanda por eletricidade e à saturação do potencial hidrelétrico nas regiões com maior consumo de eletricidade no país. Sistemas como a bandeira tarifária ${ }^{24}$ e a possibilidade de contratação da geração própria de unidade consumidora $^{25}$ são medidas emergentes da crise energética e que favorecem a geração distribúida por fontes alternativas.

O valor do fator de emissões associado a SFV é obtido a partir de análises de ciclo de vida de sistemas. As emissões são associadas às etapas de manufatura e descarte destes sistemas e seus componentes. Na etapa de operação dos SFV para a geração de energia elétrica não ocorrem emissões (YUE, D., YOU, F., DARLING, S. B., 2014). Segundo o relatório especial do IPCC sobre fontes renováveis de energia e mitigação das mudanças climáticas (IPCC, 2012), o fator de emissões médio para SFV é da ordem de 0,046 $\mathrm{tCO}_{2}$-eq/MWh. Este valor indica um desempenho do ponto de vista ambiental bastante superior por parte destes sistemas se comparados ao que se observa no SIN. O valor do fator de emissões para SFV pode oscilar em função da rápida evolução desses sistemas ou dos diferentes tipos de células fotovoltaicas aplicadas. Mais detalhes quanto às emissões especificas por tecnologia são apresentados no item 3.7.2 do Capítulo 3.

\footnotetext{
${ }^{24}$ A bandeira tarifária é o sistema que sinaliza aos consumidores os custos reais da geração de energia elétrica. Este indicador passou a estar presente nas contas de energia elétrica no início de 2015 e orienta o consumidor quando ao custo da energia em função das condições de geração de eletricidade. Disponível em: <www.aneel.gov.br/area.cfm?idArea=758>. Acesso em 25/05/15.

25 A portaria MME nํㅜ 44/2015 prevê o incentivo à geração própria de unidades consumidoras, estabelecendo tarifas que cobrem custos de combustível, operação e manutenção, além da receita fixa. Disponível em: <www.aneel.gov.br/aplicacoes/audiencia/arquivo/2015/012/documento/nota_tecnica_ geracao_propria.pdf>. Acesso em 25/05/2015.
} 
A partir dos dados de emissão de GEE do SIN é possível estimar a contribuição, para a mitigação do aquecimento global, que medidas de eficiência energética e a geração de energia por fonte solar fotovoltaica podem representar quando aplicadas a unidades habitacionais unifamiliares brasileiras.

\subsection{Inserção da geração solar fotovoltaica na matriz energética brasileira}

O Brasil apresenta enorme potencial para a exploração da energia solar. A irradiação média anual na maior parte do território brasileiro varia entre 1.200 e $2.400 \mathrm{kWh} / \mathrm{m}^{2} / \mathrm{ano}$, valores que são significativamente superiores aos da maioria dos países europeus. Como ordem de grandeza do potencial energético solar, pode-se estimar que o consumo do SIN verificado em 2011 seria totalmente atendido com o recobrimento de uma área de $2.400 \mathrm{~km}^{2}$, pouco mais que a metade da área do município de Salvador, Bahia, com painéis fotovoltaicos em uma região com insolação média da ordem de $1.400 \mathrm{kWh} / \mathrm{m}^{2} /$ ano (EPE, 2012). O mapa da Figura 2.9 indica a radiação solar disponível no território brasileiro ao longo do ano.

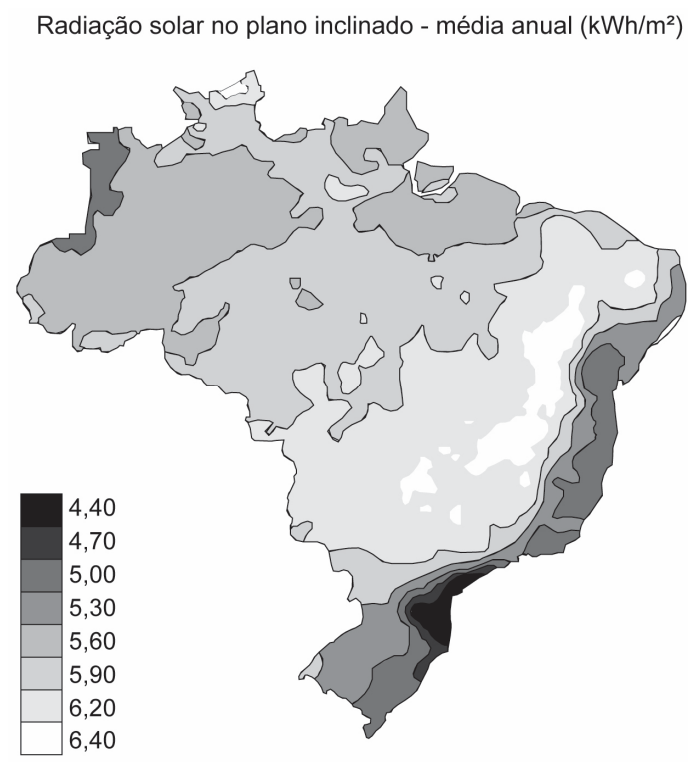

Figura 2.9: Radiação solar no Brasil para o plano inclinado.

Fonte: Adaptado de EPE, 2012; PEREIRA et al., 2006.

Por ser modular, a tecnologia solar fotovoltaica mostra-se bastante favorável como solução de geração distribuída de eletricidade, e deve ser a principal alternativa a consumidores brasileiros que queiram gerar sua própria energia no horizonte de 2050 (EPE, 2014).

No que tange à geração e distribuição de energia elétrica no Brasil, um exemplo que reforça o potencial para se adotar fontes alternativas são os recordes registrados de picos de consumo nos subsistemas Sudeste/Centro-Oeste e Sul do SIN, no mês de 
Fevereiro de 2014. Em boletim especial, o Operador Nacional do Sistema (ONS) relatou que:

"No dia 06/02/2014 ocorreram recordes de demanda instantânea nos Subsistemas SE/CO e Sul, onde as demandas máximas instantâneas atingiram respectivamente $51.261 \mathrm{MW}$ às $15 \mathrm{~h} 47 \mathrm{~m}$ e $17.971 \mathrm{MW}$ às $14 \mathrm{~h} 29 \mathrm{~m}$. A causa se deve à continuidade das altas temperaturas e ao índice de desconforto térmico nessas regiões, na hora de maior insolação" (ONS: Boletim de Carga Especial de 07/02/2014).

A Tabela 2.1 traz dados da demanda instantânea máxima, e os gráficos da Figura 2.10 demonstram os picos na demanda instantânea atingidos em Fevereiro de 2014, comparados a um histórico desde o mês de Janeiro de 2011.

\begin{tabular}{ccccc}
\hline Região & \multicolumn{2}{c}{ Máxima em $\mathbf{0 6 / 0 2 / 1 4}$} & Recorde Anterior & Data \\
\hline SE/CO & $51.261 \mathrm{MW}$ & $15 \mathrm{~h} 47$ & 51.187 & $05 / 02 / 2014$ \\
\hline SUL & $14.971 \mathrm{MV}$ & $14 \mathrm{~h} 29$ & 17.771 & $05 / 02 / 2014$ \\
\hline
\end{tabular}

Tabela 2.1: Demanda Instantânea Máxima (MW).

Fonte: ONS, 2014
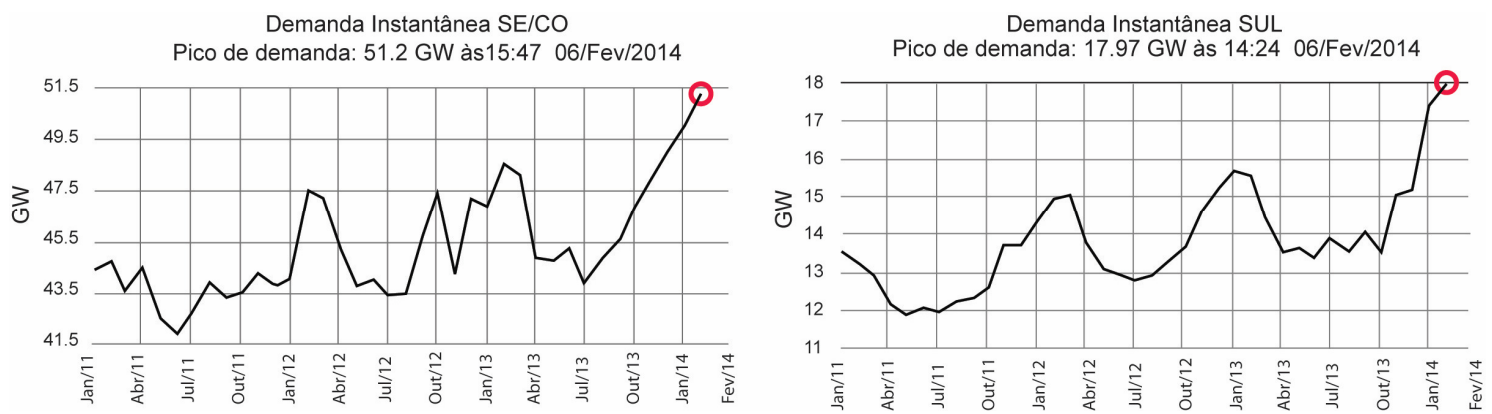

Figura 2.10: Demanda instantânea para subsistemas SE/CO e SUL.

Fonte: a partir de ONS, 2014

Observa-se que os picos recordes de consumo ocorreram em horários distintos do que se observa normalmente. No Brasil, o pico de consumo ocorre no final do dia, associado ao uso da iluminação pública, iluminação residencial, eletrodomésticos e do chuveiro elétrico nos domicílios brasileiros (CPFL, 2014)26. Esta mudança no horário de pico demonstra que sistemas fotovoltaicos poderiam contribuir no suprimento desta demanda, uma vez que o consumo máximo ocorreu durante o dia, justamente devido à intensidade da insolação e do calor neste período, ocasionando desconforto térmico no interior de edificações.

26 Companhia Paulista de Força e Luz (CPFL). Eficiência energética: Horário de pico. Disponível em: $<$ http://www.cpfl.com.br/energias-sustentaveis/eficiencia-energetica/uso-consciente/Paginas/horario-depico.aspx>. Acesso em 05/05/2014. 
Novos recordes no consumo de eletricidade no subsistema SE/CO foram registrados em Janeiro de 2015. A demanda instantânea foi de 51.864MW no dia 21 de Janeiro de 2015, entre 14h e 15h (ONS, 2015), mantendo a mudança no horário de pico associada às altas temperaturas durante o periodo da tarde. Ocorreram também cortes preventivos de energia elétrica em 11 Estados brasileiros e no Distrito Federal, para evitar desligamento de maiores proporções (BORBA, 2015). O consumo intenso de eletricidade no país levou também à necessidade de importação de energia elétrica da Argentina pela primeira vez desde 2010. Como agravante deste quadro, a baixa nos níveis dos reservatórios das hidrelétricas do subsistema SE/CO, cujo nível foi registrado em $17,34 \%$, oferece risco de racionamento por ser um valor próximo ao limite para operação das usinas, que é de 10\% (BORBA, 2015; VETTORAZZO, BORBA, 2015).

Os episódios de pico de consumo associados às altas temperaturas evidenciam a ineficiência das edificações, que muitas vezes são contruidas sem considerar as condições do clima local e, por isso, demandam alta quantidade de energia para a manutenção das condições de conforto ambiental para os ocupantes. Soma-se a esta ineficiência o fato de o ano de 2014 ter sido registrado como o mais quente desde 1880 (NOAA, 2015).

Logicamente, não seria racional investir somente no aumento da potência instalada, ainda que por meio de fonte limpa e renovável como a geração solar fotovoltaica. Ações para a um aumento na eficiência energética das edificações são também essenciais para a redução do consumo de eletricidade. No entanto, este cenário permite perceber que a fonte solar fotovoltaica se mostra bastante favorável para contribuir com estas novas situações de pico na demanda instantânea por energia no país.

\subsubsection{Legislação de apoio à geração distribuída para sistemas fotovoltaicos}

Para fomentar a geração solar fotovoltaica distribuída, são necessários mecanismos legais que amparem o consumidor que pretende investir nestes sistemas. Neste âmbito, a ANEEL aprovou a resolução № 482, de 17 de abril de 2012, que estabelece regras para a microgeração (de até $100 \mathrm{~kW}$ ) e a minigeração (entre $100 \mathrm{~kW}$ e $1 \mathrm{MW}$ ) de energia no país (ANEEL, 2012). O objetivo é viabilizar a instalação, pelos consumidores, de módulos solares fotovoltaicos em residências, comércios ou indústrias, de modo que a produção proveniente desses equipamentos gere créditos, através de um sistema de 
compensação ${ }^{27}$. Os créditos têm validade de 36 meses e não podem ser comercializados. A possibilidade de conexão à rede permite dispensar os bancos de bateria, componentes de custo elevado e que requerem manutenção (RÜTHER, 2004).

Nesta resolução foi estabelecido que as distribuidoras devem adequar seus sistemas comerciais e elaborar ou revisar normas técnicas para tratar do acesso de microgeração e minigeração distribuída, e que os montantes de energia ativa injetada na rede que não tenham sido compensados na própria unidade consumidora podem ser utilizados para compensar o consumo de outras unidades previamente cadastradas para este fim (ANEEL, 2012).

Este tipo de legislação contribui para o surgimento de iniciativas como o Projeto 50 Telhados $^{28}$, que tem por objetivo divulgar a geração distribuída por SFV. Este projeto é coordenado pelo Instituto Ideal e é executado localmente por empresas instaladoras que, em 24 meses, a partir de 2014, devem alcançar a meta de instalar 50 telhados fotovoltaicos com potência instalada de $2 \mathrm{kWp}$, ou seja, a potência de pico (ou potência máxima) obtida sob condições padrão de teste. Tais projetos estimulam também a capacitação de mão de obra para instalação e manutenção destes sistemas.

Nos Estados Unidos e em países da União Europeia, as EEZ são consideradas importantes ferramentas nas políticas energéticas e na transição das matrizes energéticas, por motivo de segurança energética e também visando à redução de emissões de GEE. Sendo assim, são criadas políticas para promover as EEZ e são estabelecidos prazos para que novas edificações sejam adaptadas aos padrões de EEZ (PACHECO, et al., 2013). Se adotadas no Brasil, ainda que em longo prazo, políticas nestes moldes poderiam contribuir para fomentar a inserção em larga escala de SFV em edificações brasileiras.

O Brasil já apresenta alguns esforços para incentivar a geração solar fotovoltaica distribuída. Entretanto, se a intenção é que os SFV tenham maior participação no SIN, é necessário criar políticas e regulamentações mais favoráveis aos SFV. Pacheco, Lamberts (2013) apontam que a impossibilidade de vender os créditos gerados, e também o prazo limitado para utilizar esses créditos podem induzir a um aumento no consumo de energia por parte das unidades consumidoras que passarem a ser também

27 Sistema no qual a energia ativa injetada por unidade consumidora com microgeração distribuída ou minigeração distribuída é cedida, por meio de empréstimo gratuito, à distribuidora local e posteriormente compensada com o consumo de energia elétrica ativa dessa mesma unidade consumidora ou de outra unidade consumidora de mesma titularidade da unidade consumidora onde os créditos foram gerados, desde que possua o mesmo Cadastro de Pessoa Física (CPF) ou Cadastro de Pessoa Jurídica (CNPJ) junto ao Ministério da Fazenda (ANEEL, 2012b).

28 http://www.americadosol.org/50telhados/ 
geradoras. Isso demonstra a necessidade de aprimorar as regulamentações nacionais quanto a este sistema de compensação, levando em conta o sistema elétrico como um todo, considerando tanto o lado da oferta quanto o lado da demanda por energia elétrica.

\subsubsection{Viabilidade econômica e mercado para sistemas fotovoltaicos no Brasil}

A possibilidade da geração distribuída conectada ao SIN implica mudanças no setor elétrico e na dinâmica do planejamento energético no Brasil, uma vez que parte da demanda deve passar a ser suprida pelos próprios consumidores que tenham interesse em adotar SFV para geração de eletricidade. Com isso, estudos vem sendo dedicados a estimar a viabilidade economica e o mercado potencial de SFV no contexto brasileiro. São exemplos as publicaçoes de EPE (2012), EPE (2014), Konzen (2014) e Montenegro (2013).

Em algumas cidades brasileiras as tarifas praticadas pelas concessionarias ${ }^{29}$ são superiores ao custo estimado para a geração fotovoltaica, considerando uma vida útil de 20 anos para o sistema, e 10 anos para os inversores (EPE, 2012). A EPE (2012) aponta, ainda, que iniciativas que criem legislações para dar suporte a instalações de sistemas fotovoltaicos são essenciais no sentido de reduzir barreiras de acesso ao sistema de distribuição por parte de pequenos geradores.

Instrumentos como a criação de linhas de financiamento para pessoas físicas e pequenos investidores também podem contribuir para facilitar o acesso a sistemas de micro e minigeração fotovoltaica, bem como a criação de fundo segurador para pessoa física e pequenos investidores que utilizarem estas linhas de financiamento. Iniciativas como desconto no imposto de renda (IR), da ordem de $30 \%$, poderiam impactar significativamente no custo nivelado da geração fotovoltaica, tornando possível uma paridade com as tarifas praticadas pela maioria das concessionárias do país. A isenção fiscal é outro mecanismo que pode ser aplicado para incentivar a instalação de sistemas fotovoltaicos para geração distribuida no país (EPE, 2012). A Tabela 2.2 resume os possíveis beneficios obtidos com os referidos mecanismos de incentivo.

\footnotetext{
${ }^{29}$ Atualmente, 62 concessionárias são responsáveis pela distribuição de energia elétrica no SIN, e as tarifas residenciais variam de $0,23 \mathrm{R} \$ / \mathrm{kWh}$ a $0,47 \mathrm{R} \$ / \mathrm{kWh}$. Disponível em: <http://www.aneel.gov.br/area.cfm?idArea=493>. Acesso em: 08/06/2014.
} 


\begin{tabular}{|c|c|c|c|c|c|}
\hline & $\begin{array}{c}\text { Potência } \\
\text { instalada } \\
(\mathrm{kWp})\end{array}$ & $\begin{array}{c}\text { Custo } \\
\text { nivelado } \\
\text { de geração } \\
\text { - Base } \\
\text { (R\$/MWh) } \\
\end{array}$ & $\begin{array}{c}\text { Financiamento } \\
\text { diferenciado } \\
(\mathbf{R} \$ / \mathrm{MWh})\end{array}$ & $\begin{array}{c}\text { Redução } \\
\text { do IR de } \\
30 \% \\
(\mathrm{R} \$ / \mathrm{MWh})\end{array}$ & $\begin{array}{c}\text { Redução de } \\
\text { impostos } \\
\text { sobre } \\
\text { equipamentos } \\
\text { (R\$/MWh) } \\
\end{array}$ \\
\hline \multirow{2}{*}{$\begin{array}{c}\text { Geração } \\
\text { Fotovoltaica }\end{array}$} & 5 & 602 & 586 & 465 & 524 \\
\hline & 10 & 541 & 526 & 418 & 470 \\
\hline $\begin{array}{l}\text { Tarifa homologada } \\
\text { ANEEL (valor médio) }\end{array}$ & & 457 & & & \\
\hline \multicolumn{2}{|c|}{$\begin{array}{c}\text { Tarifa final das distribuidoras no } \\
\text { Brasil }\end{array}$} & 240 a 709 & & & \\
\hline
\end{tabular}

Tabela 2.2: Custo da eletricidade ofertada pelas distribuidoras e da eletriciadade fotovoltaica em função dos mecanismos de incentivo fiscal e financiamento. Fonte: elaboração propria com base em EPE, 2012.

No caso da geração distribuída, por ter seu patamar de competitividade definido a partir das tarifas de distribuição de energia ao consumidor final, os sistemas solares fotovoltaicos já estão próximos à condição de viabilidade econômica para alguns pontos da rede elétrica. Para viabilizar uma redução mais significativa dos custos de produção de sistemas fotovoltaicos dentro no país, com ganhos em escala, é necessário estimular um maior desenvolvimento do mercado para a energia solar (EPE, 2012).

Complementarmente, é importante notar que algumas estratégias adotadas pelo governo, como a Medida Provisória 579 de $2012^{30}$, prevendo regras para redução de $20 \%$, em média, das tarifas de energia elétrica, podem retardar a viabilidade econômica de sistemas fotovoltaicos no país ${ }^{31}$. De fato, se observadas as tarifas residenciais vigentes homologadas pela ANEEL, com vigência válida até Abril de 2015, o valor médio das tarifas de 62 concessionarias do país fica em 0,321 R \$/kWh (ANEEL, 2014) ) $^{32}$, valor inferior aos $0,457 \mathrm{R} \$ / \mathrm{kWh}$ considerados como o valor médio da tarifa homologada pela ANEEL utilizado nas projeções da EPE (2012).

No horizonte de 2050, os SFV para o setor residencial devem ter uma redução da ordem de $70 \%$ nos custos, sendo que por volta do ano 2022 devem atingir paridade tarifária em praticamente todo o país (EPE, 2014). O gráfico da Figura 2.11 demonstra esta perspectiva de decréscimo.

\footnotetext{
30 http://www2.camara.leg.br/legin/fed/medpro/2012/medidaprovisoria-579-11-setembro-2012-774153publicacaooriginal-137560-pe.html

31 Esta medida é apontada, especificamente, como um exemplo de como decisões políticas acabam impactando na inserção de fontes alternativas na matriz energética brasileira.

$32 \mathrm{http}: / /$ www.aneel.gov.br/area.cfm?idArea $=493$
} 


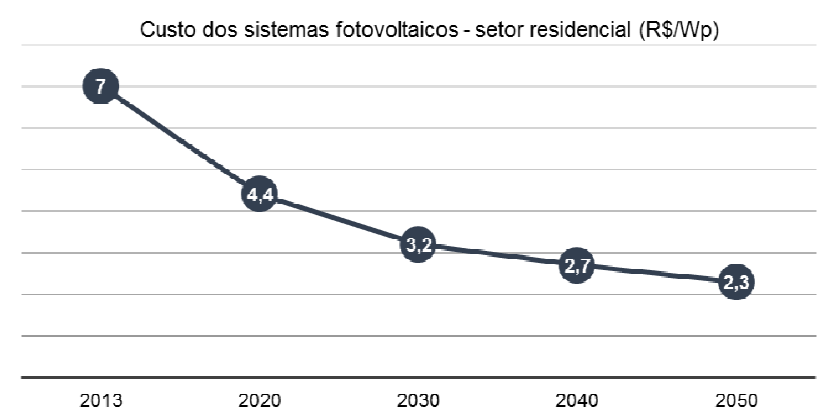

Figura 2.11: Perspectiva de redução de custo dos sistemas fotovoltaicos para o setor residencial. Fonte: A partir de EPE, 2014.

Estudo da EPE (2014) caracterizou o mercado potencial fotovoltaico residencial no horizonte de 2050. Para tanto, tomou-se como base a projeção do número de domicílios, a evolução da demanda elétrica e sua distribuição por faixas de consumo. Nesta projeção foi considerada a manutenção do sistema de compensação atual, o que implica uma limitação na capacidade instalada, ou potência, do SFV por faixa de consumo para as unidades consumidoras, visto que o dimensionamento de sistema com capacidade ociosa resulta em desperdício de parte da energia gerada e não traz vantagens econômicas. Com isso, foram determinados valores de potência típica por faixa de consumo, conforme demonstrado na Tabela 2.3.

\begin{tabular}{cc}
\hline $\begin{array}{c}\text { Faixa de Consumo } \\
\text { (kWh/mês) }\end{array}$ & $\begin{array}{c}\text { Potência Típica } \\
\text { (kWp) }\end{array}$ \\
\hline $100-200$ & 1 \\
\hline $200-300$ & 1,5 \\
\hline $300-400$ & 2 \\
\hline $400-500$ & 3 \\
\hline $500-1000$ & 4 \\
\hline$>1000$ & 10 \\
\hline
\end{tabular}

Tabela 2.3: Potência típica por faixa de consumo Fonte: EPE, 2014.

Konzen (2014) aponta que as regiões Sul e Sudeste apresentam maior potencial enquanto mercado para SFV devido à densidade populacional e maior renda. Cenários considerando desconto no $\mathrm{IR}^{33}$, isenção fiscal dos módulos fotovoltaicos ${ }^{34}$, a não tributação da compensação ${ }^{35}$, e a aplicação do sistema virtual net metering ${ }^{36}$ podem

\footnotetext{
33 Redução de $30 \%$ nos primeiros anos, com diminuição gradativa ao longo do horizonte de projeção.

34 Isenção de IR, PIS e CONFIS totalizando 17,5\%.

35 Considera que não haveria incidência de impostos sobre a energia injetada na rede.

36 "Por esse modelo é realizada uma grande instalação com diversos donos, ou sócios, que possuem cotas do empreendimento e têm direito à parte da geração de energia produzida. Além da redução de custos proporcionada pelos ganhos de escala, este modelo de negócio possibilita que consumidores que não tenham condições de instalar um sistema fotovoltaico em sua residência ou com perspectiva de mudança, possam usufruir da geração alheia ao seu domicílio, sendo abatida diretamente na sua fatura" (KOZEN, 2014, p. 30).
} 
contribuir significativamente no aumento do mercado consumidor potencial para o setor residencial. No cenário mais otimista, que agrega todos estes mecanismos para redução de custos de SFV, estima-se que até 2023 o país poderia contar com 1,033 milhões de domicílios com SFV, totalizando uma capacidade instalada de $3100 \mathrm{MWp}$, valor quase 10 vezes superior ao que seria observado em um cenário de referência, baseado na manutenção da regulação atual e sem incentivos econômicos, no qual estima-se que a potência de SFV poderia chegar somente a $330 \mathrm{MWp}$.

Os estudos apresentados demonstram que as possibilidades para incentivar a geração distribuída por meio de SFV são bastante amplas e podem impactar de forma determinante a viabilidade econômica e a adoção em maior escala destes sistemas por parte do consumidor residencial brasileiro. A maior difusão de EEZ e a maior conscientização ambiental por parte do consumidor brasileiro são também fatores que podem impactar positivamente no aumento da adoção destes sistemas (EPE, 2014).

\subsubsection{Projetos de Mecanismo de Desenvolvimento Limpo - MDL}

Para estimar as emissões de GEE que podem ser evitadas pelo uso de sistemas solares para geração de energia, bem como por meio da adoção de medidas de eficiência energética, são adotadas metodologias e ferramentas específicas para projetos de MDL. Portanto, faz-se necessário abordar alguns conceitos básicos do MDL. Uma vez contabilizadas emissões de GEE evitadas, poderiam ser obtidos créditos de Redução Certificada de Emissão (RCE), por meio do MDL (MICHAELOWA, 2007).

\footnotetext{
"Uma unidade de RCE é igual a uma tonelada de dióxido de carbono equivalente calculada de acordo com o Potencial de Aquecimento Global (Global Warming Potential - GWP). O GWP serve para comparar e somar as quantidades dos diversos GEE em termos de dióxido de carbono equivalente" (FRONDIZI, 2009, p. 23).
}

O MDL foi estabelecido pelo Protocolo de Quito. Trata-se de um mecanismo que possibilita que os países industrializados que precisam cumprir metas quantificadas de redução de emissões de GEE (partes no Anexo-1 do protocolo) possam adquirir RCE geradas por projetos implementados em países em desenvolvimento (partes nãoAnexo-1 do protocolo). Isso possibilita aos países industrializados o alcance de parte de suas metas de redução de GEE e contribui para o desenvolvimento sustentável dos países anfitriões (UNITED NATIONS, 1998). 
Para um melhor entendimento sobre a aplicação do MDL, é necessário abordar os conceitos de 'linha de base' e 'adicionalidade'. A linha de base de um projeto de MDL é "o cenário que representa, de forma razoável, as emissões antrópicas por fontes ou as remoções antrópicas por sumidouros de gases de efeito estufa que ocorreriam na ausência do projeto proposto" (CQNUMC, 2002). Quanto à adicionalidade, "uma atividade de projeto MDL é adicional se as emissões antrópicas de GEE por fontes são reduzidas a níveis inferiores aos que teriam ocorrido na ausência da atividade do projeto de MDL registrada" (UNFCCC, 2006).

Para estimar a redução de emissões de GEE e outros benefícios do ponto de vista energético e ambiental, considera-se a implantação de Casas Solares, como alternativa a unidades habitacionais unifamiliares comuns e atendidas pelo SIN, que seriam a linha de base. Verificando-se a adicionalidade por meio de Casas Solares, poderiam ser obtidas RCEs. Créditos de carbono podem ser obtidos também em mercados voluntários de carbono, onde Reduções Verificadas de Emissão (RVEs) são negociadas por empresas que não possuem metas de redução de emissões pelo Protocolo de Quioto, motivo pelo qual tais negociações são consideradas voluntárias (INSTITUTO CARBONO BRASIL, 2014 ${ }^{37}$ ). Estas estratégias podem vir a ser uma forma de incentivo econômico para a instalação de sistemas solares, e também para a adoção de medidas de eficiência energética no setor residencial brasileiro.

O foco desta dissertação não é contabilizar o impacto que estes créditos poderiam ter na viabilidade econômica de sistemas solares no Brasil. No entanto, sendo os projetos de MDL ações locais que proporcionam um impacto global no sentido de contribuir para a mitigação das mudanças climáticas, fomentar o mercado de carbono mundial pode ser uma maneira de estimular uma maior penetração de tecnologias limpas nos países em desenvolvimento, dentre elas as tecnologias solares para geração de energia.

\subsection{Consumo de eletricidade pelo setor residencial brasileiro}

No Brasil, o setor residencial é responsável por cerca de $26 \%$ do consumo de energia elétrica. A evolução do consumo residencial de energia resulta, basicamente, do crescimento do número de domicílios associado ao aumento populacional, da evolução da posse e uso dos equipamentos eletrodomésticos, da potência de consumo de cada equipamento e da evolução dos índices de eficiência energética dos mesmos (BRASIL,

\footnotetext{
${ }^{37} \mathrm{http}: / /$ www.institutocarbonobrasil.org.br/mercado_de_carbono/mercado_voluntario
} 
2012). No setor residencial destacam-se ainda o uso do gás liquefeito de petróleo (GLP) e da lenha, sendo esses destinados principalmente aos serviços de cocção de alimentos e aquecimento de água para banho. O gráfico da Figura 2.12 ilustra o consumo de energia elétrica por setor no país.

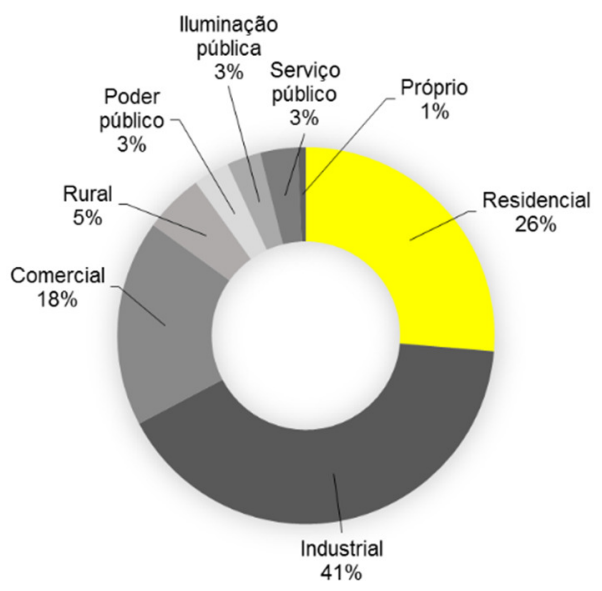

Figura 2.12: Participação no consumo de energia elétrica por setor no Brasil em 2012. Fonte: EPE, 2013a.

Embora seja a segunda classe de maior consumo de eletricidade no país, o consumo médio mensal nos domicílios brasileiro é bastante inferior ao de países desenvolvidos. Uma residência norte-americana, por exemplo, consome em média $958 \mathrm{kWh} / \mathrm{mês} \mathrm{(EIA,}$ 2011) e o consumo médio das residências na Espanha é da ordem de $876 \mathrm{kWh} / \mathrm{mês}$ (IDEA, 2011). No Brasil, o consumo médio é de 165 kWh/mês (EPE, 2014). Cada país apresenta características específicas que influem no consumo de eletricidade, como o rigor do clima, o acesso a bens de consumo, além de aspectos culturais e econômicos.

No Brasil, o aumento da renda per capita associado à tendência de uma redução contínua na desigualdade social deve contribuir para uma mudança no padrão de consumo de eletricidade no país (EPE, 2014). O número de domicílios deve aumentar em cerca de 40 milhões de unidades no horizonte de 2050, devido ao suprimento do déficit habitacional existente e ao aumento da população, passando de 63 milhões de domicílios em 2013 para 98 milhões em 2050. A associação destes fatores irá contribuir para que o consumo de eletricidade per capita passe de $500 \mathrm{kWh} /$ habitante/ano para 1570 kWh/habitante/ano em 2050 (EPE, 2014), chegando a um patamar próximo à média dos países da União Europeia, conforme demonstra o gráfico da Figura 2.13. 


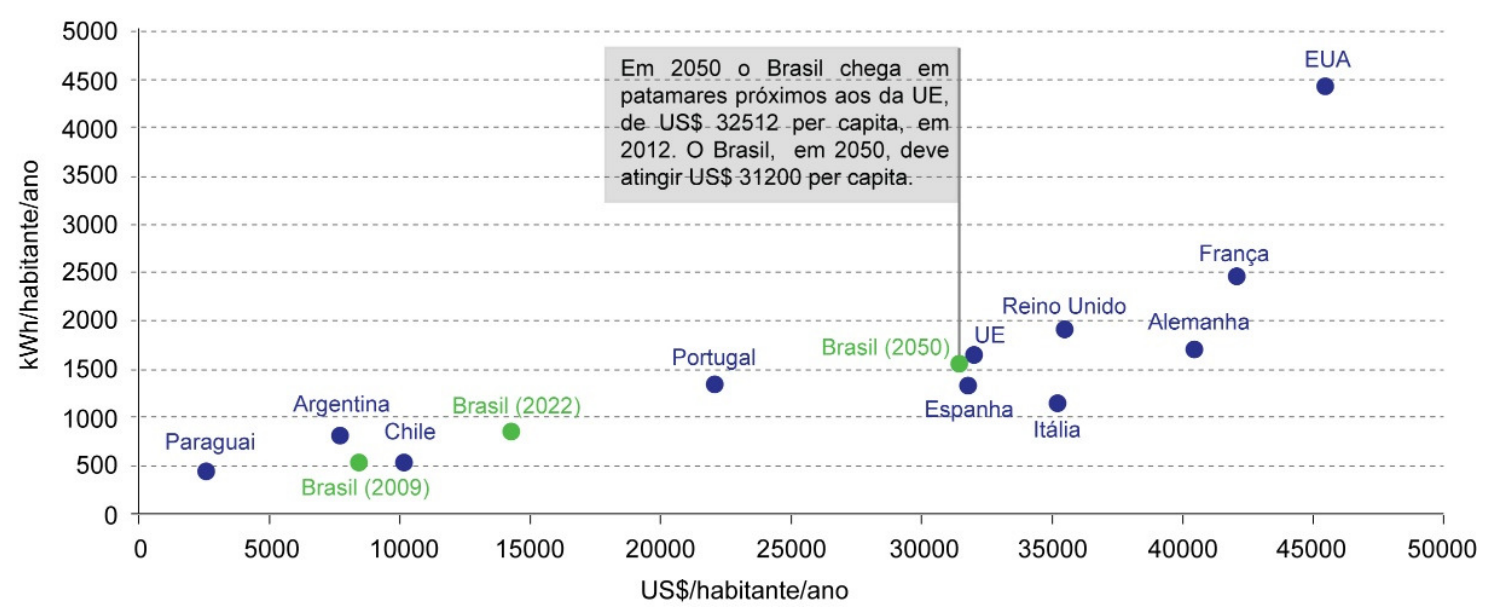

Figura 2.13: Comparação entre consumo residencial de eletricidade e renda per capita em diferentes países.

Fonte: A partir de EPE, 2014

Cerca de dois terços do total dos domicílios brasileiros consomem até $200 \mathrm{kWh} / \mathrm{mês}$ (PROCEL, 2007). No entanto, com o aumento de renda, a posse média de equipamentos também tende a aumentar, implicando uma alteração no percentual de consumidores por faixa de consumo. Sendo assim, considerando que a distribuição de consumidores por faixa de consumo não se mantenha na mesma proporção do ano base, o consumo médio mensal por domicílio deve chegar a 284 kWh em 2050 (EPE, 2014). O gráfico da Figura 2.14 indica os deslocamentos de população por faixa de consumo projetados para o horizonte de 2050.

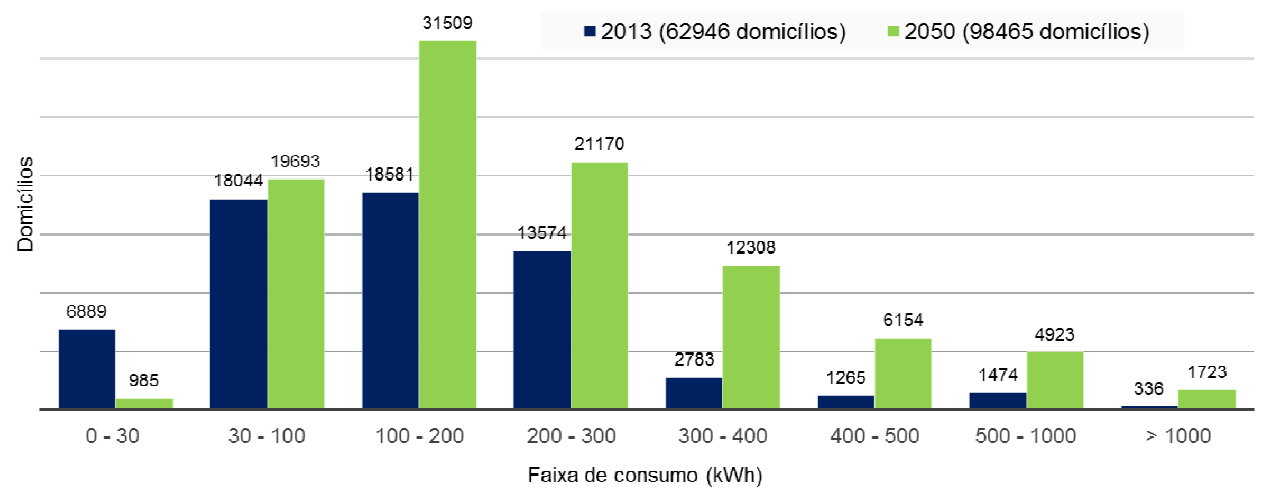

Figura 2.14: Distribuição do consumo de domicílios por faixa. Fonte: EPE, 2014.

Estima-se que, entre 2013 e 2050, o consumo de eletricidade do setor residencial brasileiro aumente em 212 TWh, passando de 124 TWh para 336 TWh (EPE, 2014). O aumento no número de domicílios é o principal fator para o aumento do consumo de eletricidade por parte do setor. A potência de alguns equipamentos irá diminuir, mas a tendência é que a posse e o uso dos mesmos aumentem. O gráfico da Figura 2.15 indica 
os principais fatores associados a este aumento e a projeção de incremento no consumo por fator.

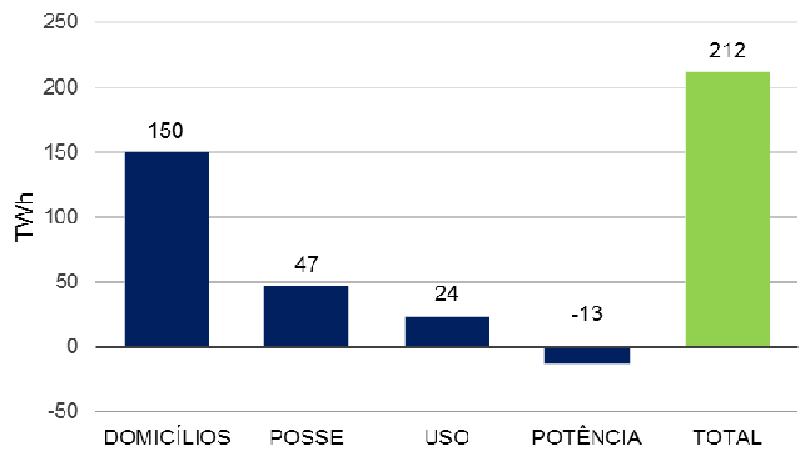

Figura 2.15: Consumo de eletricidade da rede por classe (GWh). Fonte: EPE, 2014.

\subsubsection{Equipamentos e consumo de energia nos domicílios brasileiros}

Com relação ao consumo de eletricidade por eletrodomésticos, equipamentos e sistemas nas residências brasileiras, o chuveiro, a geladeira, o ar-condicionado e a iluminação artificial são responsáveis pelas maiores parcelas do consumo de energia elétrica no setor residencial no Brasil (PROCEL, 2007), como mostra o gráfico da Figura 2.16. Para esta dissertação, o enfoque é dado ao consumo associado à provisão do conforto ambiental e ao aquecimento de água, visto que estes usos finais são diretamente influenciados pelo aproveitamento do sol na arquitetura, conforme demonstrado no Capítulo 3.

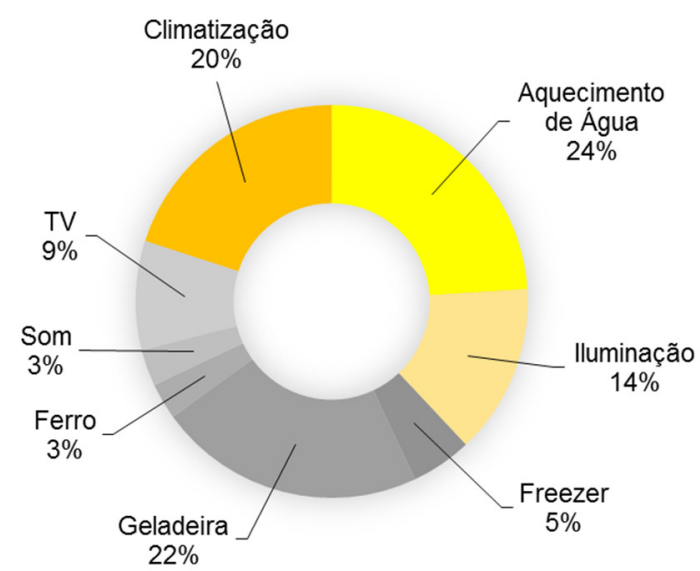

Figura 2.16: Participação dos equipamentos no consumo residencial brasileiro. Fonte: Própria com base em PROCEL, 2007.

Considerando os fatores expostos anteriormente, como o incremento no número de novas ligações à rede, o aumento da renda das famílias e sua melhor distribuição, o estoque desses equipamentos nas residências irá aumentar (BRASIL, 2012). Na Tabela 
2.4 é possível observar a evolução na posse de equipamentos por domicílio brasileiro no horizonte de 2050.

\begin{tabular}{lrr}
\hline Equipamento & $\mathbf{2 0 1 3}$ & $\mathbf{2 0 5 0}$ \\
\hline Ar Condicionado & 0,23 & 0,65 \\
\hline Lâmpada & 8,25 & 12,13 \\
\hline Chuveiro & 0,7 & 0,32 \\
\hline Televisão & 1,61 & 2,32 \\
\hline Máquina de Lavar & 0,68 & 0,94 \\
\hline Freezer & 0,18 & 0,12 \\
\hline Geladeira & 1,03 & 1,03 \\
\hline
\end{tabular}

Tabela 2.4: Posse média de equipamentos nos domicílios brasileiros (unidades de equipamento por domicílio).

Fonte: EPE, 2014

No horizonte de 2050, os chuveiros elétricos para aquecimento de água devem perder participação, já que parte deste mercado passará a ser atendida por aquecedores a gás natural, e também devido a uma maior penetração dos SAS (BRASIL, 2012). O gráfico da Figura 2.17 ilustra a evolução na participação por fonte no aquecimento de água nos domicílios brasileiros, no horizonte de 2050.

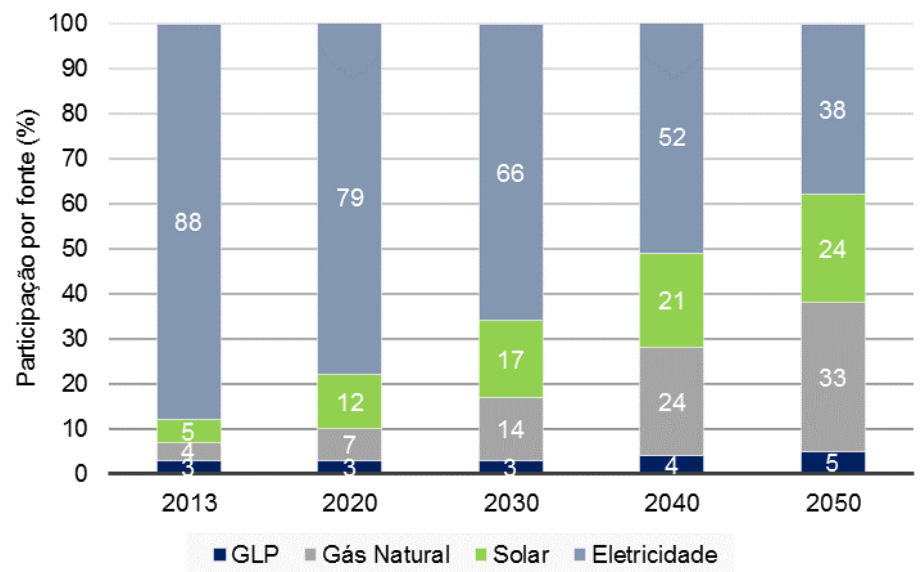

Figura 2.17: Participação das fontes no aquecimento de água para banho nos domicílios brasileiros. Fonte: EPE, 2014.

Entretanto, o chuveiro elétrico segue como principal sistema para aquecimento de água nessa projeção. A maior disponibilidade de gás natural contribui para o aumento da participação deste energético no aquecimento de água. Os coletores solares devem aumentar gradativamente sua participação, impulsionados no curto prazo por programas como o Minha Casa Minha Vida (MCMV) ${ }^{38}$, e também pelo Programa de Eficiência Energética da ANEEL ${ }^{39}$. O gráfico da Figura 2.18 demonstra as projeções de penetração de coletores solares no setor residencial brasileiro.

\footnotetext{
38 http://www.caixa.gov.br/habitacao/mcmv/

39 http://www.aneel.gov.br/biblioteca/downloads/livros/revista_pee_ago_01.pdf
} 


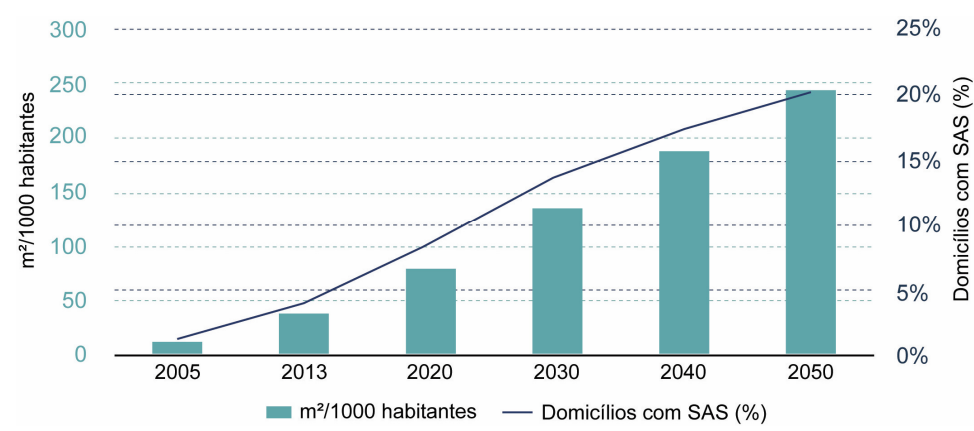

Figura 2.18: Indicadores e aumento do uso de coletores solares nos domicílios brasileiros. Fonte: EPE, 2014

Para incentivar a adoção de SAS no mercado brasileiro, foram criadas iniciativas como o programa Cidades Solares ${ }^{40}$, que tem por objetivo principal promover o uso de aquecedores solares de água no Brasil. Além disso, a Lei Solar ${ }^{41}$ da cidade de São Paulo determina que novas edificações devem ser providas de SAS para o aquecimento de água, e que estes sistemas devem ser dimensionados para atender, no mínimo, a $40 \%$ da demanda anual por água quente. Esta legislação se aplica a edificações unifamiliares ou multifamiliares e que possuem até três banheiros por unidade habitacional.

\subsubsection{Medidas de eficiência energética para o setor residencial}

A adoção de medidas de eficiência energética para o setor residencial pode impactar significativamente a redução do consumo de eletricidade no Brasil, visto que o setor é responsável por cerca de um quarto do consumo de eletricidade no país. A eficiência energética pode ser obtida, basicamente, de duas formas, com o progresso tendencial ou com o progresso induzido.

No progresso tendencial considera-se que o montante de energia conservado em um cenário futuro é reflexo da ação natural de reposição tecnológica ao fim da vida útil de equipamentos, e também da continuidade de políticas, programas e ações para conservação de energia já em prática no país (BRASIL, 2011b; EPE, 2014). O progresso induzido considera a implementação de novas políticas, programas e ações destinados a impulsionar a adoção de medidas de eficiência energética. São necessárias ações adicionais a serem adotadas para fomentar as medidas de economia de energia, relacionadas fundamentalmente a políticas públicas em estágio de estudo para implantação no campo da eficiência energética, compreendendo avanços regulatórios,

\footnotetext{
40 www.cidadessolares.org.br

${ }^{41}$ Lei no 14.459, de 3 de julho de 2007, da cidade de São Paulo. Disponível em: < www3.prefeitura.sp.gov.br/cadlem/secretarias/negócios_juridicos/cadlem/integra.asp?alt=04072007L\% 20144590000 >. Acesso em 04/05/2015.
} 
incentivos fiscais, restrições legais, entre outros (BRASIL, 2011b; EPE, 2014).

Nas projeções de ganhos em eficiência energética pelo setor residencial, progresso tendencial e induzido são combinados. Entretanto, há uma predominância do progresso tendencial a curto e em médio prazo, visto que novas políticas demandam tempo para maturação e penetração. Sendo assim, são considerados basicamente a posse e uso de equipamentos, e a estimativa de evolução tecnológica e redução no consumo de energia por parte dos mesmos (EPE, 2014). As projeções de ganhos em eficiência energética por serviço são indicadas na Tabela 2.5 .

\begin{tabular}{lcccc}
\hline Serviço Energético & $\mathbf{2 0 2 0}$ & $\mathbf{2 0 3 0}$ & $\mathbf{2 0 4 0}$ & $\mathbf{2 0 5 0}$ \\
\hline Climatização & $6,50 \%$ & $15,70 \%$ & $25 \%$ & $34,30 \%$ \\
\hline Iluminação & $1,10 \%$ & $2,70 \%$ & $4,30 \%$ & $5,80 \%$ \\
\hline Aquecimento de Água & $1,10 \%$ & $2,60 \%$ & $4,10 \%$ & $5,70 \%$ \\
\hline Entretenimento & $7,50 \%$ & $18,20 \%$ & $28,80 \%$ & $39,50 \%$ \\
\hline Cocção & $0,10 \%$ & $0,50 \%$ & $0,40 \%$ & $0,50 \%$ \\
\hline Refrigeração & $0,60 \%$ & $1,40 \%$ & $2,20 \%$ & $3 \%$ \\
\hline Outros serviços & $2,10 \%$ & $5,10 \%$ & $8,20 \%$ & $11,20 \%$ \\
\hline
\end{tabular}

Tabela 2.5: Ganhos em eficiência energética por tipologia de serviço para o setor residencial (ano base 2013).

Fonte: EPE, 2014.

No entanto, muitas vezes os equipamentos descartados/usados são adquiridos por famílias de mais baixa renda, e seguem contribuindo de forma ineficiente para 0 consumo de eletricidade do setor residencial. Em casos específicos, como a regulamentação para retirar paulatinamente do mercado as lâmpadas incandescentes até $2016^{42}$, é possível estimar mais precisamente a redução no consumo devido a sua substituição por outras mais econômicas.

Nestas projeções, considerou-se que a busca por maior conforto levaria as famílias a adquirir equipamentos com maior potência, aumentando a demanda por eletricidade. Da perspectiva da eficiência energética, admitiu-se que a qualidade dos serviços energéticos aumentará mais rapidamente do que a potência de equipamentos para gerar tal serviço (EPE, 2014). Sendo assim, em alguns casos, um mesmo serviço poderá ser obtido com um menor dispêndio de energia. No entanto, mudanças na posse de equipamentos e hábitos de uso, associadas também à redução da demanda reprimida no país, devem contribuir para um aumento no consumo de energia pelo setor. O gráfico da Figura 2.19 permite visualizar estes fenômenos, por meio da comparação

42 Portaria interministerial no 1.007, de 31 de dezembro de 2010. Disponível em: <http://www.mme.gov.br/mme/galerias/arquivos/legislacao/portaria_interminestral/Portaria_MME-MCTMDIC_n_1.007-2010.pdf>. Acesso em: 10/10/2013. 
entre o efeito da potência no consumo total por serviço com efeito líquido no consumo por uso.

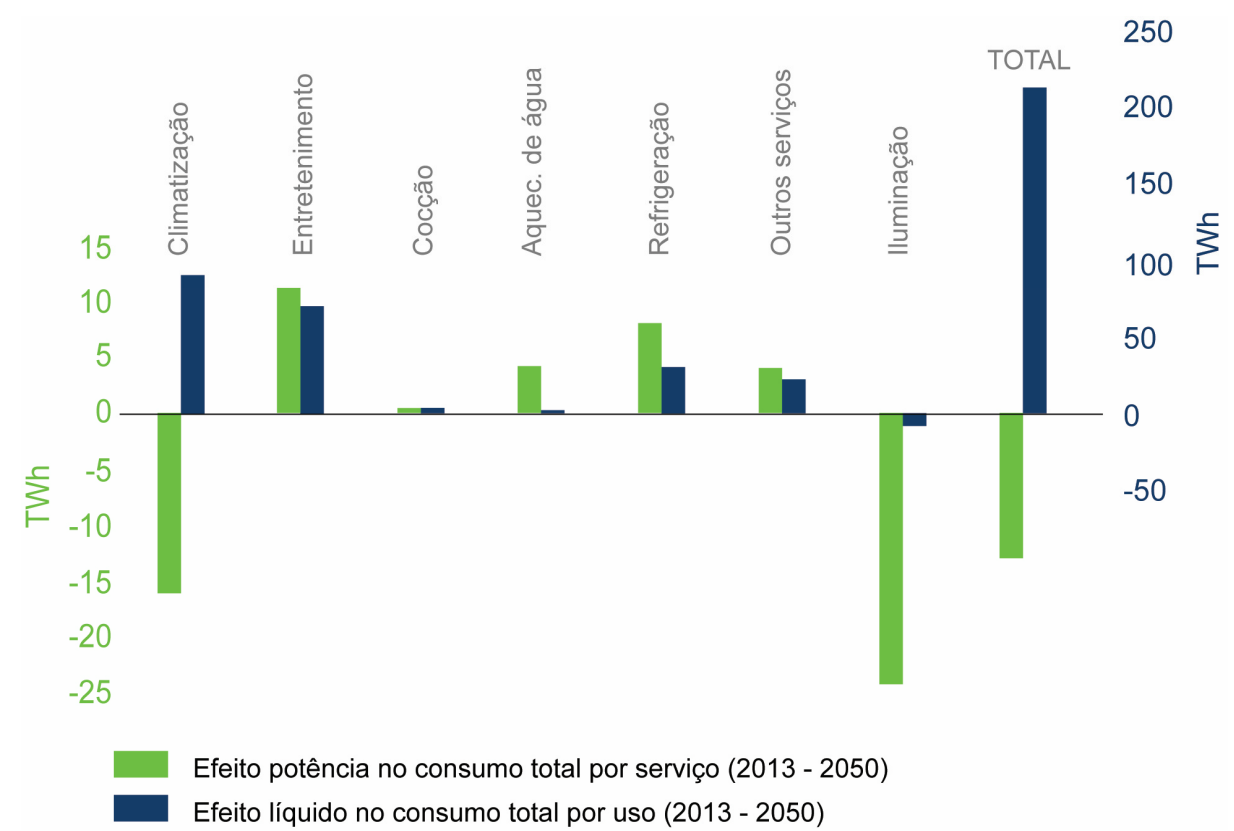

Figura 2.19: Efeito potência no consumo total por serviço e efeito líquido no consumo total por uso (2013 2050).

Fonte: A partir de EPE, 2014.

Considerando os fatores mencionados, a tendência aponta para um aumento considerável no consumo de energia por parte do setor residencial no horizonte de 2050. A climatização deverá responder pela maior parcela de consumo no setor. Entretanto, estima-se que as medidas de eficiência energética consideradas podem contribuir para uma conservação de energia da ordem de $19,5 \%$ no horizonte do estudo. O gráfico da Figura 2.20 resume os dados de consumo por tipo de serviço e potencial de conservação de energia para o setor.

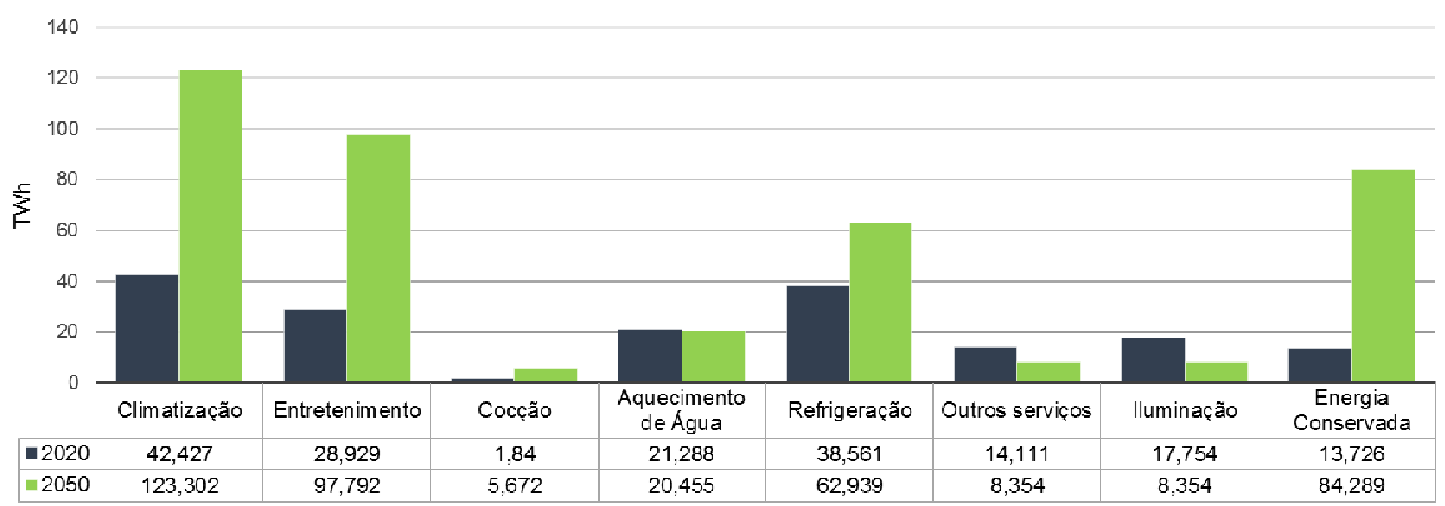

Figura 2.20: Consumo de eletricidade por serviço energético e energia conservada para o setor residencial brasileiro nos horizontes de 2020 e 2050.

Fonte: A partir de EPE, 2014.

As mudanças na posse de equipamentos e hábitos de uso, o deslocamento da população entre faixas de consumo, a penetração de novas tecnologias e substituição 
gradativa de algumas fontes irão impactar a participação de energéticos para atender à demanda por eletricidade do setor residencial. A participação da energia elétrica e do gás natural deve aumentar, enquanto fontes como lenha, carvão vegetal e gás liquefeito de petróleo (GLP) perderão importância. Os gráficos da Figura 2.21 mostram a participação por fonte em 2013 e a projeção para 2050.
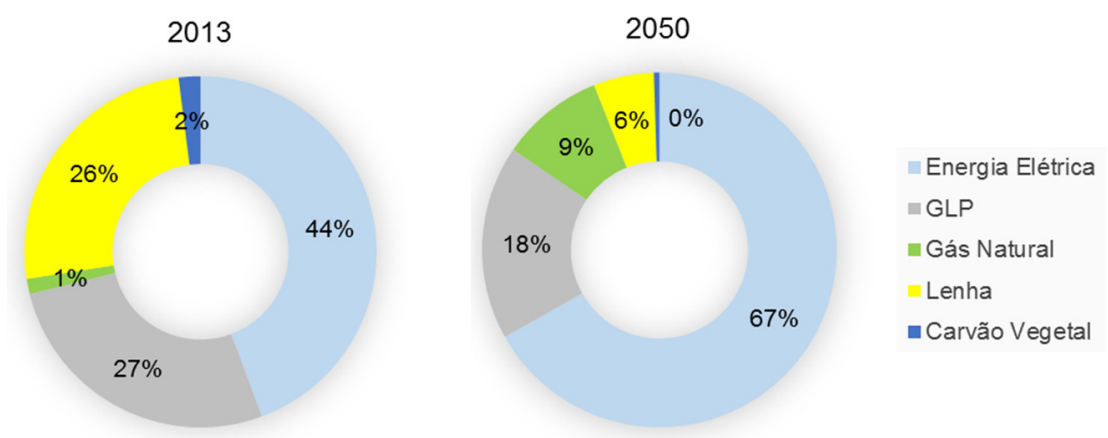

Figura 2.21: Consumo final por energético para o setor residencial em 2013 e 2050.

Fonte: EPE, 2014

Tendo em vista que a eletricidade deve aumentar sua participação, e que a climatização é o serviço que deve responder pela maior parcela de consumo de eletricidade no setor residencial, faz-se oportuno atentar para exemplos de outros países, onde medidas para o progresso induzido foram adotadas e impactaram positivamente na conservação de energia. Nos Estados Unidos, observou-se que as casas construídas a partir do ano 2000, e que somavam 14\% de todas as moradias ocupadas nos EUA, no ano de 2009 consumiam, em média, $21 \%$ menos energia para aquecimento do ambiente interno do que as unidades mais antigas, conforme indicado no gráfico da Figura 2.22. Esta redução no consumo é atribuída principalmente ao aumento da eficiência nos equipamentos de aquecimento e à melhora no desempenho das vedações dos edifícios, construídos para atender a códigos de consumo de energia mais exigentes (EIA, 2012).

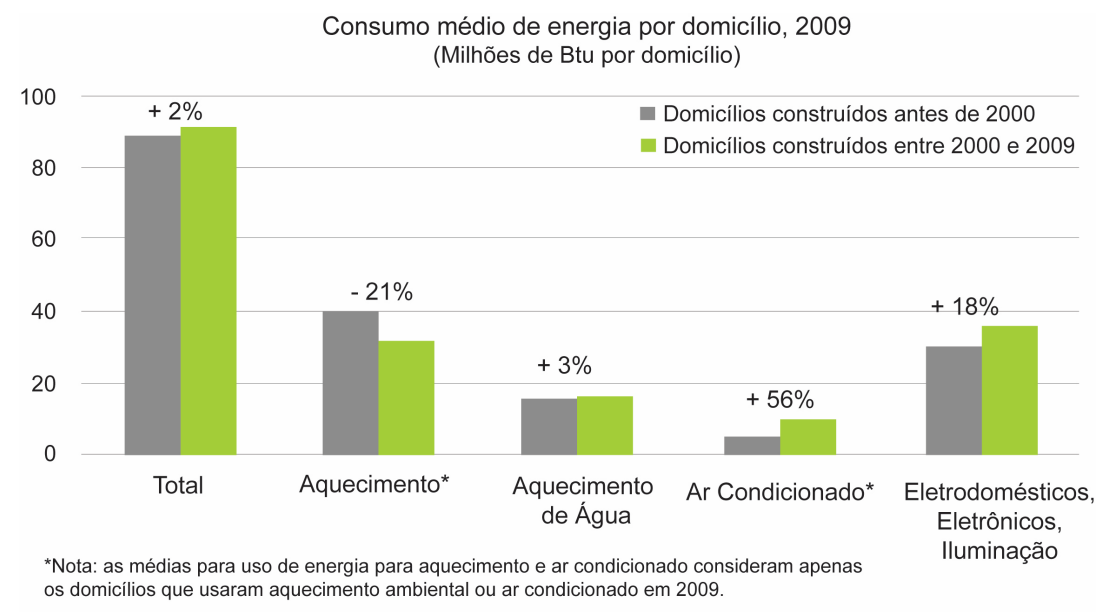

Figura 2.22: Consumo médio doméstico de energia elétrica por uso final. Fonte: A partir de EIA, 2012. 
Este exemplo demonstra que, complementarmente à previsão de aumento na eficiência de equipamentos, em edificações residenciais, a eficiência energética pode ser potencializada por meio do progresso induzido ${ }^{43}$. As características construtivas das edificações e os hábitos de uso dos ocupantes também desempenham papel fundamental para um consumo de energia elétrica mais eficiente. No projeto Casa Eficiente, estima-se que os hábitos dos ocupantes associados a equipamentos e a um projeto eficiente podem resultar em uma economia de até $83 \%$ no consumo de energia elétrica em uma residência (LAMBERTS et al., 2010). Este fato evidencia que a contribuição das edificações residenciais na redução do consumo de energia elétrica pode ser potencializada por projetos eficientes.

No âmbito dos mecanismos legais voltados à eficiência energética pode ser citada a Lei 10.295/2001, conhecida como Lei da Eficiência Energética ${ }^{44}$ que, dentre outros objetivos, visa o desenvolvimento de mecanismos para determinar os níveis mínimos de eficiência energética em edificações (BRASIL, 2011b). Neste sentido, alguns avanços já foram feitos, a exemplo do Programa Nacional de Conservação de Energia Elétrica voltado às edificações (PROCEL Edifica) que, especificamente na área de edificações residenciais, busca fomentar estudos, pesquisas e ações para promover melhoria das habitações; incluir parâmetros para a orientação de eficiência energética em edificações nos Códigos de Obras, Planos Diretores e Caderno de Encargos (BRASIL, 2011b).

Dentro do PROCEL Edifica, destaca-se o Programa Brasileiro de Etiquetagem de Edificações (PBE), para o qual foram desenvolvidos os Requisitos Técnicos da Qualidade do Nível de Eficiência Energética de Edifícios Comerciais, de Serviços e Públicos (RTQ-C) e o Regulamento Técnico da Qualidade do Nível de Eficiência Energética de Edificações Residenciais (RTQ-R) ${ }^{45}$. Em Junho de 2014, na publicação do Diário Oficial da União pela Secretaria de Logística e Tecnologia ${ }^{46}$, ficou determinado o uso obrigatório da Etiqueta Nacional de Conservação de Energia (ENCE) em edifícios públicos federais novos ou que recebam retrofit (ou reforma), para melhoria do desempenho energético. A etiquetagem de edifícios residenciais ainda é voluntária, mas dentro deste programa é possível buscar orientações sobre como obter maior eficiência

\footnotetext{
${ }^{43}$ Que pode acontecer, por exemplo, pela criação certificações ambientais e legislações mais rígidas quanto à eficiência energética nas edificações.

44 Disponível em: <https://www.planalto.gov.br/ccivil_03/leis/leis_2001/110295.htm>. Acesso em: 02/06/2013.

${ }^{45}$ PROCEL Edifica. Disponível em: <http://www.procelinfo.com.br/main.asp?View=\{89E211C6-61C2-499AA791-DACD33A348F3\}>. Acesso em: 14/05/2014.

46 Diário Oficial da União, Seção 1, № 106, quinta-feira, 5 de junho de 2014. Disponível em: $<$ http://pesquisa.in.gov.br/imprensa/jsp/visualiza/index.jsp?data=05/06/2014\&jornal=1 \&pagina=102\&totalA rquivos=164>. Acesso em: 10/09/2014.
} 
no consumo de energia destas edificações.

No Brasil, destacam-se ainda a já referia legislação para o banimento de lâmpadas incandescentes, e o programa MCMV no que diz respeito às metas de instalação de SAS. No entanto, para que a eficiência energética nas edificações seja intensificada, é necessário contar com instrumentos políticos, regulamentações, instrumentos fiscais, bem como incentivos econômicos (subsídios) e ações voluntárias (UNEP, 2011). Para tanto, é necessário que os gestores públicos façam um balanço a fim de determinar a combinação mais apropriada entre estes diferentes mecanismos, visando potencializar a eficiência energética dentro das possibilidades do contexto nacional.

\subsection{Considerações sobre o capítulo}

Nesse capitulo foi evidenciada a necessidade de expansão do SIN, e o quanto a fonte solar ainda é inexpressiva nas projeções realizadas para esta expansão. No entanto, a possibilidade de conexão de SFV à rede sugere uma mudança na dinâmica de geração de energia no SIN. A fonte solar apresenta potencial, mostrando-se vantajosa em vários aspectos para contribuir mais efetivamente na geração de eletricidade no SIN. As análises relativas ao consumo de eletricidade no setor residencial, e às projeções de demanda no horizonte de mais longo prazo, demonstram que intervenções nas

edificações buscando a eficiência energética tem significado devido à representatividade desse setor no consumo de energia elétrica brasileiro. Além disso, observa-se uma tendência de aumento no consumo de energia elétrica nos domicílios brasileiros, resultante do aumento e da melhor distribuição de renda da população e da busca por níveis satisfatórios de conforto, reduzindo a demanda reprimida no Brasil. Este cenário demonstra a importância de ações voltadas ao projeto arquitetônico e às características construtivas, visando a obtenção de eficiência energética, bem como a incorporação de sistemas solares para a geração de energia em unidades habitacionais unifamiliares no Brasil. 


\section{Premissas e estratégias para uma Casa Solar}

Este capítulo tem por objetivo descrever diferentes soluções de projeto e sistemas que, tipicamente, são incorporados a uma Casa Solar, promovendo de distintas maneiras a interação entre o sol e a arquitetura. O uso da fonte solar é abordado tanto no âmbito do condicionamento ambiental quanto da geração de energia, visando sempre à eficiência no consumo de energia e à redução de emissões de GEE. Sendo assim, este capítulo traz uma revisão bibliográfica acerca das formas de se aproveitar o sol na arquitetura. O protótipo Ekó House, tomado como modelo de Casa Solar para este estudo, é apresentado como exemplo prático de aplicação das premissas e estratégias descritas.

\subsection{O aproveitamento do sol na arquitetura}

A arquitetura tem a função essencial de proteção à chuva, ao sol, ao vento, ao frio e ao calor. Serra (1999) define os edifícios como 'refúgios de condições artificiais' ou 'ilhas de tranquilidade' em um mundo incômodo. Desta forma, entende-se como finalidade da arquitetura proporcionar espaços edificados com níveis apropriados de conforto ambiental aos ocupantes. O conforto ambiental está associado aos requisitos de habitabilidade, conforme norma brasileira de desempenho de edificações habitacionais (ABNT NBR15575: 2013) cujos critérios determinam, entre outros aspectos, condições para o bem estar térmico, lumínico ${ }^{47}$, acústico, antropométrico e a qualidade do ar. 0 estudo do conforto ambiental em edificações apresenta um escopo bastante amplo. Neste estudo, o enfoque é dado aos parâmetros de conforto térmico e lumínico associados ao aproveitamento do sol na arquitetura.

Durante muito tempo, o sol foi responsável por regular as atividades e a vida humana de um modo geral. Muitos grupos primitivos orientavam seus edifícios mais importantes ao sol, e os templos e tumbas egípcios eram posicionados de forma precisa em relação aos pontos cardiais e suas subdivisões. Posteriormente, a relação do homem com o sol

\footnotetext{
47 Também denominado por alguns autores como 'conforto visual'.
} 
passou a explorar seus efeitos terapêuticos e psicológicos. O sol passou a assumir um papel associado à salubridade, havendo uma preocupação com a qualidade e regularidade de insolação, e também em permitir a radiação solar nos períodos frios e evitá-la nos períodos de calor (OLGYAY, 1998).

Na Grécia, no século V a.C., a escassez da madeira, utilizada como lenha para aquecer o interior de edificações, promoveu um maior empenho em se aproveitar a energia do sol. Por meio do estudo da geometria solar, os gregos passaram a adotar em sua arquitetura estratégias para aproveitar a radiação solar nos períodos frios e evitar sua incidência direta durante os períodos de calor, tanto na escala da edificação quanto na escala urbana (ESPÍ, 1999).

Em Roma, no século I a.C., o difícil acesso à madeira, também utilizada em sistemas de aquecimento para edificações, contribuiu para que os romanos adotassem a técnica solar grega, que foi aprimorada e adaptada às diferentes regiões do império romano. Neste período o vidro passou a ser incorporado no fechamento das aberturas, contribuindo para ganhos solares passivos e para evitar perda de calor (ESPÍ, 1999; LAMBERTS et al., 2014). O aproveitamento do sol na arquitetura era essencial, a ponto de ser incluída em um código do imperador Justiniano no século VI, a primeira legislação ambiental de que se tem registro:

\begin{abstract}
"Se um objeto está colocado de modo a obstruir o sol de um heliocaminus ${ }^{48}$, deve-se afirmar que tal objeto gera sombra a lugar onde a luz do sol constitui uma absoluta necessidade. Sendo, assim, uma violação do direito ao sol do heliocaminus." (ESPÍ, 1999, tradução nossa).
\end{abstract}

Roaf (2007) aponta que, independentemente da escala do clima (global, regional, ou local) ele sempre irá influenciar a maneira com que os edifícios devem ser projetados em relação ao sol. Projetos climáticos de má qualidade fazem com que muitos edifícios superaqueçam mesmo em climas temperados ou frios, onde tradicionalmente estes problemas não existiam. Para um edifico solar passivo ser bem projetado, o arquiteto deve entender e respeitar a radiação solar, atentando para aspectos tais como a intensidade do sol no local de implantação do projeto, a sua incidência nos diferentes períodos do ano, o quanto do calor do sol será necessário para a edificação ao longo

\footnotetext{
${ }^{48}$ Avanços na ciência dos materiais permitiram aos romanos mais abastados utilizar vidro nas aberturas de fachadas orientadas a Sul (Hemisfério Norte) com a finalidade de obter aquecimento no inverno. Estas áreas envidraçadas e com a finalidade de aproveitar a radiação solar para o aquecimento foram denominadas Heliocaminus, que significa "fornalha solar". Estes ambientes eram construídos com materiais de alta capacidade térmica (massa térmica) e apresentavam esculturas decorativas tanto para aumentar a superfície quanto o coeficiente de transmissão de calor da superfície, para melhorar o fluxo de calor absorvido e liberado pela massa térmica (JUDKOFF, 2012, p. 492).
} 
do ano, a capacidade de armazenamento deste calor que o edifício deverá ter e os requisitos adicionais para controlar os ganhos de calor (ROAF, 2007).

Com o surgimento de sistemas de iluminação e, posteriormente, de climatização artificial, os projetistas tiveram a possibilidade de projetar edifícios independentemente das condições climáticas, já que estes sistemas viabilizaram a provisão artificial de condições ambientais confortáveis aos ocupantes (LAMBERTS et al., 2014). Esta facilidade resultou na disseminação de edificações ineficientes e somente habitáveis quando utilizados estes sistemas artificiais, e no consequente aumento do consumo de eletricidade para manter condições de habitabilidade nas edificações.

A ineficiência e o aumento da demanda por energia nas edificações implicam a necessidade de aumento na produção de energia, que resulta no consumo de recursos naturais e na emissão de GEE. É possível, então, perceber a importância de a arquitetura, novamente, resgatar o adequado aproveitamento do sol visando à obtenção do conforto ambiental em edificações e a eficiência no consumo de eletricidade.

\subsection{Premissas, estratégias e sistemas para uma casa Solar}

A adoção de premissas para o aproveitamento do sol na arquitetura requer a compreensão de quais demandas de uma edificação podem ser atendidas por este recurso, e quais estratégias e sistemas podem ser aplicados para suprir essas demandas.

A energia solar, de modo ativo ou passivo ${ }^{49}$, tem grande potencial para ser aproveitada em edificações, e pode suprir as diferentes demandas por energia em uma Casa Solar. $\mathrm{O}$ aquecimento de água pode ser provido por um sistema de coletores solares; a eletricidade pode ser gerada por meio de módulos fotovoltaicos; o aquecimento interno pode se dar por ganhos solares diretos ou também por sistema solar de aquecimento de água; a iluminação natural pode ser usada da forma mais proveitosa, enquanto módulos fotovoltaicos podem contribuir para alimentar o sistema de iluminação artificial e tomadas de força; o resfriamento de ambientes internos pode ser facilitado pela ventilação natural, e elementos de sombreamento podem evitar um aquecimento excessivo no interior de forma passiva (IEA, 2012). A Figura 3.1 ilustra as diferentes

\footnotetext{
49 Nesta dissertação, adota-se a classificação de sistemas e estratégias passivos e ativos conforme apresentado em IEA (2012), onde estratégias ou sistemas solares passivos são aqueles que se beneficiam da energia solar por meio da geometria, elementos ou materiais construtivos da edificação; e sistemas solares ativos são considerados aqueles que se utilizam da energia solar para gerar energia elétrica (como os fotovoltaicos) ou térmica (como os coletores solares para o aquecimento de água).
} 
demandas em uma edificação e as correspondentes estratégias e sistemas solares que atendem a essas demandas.

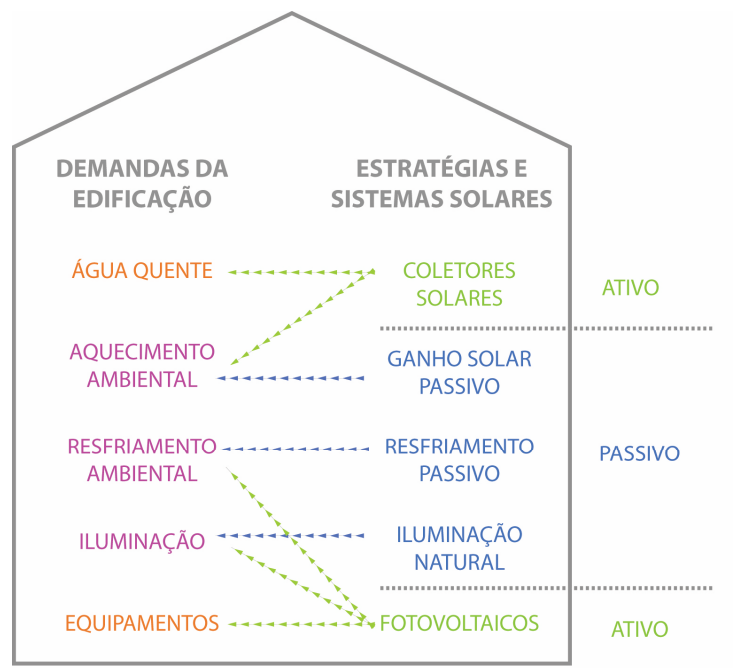

Figura 3.1: Demandas por energia em edificações e estratégias e sistemas solares que atendem a essas demandas.

Fonte: Adaptado de IEA, 2012.

Com base nesta interpretação de como usar a energia solar para suprir as necessidades de uma residência, é importante que a decisão de aproveitamento do sol seja tomada desde as primeiras etapas do projeto. Sendo assim, é fundamental estudar e conhecer as formas de se aproveitar este recurso na arquitetura. Nos itens seguintes são descritas sucintamente as premissas e estratégias que podem ser adotadas para um adequado aproveitamento do sol na arquitetura de uma Casa Solar.

\subsection{Protótipo Ekó House: exemplar de uma Casa Solar}

O protótipo Ekó House é uma REZ que adota como premissa no projeto de arquitetura o aproveitamento do sol para provisão de conforto ambiental e redução do consumo de energia. Diversas estratégias, que englobam a geometria do protótipo, o posicionamento, dimensionamento e sombreamento de aberturas, o uso de sistemas solares para obtenção de energia (térmica e elétrica), são incorporadas nas soluções de projeto. O protótipo é um exemplar de uma Casa Solar, e é adotado neste estudo para demonstrar a adoção dessas premissas e estratégias de forma prática e aplicada. Para tanto, é realizada uma análise crítica do protótipo no decorrer deste capítulo. A Figura 3.2 ilustra o protótipo Ekó House. 


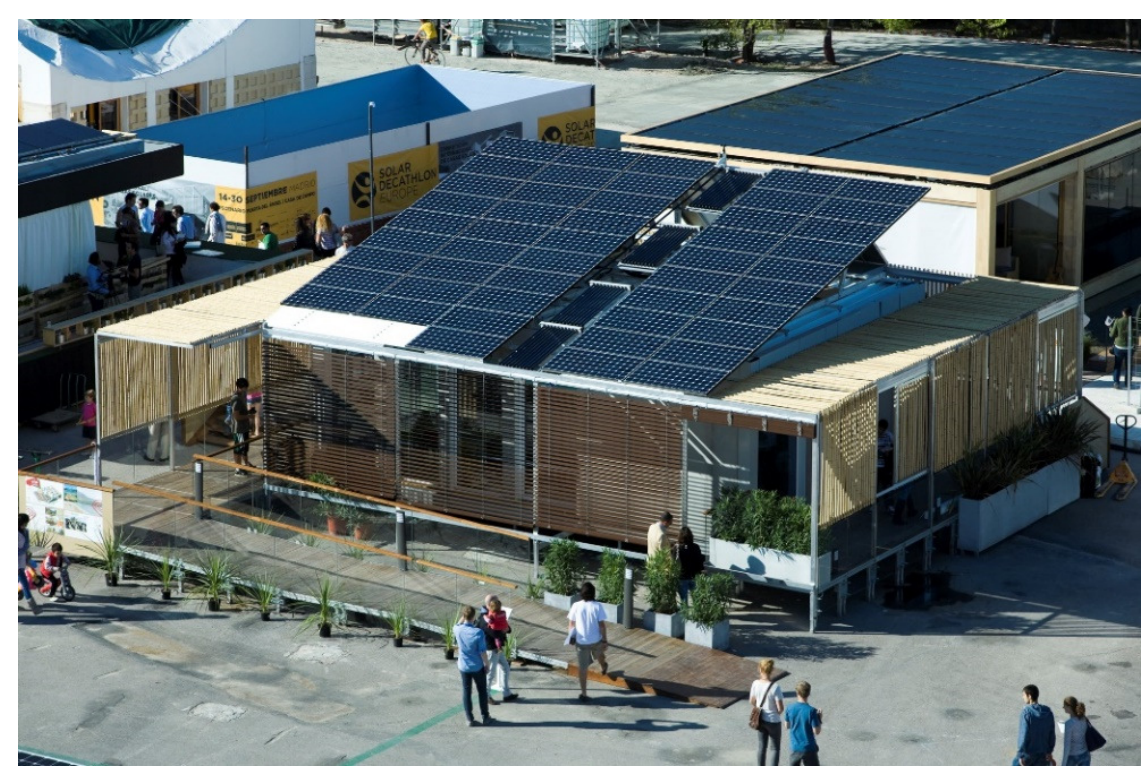

Figura 3.2: Protótipo Ekó House durante o SDE 2012, realizado na cidade de Madri, Espanha. Fonte: CI+D+Art/SDE 2012.

Tendo como meta a participação no SDE 2012, o projeto da Ekó House ficou sujeito a diferentes condicionantes, tanto devido à necessidade de atender ao regulamento específico da competição, como de se adequar a uma logística que compreendeu etapas de montagem no Brasil, transporte à Espanha para participação no evento, montagem na Villa Solar (nome dado ao local onde aconteceu a competição e exposição das casas), desmontagem, e transporte de retorno ao Brasil.

O projeto teve que se adequar às regras que definiam áreas (área condicionada entre 45 e $70 \mathrm{~m}^{2}$, e área de projeção máxima de $150 \mathrm{~m}^{2}$ ), estar construído dentro dos limites de um envelope solar ${ }^{50}$, atender a parâmetros de ergonomia e segurança, e a legislações específicas (SDE, 2012). O protótipo foi projetado para ser ocupado por duas pessoas.

Como resultado destas delimitações, o protótipo foi organizado em três módulos, denominados M1, M2 e M3. O módulo M1 abriga as funções básicas de uma casa: cozinha, banheiro e dormitório. Já os módulos M2 e M3 configuram a área social do protótipo. Externamente há uma área de deck e varandas, que servem como expansão da área social, e configuram um espaço de transição entre o núcleo condicionado da casa e a área exterior. A Figura 3.3 ilustra esta organização do protótipo em planta baixa.

50 Delimitação tridimensional para os protótipos participantes do SDE 2012, utilizada para evitar sombreamento e assegurar o acesso ao sol de forma equivalente para todos os protótipos. 


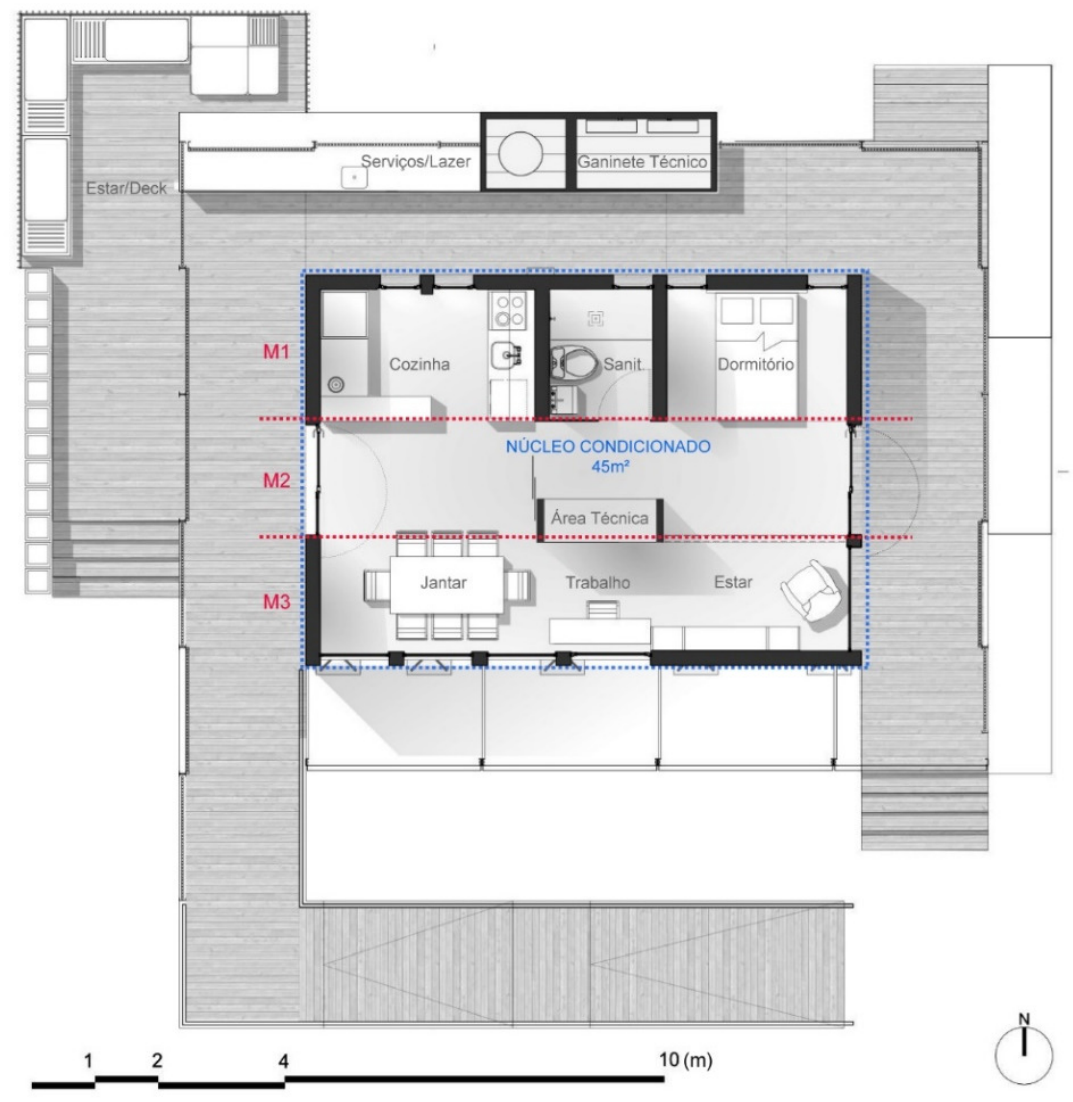

Figura 3.3: Planta baixa do protótipo Ekó House considerando sua implantação em Madri (Hemisfério Norte).

Fonte: Projeto Ekó House, 2012.

O núcleo condicionado do protótipo é de $45 \mathrm{~m}^{2}$; a área de projeção soma $120 \mathrm{~m}^{2}$ incluindo varandas, deck, rampas e escadas de acesso. O módulo M2 abriga um compartimento central destinado aos quadros elétrico e de automação. Há um gabinete técnico na área externa, que abriga equipamentos mecânicos, reservatórios e controles dos sistemas de instalações elétricas, de automação, hidráulica (água fria e quente) e de geração de energia fotovoltaica. As premissas e estratégias do protótipo são apresentadas ao longo do capítulo.

\subsection{Geometria solar}

Para aproveitar a radiação solar em uma edificação, ou proteger suas superfícies da incidência direta do sol, é necessário estudar a geometria solar para determinar a posição e os ângulos de incidência do sol sobre as diferentes faces da edificação, ao longo do dia e do ano, para um determinado local de implantação, considerando o movimento aparente do sol. 
Um observador em qualquer ponto do globo terrestre tem a impressão de que o sol se movimenta ao redor da Terra ao longo do dia e do ano, devido aos movimentos de translação e rotação da Terra e à inclinação do seu eixo (cerca de $23,5^{\circ}$ ). Este efeito resulta no movimento aparente do sol (FROTA, SCHIFFER, 2003).

\begin{abstract}
"Na prática, para um determinado observador na Terra, o movimento aparente do Sol é descrito como uma série sucessiva de circunferências na esfera celeste, com inclinações sobre o plano do horizonte variando em função da latitude do observador. Esse movimento diário do Sol percebido na esfera celeste como circunferência é denominado trajetória aparente do Sol. Assim, podese determinar uma trajetória aparente do sol para cada dia do ano, em função de cada latitude diversa na Terra" (FROTA, SCHIFFER, 2003, p. 81).
\end{abstract}

Nas regiões situadas nos trópicos, geometrias que resultam em fachadas mais alongadas com orientação a Norte e a Sul conseguem um melhor aproveitamento do sol ao longo do ano. Isso ocorre porque no verão, quando o Sol está mais a pino, incide com menor intensidade nas superfícies da envoltória orientadas a Norte (para o Hemisfério Sul) do que naquelas orientadas a Leste e Oeste. Já no inverno, quando o Sol está mais baixo, a incidência nas superfícies orientadas a Norte é maior do que nas orientadas a Leste e Oeste, conforme ilustra a Figura 3.4. Sendo assim, essa forma geométrica se mostra mais favorável para aumentar os ganhos de calor passivo nos períodos frios e reduzir esses ganhos nos períodos de calor ${ }^{51}$.

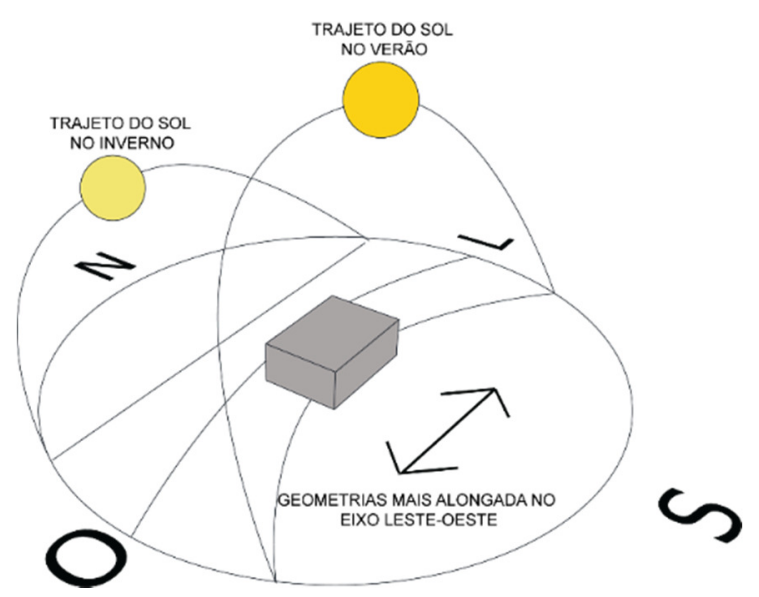

Figura 3.4: Movimento aparente do sol e geometria mais favorável para seu aproveitamento na arquitetura Fonte: Elaboração própria.

\footnotetext{
51 Fachadas expostas a Sul (Hemisfério Norte e 40ำ de latitude) recebem no inverno aproximadamente três vezes mais energia solar do que as expostas a Leste e Oeste; enquanto que no verão, a radiação que incide nas faces Norte e Sul equivale à metade da radiação incidente em fachadas orientadas a Leste e Oeste (OLGYAY, 1998). Superfícies mais alongadas e aberturas nas fachadas orientadas a Norte e a Sul são também apontadas como mais adequadas à arquitetura em zonas tropicais (CORBELLA, 2003).
} 
A arquitetura vernácula ${ }^{52}$ traz muitos exemplos de soluções de adaptação às condições climáticas, compondo um vasto repertório de estratégias. Com relação à incidência de radiação solar nas diferentes orientações de fachada, Olgyay (2010) exemplifica uma estratégia adequada à orientação solar presente no povoado indígena de Acoma, Estados Unidos, onde as casas estão agrupadas lado a lado na direção Leste-Oeste, protegendo estes planos da incidência da radiação solar e dispondo as áreas de paredes e aberturas expostas à radiação solar nos planos orientados a Norte e Sul. A Figura 3.5 ilustra este exemplo.

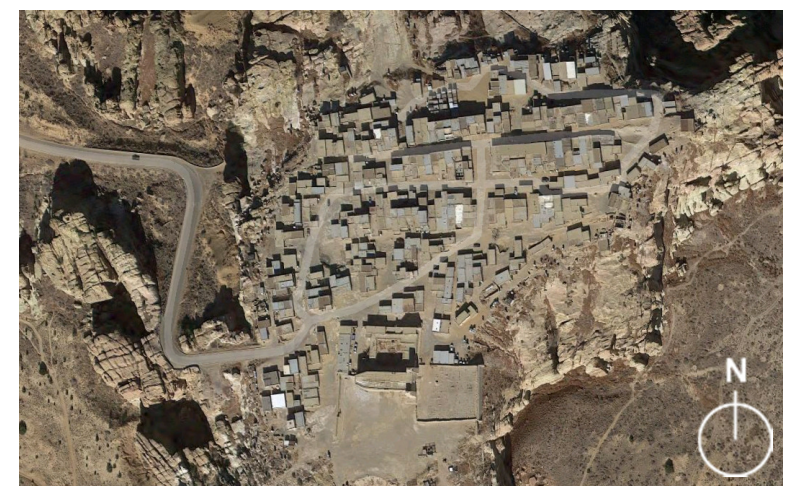

Figura 3.5: Povoado indígena de Acoma.

Fonte: Google Earth, (02014 Google.

Para estudar a geometria solar, pode-se recorrer ao uso de cartas solares. Estas cartas representam graficamente a trajetória aparente do sol projetada sobre uma superfície horizontal, para latitudes específicas (BROWN; DEKAY, 2004; FROTA; SCHIFFER, 2003; OLGYAY, 1998). As cartas solares permitem determinar os horários de insolação sobre superfícies horizontais e verticais para uma dada orientação (FROTA; SCHIFFER, 2003). Na carta solar, para um determinado dia e horário, é possível ler também o azimute e a altura solar. O ângulo do azimute é indicado no círculo periférico da carta solar. A altura solar está indicada nos círculos concêntricos, que vão de $0^{\circ}$ a $90^{\circ}$. Estas informações permitem, por exemplo, fazer um estudo geométrico do sombreamento resultante de elementos de proteção aplicados às fachadas (BROWN; DEKAY, 2004).

Na Figura 3.6 são demonstradas as cartas solares das cidades de São Paulo e Madri. $\mathrm{Na}$ carta de São Paulo está exemplificada a leitura das horas de insolação para uma fachada orientada a NE. Os horários coincidentes com a área da carta demarcada em cinza (que representa a região da abóboda celeste que se situa atrás da fachada orientada a NE) são os horários em que o sol não irá incidir sobre esta superfície. $\mathrm{Na}$ Carta de Madri está representada a leitura que permite determinar o azimute e altura solar. Às $10 \mathrm{~h}$ da manhã do dia $1^{\circ}$ de outubro, o azimute solar é de $124^{\circ} \mathrm{e}$ a altura solar

52 Própria de um país, nação, região (HOUAISS et al., 2009). 
de $30^{\circ}$. É possível observar ainda o quão mais longo é o movimento do sol no verão em relação ao inverno, e como a altura do sol é menor no inverno e maior no verão. Isso ilustra os benefícios das fachadas mais alongadas com orientação a Norte no caso de São Paulo, e a Sul no caso de Madri.
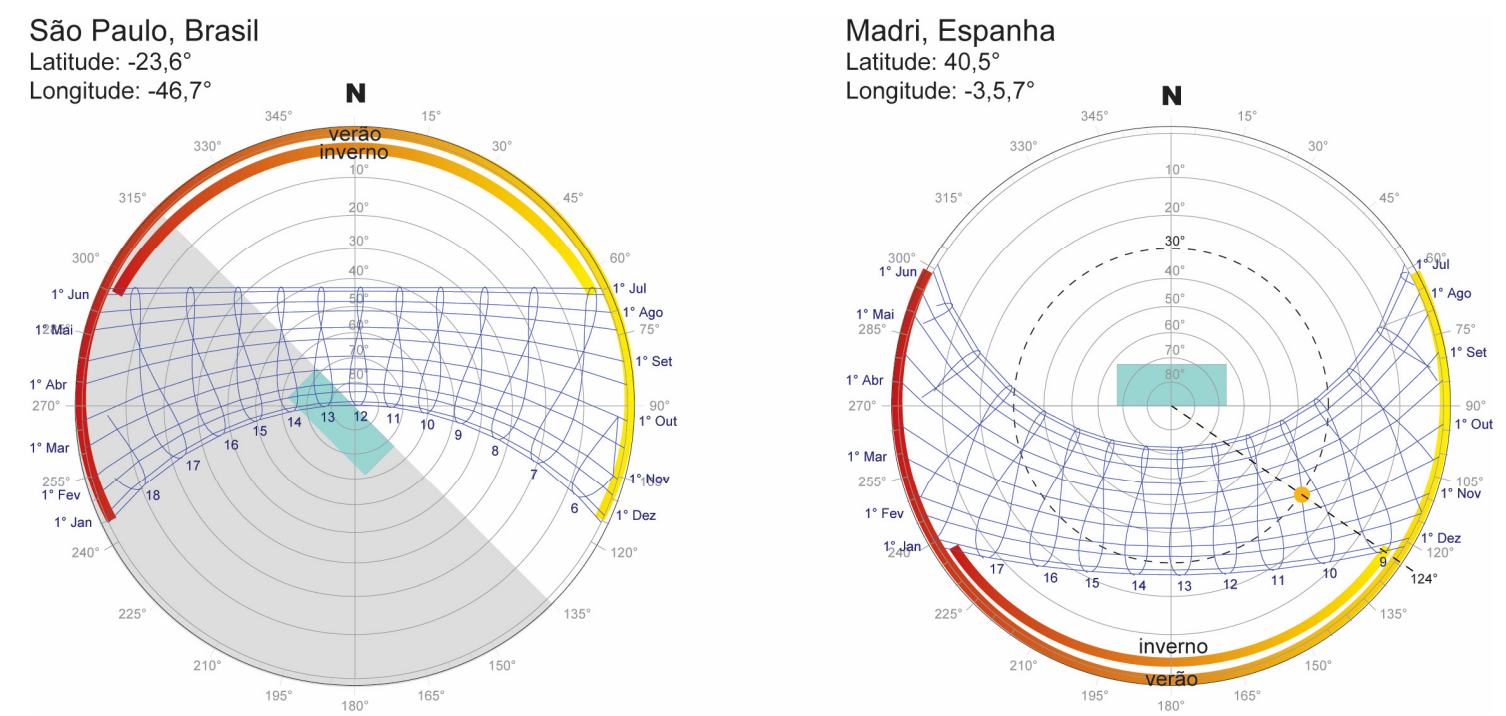

Figura 3.6: Carta solar e leitura das horas de insolação, azimute e altura solar. Fonte: Elaborado a partir de WeatherTool, @Autodesk Ecotect Analysis 2011.

Leituras simples como as possibilitadas por cartas solares podem orientar as premissas iniciais de projetos em relação à orientação solar. O estudo de geometria solar e sua aplicação sobre projetos arquitetônicos pode ser realizado também por meio de maquetes físicas e eletrônicas, que facilitam o estudo do efeito da radiação solar e das sombras sobre o edifício como um todo (HAGGARD, et al., 2009). Desta forma, é possível antever e projetar adequadamente as edificações quanto à orientação solar, volumetria do envelope, dimensionamento e orientação de aberturas e elementos de proteção solar. Um estudo acurado considerando estes aspectos no partido arquitetônico pode influenciar substancialmente as condições de conforto e o consumo de energia para o condicionamento ambiental de uma edificação.

\subsubsection{A geometria solar aplicada ao protótipo Ekó House}

O protótipo Ekó House ${ }^{53}$ possui uma volumetria mais alongada no eixo Leste-Oeste, de modo que as maiores fachadas estão orientadas a Norte e Sul para otimização do aproveitamento da radiação solar. Já as fachadas Leste e Oeste, menos favoráveis para

\footnotetext{
${ }^{53}$ Considerando sua implantação na Espanha (Hemisfério Norte), durante a participação no Solar Decathlon Europe 2012.
} 
o aproveitamento do sol ao longo do ano, são as de menor superfície. O gráfico da Figura 3.7 mostra a radiação solar incidente nas diferentes fachadas do protótipo ao longo do ano. É possível observar que entre os meses de Abril e Agosto, período mais quente, as fachadas orientadas a Leste e Oeste recebem mais radiação do que a Sul, enquanto que nos meses de inverno a fachada orientada a Sul recebe entre duas e três vezes mais radiação do que as orientadas a Leste e Oeste.

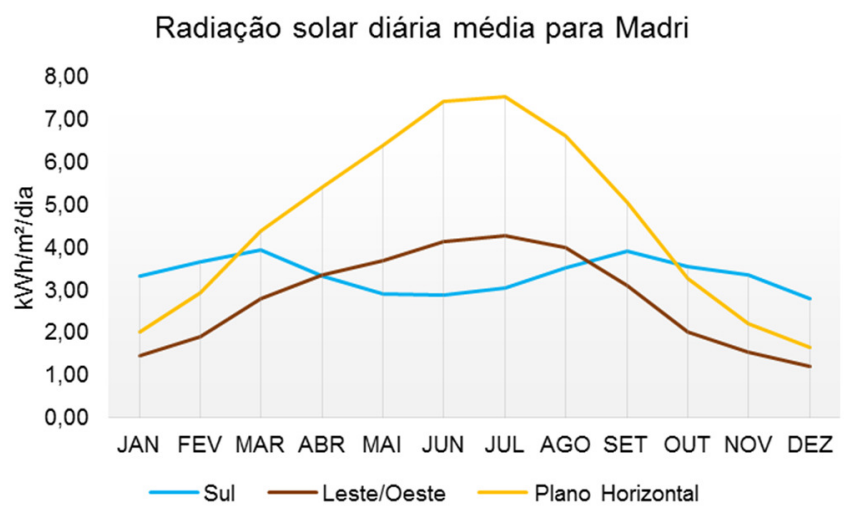

Figura 3.7: Radiação solar diária média para a cidade de Madri.

Fonte: RETScreen®.

A organização do espaço interno foi definida com base na orientação das fachadas. $O$ espaço social - sala de estar e jantar - que é um espaço de permanência prolongada, foi alocado ao longo da fachada Sul. O dormitório se beneficia da insolação Leste, enquanto a cozinha foi orientada a Oeste. O banheiro, espaço de menor permanência foi posicionado na parte central do módulo M1. O estudo da geometria solar foi aplicado, em um primeiro momento, na definição da geometria do protótipo e na organização e ocupação do espaço interno, e na disposição das aberturas.

\subsection{Estratégias para o conforto térmico}

O ar combina três parâmetros que influenciam o conforto térmico de um ambiente: temperatura, umidade e velocidade (ou movimento) (SERRA, 1999). A temperatura influi na sensação de calor devido ao contato com a pele e também pela respiração. A umidade interfere na capacidade do corpo de transpirar. Se a umidade é baixa, quando a temperatura é alta, a evaporação do suor é facilitada e, com isso, o corpo cede calor e umidade ao ar, o que possibilita um resfriamento do corpo.

Quando as condições climáticas são analisadas com base na temperatura e umidade, é possível definir quatro tipos de clima: quente e seco, quente e úmido, frio e temperado 
(BEHLING et al., 2002; OLGYAY, 1998; SERRA, 1999). A arquitetura que busca se adaptar às condições climáticas por meio de suas próprias soluções de projeto, de seus próprios elementos, utilizando de modo favorável essas condições, e buscando satisfazer as necessidades de conforto térmico dos ocupantes é uma arquitetura dita bioclimática $^{54}$ (CORBELLA, 2003; LAMBERTS et al., 2014; OLGYAY, 1998).

A arquitetura vernácula brasileira apresenta muitos exemplos de aplicação dos princípios bioclimáticos, tanto nas técnicas trazida pelos colonizadores e imigrantes, e que foram adaptadas aos diferentes climas ao longo do território brasileiro, quanto nas construções de povos nativos. A arquitetura dos imigrantes portugueses, alemães e italianos traz exemplos como o uso de elementos de sombreamento, estratégias para ganhos solares passivos, uso de inércia térmica e ventilação natural (WEIMER, 2005). Um exemplo extremo é o de tribos indígenas brasileiras.

"O que aprendemos com as migrações destes construtores indígenas
é que eles sempre adaptaram as formas e materiais de suas casas às
circunstancias ambientais, sejam elas água, sol ou terra. Compare isso
com a nossa atitude (não só agora, mas ao longo dos séculos) de tentar
mudar a natureza para abrigar as casas e cidades de 'nossos sonhos'.
O resultado é a destruição da natureza em larga escala ao se construir
casas e cidades idênticas em todos os lugares do mundo, seja no ártico
ou na floresta tropical" (VAN LENGEN, 2013, p. 106).

A migração das tribos e a consequente necessidade de reedificar seus abrigos não são hábitos comparáveis ao atual modelo ocidental de vida urbana. No entanto, estes exemplos, entre outros já citados, demonstram a viabilidade e reforçam a importância de se buscar uma adaptação da arquitetura ao clima local, objetivando o consumo racional de recursos, inclusive os recursos energéticos.

Uma ferramenta de estudo das estratégias a serem adotadas para cada clima é a carta bioclimática (ou psicrométrica). Olgyay ${ }^{55}$ foi o primeiro a desenvolver um diagrama bioclimático, tendo como abscissa a temperatura do ar e como ordenada a umidade relativa do ar (LAMBERTS et al., 1997). Em 1992 Givoni publica um trabalho ${ }^{56}$ no qual apresenta uma versão de carta bioclimática adequada a países em desenvolvimento. A Figura 3.8 ilustra a carta bioclimática adaptada pela NBR 15220-357 (ABNT, 2003) a

\footnotetext{
54 O termo bioclimático (ou a bioclimatologia) se refere ao estudo que associa o clima e os elementos físicos do entorno às reações humanas, tanto físicas como psicológicas (OLGYAY, 1998).

55 Victor Olgyay desenvolveu, no início da década de 1690, um diagrama bioclimático, que serviu de base para a carta bioclimática desenvolvida por Baruch Givoni em 1969.

56 GIVONI, B. Comfort, climate analysis and building design guidelines. Energy and Buildings, vol. 18, p. 11-23, 1992.

57 Cartas bioclimáticas podem também considerar dados de Umidade Absoluta do Ar (grama de vapor de água no ar/quilograma de ar seco) e Temperatura do Ponto de Orvalho $\left({ }^{\circ} \mathrm{C}\right)$, conforme demonstrado nas cartas utilizadas nas análises do Capítulo 4 e Apêndice C.
} 
partir da carta elaborada por Givoni, com as zonas correspondentes a cada estratégia que deve ser adotada.

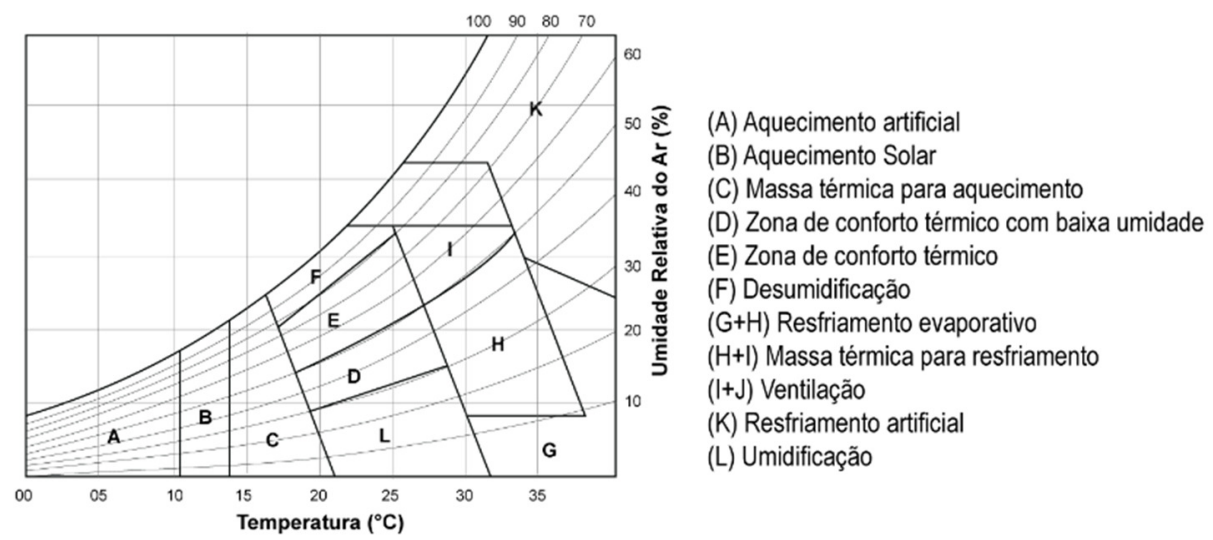

Figura 3.8: Carta bioclimática adaptada e estratégias de condicionamento térmico.

Fonte: Adaptado de ABNT, 2003.

Um ponto situado mais à direita e acima na carta bioclimática da Figura 3.8, por exemplo, representa uma combinação de temperatura e umidade relativa do ar que resulta em maior sensação de calor. Nestas condições, estratégias que promovam o resfriamento devem ser adotadas. Sendo assim, dados de temperatura e umidade relativa do ar podem ser plotados diretamente sobre o gráfico a fim de identificar as estratégias mais apropriadas para um determinado local ao longo do ano.

Nos itens subsequentes são apresentados os conceitos relacionados às estratégias passivas orientadas ao conforto térmico das edificações residenciais e relacionadas ao controle dos ganhos solares passivos, à ventilação natural e ao resfriamento evaporativo. No Apêndice B são apresentados conceitos e dados sobre propriedades térmicas dos materiais e elementos construtivos que fundamentam as discussões das estratégias supracitadas.

\subsubsection{Controle dos ganhos solares passivos}

A radiação solar pode penetrar diretamente na edificação através das aberturas ou ser absorvida pelas superfícies de paredes e coberturas. Ao incidir sobre as superfícies, a radiação solar resulta em um ganho de calor. Esse ganho, e o consequente armazenamento do calor no ambiente, dependem da intensidade da radiação solar $\mathrm{e}$ das propriedades térmicas dos materiais de fechamento e internos à edificação (FROTA; SCHIFFER, 2003).

Os ganhos solares em edificações podem ser diretos ou indiretos. Os ganhos diretos acontecem quando a radiação solar incide diretamente no interior da edificação, através 
de aberturas laterais ou zenitais. O uso de elementos transparentes permite ganhos diretos e pode contribuir para gerar o efeito estufa quando há necessidade de aquecimento do ambiente interior (LAMBERTS et al., 2014; ROAF et al., 2007). Já os ganhos indiretos ocorrem quando elementos de elevada inércia térmica ${ }^{58}$ são expostos à radiação solar direta. Estes elementos acumulam o calor, e emitem este calor para o ambiente, por meio da radiação e convecção, quando a temperatura do ambiente interno diminui (FROTA, SCHIFFER, 2003; ROAF et. al., 2007).

Os diagramas na Figura 3.9 demonstram formas passivas de aproveitamento do sol, por meio de ganhos diretos e indiretos. São exemplos que se constituem em soluções possivelmente aplicáveis à arquitetura de uma Casa Solar no Brasil. O diagrama (A) demonstra formas de ganho direto ou semidireto através de uma estufa de vidro. Os diagramas (B), (C) e (D) demonstram formas de ganhos passivos indiretos, onde paredes de alta massa térmica acumulam o calor que posteriormente será liberado ao ambiente a ser aquecido. No caso da Parede Trombe são integradas aberturas para a circulação de ar, de modo que o calor é transmitido ao interior não apenas por dissipação da radiação incidente, mas também por convecção natural do ar.

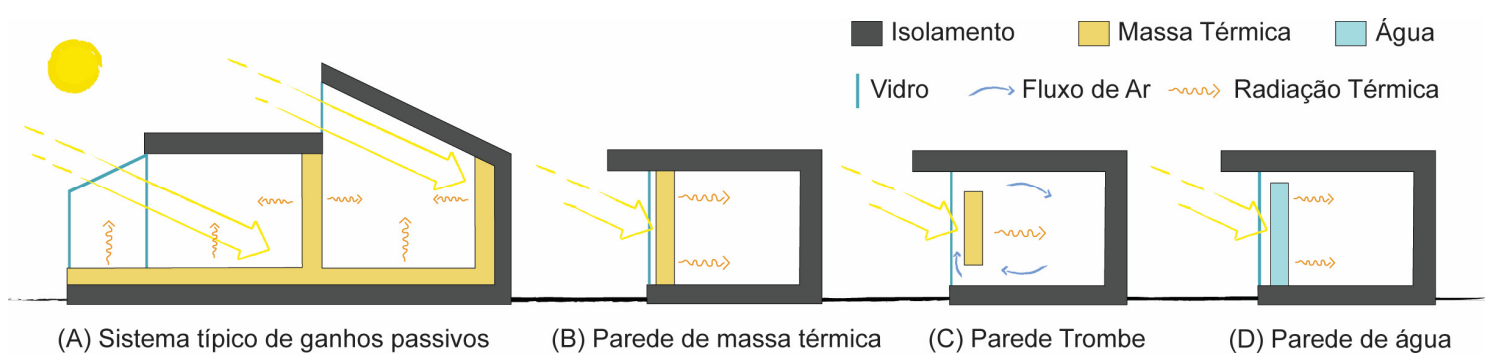

Figura 3.9: Sistemas solares passivos.

Fonte: Adaptado de ROAF, 2007.

Em alguns climas ou estações do ano é necessário evitar os ganhos solares passivos. Neste caso, podem ser aplicados elementos de proteção junto às áreas de aberturas. São exemplos os beirais, grelhas, brise soleil, marquises, persianas externas e internas, vegetação, entre outros. O efeito da proteção solar destes elementos sobre superfícies transparentes depende de fatores como a capacidade de refletir a radiação solar do material, a localização desta proteção e o efeito relativo à radiação solar e às convecções do calor, e da sua distribuição em relação às superfícies transparentes (OLGYAY, 1998). A Figura 3.10 ilustra alguns dos possíveis elementos de proteção solar e seus respectivos coeficientes de sombreamento ${ }^{59}$.

\footnotetext{
58 Ver item 3.5.1.1.

$59 \mathrm{O}$ conceito de Coeficiente de Sombreamento (CS) foi introduzido pela a ASHRAE (American Society of Heating, Refrigeration and Air Conditioning) para permitir a análise comparativa entre os vários tipos de
} 


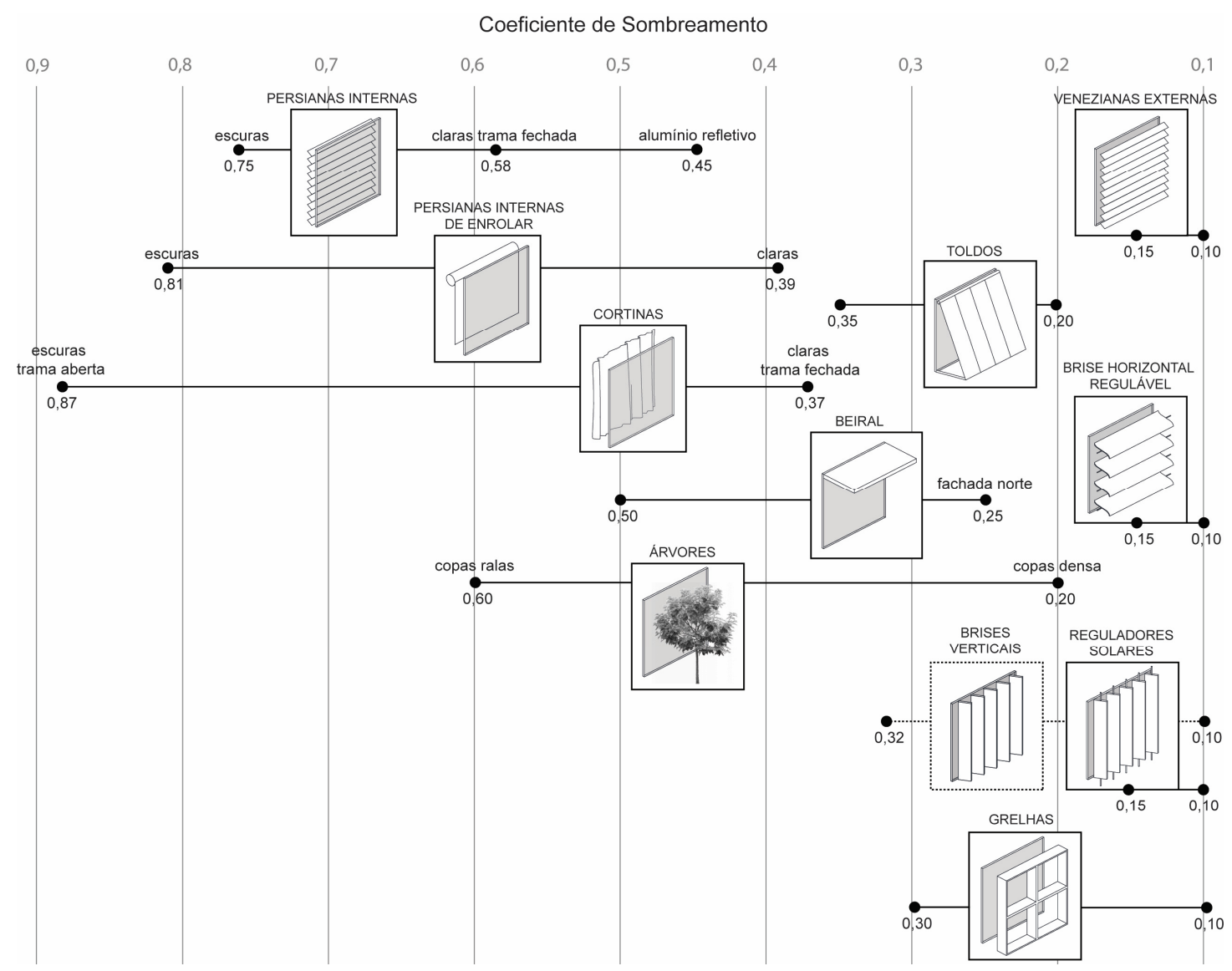

Figura 3.10: Coeficientes de sombreamento para diferentes elementos de proteção solar. Fonte: A partir de BROWN; DEKAY, 2004; OLGYAY, 1998.

Por meio da seleção dos materiais de construção, do arranjo dos elementos e da orientação da edificação, esses ganhos podem ser potencializados no inverno e inibidos no verão. Essas soluções devem ser levadas em consideração, visto que estes ganhos impactam o conforto dos ocupantes e a eficiência no consumo de energia para manutenção do conforto ambiental.

Nos itens subsequentes são apresentadas características tais como inércia térmica, isolamento térmico e fator solar, que interferem na transferência de calor dependendo das condições de incidência da radiação, da opacidade ou transparência à radiação, das condições da superfície, da massa, espessura e demais propriedades dos materiais e elementos de construção.

envidraçamento e sua combinação com diversos tipos de proteção (como por exemplo: brises, cortinas, beirais). O CS é definido como a razão entre o Fator Solar (transmissão direta + parcela da energia absorvida que flui para o interior do ambiente por re-irradiação e convecção) e a mesma grandeza correspondente ao vidro padrão (vidro com 3mm de espessura, incolor), não sombreado. Informação disponível em: <http://www.usp.br/fau/deptecnologia/docs/bancovidros/termica.htm>. Acesso em: 15/02/2015. 


\subsubsection{Inércia Térmica}

A inércia térmica associa dois importantes fenômenos do comportamento térmico do edifício, o amortecimento e 0 atraso ${ }^{60}$ da onda de calor pelo aquecimento ou resfriamento dos materiais. Sendo assim, quanto maior a inercia térmica da edificação, maiores serão o amortecimento e o atraso (FROTA; SCHIFFER, 2003). Materiais que apresentam alta inércia térmica podem ser usados para controle dos ganhos e perdas de calor em uma edificação no calor ou frio (BROWN; DEKAY, 2004; GALLOWAY, 2004). Neste contexto, a inércia térmica pode ser definida como "a resistência oferecida pelos sistemas térmicos à tentativa de alterar o seu estado termodinâmico" (LIMA, 1995, p. 7).

A inércia térmica contribui na redução da amplitude da temperatura interior em relação à temperatura exterior, e para absorver picos de temperatura. Um clima favorável para a aplicação da inércia térmica é o clima quente e seco, onde há uma grande amplitude térmica entre o dia e a noite. A massa térmica exposta à radiação solar absorve calor durante o dia e o devolve ao ambiente interior durante a noite, quando a temperatura diminui. No período noturno, a massa térmica resfria e, portanto, contribui para reduzir a temperatura do ambiente interno durante $\mathrm{o}$ dia, pois volta a absorver calor (LAMBERTS et al., 1997).

Em locais de clima frio, é possível usar massa térmica em elementos internos da edificação, e isolamento térmico nas paredes externas e aberturas, de modo que o calor retido no material exposto à radiação solar ao longo do dia seja irradiado ao ambiente interno (ROAF, 2007), conforme demonstrado nos diagramas da Figura 3.9. Neste caso o isolamento ajuda a conservar este calor no ambiente interior, e também o calor proveniente de equipamentos internos e da atividade dos ocupantes. Exemplos de materiais de elevada massa térmica são as pedras, tijolos maciços, paredes de adobe, concreto, água e coberturas verdes. A Tabela 3.1 relaciona alguns materiais $\mathrm{e}$ propriedades que influenciam no seu desempenho.

$60 \mathrm{O}$ atraso térmico é definido como o "tempo transcorrido entre uma variação térmica em um meio e sua manifestação na superfície oposta de um componente construtivo submetido a um regime periódico de transmissão de calor" (ABNT NBR 15220-1:2005. p. 2). O atraso depende da capacidade térmica dos componentes construtivos e da ordem de disposição das camadas destes componentes. 


\begin{tabular}{|c|c|c|c|}
\hline & Espessura (cm) & $\begin{array}{c}\text { Valor de (U) } \\
\left(\mathrm{cal} / \mathrm{cm}^{2} / \mathrm{min}\right)\end{array}$ & $\begin{array}{c}\text { Atraso térmico } \\
\text { (horas) }\end{array}$ \\
\hline \multirow{2}{*}{ Pedra } & 20 & 0,0031 & 5,5 \\
\hline & 61 & 0,0017 & 15,5 \\
\hline \multirow{2}{*}{ Concreto } & 5 & 0,0045 & 1,1 \\
\hline & 40,6 & 0,0021 & 10,2 \\
\hline \multirow{2}{*}{ Tijolo Comum } & 10 & 0,0028 & 2,3 \\
\hline & 40,6 & 0,0012 & 12 \\
\hline \multirow{2}{*}{ Madeira } & 1,25 & 0,0031 & 0,17 \\
\hline & 5 & 0,0014 & 1,3 \\
\hline \multirow{2}{*}{ Painel Isolante } & 1,25 & 0,0019 & 0,08 \\
\hline & 15 & 0,00023 & 5 \\
\hline
\end{tabular}

Tabela 3.1: Propriedades de materiais quanto à transmitância térmica (U) e tempo de atraso térmico. Fonte: OLGYAY, 1998.

Em edifícios de elevada inercia térmica, essa característica pode atuar desfavoravelmente ao condicionamento ambiental interno, por exemplo, quando a ocupação é apenas diurna (o que, via de regra, não se aplica a edificações residenciais) ou quando os ganhos solares de inverno são pouco significativos. Nestas situações, a elevada inercia térmica pode contribuir para uma demora a reestabelecer as condições de conforto por sistemas mecânicos de climatização, aumentando o consumo de energia dos mesmos (LIMA, 1995).

Por outro lado, para edifícios de baixa inércia, os materiais denominados PCM (Phase Change Material), materiais que mudam de fase, têm sido utilizados para aumentar a massa térmica (SANTOS, 2013). São materiais que absorvem ou liberam energia durante sua mudança de fase, em temperatura na faixa de conforto ambiental. Os PCM compõem um grupo de materiais capazes de trocar energia com o ambiente, sob a forma de calor, caracterizando a troca térmica por via úmida. Para os materiais de construção de interesse no condicionamento passivo, essa energia por unidade de massa é denominada calor latente de fusão. Em função desta característica, este material é eficiente para absorver picos de temperatura. Exemplos de aplicação são a incorporação de microcápsulas de PCM em painéis de gesso, em argamassas ou armazenamento do material em tanques ou compartimentos que estejam em contato entre o ar interior (SÁNCHEZ, 2011).

\subsubsection{Isolamento térmico}

Para evitar ganhos ou perdas térmicas indesejadas é importante que todas as superfícies de fechamento, tanto opacos como translúcidos, apresentem bom isolamento térmico. Assegurar a estanqueidade dos componentes construtivos e evitar 
pontes térmicas também são cuidados essenciais quando se adota o isolamento térmico como estratégia em uma edificação.

O isolamento térmico é uma estratégia indicada a situações onde se deseja evitar perdas e ganhos térmicos. Em climas frios, por exemplo, quando se aplicam estratégias de ganho solar passivo, ou mesmo sistemas ativos de aquecimento, o isolamento é importante para manter este calor no interior do ambiente por um maior tempo. Em climas onde a temperatura e umidade são altas e a estratégia do uso de massa térmica para resfriamento torna-se ineficiente, passam a ser indicados sistemas de resfriamento artificial; nessas condições o isolamento térmico também contribui para que estes sistemas mecânicos possam ser utilizados com maior eficiência. $\mathrm{O}$ isolamento térmico de um material pode ser determinado pelo seu coeficiente de Condutividade Térmica $(\lambda)$. Quanto mais alto o valor de $\lambda$, menor o desempenho do material enquanto isolante térmico (LAMBERTS et al., 2014). A Tabela 3.2 mostra alguns materiais e seus respectivos níveis de condutividade térmica.

\begin{tabular}{|c|c|}
\hline Material & $\lambda(\mathrm{W} / \mathrm{m} \cdot \mathrm{K})$ \\
\hline Cortiça & 0,045 \\
\hline Fibra de Madeira & 0,05 \\
\hline Isolante a base de celulose solto & 0,042 \\
\hline Isolante a base de celulose injetado & 0,039 \\
\hline Madeira & $0,12-0,29$ \\
\hline Compensados, aglomerados e placas de fibras ou partículas de madeira & $0,12-0,58$ \\
\hline Fibrocimento & $0,65-0,95$ \\
\hline PVC (poli cloreto de vinila) & $0,20-0,40$ \\
\hline Poliestireno expandido & 0,035 \\
\hline Poliuretano & 0,016 \\
\hline Tijolos e telhas de barro & $0,70-1,05$ \\
\hline Concreto & $0,19-1,63$ \\
\hline Lã de vidro & 0,045 \\
\hline Lã de rocha & 0,045 \\
\hline Pedras & $1,6-3,0$ \\
\hline Vidro & 1,10 \\
\hline Painel de Isolamento à Vácuo & $0,00213^{61}$ \\
\hline Aerogel ${ }^{62}$ & $0,013^{63}$ \\
\hline
\end{tabular}

Tabela 3.2: Materiais e isolamento térmico.

Fonte: A partir de DURAN, 2011; LAMBERTS et al., 1997; ROAF et al., 2007; ABNT NBR15.220-2: 2005.

A escolha dos isolantes depende da necessidade de isolamento, do desempenho quanto à durabilidade, resistência e comportamento ao fogo, à chuva e também de questões técnicas referentes à sua instalação em edificações. Duran (2011) aponta que

\footnotetext{
61 Dow Corning® Vacuum Insulation Panel. Disponível em: <http://www.dowcorning.com/content/publishedlit/62-155601.pdf>. Acesso em: 12/09/2013.

62 Nome comercial para isolante de alto desempenho à base de sílica amorfa sintética, fibra de vidro de filamento contínuo e hidróxido de magnésio

${ }^{63}$ Aspen Aerogels. Disponível em: <http://www.aerogel.com/Aspen_Aerogels_Spaceloft.pdf>. Acesso em: 12/09/2013.
} 
isolantes que usam fibras naturais de cânhamo ou madeira, assim como isolantes em manta de lã de ovelha, possuem um bom desempenho e sua produção consome menos energia que alguns isolantes sintéticos.

\subsubsection{Fator solar (Fs)}

Com relação às áreas de aberturas, além da orientação, dimensão e desempenho das esquadrias, as propriedades do vidro são um importante fator nos fluxos de energia através das aberturas, podendo permitir ou barrar os ganhos térmicos por radiação solar e as perdas de calor do ambiente interior (BROWN; DEKAY, 2004; LAMBERTS et al., 2014).

As propriedades de absortividade, emissividade e transmissividade determinam o Fator Solar $(\mathrm{Fs})^{64}$, característica comumente associada às superfícies envidraçadas, que é, simplificadamente, a "razão entre a quantidade de energia que atravessa uma janela pelo que nela incide" (LAMBERTS et al., 2014, p. 221). Sendo assim, se o fator solar de um determinado vidro é igual a 0,80 , significa que $80 \%$ da radiação que incide sobre uma janela com esse vidro são transmitidos diretamente ou indiretamente ao interior. Este fator é também utilizado para expressar a proteção solar que pode ser obtida por meio do uso de elementos como quebra-sol, persianas e cortinas (FROTA, SCHIFFER, 2003). A Tabela 3.3 indica valores do fator solar para alguns tipos de vidros.

\begin{tabular}{lcc}
\hline & $\begin{array}{c}\mathbf{F}_{\mathbf{s}} \\
\text { (Somente Vidro) }\end{array}$ & $\begin{array}{c}\mathbf{F}_{\mathbf{s}} \\
\text { (Com esquadria) }\end{array}$ \\
\hline Vidro Simples Transparente $(3 \mathrm{~mm} / 6 \mathrm{~mm})$ & $0,86 / 0,83$ & 0,66 \\
\hline Vidro Simples Cinza $(3 \mathrm{~mm} / 6 \mathrm{~mm})$ & $0,72 / 0,60$ & 0,56 \\
\hline Vidro Simples Verde $(3 \mathrm{~mm} / 6 \mathrm{~mm})$ & $0,71 / 0,60$ & 0,55 \\
\hline Vidro Reflexivo & $0,26-0,37$ & $0,17-0,28$ \\
\hline Vidro Duplo Transparente (câmara de ar de 12,5mm) & 0,76 & 0,59 \\
\hline Vidro Duplo Low-E (e=0,08 / câmara de ar de 12,5mm) & 0,35 & 0,29 \\
\hline
\end{tabular}

Tabela 3.3: Fator Solar para diferentes vidros e elementos de proteção.

Fonte: A partir de DOE/EREC, 1997; FROTA, SCHIFFER, 2003; LAMBERTS et al., 2014.

Conforme se observa nos dados indicados na Tabela 3, o uso de vidros duplos garante um melhor isolamento. Vidros com propriedades de baixa emissividade (ou low-E) reduzem a transmissão de calor, reduzindo o ganho térmico solar, mas permitem a

\footnotetext{
64 Fator Solar (Fs): Soma da transmissão solar direta mais a parcela de energia solar absorvida pelo vidro e re-irradiada para o interior. A última parcela é função das condições ambientais externas e internas (coeficiente de transferência de calor na superfície externa do vidro he $=22,7 \mathrm{~W} / \mathrm{m}^{2} .{ }^{\circ} \mathrm{C}$ e hi=8,3W/m${ }^{2} .{ }^{\circ} \mathrm{C}$ ). A fração da radiação solar com incidência normal que é transferida através do envidraçado diretamente por transmissividade e indiretamente pela energia absorvida que flui para dentro por re-irradiação e convecção para o interior, assumindo que o vento exterior tem velocidade de $2 \mathrm{~m} / \mathrm{s}$ (temperaturas interior e exterior iguais entre si. Informação disponível em http://www.usp.br/fau/deptecnologia/docs/bancovidros/grand.htm\#sectS>, acessada em 15/Fev/2015.
} 
passagem da luz visível. Esses vidros recebem uma camada fina de óxidos metálicos, cuja função principal é reduzir a transmitância térmica $(U)$ da superfície do vidro, suprimindo o fluxo de calor por radiação de onda longa ${ }^{65}$ (DOE/EREC, 1997; IEA, 2013). Trata-se, portanto, de uma alternativa para permitir a iluminação natural contribuindo no controle das trocas de calor.

\subsubsection{Ventilação natural e resfriamento evaporativo}

A ventilação natural é essencial às edificações, pois, além de promover a renovação do ar no ambiente interno, importante para a salubridade, contribui para o conforto térmico em regiões de clima quente e úmido e nos períodos de calor, sendo uma das estratégias indicadas na carta bioclimática. Segundo Serra (1999), a sensação térmica de uma pessoa exposta a uma corrente de ar pode reduzir em torno de $1^{\circ} \mathrm{C}$ para cada $3 \mathrm{~m} / \mathrm{s}$ de velocidade de ar.

A ventilação natural pode ser descrita como o "deslocamento do ar através do edifício, através de aberturas, umas funcionando como entrada e outras como saída" (FROTA, SCHIFFER, 2003, p. 124). As diferenças de pressão do ar entre os ambientes internos e externos influem nesse deslocamento, assim como o dimensionamento e posicionamento das aberturas. Segundo Frota, Schiffer (2003), a ventilação natural pode ser obtida de duas formas distintas:

- Por meio da ação dos ventos, que é provocada pela movimentação do ar através do ambiente devido à força dos ventos;

- Por meio do efeito chaminé, resultante da diferença de densidade do ar.

O efeito chaminé ocorre quando o ar quente, que está mais leve, tem sua exaustão facilitada por aberturas em diferentes níveis da edificação, como aberturas zenitais operáveis, potencializando a circulação do ar no interior, e facilitando a entrada de ar fresco pelas aberturas no pavimento inferior da edificação (DURAN, 2011; LAMBERTS et al., 2014).

Uma estratégia que pode ser adotada conjuntamente à ventilação é o resfriamento evaporativo, que consiste na retirada de calor do ar por meio da evaporação da água ou evapotranspiração das plantas, e é indicada para regiões, ou períodos, quentes e com

65 As camadas de baixa emissividade podem reduzir de 5 a 10 vezes a transferência de calor por radiação de onda longa. Em sistemas de vidros duplos, esta propriedade pode ser adotada no pano de vidro interno para emitir a onda longa de volta ao exterior evitando que aqueça o interior da edificação, ou no pano de vidro externo para reduzir a onda longa que representa perdas de calor do interior para o exterior (LAMBERTS et al., 2014). 
baixa umidade relativa do ar (LAMBERTS et al., 2014). Esta estratégia pode ser aplicada com o uso de fontes, espelhos d'água e massas de vegetação nas proximidades das edificações. Sistemas de aspersão de água também podem ser adotados. A Figura 3.11 ilustra algumas das estratégias para promover a ventilação natural e resfriamento evaporativo em edificações.
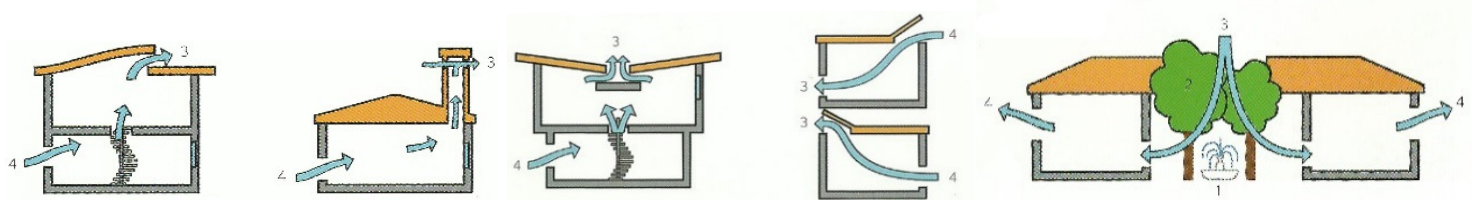

(1) Fonte de água (2) Vegetação (3) Ar quente (4) Ar fresco

Figura 3.11: Diagramas do uso de estratégias de ventilação natural e umidificação. Fonte: DURAN, 2011.

\subsubsection{Estratégias para o conforto térmico no protótipo Ekó House}

O protótipo Ekó House foi desenvolvido visando à participação no SDE 2012, portanto, as premissas e estratégias de projeto foram pensadas considerando as condições climáticas da cidade de Madri. Nos gráficos da Figura 3.12 estão indicadas as médias anuais de temperatura e umidade, e as estratégias de projeto ${ }^{66}$ mais efetivas para Madri.
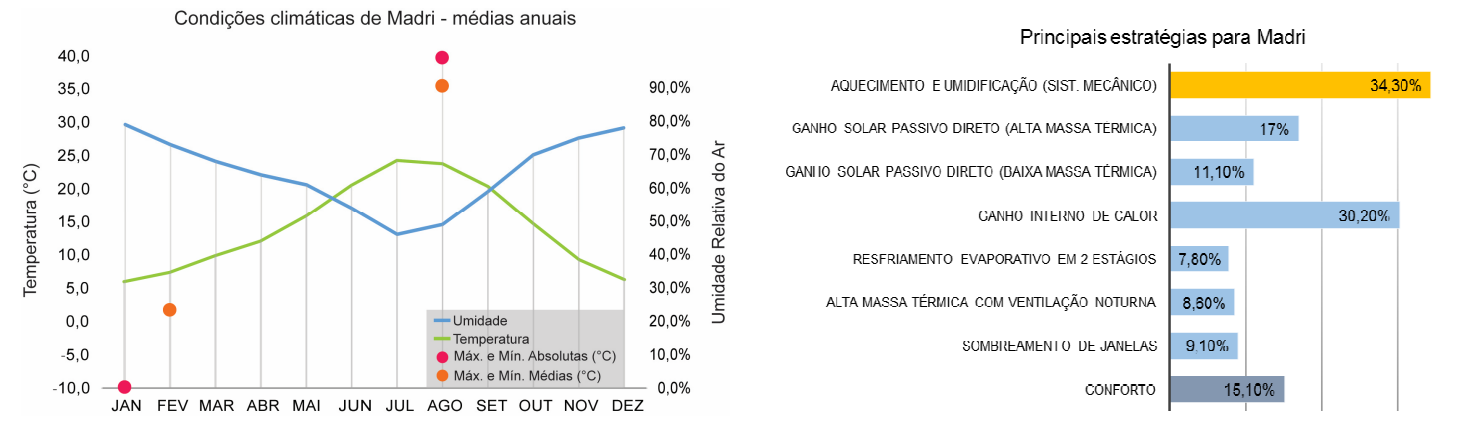

Figura 3.12: Dados climáticos de Madri (à esquerda); e principais estratégias de projeto para Madri, em percentual de horas no ano (à direita).

Fonte: RETScreen®; AEMET, 2014; Climate Consultant 5.5.

Conforme se observa no gráfico das médias de temperatura e umidade relativa de Madri, no verão as máximas são de aproximadamente $35^{\circ} \mathrm{C}$ e no inverno as mínimas estão próximas a $0^{\circ} \mathrm{C}$. Nota-se ainda que no período mais quente há redução na umidade relativa do ar, o que resulta em amplitude térmica, com elevada temperatura durante o dia, e queda na temperatura à noite. As estratégias de aquecimento são

\footnotetext{
66 Estratégias definidas na carta bioclimática gerada na ferramenta computacional Climate Consultant 5.5. Esta ferramenta é descrita em detalhe no Capítulo 4. A carta bioclimática para Madri poder ser consultada no ANEXO 1.
} 
importantes ao longo do ano, mas as altas temperaturas registradas no verão tornam necessário o controle dos ganhos solares passivos, por meio de elementos que protejam as aberturas da incidência direta de radiação solar nesta estação.

As aberturas e proteções solares externas e internas também foram definidas com base no estudo da geometria solar. A fachada orientada a Sul recebeu a maior área de aberturas, que são protegidas por diferentes elementos. O beiral configurado pela projeção do SFV funciona como proteção horizontal acima das aberturas, bloqueando a radiação solar no período do verão, mas permitindo que a radiação incida na fachada durante o inverno. Um sistema de persianas metálicas externas também contribui para evitar a radiação no verão, e por ser um sistema móvel, pode ser recolhido para permitir a incidência de radiação no interior através das aberturas quando desejável.

As fachadas Leste e Oeste são protegidas por painéis móveis de bambu, que servem de fechamento para as varandas e criam uma área de amortecimento térmico. Este fechamento permite permeabilidade visual, pois há espaços vazios entre os bambus. Em função disso, o sombreamento não é pleno, o que reduz a eficácia do sistema durante o verão. Como os painéis são montados sobre trilhos, os ocupantes podem movimentá-los de acordo com a necessidade de insolação ou sombreamento nas fachadas. A fachada Norte, por receber a menor incidência solar durante o inverno torna-se uma superfície propensa a perdas térmicas. Com isso, e também devido à distribuição interna de usos, esta fachada recebeu aberturas menores. Os diagramas e fotografias na Figura 3.13 ilustram as soluções de projeto e proporção entre área de parede e de aberturas para as diferentes orientações de fachadas do protótipo.

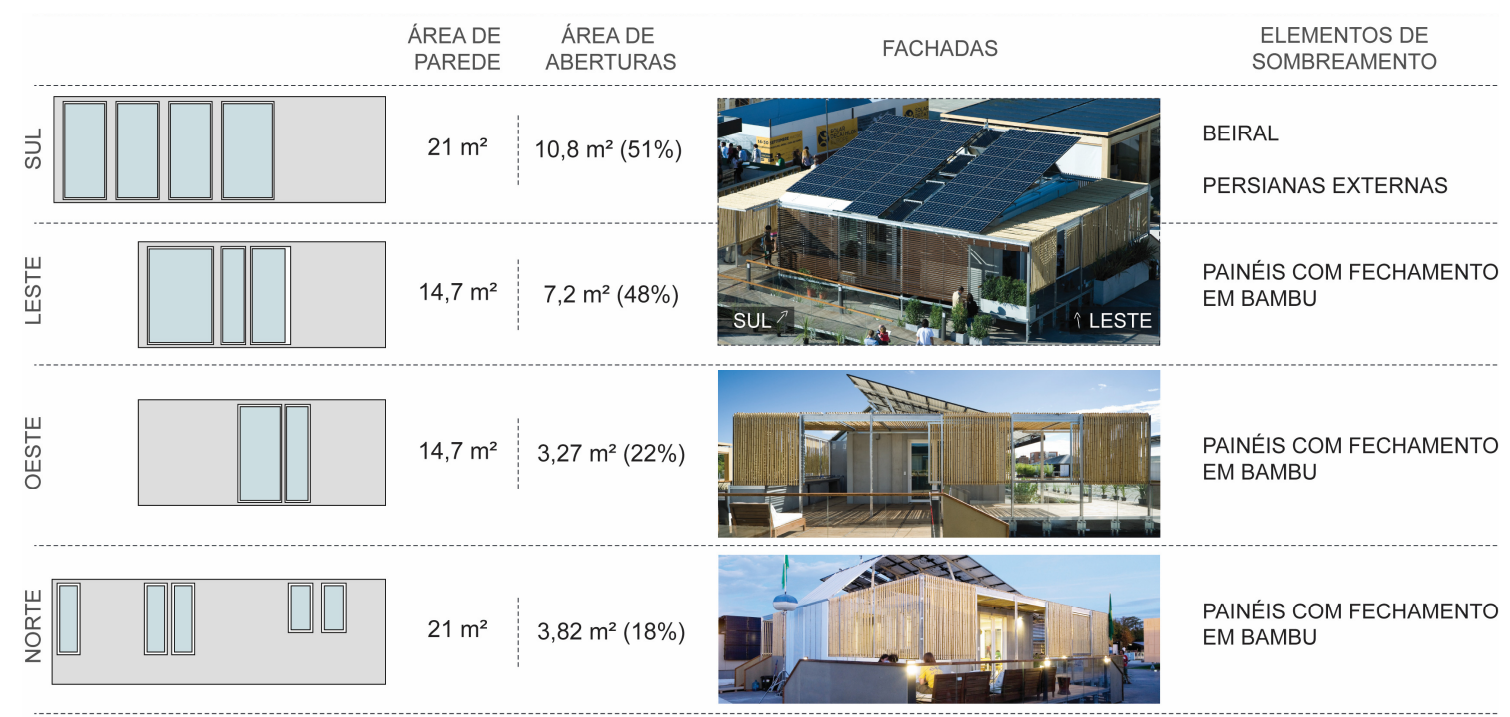

Figura 3.13: Áreas de aberturas e elementos de proteção solar nas fachadas do protótipo Ekó House. Fonte: Própria a partir de Projeto Ekó House, 2012. Fotografias: CI+D+Art/SDE 2012. 
O isolamento térmico foi priorizado como forma de aumentar a eficiência do sistema de condicionamento artificial, em detrimento do uso de materiais com alta inércia térmica, também indicado como importante estratégia. Neste caso, a escolha dos materiais e do sistema construtivo atendeu também a requisitos de montagem, desmontagem e transporte do protótipo. Isso condicionou o projeto da envoltória, composta por painéis pré-fabricados combinados com elementos de revestimento que permitem, além da sobreposição de várias camadas de isolantes térmicos, a associação de instalações prediais (eletricidade, água, automação, entre outras). $O$ isolamento enquanto estratégia contribui na redução perdas térmicas através do envelope e também para evitar ganhos térmicos nos períodos de calor.

Com estas soluções para os componentes construtivos e materiais empregados, 0 isolamento térmico do protótipo alcança níveis satisfatórios. O gráfico da Figura 3.14 compara os valores de transmitância térmica do protótipo Ekó House com os de materiais geralmente utilizados nas construções brasileiras.

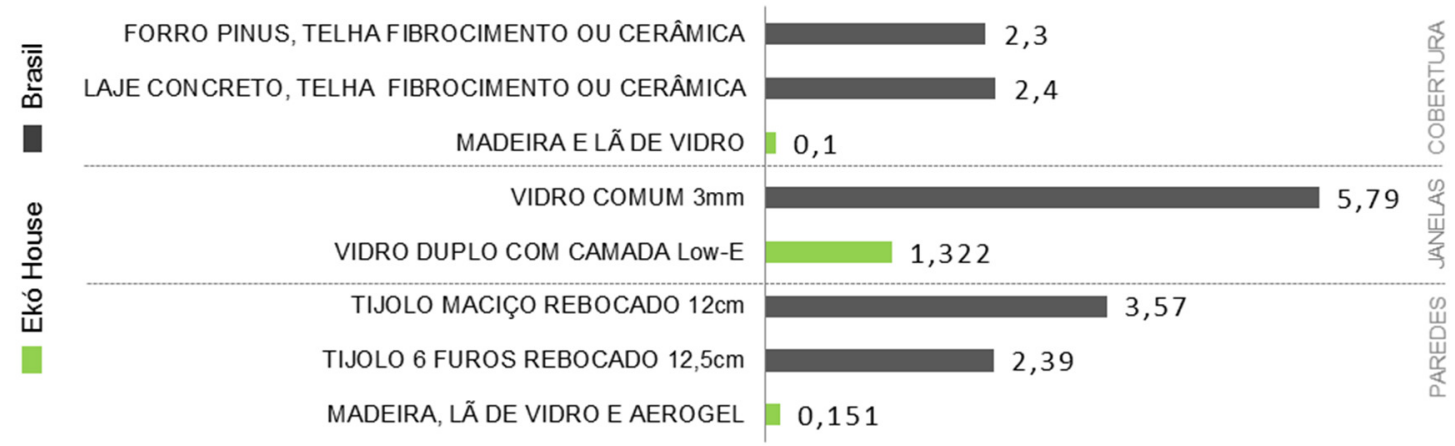

Figura 3.14: Valores de transmitância térmica $\left(\mathrm{kW} / \mathrm{m}^{2} \mathrm{~K}\right)$ para diferentes materiais de vedação largamente utilizados em unidades habitacionais brasileiras e no protótipo Ekó House.

Fonte: A partir de Projeto Ekó House, 2012; Lamberts et al, 1997.

A ventilação natural no interior do protótipo é favorecida devido à disposição de aberturas nas quatro fachadas, combinada a um ambiente interno integrado. Além disso, como algumas das esquadrias possuem diferentes regulagens, por meio de um sistema oscilo batente, os ocupantes podem controlar facilmente a ventilação natural no interior da edificação.

O protótipo conta ainda com um sistema de radiadores a água para aquecimento do ambiente quando necessário, e também com um sistema de resfriamento evaporativo que associa ventilação forçada e umidificação. Mais detalhes sobre estes sistemas e também sobre a montagem e especificações técnicas dos elementos de vedação podem ser encontrados em Kokubun (2014) e Projeto Ekó House (2012). 
De acordo com o regulamento do SDE 2012, as maiores pontuações de conforto térmico eram obtidas quando a temperatura no interior do protótipo estivesse entre $23^{\circ} \mathrm{C} \mathrm{e} 25^{\circ} \mathrm{C}$. Durante a competição, foram realizadas medições diárias da temperatura e umidade relativa do ar no interior do protótipo. Durante dois dias, estes parâmetros foram medidos na ausência do uso de equipamentos mecânicos, de modo a verificar o conforto obtido por meio das estratégias passivas adotadas. Neste período a temperatura se manteve majoritariamente dentro da faixa de conforto estabelecida, mas atingindo níveis mais baixos em períodos específicos, durante a madrugada e próximo às $16 \mathrm{~h}$ da tarde.

Os radiadores à água, que constituem um sistema passivo, não estavam sendo utilizados, mas provavelmente teriam evitado estas quedas de temperatura durante as medições. A temperatura interna excedia os $25^{\circ} \mathrm{C}$ nos horários de visitação pública ${ }^{67}$, mas, de modo geral, a temperatura interna se manteve na faixa de maior conforto definida pelo regulamento do SDE 2012 (entre $23^{\circ} \mathrm{C}$ e $25^{\circ} \mathrm{C}$ ), o que demonstra a eficácia das estratégias passivas adotadas no período em questão. Os valores das medições estão indicados nos gráficos da Figura 3.15.

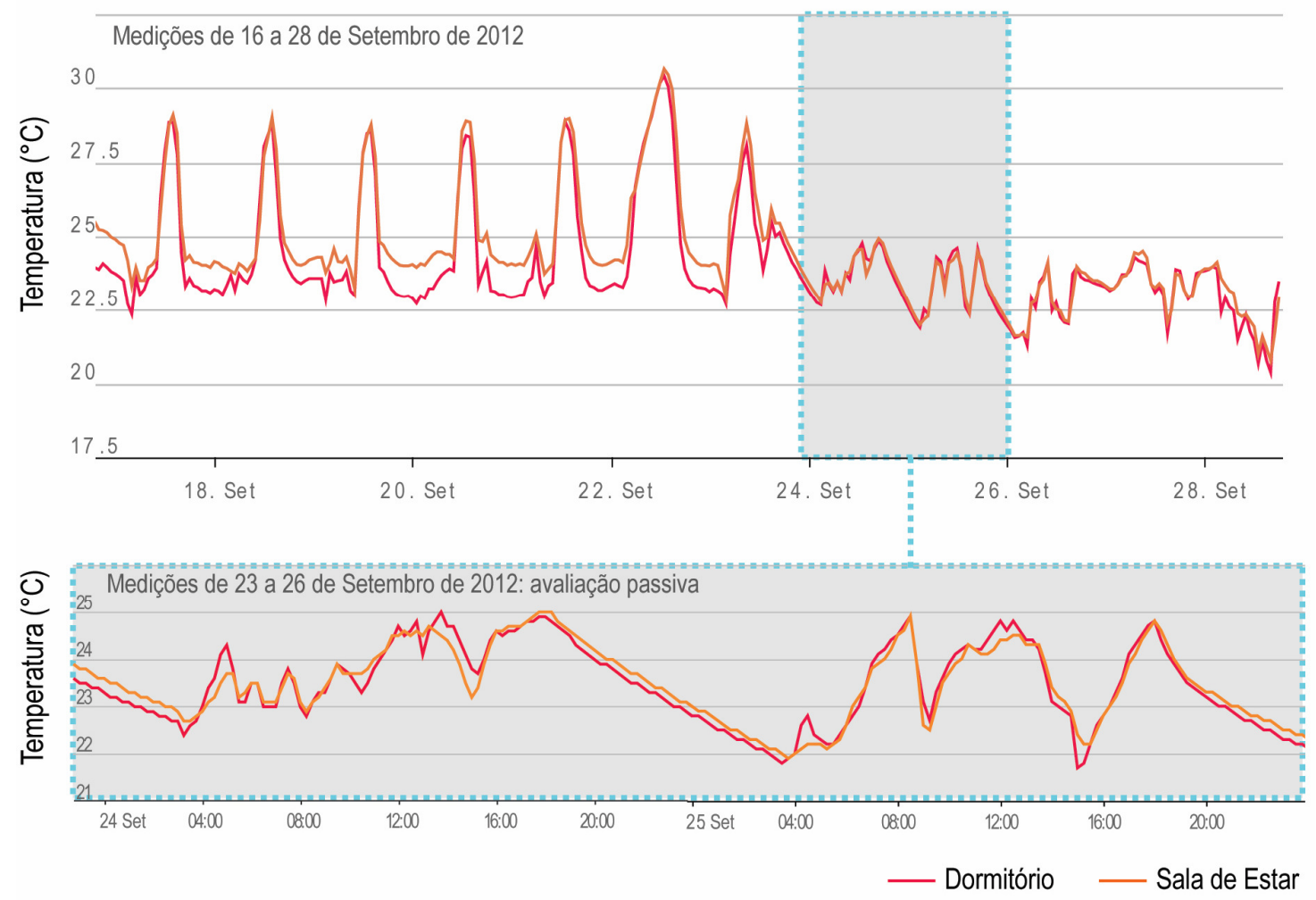

Figura 3.15: Medições de temperatura no interior do protótipo Ekó House durante o SDE 2012. Fonte: Elaborado a partir de dados disponibilizados por SDE, 2014.

67 Nos horários de visitação, as portas eram abertas constantemente, e havia a presença de até 3 grupos de visitantes, com cerca de 12 pessoas cada, simultaneamente no interior do protótipo, o que ocasionava o aumento na temperatura interna. 
Com relação à umidade relativa do ar, em poucos períodos este nível esteve abaixo dos $25 \%$ ou acima dos $60 \%$, limites estabelecidos pelo regulamento do concurso. No entanto, sem o sistema de resfriamento evaporativo em funcionamento durante a competição, em alguns períodos o nível de umidade ficou abaixo dos $40 \%$, considerado limite inferior ótimo. O gráfico da Figura 3.16 indica os valores de medições.

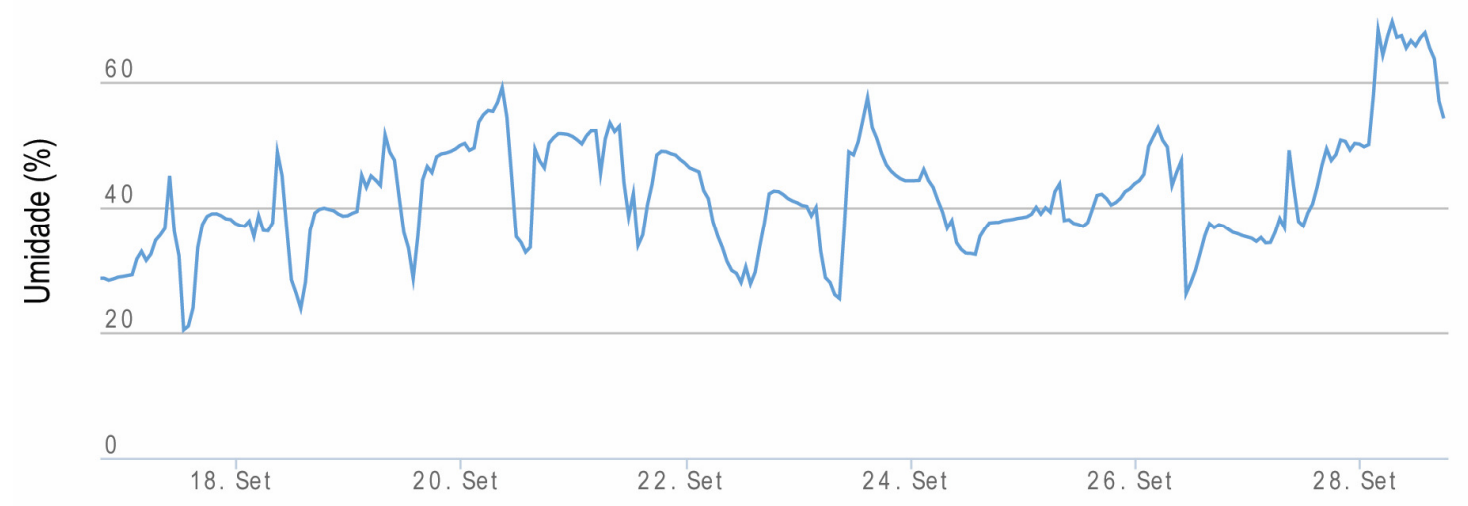

Figura 3.16: Valores de medição de temperatura e umidade relativa do ar no interior do protótipo Ekó House durante sua participação no SDE 2012.

Fonte: Elaborado a partir de dados disponibilizados por SDE, 2014.

\subsection{Estratégias para o conforto visual}

A iluminação é um aspecto de extrema importância nas edificações, que influi na percepção das formas e superfícies edificadas e, consequentemente, na qualidade plástica das edificações. A iluminação natural possibilita notar as variações das horas do dia e do clima exterior, conforme muda a luz. Ambientes sombrios ou sem vistas ao exterior são geralmente considerados insatisfatórios pelos ocupantes (BSI, 2008).

A iluminação natural, assim como a insolação, exerce influência sobre a saúde e o bemestar dos ocupantes, por exemplo, na regulação do sistema circadiano e no humor, e também contribui para a salubridade dos ambientes, já que a exposição ao sol pode eliminar vírus e bactérias (BSI, 2008). A luz influi na aparência do ambiente interno, por meio de uma iluminação geral, e na realização de tarefas visuais, que requerem níveis específicos de iluminação. Para atender à demanda por iluminação no ambiente interno, iluminação natural e artificial devem ser combinadas, visando ao conforto visual dos ocupantes e à eficiência no consumo de energia elétrica. 


\subsubsection{Iluminação Natural}

Nas edificações, a luz natural pode ser obtida basicamente por três fontes. O sol fornece luz através de radiação direta, o céu provê luz difusa, e as superfícies podem prover luz refletida ou indireta (LAMBERTS et al., 2014). A luz do sol e a luz do céu são ambas importantes, mas diferem muito em suas características. Enquanto a luz do sol resulta em altos níveis de iluminância ${ }^{68}$, ocasionando contraste acentuado, a luz do céu, difusa, pode resultar em uma iluminação mais homogênea, sem contraste excessivo entre distintos pontos em um mesmo ambiente, ou entre o interior e o exterior de uma edificação (BSI, 2008).

A luz do céu, quando utilizada na iluminação geral de um ambiente, deve ser bem distribuída e ser tal que não haja um contraste expressivo entre interior e exterior (BSI, 2008). O estudo da disponibilidade de luz natural considera a luz do céu, que apresenta basicamente três condições, que são céu claro, céu parcialmente encoberto, e céu encoberto, sendo que em projetos de iluminação geralmente se aplica esta última por ser a condição com mais baixa disponibilidade de luz (LAMBERTS et al., 2014).

No estudo do aproveitamento da iluminação natural, é importante conceituar o Fator de Luz Diurna (FLD), denominado por alguns autores como Contribuição da lluminação Natural (CIN), que é a razão entre o nível de iluminação interior e o exterior (ABNT, 2005; CORBELLA, 2003; IESNA, 2004; LAMBERTS et al., 2014). Esta razão é expressa em um valor percentual, portanto, uma CIN de $5 \%$ indica que em um ambiente interno, para um ponto específico, a iluminância será de 500 lux quando a iluminância do céu for de 10.000 lux (LAMBERTS et al., 2014).

$$
\mathrm{FLD}=\left(\mathrm{E}_{\text {int }} / \mathrm{E}_{\mathrm{ext}}\right) \times 100(\%)
$$

Eint: iluminância em um determinado ponto de um plano horizontal do ambiente interno (lux);

Eext: iluminância produzida pela abóboda celeste sobre um plano horizontal externo, excluindo-se a iluminação direta do sol (lux).

Equação 3.1: Fator de Luz Diurna.

Fonte: ABNT, 2004; CORBELLA, 2003; LAMBERTS et al., 2014.

Este percentual de iluminação que estará disponível no interior varia conforme o tamanho e a localização das aberturas, as obstruções do céu, as propriedades dos fechamentos transparentes à luz, e também em função das refletâncias das superfícies

68 Iluminância é a medida da intensidade de luz que atinge uma superfície. Especificamente, é a concentração do fluxo luminoso incidente, medido em lux. Sendo assim, a iluminância se refere a uma quantidade de luz incidindo sobre uma superfície, ou à densidade superficial do fluxo luminoso incidente num ponto sobre uma superfície (BROWN, DEKAY, 2004; IESNA, 2000). 
interiores (BROWN, DEKAY, 2004). Segundo ABNT (2005) e Corbella (2003), o fluxo luminoso do exterior pode chegar a um ponto no interior de uma edificação basicamente de três diferentes formas, conforme descrito a seguir e ilustrado na Figura 3.17:

- Por meio da porção de céu vista pelo observador, que é a luz que alcança um ponto do ambiente interno proveniente diretamente do céu, definida como Componente do Céu (CC);

- A luz que chega ao interior após ter sido refletida por superfícies externas, definida como Componente Refletida Externa (CRE);

- A luz que é refletida pelas superfícies do próprio ambiente interno, sendo determinada pela forma, disposição e cores dessas superfícies, e definida como Componente Refletida Interna (CRI)
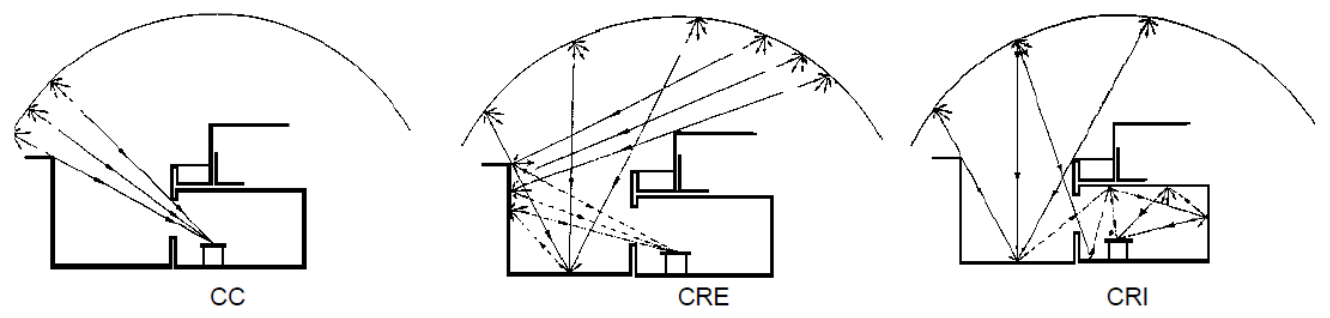

Figura 3.17: Componentes CC, CRE e CRI, que caracterizam as diferentes formas da luz natural alcançar um determinado ponto no interior de uma edificação. Fonte: ABNT, 2004.

Diversas são as estratégias que podem ser adotadas para o aproveitamento da iluminação natural em edificações. A dimensão, proporção, distribuição e posicionamento das aberturas influem tanto quantitativa quanto qualitativamente na iluminação natural interior (LAMBERTS et al., 2014; HASTINGS, WALL, 2009).

A geometria também exerce importante influência no acesso à iluminação natural no interior das edificações. Considerando apenas a presença de aberturas em fachadas, uma distância de até 5 metros pode ser iluminada naturalmente, e as distancias mais profundas são apenas parcialmente iluminadas (LAMBERTS et al., 2014). Desta forma, para uma mesma área total construída, diferentes geometrias podem permitir um maior ou menor acesso à iluminação natural, conforme demonstram os diagramas da Figura 3.18 . 


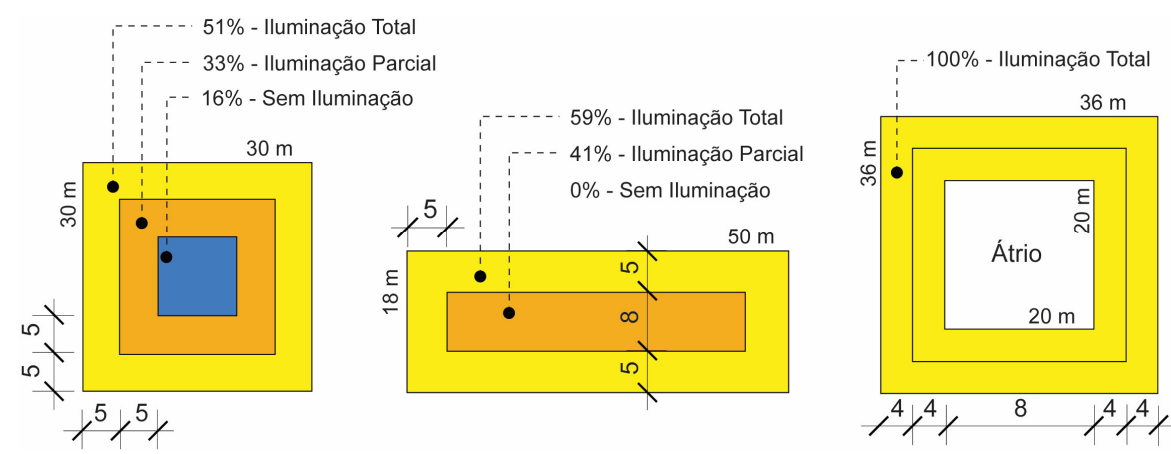

Figura 3.18: Acesso à iluminação natural em função da geometria em planta da edificação. Fonte: A partir de LAMBERTS et al., 2014.

A iluminância em um ambiente aumenta com o tamanho das aberturas. A Razão JanelaParede (RJP) expressa o valor percentual da área líquida de uma abertura dividida pela área da parede que a contém. Hastings, Wall (2009) demonstram em um estudo que, para RJP de até 50\%, o aumento da iluminação no interior varia proporcionalmente com o aumento da área da abertura. A partir de uma RJP de $50 \%$ os ganhos em termos de iluminação natural deixam de ser tão significativos, conforme demonstra o gráfico da Figura 3.19.

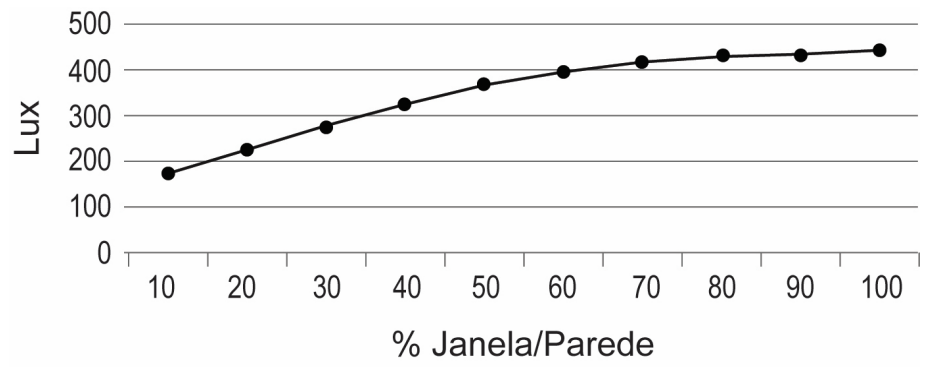

Figura 3.19: Relação entre iluminação natural e a Razão Janela-Parede.

Fonte: HASTINGS, WALL, 2009.

O uso de janelas em fachadas opostas de um mesmo ambiente é uma estratégia que, quando possível de ser adotada, contribui para uma distribuição mais uniforme da luz natural no interior das edificações, reduzindo contraste e ofuscamento. A orientação também influencia a qualidade da iluminação natural. Considerando uma edificação no Hemisfério Sul, as aberturas orientadas a Norte receberão uma incidência solar continua ao longo do dia, além de ser uma orientação facilmente sombreada por elementos horizontais. O mesmo ocorre com a incidência de luz nas aberturas orientadas a Sul, pois há uma constância na iluminação, além de ser a orientação com mais baixa incidência de radiação direta e, portanto, menos propensa a problemas de contraste e ofuscamento. Os gráficos na Figura 2.20 demonstram as curvas de iluminação no interior para o caso de aberturas unilaterais, e a variação da iluminação nas diferentes orientações. 


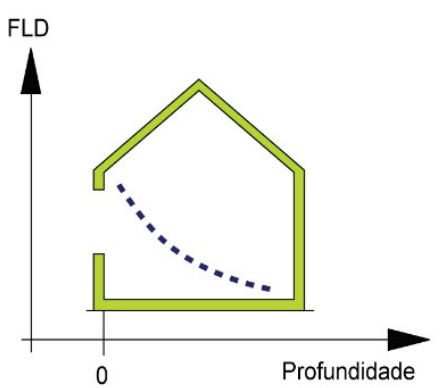

(a) FLD conforme profundidade do ambiente
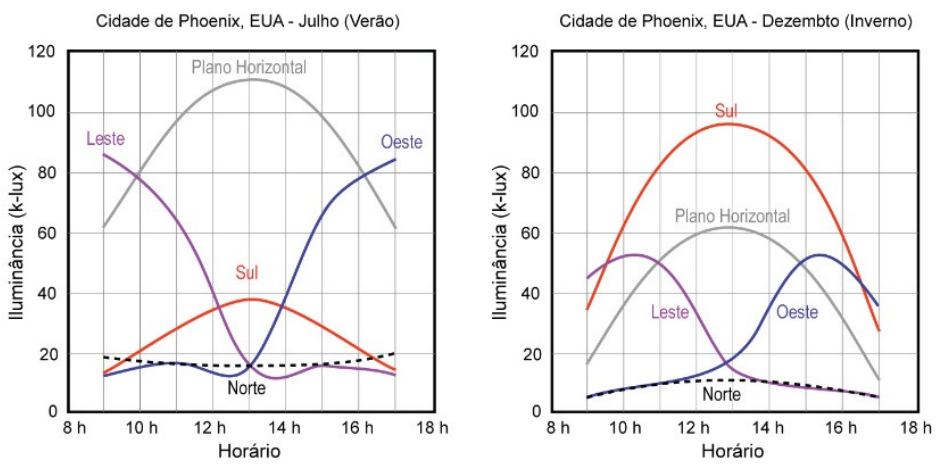

(b) lluminâcia média para diferentes orientações ao longo do dia (no Hemisfério Norte)

Figura 3.20: Variação da iluminação natural conforme a profundidade do ambiente e orientação das aberturas.

Fonte: A partir de CORBELLA, 2003; BROWN, DEKAY, 2004.

Para o aproveitamento da iluminação natural, diferentes soluções podem ser adotadas.

As prateleiras de luz são dispositivos horizontais que podem ser acoplados às janelas, contribuem para sombrear parte da abertura, e permitem uma maior penetração da luz natural no interior da edificação, por meio da reflexão da luz que neles incide para o teto do ambiente interno, o que favorece o aproveitamento da CRI (BROWN, DEKAY, 2004; CORBELLA, 2003). Estes elementos também podem evitar situações de desconforto e cansaço visual por contraste e ofuscamento (BROWN, DEKAY, 2004). A Figura 3.21 ilustra este sistema.

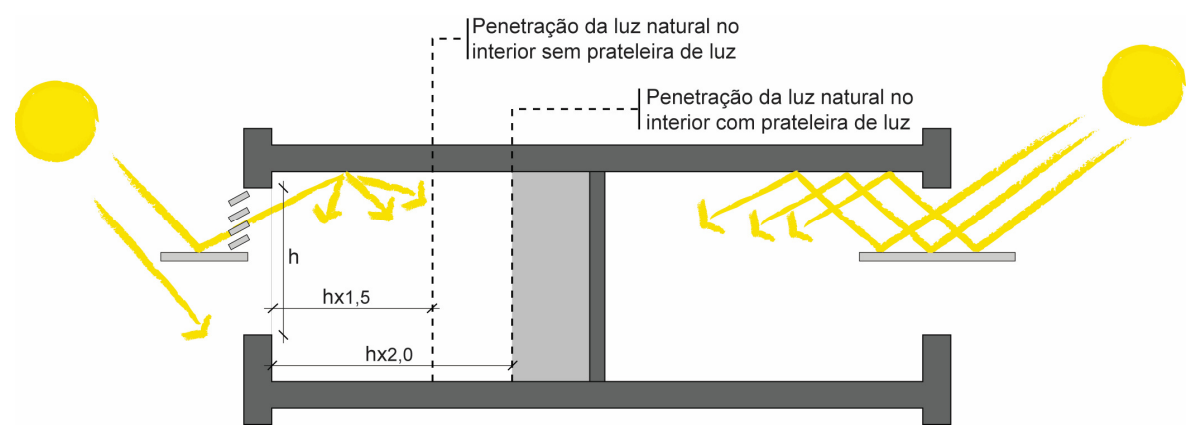

Figura 3.21: Prateleiras de luz e o aumento da penetração da iluminação natural no ambiente interno. Fonte: Adaptado CORBELLA, 2003; LAMERTS et al., 2014.

A iluminação zenital ${ }^{69}$ é uma estratégia que provê uma distribuição mais uniforme da iluminação no ambiente interno quando comparada à iluminação lateral. No caso de sua aplicação em regiões de clima tropical, é indicado que as aberturas zenitais sejam protegidas ou orientadas de modo a evitar ganhos térmicos excessivos por radiação solar direta (CORBELLA, 2003). Neste caso, projetos que favoreçam o aproveitamento

69 lluminação zenital pode ser definida como a porção de luz natural que entra nos espaços internos através de aberturas superiores (LAMBERTS et al., 2014). 
da $\mathrm{CRI}$ podem contribuir para evitar ganhos térmicos e para uma iluminação mais uniforme.

Soluções como mansardas, domos, sheds são exemplos de iluminação zenital aproveitando a CC. Já os tubos de luz são elementos capazes de conduzir a iluminação natural por um tubo até o interior da edificação. A superfície interior do tubo de luz possui uma refletividade de até $98 \%$, tornando estes sistemas altamente eficientes e, ao atingir o final do tubo, um elemento difusor distribui a luz no ambiente interior. A Figura 3.22 ilustra diferentes soluções para o uso da iluminação zenital.

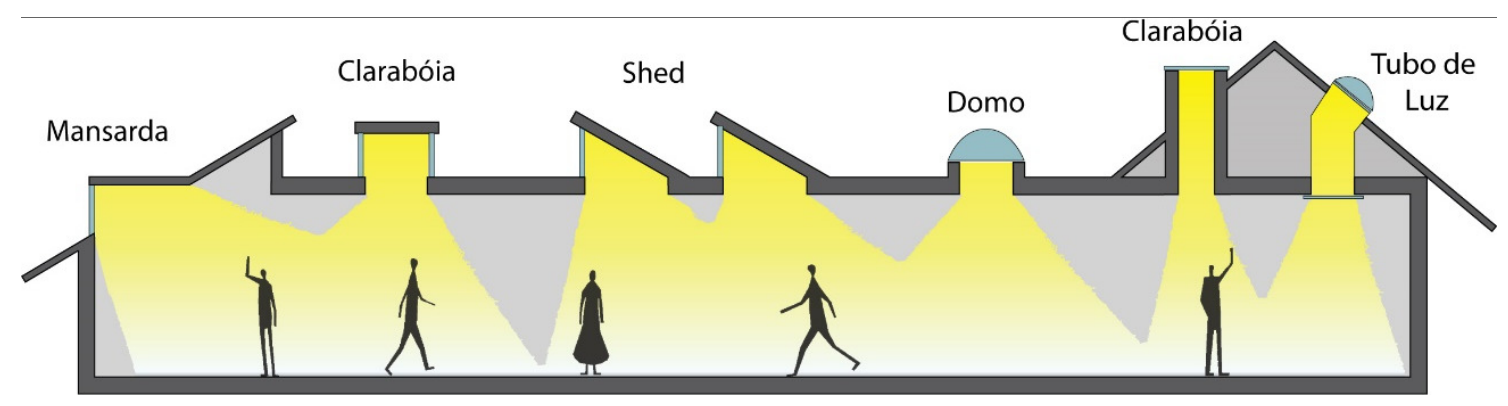

Figura 3.22: Estratégias para aproveitamento da iluminação zenital em edificações. Fonte: Elaborado a partir de Corbella, 2003; Duran, 2011; Hastings, Wall, 2009; Lamberts et al., 2014.

A luz do sol pode e deve ser aproveitada, no entanto, é importante que as estratégias para aproveitamento deste recurso estejam devidamente integradas às demais estratégias para provisão de conforto ambiental. Corbella (2003) aponta a importância de se evitar uma demasiada incidência de radiação solar direta nos projetos de iluminação em edificações localizadas em zonas tropicais. Elementos de sombreamento externos e internos podem ser aplicados para contribuir na adequação dos níveis de iluminação no interior da edificação, conforme exemplos demonstrados no item 3.5.1.

O uso sensível da iluminação natural juntamente com adequados elementos para controlar a incidência direta do sol e os níveis de iluminação no interior devem ser considerados parte integrante de um projeto solar passivo (BSI, 2008). Diferentemente das tipologias multifamiliares, onde as possibilidades de aberturas são geralmente apenas nas fachadas, a tipologia habitacional unifamiliar apresenta grande flexibilidade para integração de diferentes estratégias e sistemas para o aproveitamento da iluminação natural, qualificando o ambiente interno e promovendo o conforto visual e a eficiência no consumo de energia. 


\subsubsection{Iluminação Artificial}

Um bom projeto de iluminação artificial deve ser desenvolvido de forma complementar ao aproveitamento da iluminação natural disponível em um determinado ambiente. 0 projeto de iluminação artificial compreende diferentes etapas, que incluem a identificação dos níveis de iluminação necessários; a percepção das características do local a ser iluminado, como cores, tipos de superfícies e suas dimensões; a escolha das luminárias e das lâmpadas e suas características técnicas; para então realizar o cálculo e determinar o número de pontos de luz (CORBELLA, 2003). A NBR 5413 (ABNT, 1992) indica os níveis de iluminância requeridos por classes de tarefas, conforme demonstrado na Tabela 3.4.

\begin{tabular}{lcl}
\hline & Iluminância (Lux) & \multicolumn{1}{c}{ Tipo de atividade } \\
\hline $\begin{array}{l}\text { (A) lluminação geral para áreas } \\
\text { utilizadas interruptamente ou com tarefas } \\
\text { visuais simples }\end{array}$ & $100 / 150 / 200$ & $\begin{array}{l}\text { Recintos não usados para trabalhos } \\
\text { contínuos }\end{array}$ \\
\cline { 2 - 3 } $\begin{array}{l}\text { (B) lluminação geral para área de } \\
\text { trabalho }\end{array}$ & $500 / 300 / 500$ & $\begin{array}{l}\text { Tarefas com requisitos visuais } \\
\text { limitados }\end{array}$ \\
\hline
\end{tabular}

Tabela 3.4: Iluminância por classe de tarefas visuais que se aplicam ao uso residencial. Fonte: A partir de ABNT, 1992.

Lamberts et al. (2014) observa que os ocupantes acionam facilmente a iluminação artificial quando necessário, mas dificilmente desligam este sistema quando já não há mais necessidade de usá-lo, devido ao fato de que os olhos adaptam-se facilmente a quantidades de iluminância mais altas do que o necessário. Neste caso, sistemas automáticos podem ser adotados para contribuir no controle da iluminação artificial e evitar desperdício de energia elétrica. São exemplos os sensores fotoelétricos, os dimerizadores, sensores de presença e programadores de tempo.

Outra importante estratégia para a eficiência de sistemas de iluminação artificial é a adoção de circuitos elétricos independentes. Estes circuitos podem ser definidos de acordo com a disponibilidade de luz natural no ambiente interno, por exemplo, segundo o FLD (CORBELLA, 2003). Ressalta-se ainda que os valores indicados na Tabela 3.4 são de uma norma do ano de 1992, portanto, é importante atentar às alternativas que surgiram nos últimos anos para se obter os níveis de iluminância adequados com maior eficiência energética. A iluminação de tarefa, por exemplo, é uma maneira eficiente de utilizar a iluminação artificial de forma complementar à natural e facilitar a autonomia do usuário, que poderá controlar a iluminação artificial conforme sua demanda, e independentemente da iluminação geral do ambiente. Isso confere maior flexibilidade e racionalidade no uso do sistema de iluminação artificial. Além disso, esta forma de 
iluminação pode ser adotada para prover a iluminação necessária no posto de trabalho sem que seja necessário prover uma iluminância mais elevada em todo o ambiente.

É também importante conhecer as diferentes tecnologias de iluminação artificial disponíveis no mercado e o impacto que elas podem ter no consumo de energia, no calor dissipado ao ambiente interno, na qualidade da iluminação e na necessidade de manutenção do sistema.

"Lâmpadas incandescentes convertem apenas $10 \%$ de sua potência elétrica em luz, sendo que $90 \%$ se transforma em calor, dos quais $80 \%$ se dissipa por radiação e $10 \%$ por condução e convecção. Lâmpadas fluorescentes convertem $25 \%$ de sua potência elétrica em luz, sendo $25 \%$ dissipado, sob forma de calor radiante, para as superfícies circundantes e $50 \%$ dissipado por condução e convecção. O reator da lâmpada fluorescente fornece mais $25 \%$ da potência nominal da lâmpada sob forma de calor para o ambiente" (FROTA, SCHIFFER, 2003, p. 122).

Os sistemas LED (Light Emitting Diodes ${ }^{70}$ ) vêm alcançando uma maior penetração no mercado e oferecem uma série de vantagens em relação às lâmpadas incandescentes e lâmpadas fluorescentes compactas (LFC). O LED é mais eficiente no consumo de energia, possui uma vida útil mais extensa, não contem mercúrio - elemento tóxico presente nas LFC, emite menos calor e requer menor manutenção (DOE, 2012; STIRLINGLED, 2014). A Tabela 3.5 compara características do LED, LFC e lâmpadas incandescentes.

\begin{tabular}{lcccc}
\hline $\begin{array}{c}\text { Tipo de } \\
\text { Lâmpada }\end{array}$ & $\begin{array}{c}\text { Potência } \\
\text { (W) }\end{array}$ & Lumens & $\begin{array}{c}\text { Vida Útil } \\
\text { (Horas) }\end{array}$ & $\begin{array}{c}\text { Consumo de Energia } \\
\text { (MJ/20 milhões de lumen-horas) }\end{array}$ \\
\hline Incandescente & 60 & 900 & $1 \mathrm{mil}$ & $15,1 \mathrm{mil}$ \\
\hline LFC & 15 & 900 & $8,5 \mathrm{mil}$ & $3,78 \mathrm{mil}$ \\
\hline LED & $12,5-5,8$ & 800 & 25 a $45 \mathrm{mil}$ & 3,5 a $1,6 \mathrm{mil}$ \\
\hline
\end{tabular}

Tabela 3.5: Diferenças entre os sistemas de iluminação artificial.

Fonte: DOE, 2012.

Estratégias de projeto apropriadas, adequado aproveitamento da iluminação natural e tecnologias eficientes podem contribuir na redução do consumo de energia por parte de sistemas de iluminação artificial. Desta forma, é possível atender às demandas dos ocupantes, satisfazendo os parâmetros de conforto visual com eficiência energética.

\footnotetext{
70 Diodos emissores de luz.
} 


\subsubsection{Estratégias para o conforto visual no protótipo Ekó House}

A premissa de aproveitamento da luz natural como fonte principal para iluminação determinou a distribuição dos ambientes internos do protótipo. Sendo o banheiro o único ambiente compartimentado por vedações verticais, os demais ambientes da casa são integrados, formando um espaço fluido, único que se beneficia do fluxo luminoso que atravessa as grandes aberturas nas fachadas. Todos os espaços da casa recebem iluminação natural, que varia ao longo do dia. O sistema de iluminação artificial é projetado de modo a complementar o uso da iluminação natural (PROJETO EKÓ HOUSE, 2012).

\subsubsection{Iluminação natural no protótipo Ekó House}

A geometria adotada no partido arquitetônico mostra-se bastante favorável ao aproveitamento da iluminação natural no interior do protótipo. A planta retangular com as maiores fachadas orientada a Norte e Sul, bem como a integração e fluidez do ambiente interno, são aspectos que beneficiam o acesso à luz natural no interior.

Conforme mencionado no item 3.5.3, a maior área de aberturas se encontra na fachada Sul, provendo iluminação natural principalmente para os ambientes da sala de jantar e cozinha, que ainda recebem iluminação natural pela abertura na fachada Oeste. Estas aberturas contribuem para a iluminação nos planos da mesa de jantar, nas bancadas da cozinha, e na mesa de trabalho, alocada junto às aberturas da fachada Sul. A cozinha conta ainda com duas aberturas menores na fachada Norte. O dormitório e sala de estar possuem aberturas localizadas na fachada Leste, e se beneficiam do sol da manhã. $O$ dormitório conta ainda com duas aberturas menores na fachada Norte, e o banheiro é iluminado por uma abertura também na fachada Norte.

Os elementos de proteção externa já referidos - beiral formado pela projeção do SFV, persianas da fachada Sul e elementos em bambu das fachadas Leste, Oeste e Norte possibilitam diferentes ajustes, adequando os níveis de iluminação a necessidades especificas dos ocupantes. As persianas externas da fachada Sul podem ser completamente recolhidas, permitindo uma maior penetração de luz natural no interior do protótipo. Por serem reguláveis e pivotantes no eixo horizontal, podem ser ajustadas para bloquear a radiação solar direta, e permitir a entrada de luz difusa no interior. As fotografias (a), (b) e (c) na Figura 3.23 ilustram estes diferentes ajustes das persianas. 
As varandas com fechamento em bambu, presentes nas fachadas Leste, Oeste e Norte, também contribuem para a proteção contra a incidência direta do sol nestas fachadas. Mas, conforme já mencionado, não permitem um bloqueio completo da radiação solar, o que limita as possibilidades de adequação deste sistema a necessidades específicas dos ocupantes. A fotografia (d) na Figura 3.23 ilustra a permeabilidade ao sol destes elementos. Internamente, o protótipo conta com cortinas translúcidas e de cor clara, que contribuem no controle dos níveis de iluminação no interior. A fotografia (e) na Figura 24 ilustra estas cortinas.

No que tange ao aproveitamento da iluminação natural, observa-se um conflito no projeto devido ao uso do fechamento em bambu na fachada Norte, pois estes elementos bloqueiam a radiação difusa (luz do céu), reduzindo a iluminação natural no interior. Como não há incidência de radiação solar direta nesta fachada, estes elementos cumprem função estética e de configuração do espaço externo, mas reduzem a iluminação natural nas aberturas orientadas a Norte. Além dos elementos de bambu, o gabinete técnico obstrui a luz do céu, comprometendo principalmente a abertura do banheiro. A fotografia (f) na Figura 3.23 ilustra estes elementos no protótipo Ekó House. O reposicionamento desses elementos (quadros de bambu e gabinete técnico) poderia atender mais satisfatoriamente o requisito de iluminação natural no banheiro. Isso demandaria novos arranjos das instalações prediais, com impactos em todo o sistema de geração e controle de energia fotovoltaica e solar térmica. 


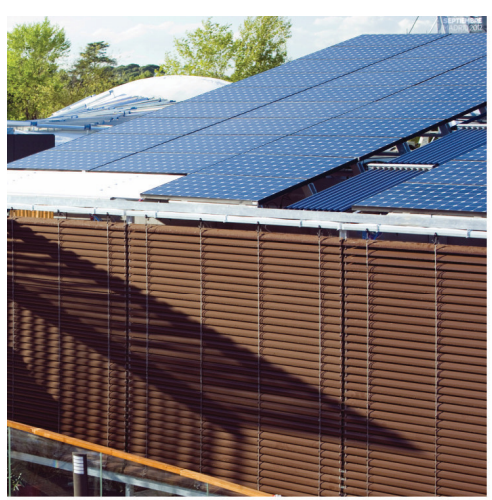

(a) Persianas fechadas

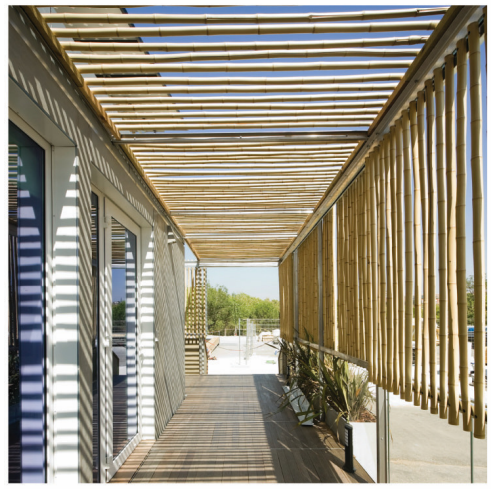

(d) Painéis de bambu: espaçamento não permite bloquei completo da radiação

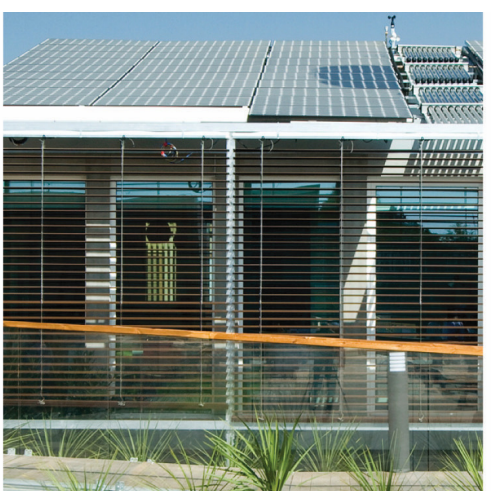

(b) Persianas abertas e abaixadas

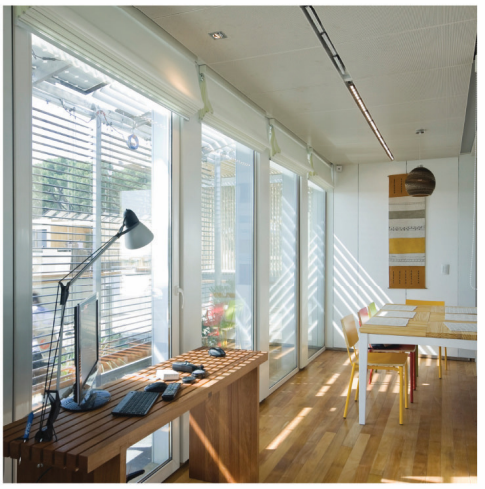

(e) Persianas internas recolhidas

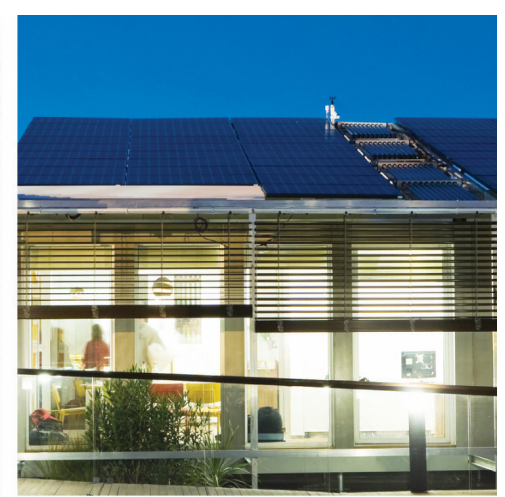

(c) Persianas sendo recolhidas

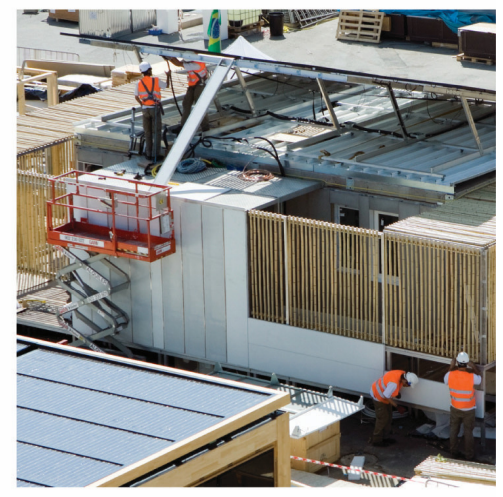

(f) Elementos de bambu e Gabinete Técnico na fachada Norte

Figura 3.23: Diferentes elementos de sombreamento utilizados no protótipo Ekó House. As fotografias (a), (b) e (c) ilustram diferentes posições para as persianas da fachada Sul; (d) ilustra a permeabilidade dos quadros de bambu; (e) ilustra as persianas internas, que podem ser completamente recolhidas para maior aproveitamento da iluminação natural; e (f) ilustra os elementos que obstruem a iluminação natural na janela do banheiro.

Fonte: Elaborado a partir de fotografias de @I+D+Art/SDE 2012.

Durante o SDE 2012 o protótipo apresentou bom desempenho na avaliação de iluminação. De acordo com simulações computacionais realizadas para o projeto, a autonomia de luz do dia $^{71}$ é de cerca de $60 \%$ e, mesmo com os dispositivos de sombreamento fechados, é possível atingir níveis adequados de iluminação para as atividades dos usuários apenas utilizando iluminação natural durante a maior parte do ano. Esse desempenho foi refletido nas medições de iluminação feitas na área de trabalho, que resultou na pontuação de 17,85 para um máximo de 20 pontos (OLIVEIRA, 2013).

\subsubsection{Iluminação artificial no protótipo Ekó House}

O projeto de iluminação artificial para a Ekó House foi desenvolvido de modo a complementar o aproveitamento da iluminação natural. É adotado um sistema linear de

\footnotetext{
${ }^{71} \mathrm{~A}$ autonomia de luz do dia se refere à quantidade de tempo que se espera atender a certos níveis de luminosidade somente utilizando iluminação natural.
} 
luminárias no forro, condizente com a integração e fluidez do ambiente interno, e que resulta em uma iluminação uniforme no interior do protótipo.

Complementarmente a este sistema, são utilizadas luminárias para uma iluminação direcional, focando áreas específicas, como a bancada de trabalho, que conta também com uma luminária de mesa. São utilizadas ainda luminárias confeccionadas artesanalmente pela equipe Team Brasil com o intuito de obter uma iluminação cênica e direcionada a pontos específicos. É o caso das luminárias de papelão pendentes sobre a mesa de jantar e bancada da cozinha, e das luminárias de cabeceira utilizadas no dormitório. O sistema de iluminação artificial é todo em LED e dimerizável, buscando uma maior eficiência na relação entre iluminação e consumo. A Figura 3.24 ilustra as luminárias utilizadas no protótipo.

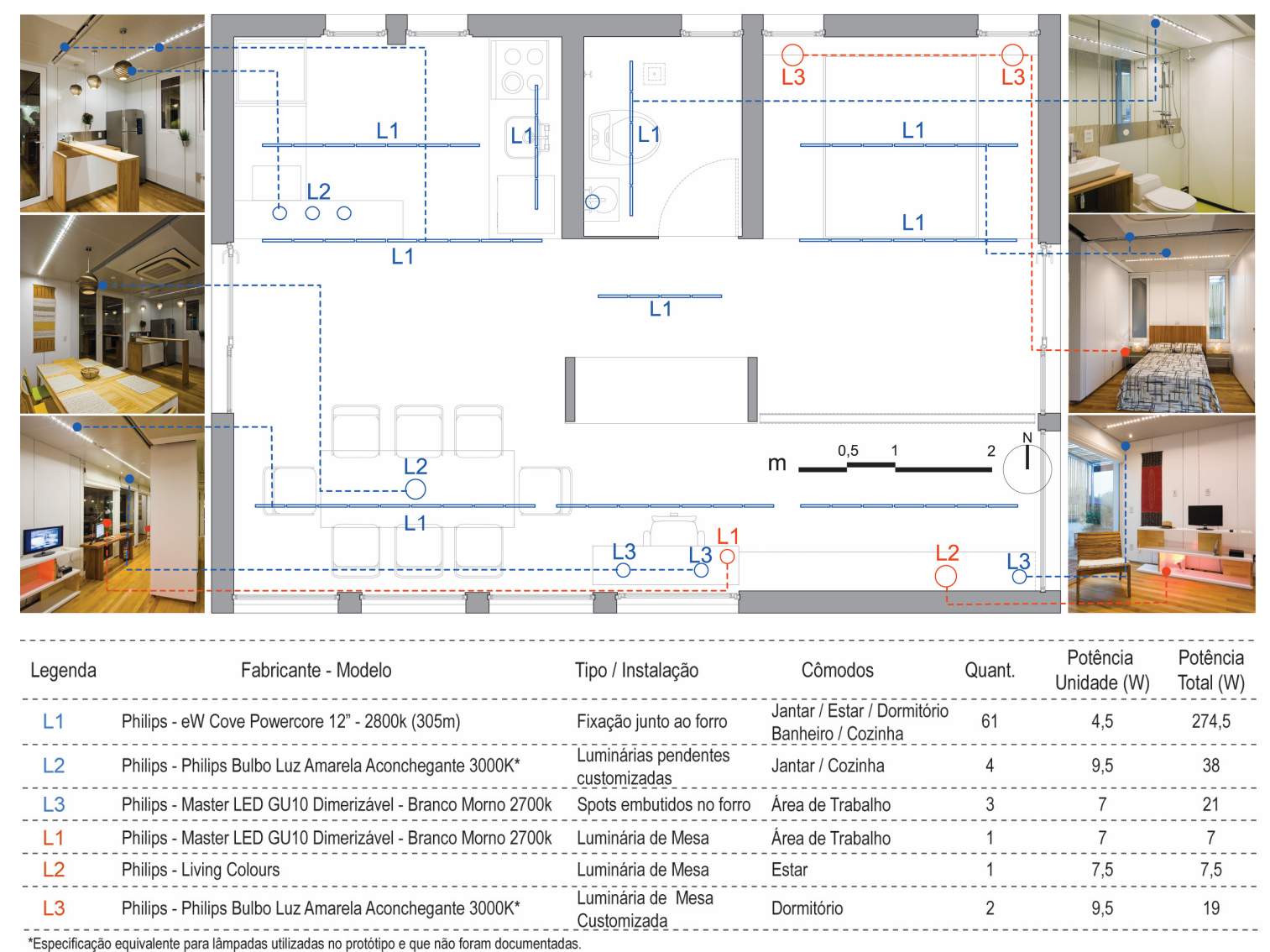

Figura 3.24: Iluminação artificial no protótipo Ekó House.

Fonte: A partir de Projeto Ekó House (2012). Fotografias: @I+D+Art.

Conforme mencionado anteriormente, durante a participação no SDE 2012 foram realizadas medições dos níveis de iluminação no interior do protótipo. Embora as medições não sejam representativas considerando a ocupação anual no protótipo, elas permitem uma visualização qualitativa das condições de iluminação no ambiente interno durante o período da competição, e demonstram que a combinação de iluminação 
natural e artificial atingiu níveis acima de 500 Lux ${ }^{72}$ durante os períodos de medição na bancada de trabalho, garantindo uma boa pontuação na prova de iluminação. Os resultados destas medições podem ser observados no gráfico da Figura 3.25.
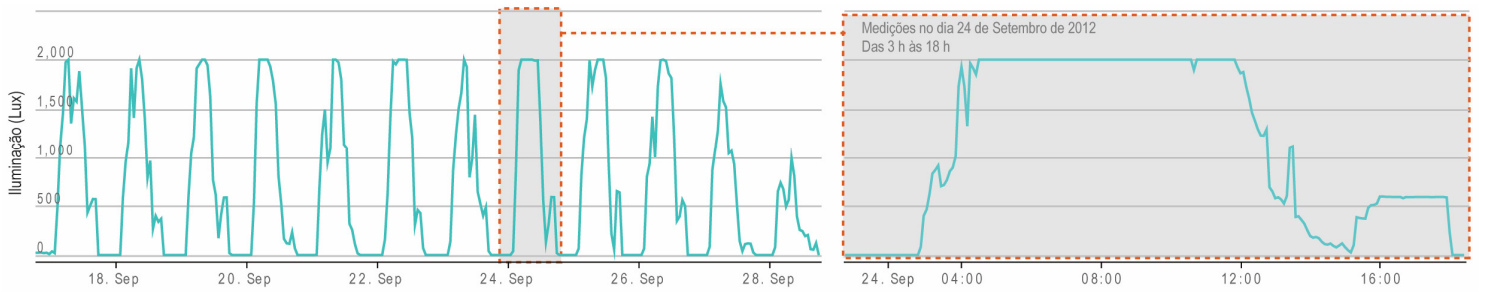

Figura 3.25: Medições de iluminância no protótipo durante sua participação no SDE 2012. Fonte: SDE, 2012.

Os valores de iluminância observados atendem às orientações normativas de níveis de iluminação para áreas de trabalho indicados na Tabela 3.4 durante a maior parte do tempo. A curva de medição ampliada, à esquerda, permite observar que em alguns horários específicos os níveis ficavam abaixo de 500 lux. Estas situações correspondem a períodos em que as medições não contabilizavam pontos e, portanto, as cortinas internas ou persianas externas podiam ser fechadas, o que reduzia os níveis de iluminação no ponto de medição.

\subsection{Sistemas solares}

O estudo da geometria solar não está limitado ao aproveitamento do sol nas estratégias passivas para o condicionamento ambiental, estende-se ao estudo de viabilidade do uso de sistemas solares como os de aquecimento de água e geração de eletricidade. $A$ análise da radiação solar nas diferentes superfícies da envoltória de uma edificação permite tirar máximo proveito destes sistemas. Dias (2014) ilustra, por meio de ábacos, a variação da radiação solar em superfícies com diferentes orientações, em três diferentes regiões do Brasil, divididas por semelhança nos padrões de incidência de radiação solar, conforme demonstra a Figura 3.26. Em edificações novas, atentar a estas variações possibilita que a própria forma da envoltória seja gerada de modo a obter as melhores orientações para o aproveitamento da radiação solar nestes sistemas, otimizando seu rendimento.

\footnotetext{
72 A pontuação máxima, conforme o regulamento do SDE, era obtida para níveis de iluminância acima dos 500 Lux. Em alguns períodos o nível de iluminância atingiu os 2000 Lux. Em uma situação real de ocupação, o excesso de iluminação natural poderia ser controlado por meio das persianas internas ou externas, ajustando estes níveis para o conforto visual dos ocupantes.
} 

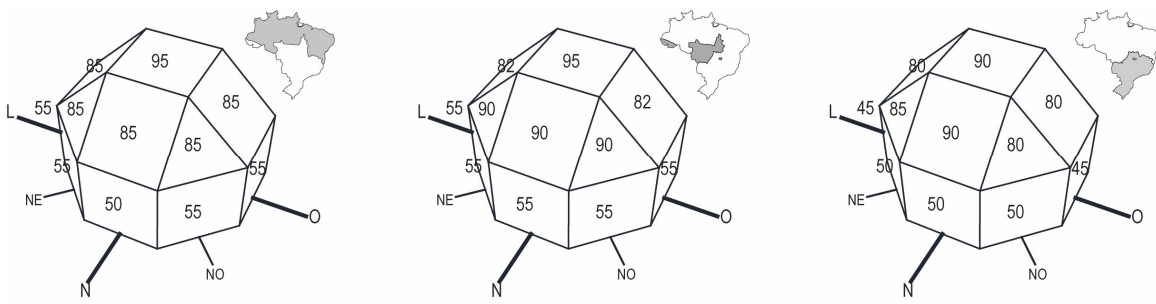

Figura 3.26: Ábacos indicando o percentual de radiação solar recebido por superfícies com diferentes orientações, para três regiões do Brasil.

Fonte: A partir de DIAS, 2014.

Em uma Casa Solar, o programa de necessidades no projeto de arquitetura, previsto na NBR 13.532 (ABNT, 1995), deve contemplar estes sistemas, sua integração à envoltória e também os espaços adequados a todos os seus componentes, considerando sua instalação e manutenção, de modo a atender de forma satisfatória às necessidades dos ocupantes. Para tanto, é fundamental conhecer estes sistemas e as especificidades para que sejam devidamente incorporados ao projeto arquitetônico.

\subsubsection{Sistema de aquecimento solar (SAS)}

Conforme demonstrado no Capítulo 2, o chuveiro elétrico é o equipamento responsável pela maior parcela no consumo de energia elétrica do setor residencial brasileiro. Foi também demonstrado o potencial para exploração da radiação solar como fonte de energia em todo o território nacional. Estes fatores denotam o potencial para aplicação de coletores solares, ou SAS, nos domicílios brasileiros como uma alternativa complementar aos sistemas elétricos ou a gás.

Os coletores solares são sistemas que convertem a luz solar, radiação de onda curta que penetra através dos vidros, em calor, e possibilitando o aproveitamento da radiação solar para o aquecimento de água (COMISSÃO EUROPÉIA, 2004). Os coletores solares consistem em uma cobertura translúcida, uma placa de absorção, e um sistema de transferência de calor, com tubulações de água quente ou ar quente (ROAF et al., 2007).

Os SAS são compostos basicamente por três partes, os coletores solares, o reservatório térmico, e o sistema de circulação da água, que pode ser de circulação natural (termossifão) ou de circulação forçada (bombeado). O SAS pode contar ainda com equipamentos como a bomba hidráulica e o controlador diferencial de temperatura (PROCOBRE, 2009). O SAS deve ser alimentado por um reservatório de água fria. A água aquecida é armazenada no reservatório térmico e servirá para o consumo, alimentado duchas, lavatórios, pias de cozinha, eletrodomésticos, podendo também ser 
utilizada para aquecimento do ambiente através, por exemplo, de radiadores a água. A Figura 3.27 ilustra o SAS com os dois tipos de sistema de circulação.

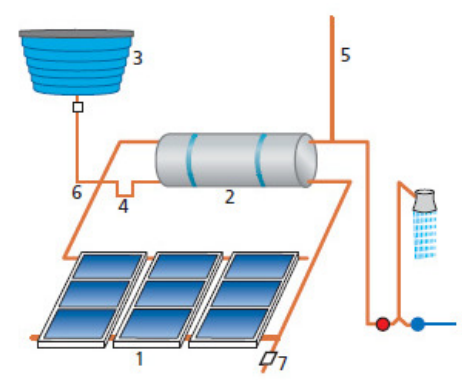

Termossifão ou circulação natural:

1- Coletores solares;

2- Reservatório térmico;

3- Caixa de água fria;

4- Sifao;

5- Respiro;

6- Alimentaçao de água fria com trecho de

tubulaçao resistente a água quente:

7- Dreno.

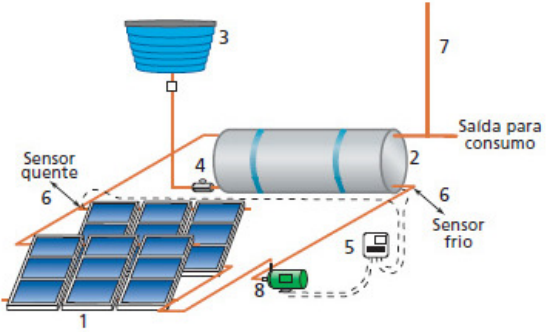

Bombeado ou circulação forçada:

1- Coletores solares;

2- Reservatório térmico:

3- Caixa de água fria;

4- Válvula de retençao;

5- Controlador diferencial de temperatura:

6- Sensores de temperatura;

7- Respiro (ou válvulas de alivio de pressao);

8- Bomba hidráulica.

Figura 3.27: Sistema de aquecimento solar e seus componentes. Fonte: Adaptado de PROCOBRE, 2009.

Os SAS de mais larga aplicação para uso residencial podem ser divididos em três tecnologias, os coletores a vácuo e os coletores planos fechados, e os coletores planos abertos, sendo esta última tecnologia a menos eficiente e cuja aplicação se destina principalmente ao aquecimento de piscinas (IEA, 2012; MIYAZATO, 2012). Todas estas tecnologias utilizam uma folha de metal fino com revestimento escuro, geralmente preto, para maximizar a absorção da energia solar e minimizar as perdas de radiação infravermelha, e usam também a água como um meio de transportar e armazenar o calor coletado. Apesar destas características comuns, estas tecnologias diferem bastante entre si, tanto esteticamente quanto em seu desempenho. O gráfico da Figura 3.28 ilustra a diferença no desempenho de coletores solares.

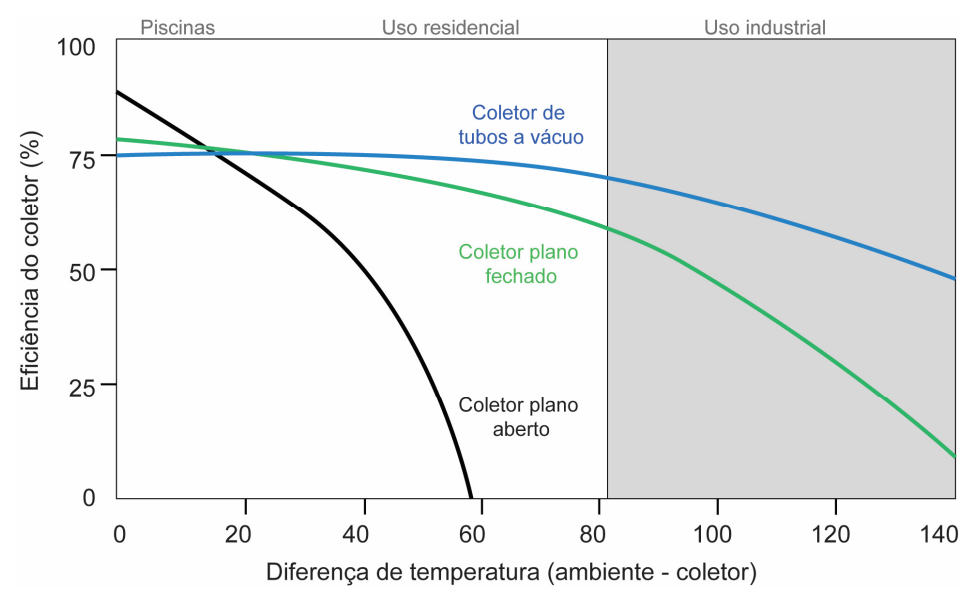

Figura 3.28: Comparação entre diferentes tecnologias de coletores solares e sua eficiência. Fonte: A partir de IEA, 2012. 
Considerando os coletores planos fechados e os coletores a vácuo, é possível elencar vantagens e desvantagens de cada tecnologia, tomando como referência estudos apresentados por Comissão Europeia (2004), IEA (2012), Miyazato (2012), conforme descrito na Tabela 3.6.

\section{Coletor Solar Plano Fechado}

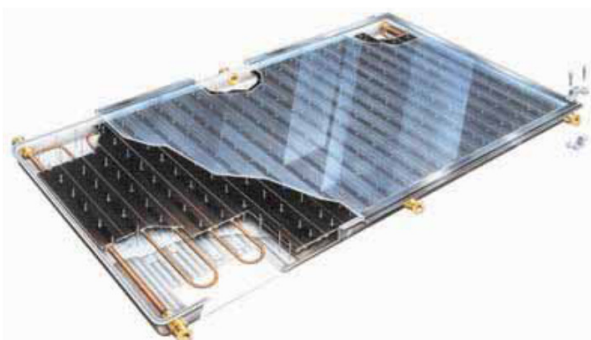

Fonte: Comissão Europeia, 2004 Vantagens

- Custo mais baixo quando comparado aos coletores a vácuo;

- Oferece múltiplas opções de montagem e pode ser facilmente integrado ao telhado e fachadas;

- Apresenta uma boa relação custo-benefício.

\section{Coletor Solar de Tubos a Vácuo}

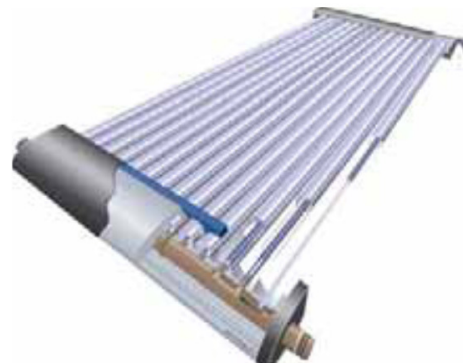

Fonte: Comissão Europeia, 2004

Vantagens

- Maior rendimento em relação ao coletor plano;

- Apresenta boa eficiência com baixa radiação (no inverno, por exemplo);

- Suporta cargas térmicas com maior eficiência do que o coletor plano;

- Mais leve que o coletor plano;

- Menores perdas térmicas;

- Fácil manutenção, pois os tubos podem ser substituídos individualmente;

- Acumulam menos resíduos que os coletores planos.

Desvantagens

Desvantagens

- Menor eficiência em relação aos coletores de tubos a vácuo;

- Necessita de mais área para aquecer uma mesma quantidade de água do que os coletores a vácuo;

- Os vidros e o material absorsor podem acumular

- Custo mais alto do que um coletor plano:

- Maior dificuldade de integração a alguns tipos de telhados e fachadas;

- Não devem ser instalados horizontalmente. resíduos, reduzindo a eficiência do conjunto;

- Não são eficientes em condições de baixa radiação;

- Necessitam mais manutenção.

Tabela 3.6: Vantagens e desvantagens dos coletores solares do tipo plano fechado e a vácuo. Fonte: Elaborado a partir de COMISSÃO EUROPEIA (2004), IEA (2012), MIYAZATO (2012).

A integração de SAS às edificações requer um estudo que considere a disponibilidade de pontos da envoltória onde estes sistemas podem ser instalados, a incidência de radiação sazonal nestas superfícies, o dimensionamento do sistema com base na demanda por água quente, e o espaço necessário para armazenamento da água aquecida (IEA, 2012). Sistemas mais eficientes e uma melhor orientação solar resultam em uma menor área ocupada por coletores para uma mesma quantidade de água aquecida. O projeto arquitetônico pode também favorecer a eficiência destes sistemas aproximando os pontos de coletores, armazenamento e consumo, reduzindo perdas com o transporte da água aquecida. 
Do ponto de vista econômico, Raimo (2007) demonstra que o tempo de retorno do investimento em SAS varia conforme o produto da taxa de cobertura solar ${ }^{73}$ (TCS) e a eficiência do sistema. Sendo assim, este período pode ser de poucos meses, para um sistema eficiente e uma alta TCS, ou chegar a cerca de 8 anos quando o sistema apresenta baixa eficiência e a TCS é menos favorável. A vida útil destes sistemas é de cerca de 20 anos (COMISSÃO EUROPEIA, 2004; ROAF et al., 2007)

Outra vantagem dos SAS é que a instalação não depende de legislações especificas pois estes sistemas não são interligados a redes ou infraestruturas públicas, como é o caso dos sistemas fotovoltaicos (COMISSÃO EUROPEIA, 2004). Por outro lado, o dimensionamento do sistema tem que estar de acordo com a demanda e também com o espaço disponível para armazenar o volume de água aquecido. "O super ou sub dimensionamento de um sistema de aquecimento solar pode transformar-se em um investimento inútil, não rentável e até mesmo dispendioso" (BORGES, 2000, p. 1).

Considerando o dimensionamento dos SAS, é importante abordar o conceito de Fração Solar (FS), que é definido pelo percentual da demanda total por agua quente que é suprida pelo sistema solar (BROWN, DEKAY, 2004; IEA, 2012; ROAF et al., 2007). Do ponto de vista ambiental, o uso destes sistemas apresenta vantagens na redução de emissões de GEE quando comparado, por exemplo, a sistemas elétricos ou a gás. As emissões evitadas podem ser mensuradas com base na fração solar que terá um SAS, comparando a energia que deixa de ser consumida a partir de fontes não renováveis, como o GLP, ou mesmo a eletricidade disponibilizada na rede.

\subsubsection{Sistema fotovoltaico}

Outra forma de se aproveitar a radiação solar que incide diariamente sobre a superfície da terra é a geração direta de eletricidade, através do efeito fotovoltaico ${ }^{74}$. Graças a este efeito, as células fotovoltaicas são uma usina independente capaz de converter a energia solar diretamente em energia elétrica. Diversas células são interconectadas para gerar um módulo fotovoltaico, que podem ser associados em série ou em paralelo configurando uma maior unidade de potência, e esta associação pode ser integrada às edificações. Estas diferentes escalas são exemplificadas na Figura 3.29.

\footnotetext{
73 Taxa de Cobertura Solar (TCS) é definida como a razão entre a energia final evitada (pelo SAS) e a energia final necessária para a satisfação do consumidor (RAIMO, 2007). Neste trabalho, adota-se o conceito de Fração Solar, que é equivalente ao de TCS.

74 Efeito característico de materiais semicondutores, como o silício (si), que, quando exposto à radiação solar, são capazes de gerar corrente elétrica (IPCC, 2012; RÜTHER, 2004).
} 


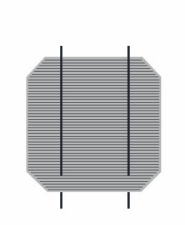

Célula Fotovoltaica

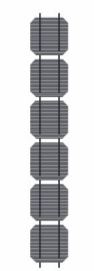

Células

Conectadas

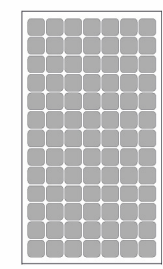

Módulo

Fotovoltaico

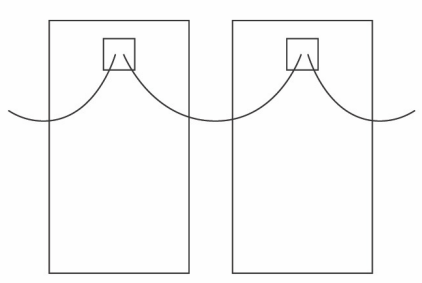

Módulos

Conectados

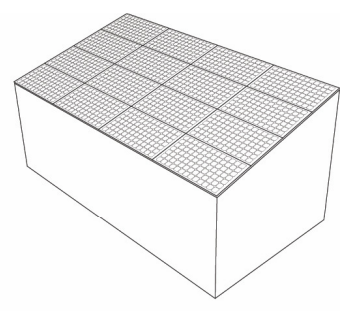

Sistema de Geração Fotovoltaica

Figura 3.29: Princípio modular dos fotovoltaicos, partindo da célula como unidade básica, para os diferentes arranjos possíveis.

Fonte: Elaborado a partir de WELLER et al., 2010.

Os SFV podem ser instalados isoladamente ou conectados à rede de distribuição. No caso deste estudo, o enfoque é no uso de SFV conectados à rede elétrica, ou seja, ao SIN, no caso do Brasil. Através de um sistema de compensação, que já é viável no país conforme descrito no Capítulo 2, uma edificação conectada à rede pode gerar energia por meio de um SFV. A energia excedente gerada é injetada na rede e, quando necessário, a edificação utiliza energia fornecida pela rede elétrica. Os SFV conectados à rede elétrica dispensam o uso de baterias, pois exportam a energia excedente à rede, que serve como um sistema virtual de armazenamento (IEA, 2012).

Neste caso, o SFV é composto por módulos fotovoltaicos, inversores que convertem a corrente contínua em corrente alternada, componentes e cabeamento elétricos, proteções contra sobretensão e descargas atmosféricas, e caixas elétricas (IEA, 2012; RÜTHER, 2004). Um medidor de energia geralmente é instalado para visualizar e controlar o desempenho do sistema, e a conexão à rede também requer um medidor para contabilizar a energia que é injetada na rede (IEA, 2012).

É necessário prever também o sistema de fixação dos módulos fotovoltaicos à envoltória da edificação, observando quesitos como adequação formal e estética, e o acesso para limpeza e manutenção do sistema. A Figura 3.30 demonstra esquematicamente os componentes e funcionamento de um sistema fotovoltaico conectado à rede. 


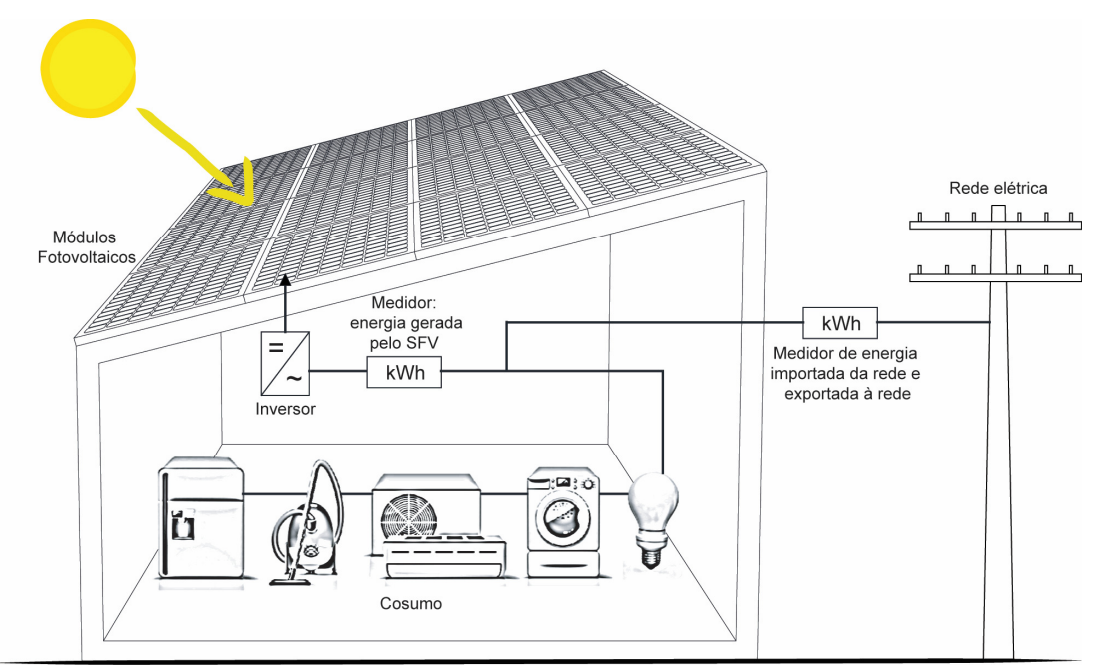

Figura 3.30: Sistema fotovoltaico conectado à rede.

Fonte: Adaptado de SUPSI, 2014a; RÜTHER, 2004.

Existem diferentes tipos de células fotovoltaicas, que utilizam diferentes tecnologias e variam em sua aparência, possibilidades de aplicação e eficiência. A eficiência é mensurada em um valor percentual que expressa a quantidade de energia solar que atinge o módulo fotovoltaico e é transformada em energia elétrica. As células de silício monocristalino são as mais eficientes dentre as disponíveis no mercado, seguidas das de silício policristalino (IEA, 2012). As tecnologias de filme fino utilizam diferentes materiais, como silício amorfo, telureto de cádmio (CdTe) e disseleneto de cobre (gálio) e índio (CIS e CIGS) (RÜTHER, 2004), e são menos eficientes que as de silício. A Tabela 3.7 relaciona algumas das tecnologias fotovoltaicas e sua eficiência.

\begin{tabular}{lccc}
\hline \multicolumn{1}{c}{ Tipo de Célula } & $\begin{array}{c}\text { Eficiência do } \\
\text { Módulo (\%) }\end{array}$ & $\begin{array}{c}\text { Produção por área de } \\
\text { módulos }\left(\mathbf{W}_{\mathbf{p}} / \mathbf{m}^{\mathbf{2}}\right)\end{array}$ & $\begin{array}{c}\text { Área necessária para } \\
\mathbf{1} \mathbf{~ k W}_{\mathbf{p}}\left(\mathbf{m}^{\mathbf{2}}\right)\end{array}$ \\
\hline Silício Monocristalino & 12 a 20 & 120 a 200 & 9 a 5 \\
\hline Silício Policristalino & 11,5 a 15 & 115 a 150 & 7 a 9 \\
\hline Silício Amorfo & 5 a 9 & 50 a 90 & 11 a 21 \\
\hline CIS & 8 a 11 & 80 a 110 & 9 a 13 \\
\hline CdTe & 6 a 11 & 60 a 110 & 9 a 17 \\
\hline
\end{tabular}

Tabela 3.7: Eficiência média de diferentes tecnologias de células fotovoltaicas.

Fonte: A partir de WELLER et al., 2010.

A integração dos módulos fotovoltaicos na arquitetura pode se dar de diferentes formas. Pesquisas voltada à integração de fotovoltaicos a edificações (ou Building Integrated Photovoltaics - BIPV) vem contribuindo para a evolução e diversificação dos módulos fotovoltaicos disponibilizados no mercado, de modo a facilitar esta integração, tanto em novas edificações como em edificações existentes. Segundo Scognamiglio, Røstvik (2012) e IEA (2012), esta integração pode ocorrer, conceitualmente, de seis maneiras distintas, conforme demonstrado na Figura 3.31. 


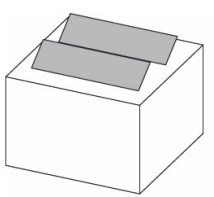

Elemento técnico aplicado à envoltória

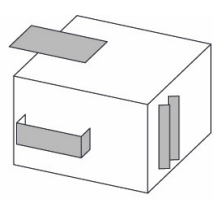

Elemento técnico com dupla função

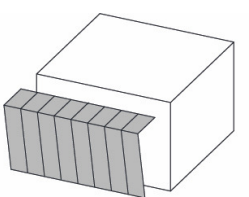

Estrutura independente

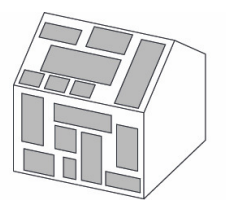

Composição de fachadas e coberturas

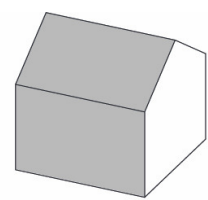

Superfícies de fachadas e coberturas

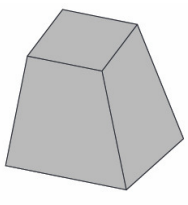

Outros além das tipologias anteriores

Figura 3.31: Tipologias de integração de SFV a edificações.

Fonte: A partir de IEA, 2012; Scognamiglio, Røstvik, 2012.

Os módulos fotovoltaicos podem cumprir funções além da geração de energia elétrica. As diferentes tecnologias de células fotovoltaicas também permitem uma diversificação em sua aplicação, podendo ser integradas a vidros em janelas e claraboias, parapeitos, elementos de cobertura ou fachada. A integração do sistema fotovoltaico a componentes construtivos da edificação contribui na redução do custo final destes sistemas, uma vez que ele passa a ser integrado a estes componentes, ao invés de se sobrepor a eles, reduzindo custos com a estrutura dos módulos para suportar as células fotovoltaicas (IEA, 2012). A Figura 3.32 ilustra algumas destas possibilidades.

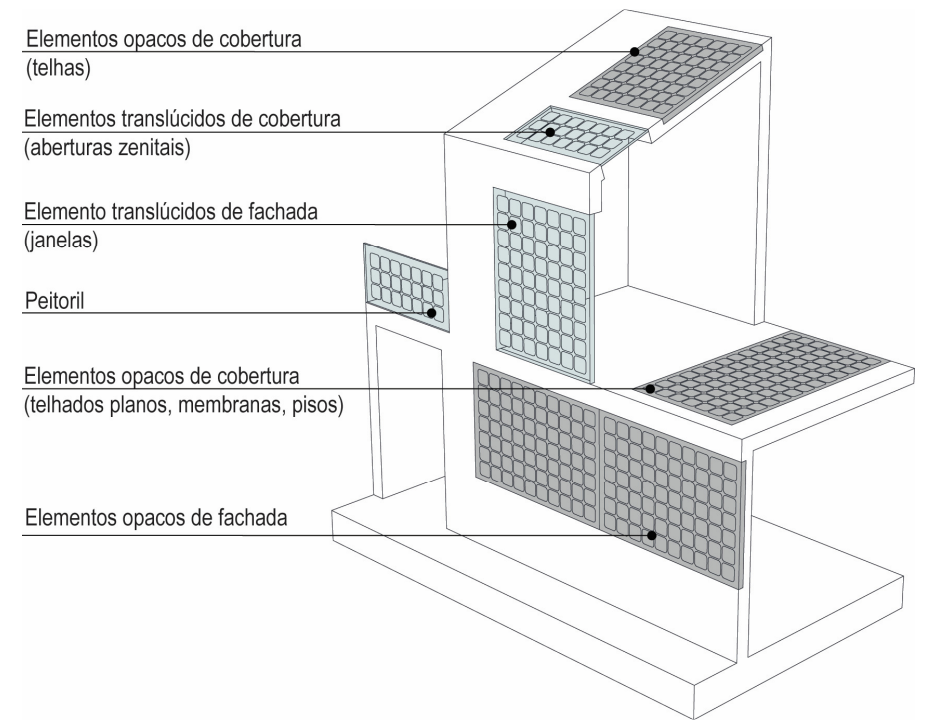

Figura 3.32: Integração de módulos fotovoltaicos a componentes da edificação. Fonte: Adaptado de SUPSI, 2014b.

Do ponto de vista ambiental, os SFV são uma fonte limpa e renovável de energia, não emitindo gases como $\mathrm{CO}_{2}, \mathrm{NO}_{\mathrm{x}}$ e $\mathrm{SO}_{2}$ para gerar eletricidade, e os módulos de silício não são produtos tóxicos, mesmo na etapa de manufatura (ROAF et al., 2007). A vida útil de tecnologias consolidadas de SFV é de 30 anos, sendo que a garantia da potência típica nominal do módulo é da ordem de $80 \%$ após 25 anos de uso; já os inversores apresentam uma vida útil de cerca de 15 anos (FTHENAKIS, 2011). Há cerca de 10 anos, estudos indicavam um tempo de retorno de energia variando entre 2 e 5 anos 
para os SFV (DOE, 2004). Mais recentemente, estudo realizado com base em SFV disponíveis no mercado aponta que este tempo é de menos de 2 anos para as principais tecnologias comercializadas (WILD-SCHOLTEN, 2013). A Tabela 3.8 resume dados referentes ao tempo de retorno de energia (energy payback time) de SFV e as emissões de GEE específicos por tecnologia, em condições de irradiação de $1700 \mathrm{kWh} / \mathrm{m}^{2}$ ao ano.

\begin{tabular}{lccccc}
\hline & $\begin{array}{c}\text { Silício } \\
\text { Monocristalino }\end{array}$ & $\begin{array}{c}\text { Silício } \\
\text { Policristalino }\end{array}$ & $\begin{array}{c}\text { Silício } \\
\text { Amorfo }\end{array}$ & CdTe & CIGS \\
\hline $\begin{array}{l}\text { Tempo de retorno de } \\
\text { energia (anos) }\end{array}$ & 1,96 & 1,24 & 1,39 & 0,68 & 1,02 \\
\hline $\begin{array}{l}\text { Emissões de GEE } \\
\left(\mathrm{CO}_{2} \text {-eq/kWh) }\right.\end{array}$ & 38,1 & 27,8 & 34,8 & 15,8 & 21,4 \\
\hline
\end{tabular}

Tabela 3.8: Tempo de retorno de energia e emissões de GEE para distintas tecnologias fotovoltaicas. Fonte: A partir de WILD-SCHOLTEN, 2013.

Rüther (2004) e Roaf et al. (2007) apontam algumas vantagens da geração fotovoltaica distribuída em edificações urbanas, como a redução de perdas nas etapas de transmissão e distribuição; a possibilidade de utilizar as próprias superfícies da envoltória para geração, sem necessitar ocupar áreas adicionais para o SFV; possibilidade de oferecer elevado fator de capacidade a alimentadores da rede com picos diurnos de consumo; e modularidade e facilidade na instalação, podendo adicionar capacidade de geração rapidamente à rede de distribuição. A ausência de ruídos, confiabilidade, baixa manutenção e a possibilidade de movimentar ou transferir o sistema de um edifício a outro, se necessário, são outros aspectos positivos atribuídos aos módulos fotovoltaicos (ROAF et al., 2007).

\subsubsection{Sistemas solares no protótipo Ekó House}

Desde sua concepção inicial, o projeto para o protótipo Ekó House focou em um aproveitamento otimizado de sistemas solares, tanto para aquecimento de água quanto para geração de energia elétrica. A Ekó House foi projetada para ser utilizada como uma unidade de hospedagem em áreas ambientalmente sensíveis do Brasil, devido ao seu baixo impacto ambiental ${ }^{75}$. Sendo assim, esta estratégia responde ao objetivo de obter um bom desempenho nas provas especificas para os sistemas solares, e também de contribuir para prover energia a comunidades que habitam áreas isoladas $\mathrm{e}$

\footnotetext{
75 As equipes participantes do SDE 2012 tinham de definir um público alvo para o qual seus protótipos seriam desenvolvidos. A equipe brasileira optou por desenvolver um protótipo que configurasse uma unidade de hospedagem de baixo impacto ambiental, para implantação em áreas isoladas e ambientalmente sensíveis do país. Esta estratégia visava que um maior número de pessoas pudesse conhecer e vivenciar o protótipo, e com isso aprender sobre um modo de vida mais sustentável, e incorporar esse aprendizado ao seu cotidiano (PROJETO EKÓ HOUSE, 2012).
} 
ambientalmente sensíveis do país (PROJETO EKÓ HOUSE, 2012; ANTONIO et al., 2014).

Desta forma, toda a área de cobertura, que é a superfície do protótipo que recebe maior incidência de radiação solar ao longo do ano, foi destinada à instalação dos sistemas solares. Foi desenvolvida uma estrutura de alumínio, acoplada sobre a cobertura de telhas zipadas, e que suporta os sistemas fotovoltaicos e coletores solares para aquecimento de água. Esta estrutura pode ser regulada em diferentes ângulos $\left(10^{\circ}, 15^{\circ}\right.$, $20^{\circ}, 25^{\circ}$ e $30^{\circ}$ ). Desta forma, a cobertura pode ser ajustada ao longo do ano em relação ao sol, para uma maior eficiência dos sistemas. Considerando também o retorno do protótipo ao Brasil após o SDE 2012, esta facilidade no ajuste da inclinação garante a eficiência do sistema para uma aplicação do protótipo em diferentes regiões do país. A Figura 3.33 ilustra o sistema de cobertura projetado para a instalação dos sistemas solares na Ekó House.
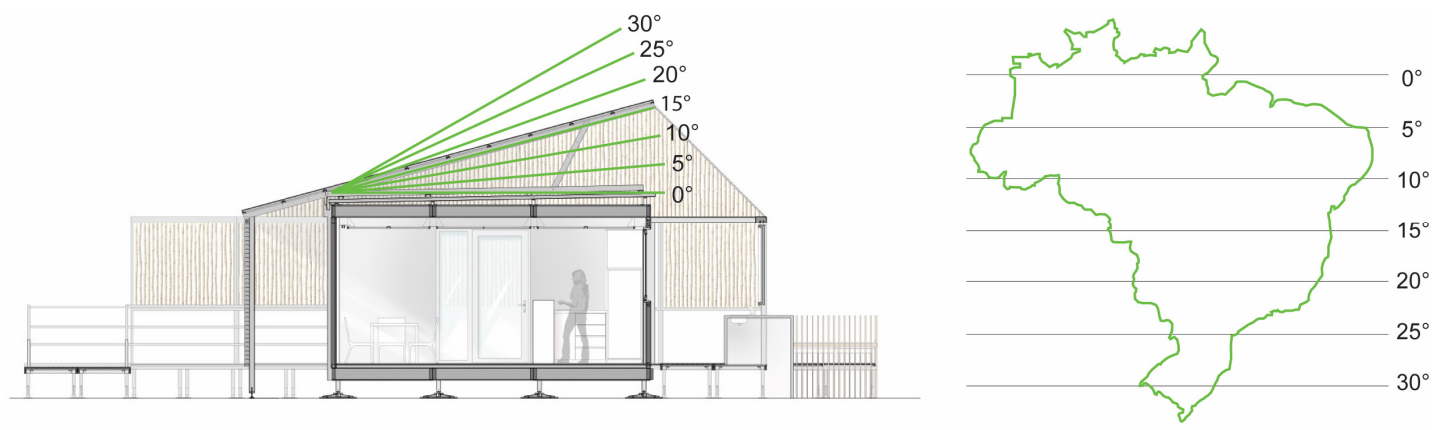

Figura 3.33: Estrutura ajustável para os sistemas solares no protótipo Ekó House. Fonte: A partir de DIAS, 2014; PROJETO EKÓ HOUSE, 2012.

\subsubsection{Sistema solar para aquecimento de água}

No protótipo Ekó House, a demanda por agua quente é associada a banhos, lavatório do banheiro, pia da cozinha, máquina de lavar louças, máquina de lavar roupas, e também para alimentar os radiadores à água para aquecimento do ambiente interno nos períodos de frio. Para suprir esta demanda, o protótipo conta com quatro coletores solares de tubos evacuados (u-pipe). Estes coletores totalizam uma área de 5,44m². 0 reservatório térmico para armazenamento da água aquecida tem capacidade para 300 litros. A Figura 3.34 demonstra este sistema no protótipo Ekó House. 


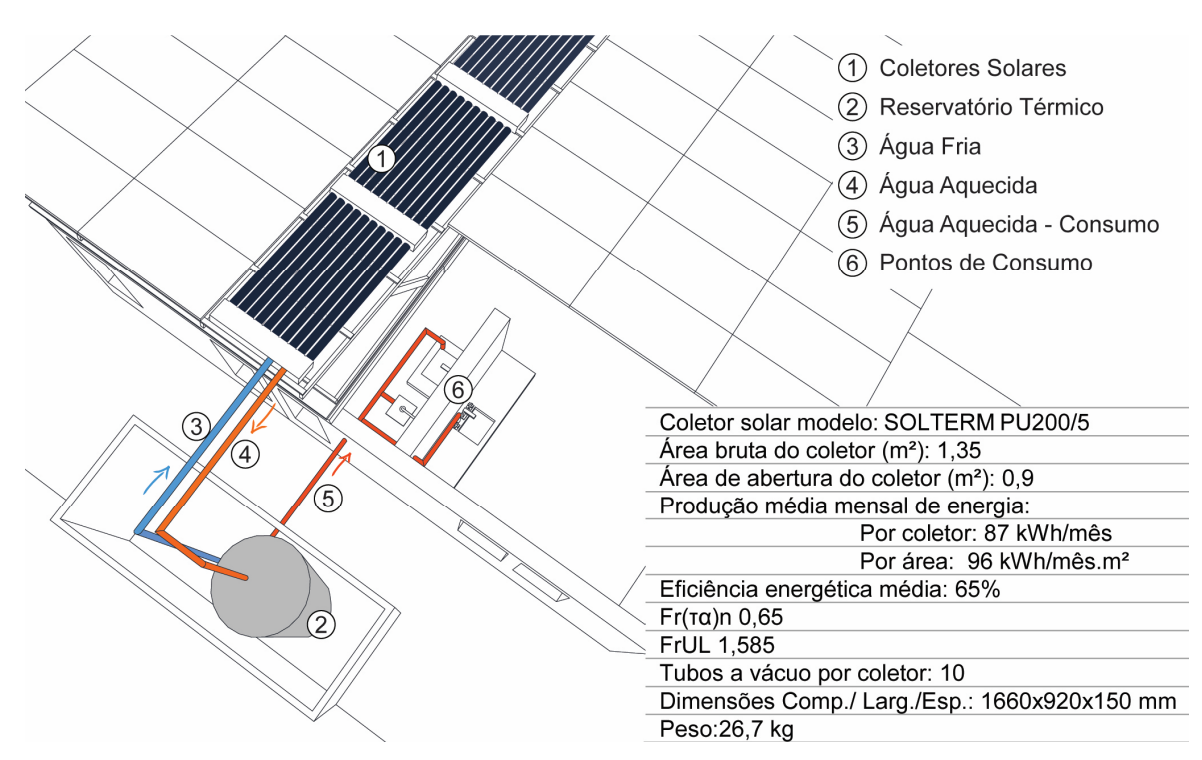

Figura 3.34: Diagrama do SAS do protótipo Ekó House e características técnicas dos coletores solares. Fonte: Elaborado a partir de PROJETO EKÓ HOUSE, 2012; SOLTERM, 2015.76

Para aumentar a eficiência do sistema e evitar perdas, os coletores solares e o reservatório térmico estão alinhados e próximos aos pontos de uso no banheiro e cozinha. Este posicionamento evita perdas térmicas, pois reduz as distâncias de circulação da água quente (PROJETO EKÓ HOUSE, 2012).

O projeto para o SAS do protótipo Ekó House não foi completamente documentado, portanto, foram realizados cálculos considerando as especificações técnicas dos coletores solares adotados e os dados climáticos da cidade de Madri. A demanda adotada para os cálculos foi de 200 litros $/ \mathrm{dia}^{77}$, a uma temperatura de $50^{\circ} \mathrm{C}$. Os cálculos foram feitos considerando o uso do reservatório térmico presente no protótipo, com capacidade de 300 litros, e também sem este reservatório, a fim de verificar o potencial máximo de produção do SAS. A inclinação adotada foi de $30^{\circ}$, a mais favorável ao longo do ano para a latitude de Madri.

Quando os cálculos são feitos sem considerar armazenamento da água aquecida, considera-se que o consumo acontece de imediato. Quando se armazena a água aquecida, o sistema perde em eficiência como um todo. No caso específico do protótipo Ekó House, estas perdas são agravadas devido ao fato de que o próprio reservatório não possui capacidade de armazenamento para todo o volume de água que os coletores

\footnotetext{
76 Os dados técnicos dos coletores foram fornecidos pela empresa SOLTERM, via correio eletrônico, por solicitação da autora.

77 Devido à ausência de documentação referente ao cálculo da demanda de água quente para o protótipo, optou-se por definir um volume de 100 litros por ocupante, totalizando 200 litros/dia. Trata-se de um volume alto, visto que o volume mínimo indicado por habitante é de 50 litros/dia (INMETRO, 2012). No entanto, o protótipo conta com equipamentos que utilizam água quente e também com o sistema de radiadores à água para aquecimento.
} 
têm capacidade de aquecer. A FS obtida em ambas as situações gera produção excedente ao longo do ano. Os resultados destes cálculos são apresentados no gráfico da Figura 3.35.

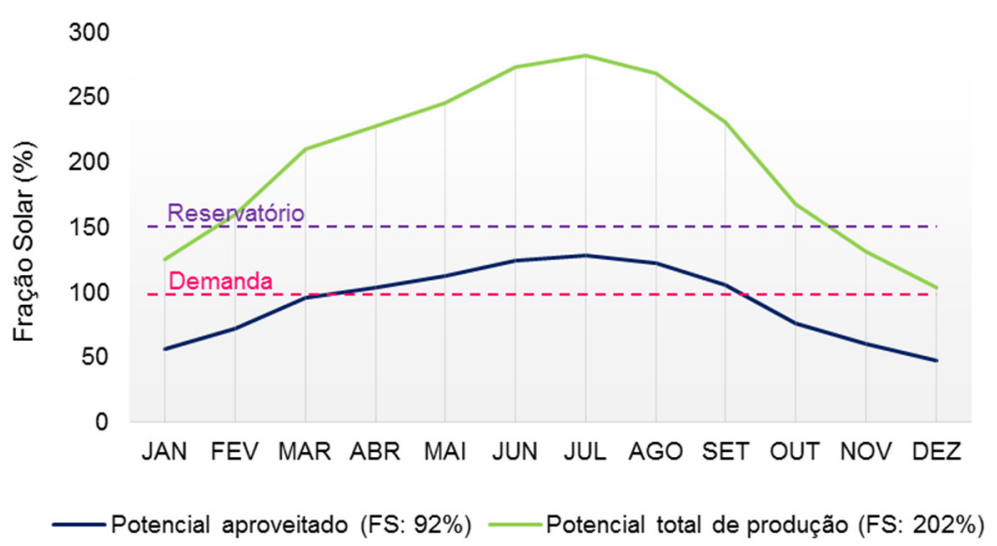

Figura 3.35: Desempenho do SAS instalado no protótipo Ekó House, considerando o sistema com e sem reservatório para o armazenamento da água aquecida.

Fonte: Cálculos realizados no RETScreen®.

A produção excedente remete aos aspectos observados no item 3.7.1, no que se refere a equilibrar a FS do sistema com o volume a ser armazenado, e também com a demanda, visto que, geralmente, a produção excedente não pode ser compartilhada com outras edificações. Nos SAS, a forma mais eficiente de aproveitamento de energia é gerá-la o mais próximo possível ao momento do uso. Acumular água quente por longos períodos não é eficiente e gera a necessidade de controlar a qualidade da água quente, evitando a proliferação da bactéria legionela, um dos riscos mais críticos para o armazenamento de água quente para o uso/consumo humano.

O protótipo Ekó House foi desenvolvido visando sua aplicação em locais remotos e, teoricamente, o volume excedente de água aquecida pelo SAS do protótipo poderia ser utilizado suprir a demanda de unidades habitacionais locais (PROJETO EKÓ HOUSE, 2012). No entanto, considerando os aspectos mencionados, bem como a necessidade em se ampliar a capacidade de armazenamento para atender ao volume de água aquecido pelo sistema, entende-se que uma solução mais racional seria distribuir os coletores entre as unidades consumidoras, aproximando geração e consumo e evitando a necessidade de uma maior área para reservatórios junto ao protótipo. Durante o SDE 2012, apenas dois dos coletores do protótipo foram conectados ao SAS, para que o volume de água aquecido fosse compatível com a capacidade do reservatório e com a demanda para o funcionamento da casa durante o concurso. 


\subsubsection{Sistema solar fotovoltaico (SFV)}

Visando obter um maior rendimento do SFV, optou-se pelo uso de módulos com células de silício monocristalino, dispostos na cobertura do protótipo Ekó House, superfície que recebe maiores níveis de radiação solar ao longo do ano, conforme demonstrado no item 3.4.1. A Tabela 3.9 ilustra as características técnicas dos módulos fotovoltaicos escolhidos para o protótipo.

\begin{tabular}{ll}
\hline \multicolumn{2}{c}{ Sunpower 230 Solar Panel } \\
\hline Potência Pico (+/- 5\%) & $230 \mathrm{~W}$ \\
\hline Potência Pico por áre a & $185 \mathrm{~W} / \mathrm{m}^{2}$ \\
\hline Eficiência & $15,8 \%$ \\
\hline Células Fotovoltaicas & 72 células monocristalinas \\
\hline Estrutura & Alumínio anodizado \\
\hline Fechamento frontal & Vidro temperado $3,2 \mathrm{~mm}$ \\
\hline Peso & $15 \mathrm{~kg}$ \\
\hline
\end{tabular}

Tabela 3.9: Características técnicas e de desempenho do modelo de painel fotovoltaico adotado para o protótipo Ekó House.

Fonte: PROJETO EKÓ HOUSE, 2012.

O protótipo conta com 48 painéis fotovoltaicos, com uma eficiência de $18,5 \%$, resultando em uma potência total instalada de $11,04 \mathrm{kWp}$. São utilizados dois inversores com capacidade de $10 \mathrm{~kW}$, sendo que a capacidade máxima dos inversores é $5 \%$ mais alta que a dos módulos fotovoltaicos, assegurando uma relação ótima entre módulos e inversores (PROJETO EKÓ HOUSE, 2012).

Conforme mencionado inicialmente, a cobertura é orientada a Sul (Hemisfério Norte), e sua inclinação pode variar de $0^{\circ}$ a $30^{\circ}$. O gráfico da Figura 3.36 demonstra a geração estimada para o sistema fotovoltaico adotado para o protótipo, considerando sua localização em Madri. Os cálculos foram realizados para diferentes ângulos de inclinação da cobertura, e também considerando o uso de um sistema de rastreamento do sol.

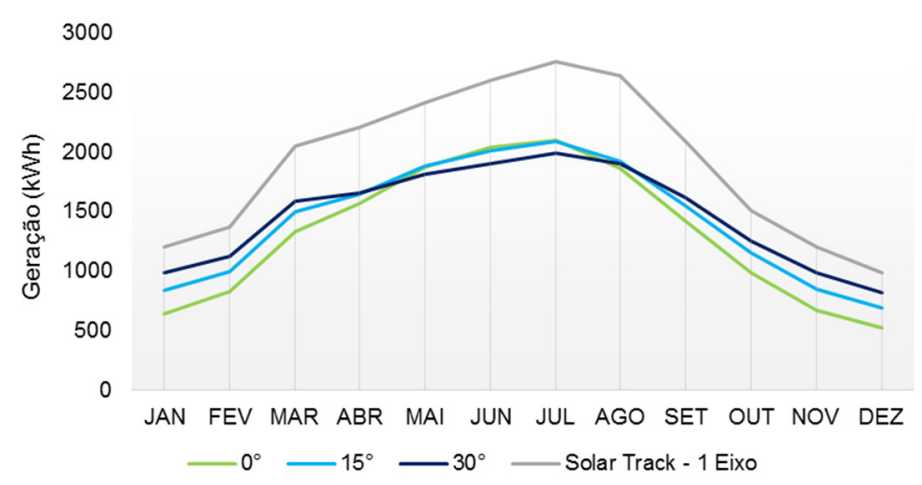

Figura 3.36: Geração de energia elétrica para o sistema fotovoltaico da Ekó House em Madri, em diferentes ângulos de inclinação.

Fonte: Cálculos realizados no RETScreen®. 
A geração fotovoltaica excede a demanda por consumo do protótipo, conforme será demonstrado no item 3.8.1. No entanto, conforme descrito no item 3.7.2, a energia excedente destes sistemas pode ser armazenada por mais tempo em um banco de baterias, ou virtualmente na rede. A proposta do protótipo Ekó House é de utilizar a energia excedente para alimentar moradias, escolas, postos de saúde, e outros equipamentos em comunidades isoladas (PROJETO EKÓ HOUSE, 2012; ANTONIO et al., 2014).

\subsection{Consumo de energia em uma casa solar}

A energia elétrica consumida nas edificações está associada ao uso de eletrodomésticos e equipamentos, e estes geralmente são o foco quando se trata de reduzir o consumo de energia. No entanto, o consumo destes equipamentos depende não apenas de sua eficiência, mas também da interação com a envoltória das edificações e com os ocupantes (PROCEL, 2011). Dentre os equipamentos utilizados em uma residência, os que têm sua demanda e, portanto, seu consumo mais associado às características físicas da edificação são aqueles utilizados para o condicionamento ambiental, ou seja, sistemas de iluminação artificial e condicionamento de ar.

Conforme demonstrado nos itens 3.5 e 3.6, estratégias bioclimáticas e de aproveitamento de iluminação natural podem contribuir no desempenho da edificação, provendo conforto ambiental aos ocupantes e reduzindo o consumo de eletricidade com sistemas de iluminação artificial e condicionamento de ar.

No Capítulo 1 foi apontado que a dissociação entre as etapas de geração e consumo no ciclo do uso da energia contribui para a ineficiência energética, e as EEZ foram apontadas como uma forma de reestabelecer esta ligação, por promover uma maior conscientização dos ocupantes sobre a produção e consumo de energia. Neste sentido, os sistemas de automação residencial são uma importante ferramenta para integrar e monitorar os diferentes sistemas atuantes em uma Casa Solar, e informar os ocupantes quanto à geração e consumo de energia. $\mathrm{O}$ armazenamento dos dados de operação e desempenho de uma casa permite mapear tendências que podem ser analisadas para buscar soluções visando aumentar a eficiência no consumo de energia para a manutenção do conforto ambiental (GALLOWAY, 2004).

A automação residencial vem ganhando espaço no mercado como forma de aumentar não só a eficiência na operação de edificações, mas também o conforto, comodidade e 
segurança dos ocupantes. O sistema de automação integra diversos componentes, estruturados em um esqueleto de controle que fornece dados refinados de medições provenientes de sensores que detectam consumo de equipamentos, eletrodomésticos, eletrônicos, sistemas de iluminação, sistemas de geração de energia, condições de temperatura, umidade, luminosidade, dados meteorológicos, presença de pessoas, entre outros. Estes, por sua vez são registrados e podem ser gerenciados, ou controlados, pelos usuários por meio de interfaces interativas, como computadores, telefones celulares e similares. O diagrama da Figura 3.37 ilustra a estrutura de um sistema de automação residencial.

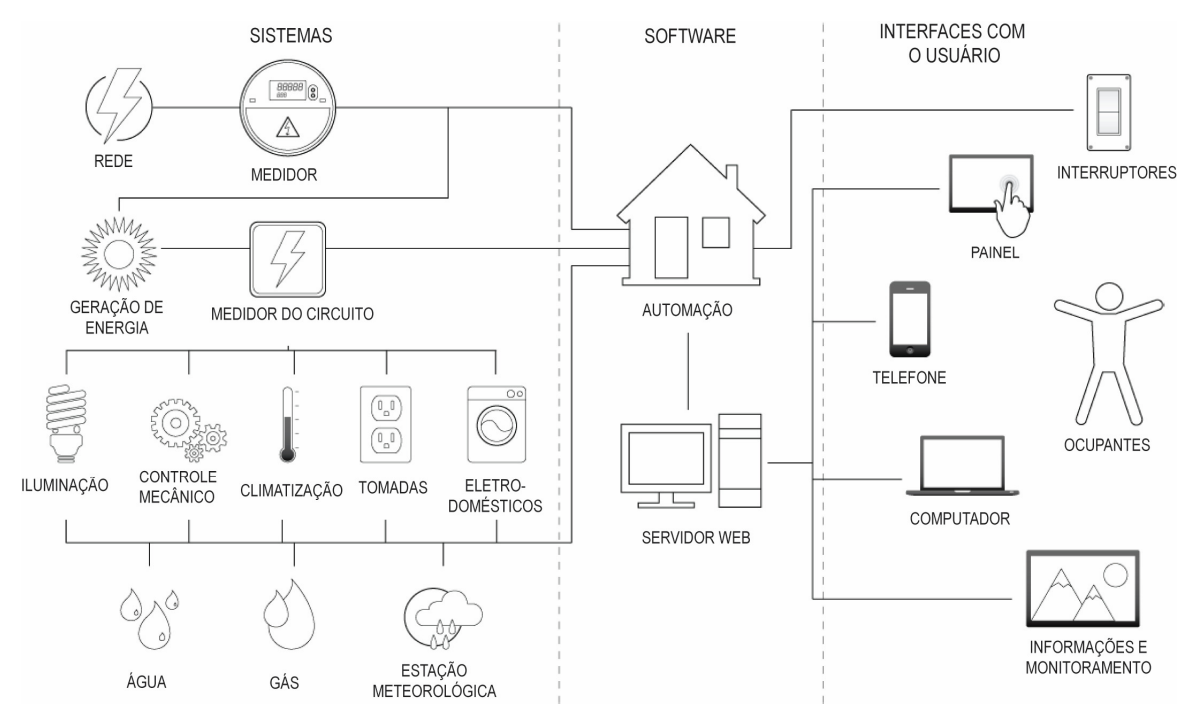

Figura 3.37: Estrutura de um sistema de automação residencial.

Fonte: Adaptado de BARTRAM, WOODBURI, 2011.

Estudos vêm demonstrando as possibilidades de se evitar desperdício no consumo de energia, ou outros recursos naturais como a água, por meio dos sistemas de automação residencial, que podem ser programados para acionar ou desligar equipamentos com base na presença de pessoas, na definição de níveis de temperatura e iluminação desejados, contribuindo para evitar desperdício de energia (BARTRAM, L., WOODBURY, 2011; MEYERS, R. J, 2010; WOOD, G., NEWBOROUGH, M., 2007). No entanto, muita atenção tem sido dada ao papel do usuário na conservação de energia em edificações. Neste sentido, as interfaces interativas destes sistemas devem ser desenvolvidas no sentido de facilitar interação do usuário (BECKER et al., 2011).

Bartram, Woodbury (2011) apontam que o ponto desafiador do projeto de automação é equilibrar a responsabilidade de solicitar ações por parte do usuário e ainda auxiliá-lo na realização dessas ações. Além disso, demonstrar o custo de se desperdiçar energia pode causar um grande impacto e resultar em uma mudança de hábitos por parte dos 
ocupantes para reduzir o consumo de energia. A possibilidade de visualizar históricos de dados de despesas em períodos mensais ou anuais tende a exercer uma maior influência e impacto sobre o usuário, o que também pode influenciar positivamente na busca por uma maior conservação de energia (WOOD, NEWBOROUGH, 2007). Estes sistemas e suas interfaces apresentam grande potencial para ampliar as possibilidades de projeto em residências que visam à eficiência energética e que possam instigar as pessoas a utilizar os recursos naturais de modo mais racional.

\subsubsection{Balanço Energético no protótipo Ekó House}

Para determinar o consumo de energia elétrica do protótipo Ekó House durante um ano de operação, foram realizadas simulações com a ferramenta computacional Energy Plus 7.178. Para tanto, foram verificados os consumos específicos de todos os equipamentos e sistemas a serem utilizados ${ }^{79}$ e alimentados por energia elétrica. Foi também definido um calendário de ocupação, assumindo que o protótipo é projetado para ser ocupado por duas pessoas (PROJETO EKÓ HOUSE, 2012). A partir destes dados, foram estimados os tempos de uso para cada um dos equipamentos e sistemas, com base no calendário de ocupação e na manutenção do conforto ambiental, de acordo com parâmetros definidos pelo SDE 2012. Foram também contabilizadas as cargas térmicas internas, incluindo a atividade metabólica dos ocupantes. A participação no consumo por uso final é indicada no gráfico da Figura 3.38.

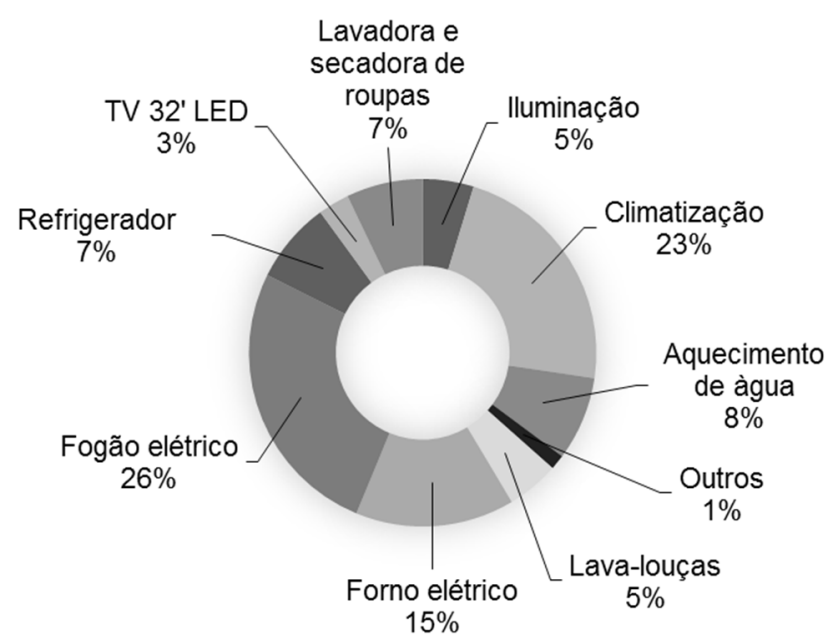

Figura 3.38: Participação no consumo por equipamentos e sistemas no protótipo Ekó House. Fonte: Elaborado a partir de PROJETO EKÓ HOUSE, 2012.

\footnotetext{
78 http://apps1.eere.energy.gov/buildings/energyplus/

79 Os equipamentos e eletrodomésticos utilizados foram definidos com base no regulamento do SDE 2012, visando obter as melhores pontuações na prova de operação do protótipo (House Functioning).
} 
Com um consumo médio mensal estimado em $722 \mathrm{kWh}$, o protótipo conta com equipamentos ainda pouco comuns nos domicílios brasileiros, como fogão elétrico e a máquina de secar roupas, sendo que o fogão elétrico apresenta a maior participação no consumo mensal do protótipo, cerca de um quarto do total ${ }^{80}$. O consumo do sistema de condicionamento de ar também responde por uma parcela significativa do consumo do protótipo. Isso se deve, em parte, ao objetivo de cumprir com regras que determinavam que a temperatura interna deveria ser mantida entre $23^{\circ} \mathrm{C}$ e $25^{\circ} \mathrm{C}$, para obtenção da máxima pontuação.

Com relação ao consumo estimado para o protótipo, cabe observar que, embora as simulações busquem uma aproximação a uma situação de ocupação, podem ocorrer variações significativas em relação ao que se observaria em uma condição real. No caso da demanda de eletricidade projetada para o protótipo Ekó House, observa-se no gráfico da Figura 3.39 que a curva de consumo se mantem constante ao longo do ano, resultado dos parâmetros de consumo e calendário de ocupação definidos para as simulações realizadas.

Cabe ainda ressaltar que a presença de eletrodomésticos como o fogão elétrico, e os parâmetros utilizados nos cálculos de consumo de eletricidade caracterizam um padrão de consumo de países desenvolvidos. Mesmo assim, o consumo médio mensal estimado para o protótipo é inferior ao de domicílios de países desenvolvidos como Espanha e Estados Unidos ${ }^{81}$.

O SFV do protótipo garante um balanço energético positivo ao longo de todo o ano. A geração média mensal é de 1752 kWh. Com isso, são exportados para a rede 1030 kWh/mês, em média. O gráfico na Figura 3.39 apresenta a relação entre geração e consumo de energia elétrica ao longo de um ano de operação do protótipo Ekó House.

\footnotetext{
80 Entende-se que gerar energia elétrica para, posteriormente, convertê-la em energia térmica, pode não ser a alternativa mais racional e eficiente, especialmente em países onde a energia elétrica é provida em grande parte por usinas termelétricas. Entretanto, para atender ao regulamento da competição SDE, foram adotados o fogão e forno elétricos como eletrodoméstico para cocção de alimentos.

81 Conforme dados apresentados no Capítulo 2, os consumos médios mensais em domicílios na Espanha e nos Estados unidos são, respectivamente, $876 \mathrm{kWh} / \mathrm{mês}$ e $958 \mathrm{kWh} / \mathrm{mês}$.
} 


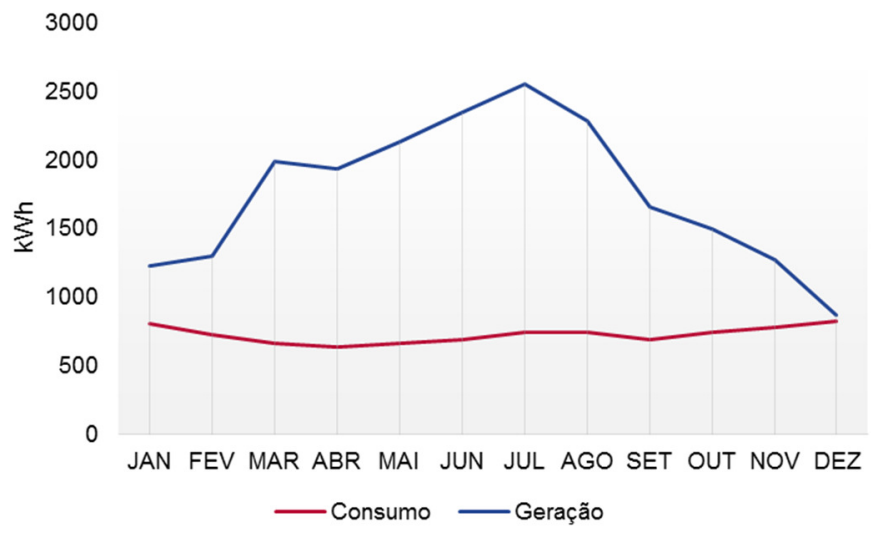

Figura 3.39: Balanço energético anual do protótipo Ekó House Fonte: Projeto Ekó House, 2012.

Durante o SDE foram registrados dados de geração e consumo de energia do protótipo Ekó House. Durante a competição, a casa era operada somente para atender às provas de desempenho de equipamentos e conforto ambiental, o que não reflete a ocupação regular de um domicílio. Entretanto, estas medições demonstram que o protótipo, no período em que foi testado, apresentou um balanço energético positivo. Os dados referentes a estas medições são apresentados no gráfico da Figura 3.40.

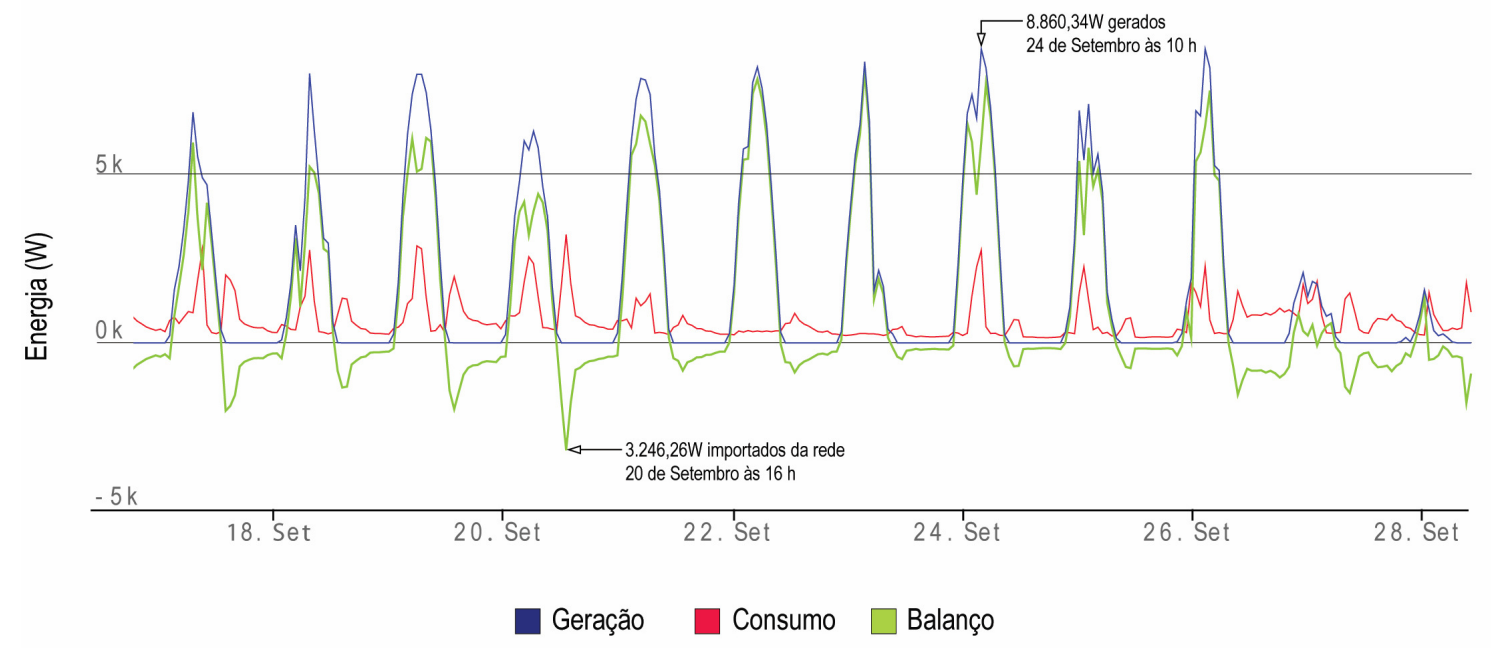

Figura 3.40: Medições de geração e consumo de eletricidade no protótipo Ekó House durante o SDE 2012. Fonte: SDE, 2012.

O protótipo Ekó House adota um sistema de automação residencial. O objetivo principal desse sistema é prover dados de consumo e geração de energia elétrica, água fria e quente, para que os ocupantes tenham acesso a estes dados e possam adotar estratégias visando um consumo mais racional destes recursos. A este sistema estão associados sensores internos que medem temperatura, iluminância e detectam presença de pessoas no interior do protótipo. Desta forma, o sistema pode ser programado para controlar persianas internas, externas, iluminação artificial e ar 
condicionado com base em faixas de conforto pré-estabelecidas, visando a eficiência no consumo de eletricidade.

O sistema conta ainda com uma estação meteorológica localizada na cobertura do protótipo que lança informações sobre previsão do clima. Desta forma, os ocupantes podem planejar suas atividades para quando a relação entre geração e consumo de energia, ou aquecimento e uso de água quente, for mais favorável. Não foram realizadas análises e simulações considerando especificamente o potencial de contribuição deste sistema para a eficiência energética do protótipo. Tampouco o sistema chegou a ser programado e operado completamente no período da competição.

\subsection{Sistematização das premissas e estratégias para uma Casa Solar}

Distintas são as premissas e estratégias para aproveitamento do sol na arquitetura de uma Casa Solar, sejam elas soluções de projeto ou sistemas que venham a ser incorporados à edificação. Conforme descrito ao longo deste capítulo, e demonstrado por meio do protótipo Ekó House, estas estratégias se relacionam entre si, interferindo umas nas outras, bem como no resultado da edificação como um todo. Além disso, muitos fatores podem limitar a aplicação dessas premissas e estratégias, sejam eles econômicos, culturais, técnicos, tecnológicos, ou outros. É importante enxergar de forma sistêmica as possíveis estratégias a serem adotadas e as interfaces entre elas, de modo a obter uma maior eficiência energética e qualidade ambiental como resultado, dentro das limitações de cada projeto.

O diagrama apresentado na Figura 3.41 parte do uso da energia do sol como premissa fundamental no projeto de uma Casa Solar. Em seguida são incorporadas as demandas por energia em uma Casa Solar e, sequencialmente, são acrescentadas ao diagrama as estratégias que podem ser aplicadas para o aproveitamento do sol na arquitetura, incrementando o emprego de tecnologias e a consequente complexidade do projeto.

Quanto mais cedo o aproveitamento do sol na arquitetura for tomado em conta no processo de projeto, como uma diretriz nas escolhas das premissas a seguir e das estratégias a adotar, maiores serão os benefícios decorrentes da utilização deste recurso na arquitetura. 


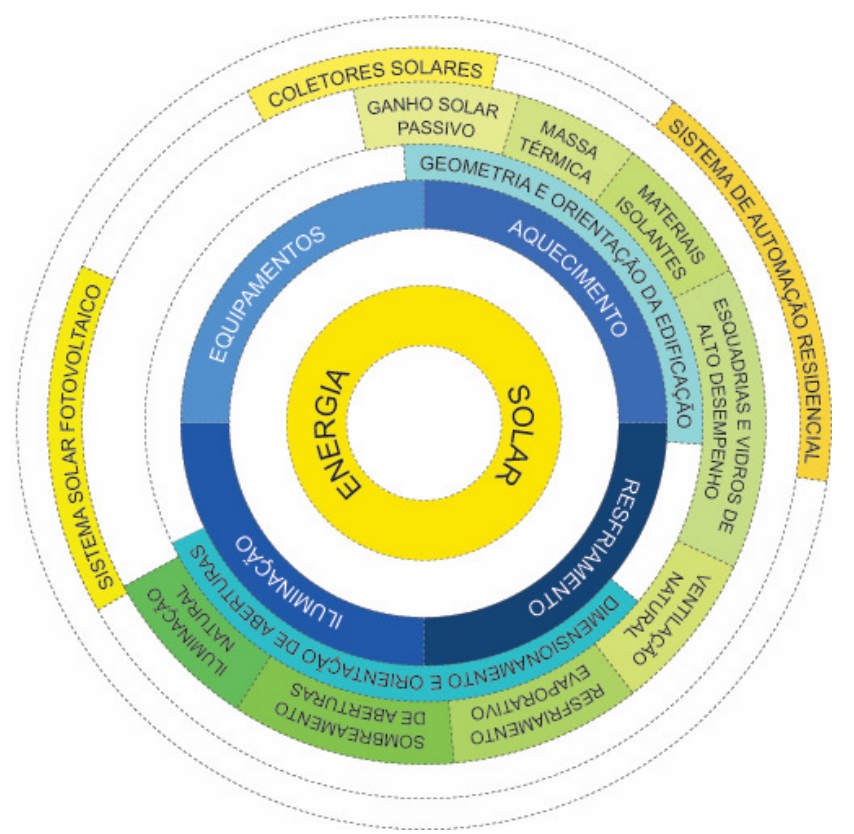

Figura 3.41: Demandas, premissas e estratégias de projeto para uma Casa Solar.

Fonte: Elaboração própria.

Nesta dissertação foram elencadas as premissas e estratégias consideradas as mais relevantes dentro do escopo desta pesquisa. Existe uma infinidade de outras estratégias, ou mesmo derivações das demandas e estratégias apresentadas. Dessa forma, seria possível incorporar a esta estrutura de diagrama novos elementos, aumentando sua complexidade e refinamento quanto à adoção de soluções de projeto para uma Casa Solar.

Sendo assim, partindo do aproveitamento do sol como premissa, uma unidade habitacional pode ser considerada a versão mais elementar de Casa Solar quando concebida considerando um adequado estudo da geometria e orientação solar. Outras estratégias e sistemas podem vir a ser incorporados, por meio de diferentes arranjos e combinações destas soluções, melhorando o desempenho e a eficiência desta unidade. Além disso, preparar a edificação para que estratégias possam ser incorporadas em etapas futuras, por exemplo, deixando esperas para SAS e SFV quando estes não podem ser adotados em um primeiro momento, é também essencial considerando a vida útil de uma Casa Solar.

\subsection{Considerações sobre o capítulo}

Neste capítulo foram apresentadas diversas soluções por meio das quais a arquitetura pode se beneficiar do sol para prover conforto ambiental aos ocupantes e eficiência no 
consumo de eletricidade. A tipologia habitacional unifamiliar, devido a suas características, apresenta facilidade para incorporar muitas das premissas e estratégias apresentadas, desde as que envolvem apenas o estudo da geometria solar e orientação em relação ao sol, até a incorporação de sofisticados sistemas e tecnologias. A abordagem teórica e os exemplos práticos relativos a conceitos bioclimáticos, propriedades de materiais, estratégias de projeto, sistemas solares, equipamentos e tecnologias para a conservação de energia, permitem compreender de forma intuitiva que todas estas soluções, se bem empregadas, contribuem para uma arquitetura de qualidade, para benefício dos ocupantes e do meio ambiente. O protótipo Ekó House foi utilizado para demonstrar a aplicação prática destas premissas e estratégias, bem como as interfaces entre elas. O conteúdo e conceitos apresentados neste capítulo serão aplicados nas análises de dados para estimar o potencial de conservação de energia no setor residencial brasileiro, tanto na provisão de condições de conforto térmico e lumínico, como também para a estimativa da conservação e geração de eletricidade, e a conseguinte contabilização redução de emissões de GEE. 


\section{Aplicação do modelo de Casa Solar no contexto brasileiro}

Este capítulo é dedicado a verificar o potencial de contribuição das soluções e sistemas apresentados no Capítulo 3, e demonstrados por meio do protótipo Ekó House, para a conservação e geração de energia, e a consequente redução de emissões de GEE. Para esta análise, considera-se o cenário brasileiro, delineado no Capítulo 2, com relação aos dados de geração de energia elétrica no SIN e consumo pelo setor residencial. A análise da adoção de estratégias bioclimáticas é qualitativa, estimandose o ganho em horas de conforto pela adoção de estratégias passivas e de baixo consumo. São estimados os ganhos em conservação de energia pela adoção de tecnologias eficientes para iluminação artificial. Para os sistemas solares (SAS e SFV) é feita uma análise quantitativa, que resulta na contabilização da energia gerada com a incorporação destes sistemas a domicílios brasileiros. As estratégias bioclimáticas e os sistemas solares são analisados considerando sua aplicação na cidade de São Paulo. Por fim, as emissões de GEE são contabilizadas por meio dos dados referentes ao potencial de conservação de energia, e geração pelos sistemas solares.

\subsection{Cenário analisado para aplicação de uma Casa Solar no Brasil}

Para estudar a aplicação de uma Casa Solar no Brasil, é adotada como delimitação geográfica a cidade de São Paulo. Trata-se da cidade mais populosa do país, localizada na região Sudeste que, juntamente com a região Sul, apresenta maior potencial de mercado para SFV no país, conforme descrito no Capítulo 2. Dentre os cerca de 3,5 milhões de domicílios, 80\% são unidades unifamiliares (IBGE, 2010), tipologia apontada como bastante favorável para implementar o conceito de REZ no país. Além disso, o fato de ser uma metrópole, figurando entre as maiores do planeta, o uso racional de recursos naturais é um ponto fulcral para garantir a satisfação das necessidades básicas e o bem-estar da população. Devido a estes fatores, a cidade de São Paulo é tomada como exemplo para estimar os benefícios que podem ser obtidos com a conservação e geração de eletricidade por meio da implementação de unidades habitacionais que sejam orientadas por premissas e estratégias de uma Casa Solar, conforme apresentado no Capítulo 3. 
Uma vez definida a cidade a ser estudada, foram analisados os dados climáticos anuais de São Paulo. O gráfico da Figura 4.1 indica as médias anuais de temperatura e umidade para a cidade de São Paulo e as temperaturas máximas e mínimas registradas. As temperaturas médias indicam condições de clima ameno, com temperaturas na faixa dos $20^{\circ} \mathrm{C}$ ao longo do ano. No entanto, as máximas e mínimas absolutas registradas indicam temperaturas no verão próximas aos $35^{\circ} \mathrm{C}$ e, no inverno, chegando próximo a $0^{\circ} \mathrm{C}$. A umidade relativa do ar se mantem entre $75 \%$ e $80 \%$ na maior parte do ano.

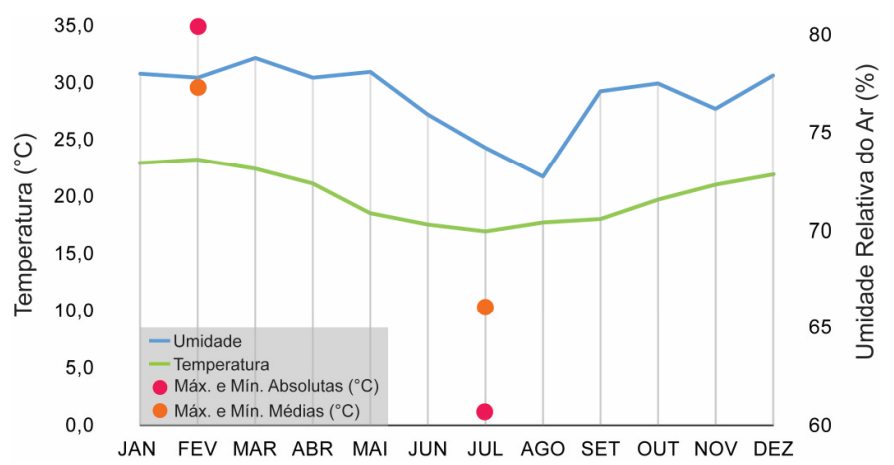

Figura 4.1: Dados de temperatura e umidade para a cidade de São Paulo. Fonte: RETScreen®; INMET, 2014.

Para a análise da radiação solar disponível, alguns outros fatores climáticos podem ser estudados para uma melhor compreensão das médias registradas ao longo do ano. Os gráficos da Figura 4.2 indicam médias mensais de precipitação, nebulosidade e insolação, registradas entre 1961 e 1990.
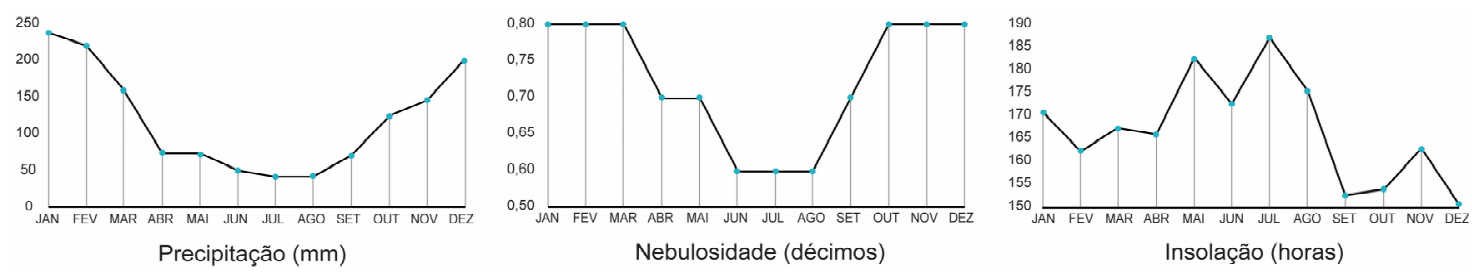

Figura 4.2: Dados de precipitação, nebulosidade e insolação para São Paulo.

Fonte: INMET, 2014.

Desta forma, é possível perceber que entre junho e agosto são registrados os menores índices de precipitação e nebulosidade, resultando em uma alta quantidade de horas de insolação na maior parte da estação de inverno. Os cálculos da radiação solar diária média incidente no plano horizontal e em diferentes orientações de fachadas são apresentados no gráfico da Figura 4.3. 


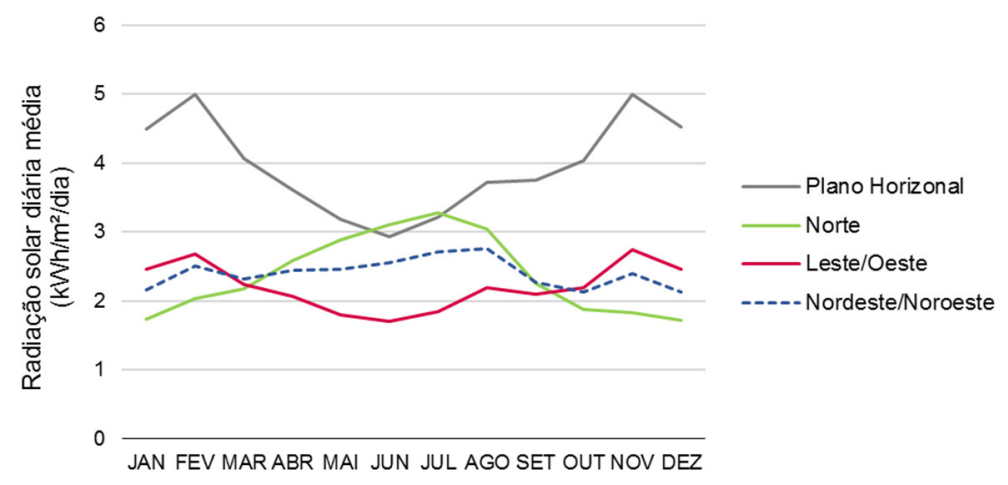

Figura 4.3: Incidência de radiação solar diária média para diferentes orientações em na cidade de São Paulo.

Fonte: Cálculos realizados no RETScreen®.

Observa-se que, em termos de ganhos solares passivos, conforme já descrito no Capítulo 3, a fachada Norte é a mais favorável para o aproveitamento do sol ao longo do ano, por receber maior incidência de radiação durante o inverno, e menor durante o verão. As orientações Leste e Oeste são as menos favoráveis, enquanto as orientações Nordeste e Noroeste apresentam valores intermediários. O plano horizontal é aquele que recebe radiação solar em maior intensidade ao longo do ano. Nos meses de junho e julho a radiação incidente nos planos orientados a Norte supera também a radiação incidente no plano horizontal, em função do movimento do aparente sol.

\subsection{Análise bioclimática e o impacto de estratégias passivas no conforto térmico}

Com relação à adoção de estratégias bioclimáticas, o foco deste trabalho é demonstrar as possibilidades de incorporar estratégias adequadas a um determinado local, neste caso a cidade de São Paulo, para verificar o potencial de se aumentar as horas que conforto em edificações, o que contribui para a redução no consumo de energia destinada ao condicionamento ambiental.

Para tanto, adota-se a ferramenta computacional Climate Consultant $5.5^{82}$, a mesma utilizada nos estudos preliminares para o projeto do protótipo Ekó House. Esta ferramenta foi escolhida por ser disponibilizada gratuitamente, pela possibilidade de utilização dos dados climáticos de São Paulo, e por ser de conhecimento da autora. Além disso, a metodologia de análise da aplicação de estratégias bioclimáticas

82 Ferramenta desenvolvida e disponibilizada gratuitamente pela Universidade da Califórnia (University of California, Los Angeles - UCLA). Os dados climáticos utilizados (formato EPW) são disponibilizados pelo Departamento de Energia dos EUA (DOE). O Climate Consultant 5.5 está disponível no link: $<$ http://www.energy-design-tools.aud.ucla.edu/>. 
apresentada pela ferramenta se mostra bastante propícia às análises desenvolvidas nesta dissertação, cujo foco é verificar o impacto de diferentes estratégias em um contexto abrangente, neste caso, a cidade de São Paulo.

A ferramenta usa como base um banco de dados climáticos que cobre diversas localidades do mundo. Os dados são plotados em uma carta bioclimática, a partir da qual são indicadas as estratégias de projeto mais adequadas para um determinado local. As estratégias indicadas no Climate Consultant 5.5 aplicam os conceitos abordados no Capítulo 3 desta dissertação, e também demonstradas de forma prática na descrição do protótipo Ekó House. A Tabela 4.1 relaciona as estratégias consideradas pela ferramenta Climate Consultant 5.5, indicando as passivas, as de baixo consumo de eletricidade e as ativas.

\begin{tabular}{ccl}
\hline $\mathbf{N}^{\circ}$ & Consumo & Estratégia \\
\hline $\mathbf{1}$ & & Conforto \\
\hline $\mathbf{2}$ & Estratégias para períodos de calor \\
\hline $\mathbf{3}$ & Passiva & Sombreamento de aberturas \\
\hline $\mathbf{4}$ & Passiva & Alta massa térmica \\
\hline $\mathbf{5}$ & Passiva & Resfriamento Evaporativo Direto \\
\hline $\mathbf{6}$ & Baixo Consumo & Resfriamento Evaporativo em dois Estágios \\
\hline $\mathbf{7}$ & Passiva & Resfriamento por Ventilação Natural \\
\hline $\mathbf{8}$ & Baixo Consumo & Resfriamento por Ventilação Forçada \\
\hline $\mathbf{9}$ & & Estratégias para períodos de frio \\
\hline $\mathbf{1 0}$ & Passiva & Ganhos internos de calor \\
\hline $\mathbf{1 1}$ & Passiva & Ganho solar passivo direto com baixa massa térmica \\
\hline $\mathbf{1 2}$ & Passiva & Ganho solar passivo direto com alta massa térmica \\
\hline & Passiva & Proteção de áreas externas contra ventos \\
\hline $\mathbf{1 3}$ & Baixo Consumo & Umidificação \\
\hline $\mathbf{1 4}$ & Ativa & Desumidificação \\
\hline $\mathbf{1 5}$ & & Estratégias mecânicas \\
\hline $\mathbf{1 6}$ & Ativa & Resfriamento e desumidificação se necessário \\
\hline & Aquecimento e umidificação s e necessário \\
\hline
\end{tabular}

Tabela 4.1: Estratégias de projeto apresentadas na ferramenta Climate Consultant 5.5. Fonte: Climate Consultant 5.5.

As análises no Climate Consultant podem ser feitas com base em diferentes modelos climáticos. Para este estudo, optou-se pelo modelo que utiliza os parâmetros do Código de Energia da Califórnia ${ }^{83}$ (California Energy Code), e que é indicado como modelo climático padrão da ferramenta. Como é possível ajustar alguns destes parâmetros,

${ }^{83}$ Optou-se pelo modelo California Energy Code, por ser o que integra de forma mais apropriada as diferentes estratégias de projeto consideradas na ferramenta, mostrando-se o mais adequado a este estudo. 
optou-se por adotar valores que definissem uma faixa de conforto mais ampla do que a faixa pré-definida na ferramenta, visto que o estudo foca na arquitetura residencial, onde o tipo de uso permite maior flexibilidade dos ocupantes quanto a atividades e vestimenta. Givoni (1992) define faixas de temperatura entre 18 e $25^{\circ} \mathrm{C}$ para o inverno, e entre 20 e $27^{\circ} \mathrm{C}$ para o verão. Como as análises são desenvolvidas considerando todos os meses do ano, foram adotados valores de temperatura intermediários aos indicados para cada estação. Para a umidade relativa do ar, adotou-se o valor de $80 \%$. Os valores de umidade relativa para as temperaturas limites são pré-estabelecidos pela ferramenta. A Tabela 4.2 resume os parâmetros considerados nas análises realizadas no Climate Consultant 5.5.

\begin{tabular}{lc}
\hline Parâmetros & Valores \\
\hline Limite inferior de temperatura & $19^{\circ} \mathrm{C}$ \\
\hline Limite superior de temperatura & $26^{\circ} \mathrm{C}$ \\
\hline Máxima umidade relativa do ar & $80 \%$ \\
\hline Umidade relativa do ar para temperatura inferior & $20 \%$ a $30 \%$ \\
\hline Umidade relativa do ar para temperatura superior & $60 \%$ \\
\hline
\end{tabular}

Tabela 4.2: Valores limites de temperatura e umidade. Fonte: GIVONE, 1992; Climate Consultant 5.5.

A carta bioclimática resultante indica o percentual de horas no ano em que se obtêm condições confortáveis pela adoção de cada estratégia isoladamente, ou pela combinação de distintas estratégias. Considerando as condições climáticas da cidade de São Paulo e os parâmetros definidos, a carta psicrométrica gerada no Climate Consultant 5.5 indica que, ao longo do ano, durante $16,8 \%$ das horas as condições climáticas são confortáveis, sem necessidade de qualquer intervenção. Se aplicadas todas as estratégias possíveis, passivas, de baixo consumo de eletricidade e ativas, é possível manter as condições do ambiente interno dentro da faixa de conforto durante 0 ano todo. A Figura 4.4 demonstra a carta psicrométrica com os dados climáticos da cidade de São Paulo, as zonas de conforto e as estratégias relacionadas. 


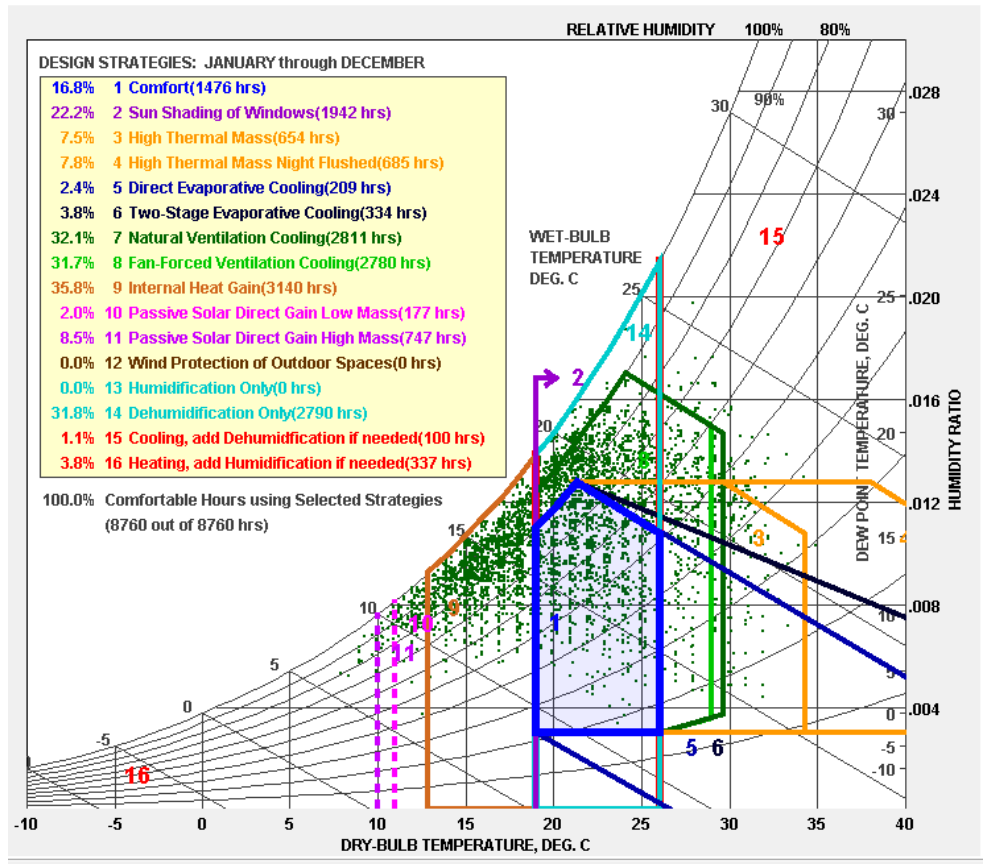

Figura 4.4: Carta psicrométrica gerada para a cidade de São Paulo, para o período de um ano. Fonte: Climate Consultant 5.5.

O gráfico da Figura 4.5 indica o percentual de horas do ano em que cada estratégia se mostra apropriada para a manutenção do conforto ambiental. Como em alguns horários as estratégias se sobrepõem, o que é possível observar na carta bioclimática, o total excede $100 \%$ das horas do ano. As cartas bioclimáticas referentes a cada estratégia para a cidade de São Paulo permitem visualizar mais claramente a associação entre dados de temperatura e umidade e os ganhos em conforto obtidos por cada estratégia. Estas cartas e a descrição de cada estratégia encontram-se no Apêndice C.

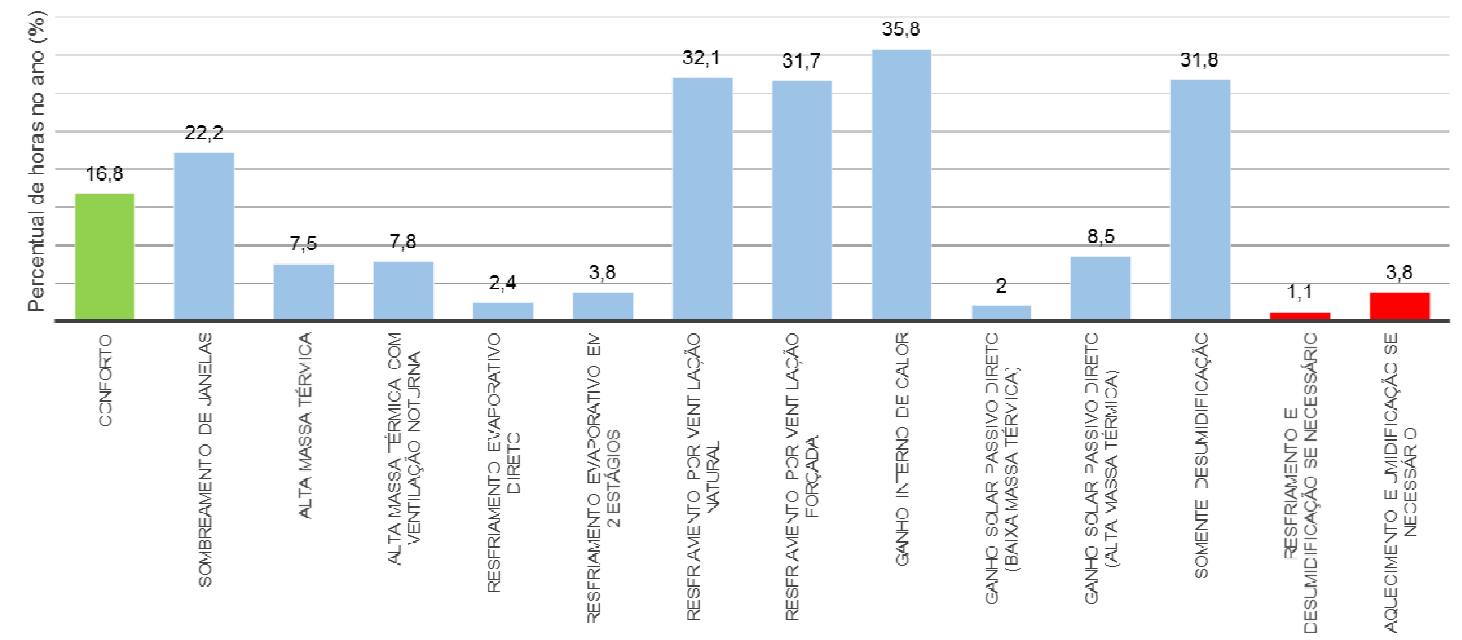

Figura 4.5: Estratégias de projeto e sua efetividade ao longo do ano, em percentual de horas de conforto. Fonte: A partir de cálculos realizados no Climate Consultant 5.5.

A ferramenta Climate Consultant 5.5 permite verificar o percentual de horas de conforto obtidas pela adoção uma estratégia ou um grupo de estratégias. Nem sempre é viável 
aplicar todas as estratégias indicadas em um mesmo projeto, seja por limitações técnico-construtivas, econômicas, características do entorno, ou outros fatores.

As estratégias que preveem a aplicação de materiais com alta massa térmica, por exemplo, muitas vezes não se mostram adequadas à tendência dos novos materiais e componentes construtivos, que vem sendo desenvolvidos buscando estruturas mais leves, muitas vezes pré-fabricadas, de modo a facilitar transporte, manuseio e a construção em si. O protótipo Ekó House exemplifica essas condições, visto que devido à necessidade de transporte, montagem e desmontagem, optou-se por um sistema construtivo mais leve, onde a solução de sobreposição de camadas de isolamento térmico foi priorizada. O emprego de materiais de mudança de fase, os PCM, é uma opção para o aumento da massa térmica de envoltórias leves, porém a disponibilidade desses materiais no Brasil ainda é limitada, o que ainda dificulta o seu uso em escala.

A estratégia de resfriamento evaporativo também pode se tornar inviável em função da necessidade de manutenção ao longo da vida útil dos sistemas utilizados, visto que esta estratégia requer o emprego de elementos como espelhos d'água, aspersores, ou alguma outra solução que possibilite o resfriamento evaporativo do ar antes que este entre na edificação. Já a ventilação natural pode acarretar em problemas como ruídos e poluição do ar, ocasionando desconforto aos ocupantes.

Estratégias como a de ganhos internos de calor mostram-se geralmente ineficazes em edificações de uso residencial, pois a quantidade de calor necessária para aquecer o interior das edificações dificilmente é obtida apenas pelo calor liberado por equipamentos internos e pela atividade metabólica dos ocupantes. Além disso, a ventilação higiênica, necessária para restabelecer condições de salubridade no ambiente, pode remover, juntamente com a renovação do ar, parte do calor acumulado.

Estas situações exemplificam a relevância de se avaliar a implementação de todas as estratégias de forma sistêmica, considerando as estratégias para conforto térmico, lumínico, os sistemas solares e demais equipamentos e sistemas a serem integrados à edificação, além das condições do entorno.

Para a cidade de São Paulo, se excluídas as estratégias que implicam o uso materiais de alta massa térmica, resfriamento evaporativo, ventilação natural e ganhos internos de calor, as horas de conforto do ano são praticamente as mesmas observadas na 
ausência de qualquer estratégia, com um aumento de $2 \%$ no total de horas de conforto no $a^{8}{ }^{84}$, conforme demonstrado na Figura 4.6.
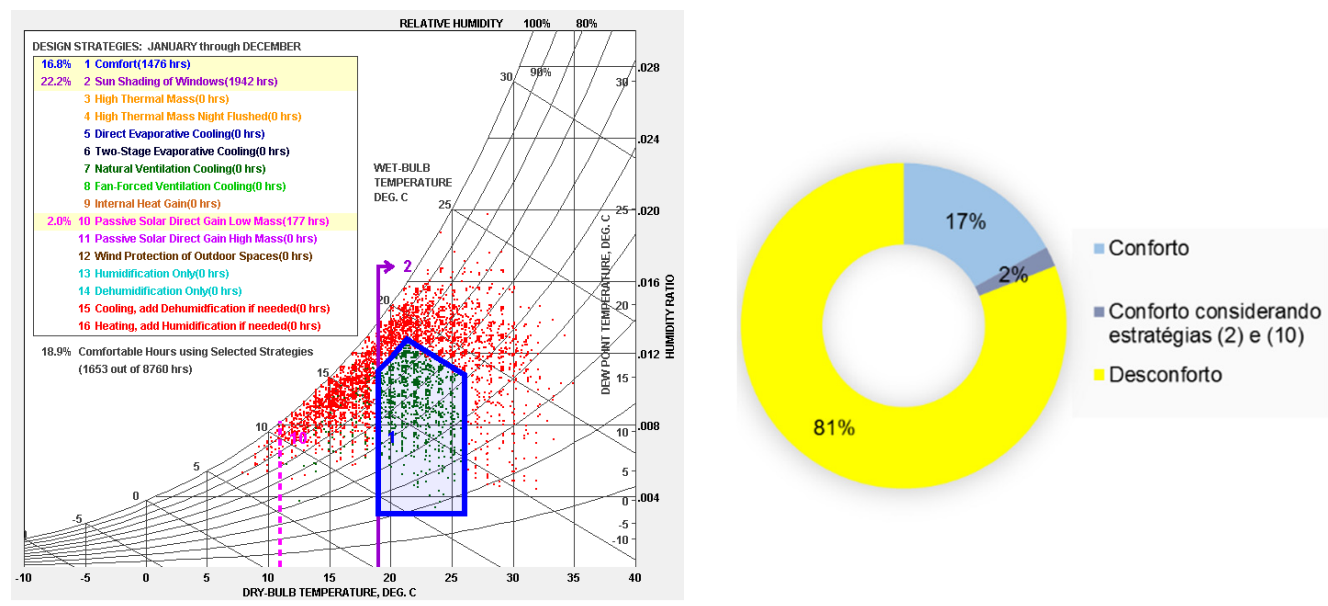

Figura 4.6: Ganho de horas de conforto adotando-se as estratégias (2) sombreamento de janelas, e (10) ganho solar passivo direto com baixa massa térmica.

Fonte: A partir de Climate Consultant 5.5.

Apesar das limitações mencionadas, a tipologia residencial unifamiliar muitas vezes possibilita incorporar técnicas e tecnologias especificas, como materiais de alta massa térmica, com maior facilidade do que as tipologias residenciais multifamiliares, por exemplo. Além disso, muitos bairros apresentam ocupação predominantemente residencial com tipologia unifamiliar. Nessas regiões, geralmente os problemas de ruído e poluição não são tão críticos, e o aproveitamento de ganhos solares passivos é favorecido pela ausência de edificações altas. Cabe analisar as possibilidades e limitações para cada estratégia possível de ser empregara em cada projeto.

Para estimar o potencial de ganhos em horas de conforto por meio de estratégias passivas, foram consideradas somente as estratégias 2, 3, 4, 5, 7, 10 e 11. Com estas estratégias o potencial é de obter $44 \%$ das horas de conforto durante o ano. A Figura 4.7 ilustra estes resultados.

\footnotetext{
${ }^{84}$ Quanto à estratégia (2), de sombreamento de janelas, conforme explanado no Apêndice $C$, trata-se de uma estratégia adequada a cerca de $22 \%$ das horas do ano, mas cujo impacto no conforto térmico não é computado no total de horas de conforto do ano, pois a ferramenta Climate Consultant 5.5 considera que o sombreamento por si só não é capaz de garantir conforto térmico.
} 

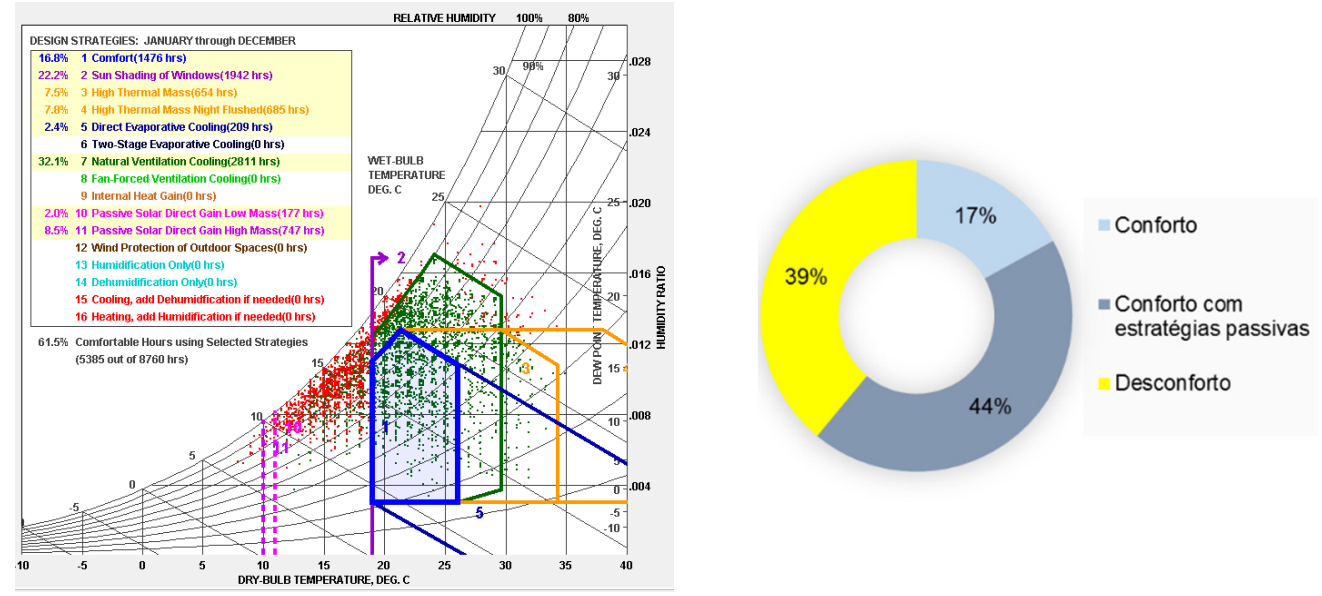

Figura 4.7: Ganho de horas de conforto adotando-se as estratégias 2, 3, 4, 5, 7, 10 e 11, que não requerem consumo de energia, no cenário denominado Climatização $A$.

Fonte: A partir de Climate Consultant 5.5.

Para estimar o potencial máximo de conforto que se poderia obter por meio da adoção de estratégias passivas de baixo consumo de energia, foram desconsideradas somente as estratégias 14, 15 e 16. Neste caso, a estratégia 9, de ganho interno de calor, foi considerada, visto que os ganhos de calor não obtidos pelo uso de equipamentos ou pela atividade metabólica dos ocupantes, poderia ser suprido, por exemplo, por radiadores alimentados por um SAS, configurando uma estratégia de baixo consumo e que utiliza energia renovável, a exemplo do sistema utilizado no protótipo Ekó House. A efetividade desta estratégia implica uma envoltória que assegure o isolamento térmico e a estanqueidade para evitar perdas de calor para o ambiente externo. As soluções construtivas poderiam ser semelhantes às do protótipo Ekó House, demonstradas no Capítulo 3, para uma boa conservação do calor no interior. A Figura 4.8 ilustra este cenário, no qual seria possível alcançar $70 \%$ de horas de conforto no ano pela adoção de estratégias passivas e de baixo consumo de energia.
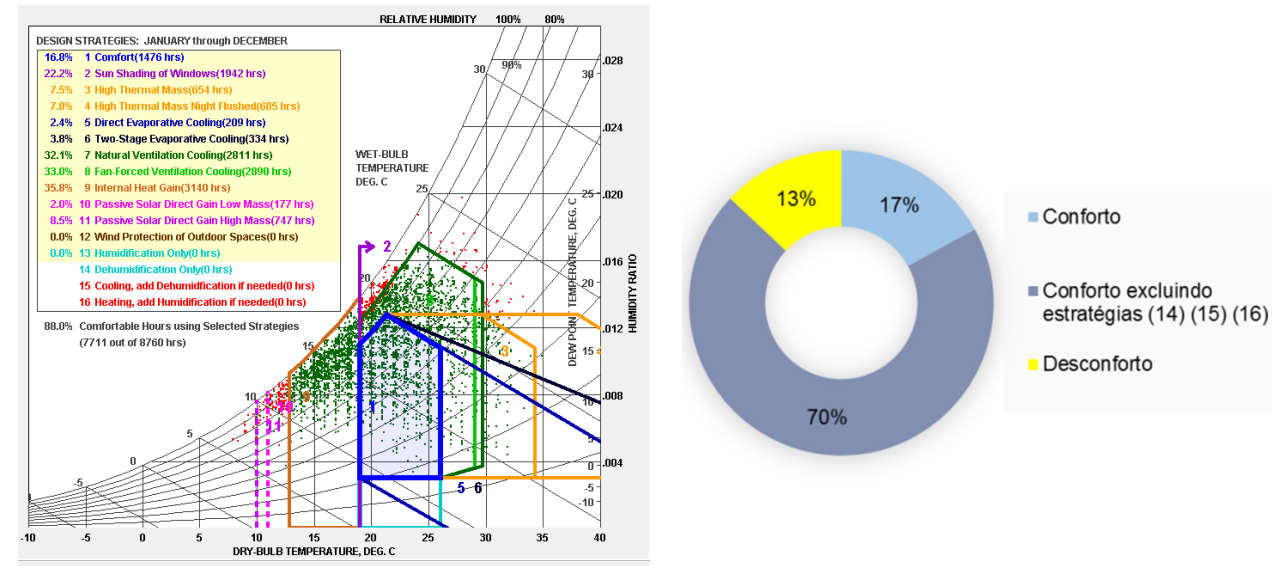

Figura 4.8: Ganhos de horas de conforto no ano agregando-se estratégias de baixo consumo de energia. Fonte: A partir de Climate Consultant 5.5. 
O potencial de aumento nas horas de conforto observado em cada situação analisada demonstra a possibilidade de melhorar as condições de conforto ambiental com conservação da energia destinada ao condicionamento térmico em unidades habitacionais. O consumo de eletricidade destinado à climatização nos domicílios brasileiros deve passar de 42.427 GWh em 2020 para 12.3302 GWh em 2050, um aumento 190\%, conforme demonstrado na Figura 2.20 do Capítulo 2. Fica claro, portanto, o quão essencial é adotar estas estratégias na arquitetura residencial, visando à eficiência energética no condicionamento ambiental e, consequentemente, a melhoria na qualidade ambiental com uma redução no consumo de eletricidade por parte do setor residencial brasileiro.

\subsection{Potencial de conservação de eletricidade para iluminação}

$\mathrm{Na}$ provisão do conforto lumínico, a eficiência energética está associada ao aproveitamento da iluminação natural durante o período diurno e ao desempenho do sistema de iluminação artificial no período noturno. Conforme demonstrado no Capítulo 3 , diversas são as soluções de projeto que podem ser empregadas para se aproveitar adequadamente a iluminação natural, e estas soluções devem também estar integradas às demandas por ganho solar passivo, ou controle desse ganho por meio do uso do elementos de sombreamento de aberturas ou do uso de vidros de alto desempenho.

A maior parte dos estudos dedicados a ganhos em eficiência energética pelo aproveitamento da iluminação natural é direcionada a edifícios de escritórios, onde, diferentemente das edificações residenciais, a ocupação é predominantemente diurna. Neste caso, a análise para estimar o potencial de conservação de energia em unidades habitacionais unifamiliares foi pautada pela comparação entre distintas tecnologias, considerando lâmpadas incandescente, LFC e LED.

Comparando o consumo de energia entre estas diferentes tecnologias de iluminação artificial, com base em dados apresentados no item 3.6.2 do Capítulo 3, é possível observar que as lâmpadas fluorescentes compactas são $75 \%$ mais eficientes do que as incandescentes. Já a tecnologia LED é, cerca de $89 \%$ mais eficiente do que as incandescentes e 57\% mais eficiente se comparada à LFC. A Figura 4.9 ilustra esta diferença no consumo de energia por tecnologia. 

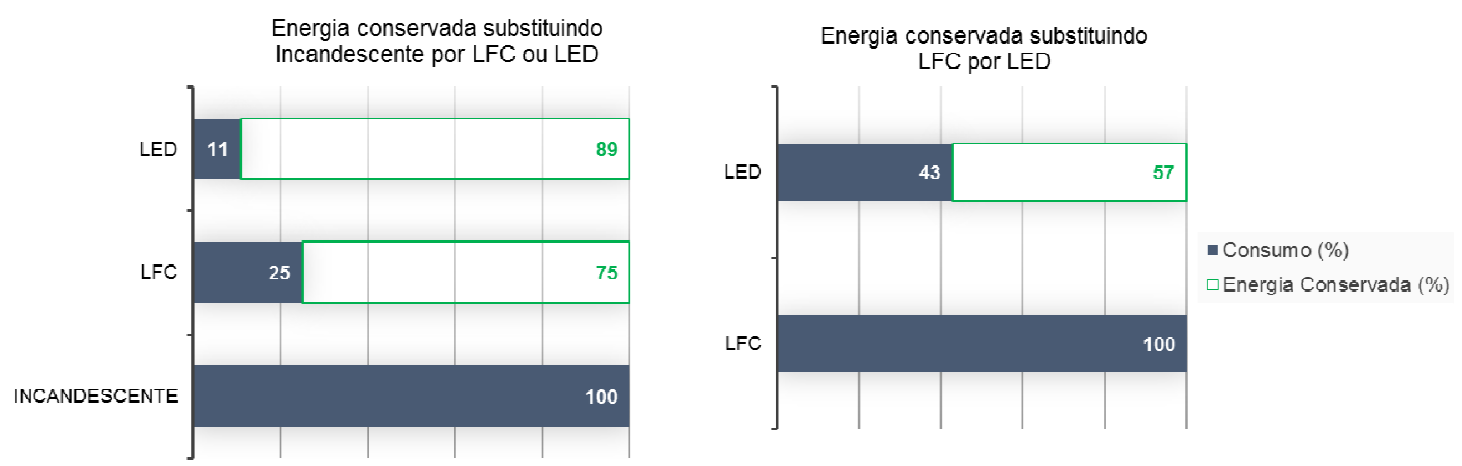

Figura 4.9: Potencial de conservação de energia entre diferentes tecnologias de iluminação artificial. Fonte: Elaborado a partir de DOE, 2012.

Para a análise do potencial de redução de consumo de energia para a iluminação artificial, é considerada a energia conservada quando substituídas lâmpadas incandescentes por LFC e por LED, e LFC por LED. Com a retirada das lâmpadas incandescentes do mercado nacional no ano de 2016, espera-se uma redução mais significativa no consumo de eletricidade associado à iluminação no curto prazo. No longo prazo, conforme demonstrado no Capítulo 2, a tendência é de que a eficiência dos sistemas de iluminação artificial aumente, mas também o número de lâmpadas nos domicílios deve aumentar, associado ao aumento do poder aquisitivo e melhor distribuição de renda da população.

O protótipo Ekó House exemplifica um padrão onde o número de luminárias é bastante superior ao previsto por domicílio, em média, no horizonte de 2050. No entanto, o aproveitamento da iluminação natural, bem como o sistema de automação residencial que serve para controlar a iluminação interna, constituem importantes estratégias na conservação de energia elétrica associada à iluminação, e contribuem de forma significativa para a qualidade ambiental no que se refere ao conforto visual dos ocupantes.

\subsection{Sistemas Solares}

Para estudar a aplicação de sistemas solares na cidade de São Paulo, são analisadas as orientações mais favoráveis, visando obter o maior rendimento destes sistemas ao longo do ano. Os ábacos volumétricos, desenvolvido por Dias (2014), e apresentado no Capítulo 3 desta dissertação, são uma forma de visualizar graficamente as orientações mais favoráveis para o uso de sistemas solares. 
A fim de verificar com maior acuidade a disponibilidade de radiação para a cidade de São Paulo, são obtidos dados de radiação para diferentes orientações por meio da ferramenta computacional RETScreen®. A opção por esta ferramenta se deve ao fato de ela se mostrar adequada às análises a serem desenvolvidas no que se refere à geração de energia por SAS e SFV. Além disso, esta ferramenta é disponibilizada gratuitamente e utiliza como banco de dados informações de estações meteorológicas de diversos locais, incluindo a cidade de São Paulo. O conhecimento prévio da ferramenta por parte da autora também foi um fator determinante para sua escolha.

Para tanto, são utilizados dados climáticos referentes à cidade de São Paulo, e é verificada a radiação solar disponível para as diferentes orientações. São também demonstrados os ganhos que podem ser obtidos por meio de sistemas de rastreamento ${ }^{85}$ do movimento do sol, em um e dois eixos. A Figura 4.10 ilustra estes sistemas de rastreamento.
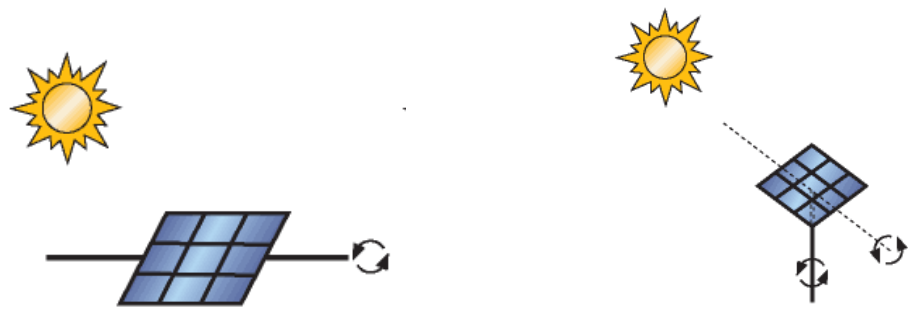

Figura 4.10: Sistemas de rastreamento do sol em um eixo (esquerda) e dois eixos (direita). Fonte: RETScreen®.

O gráfico da Figura 4.11 indica a radiação solar diária média incidente sobre planos orientandos a Norte (N), Leste e Oeste (L/O), Nordeste e Noroeste (NE/NO), com inclinações a $20^{\circ}, 45^{\circ}$ e $90^{\circ}$. A inclinação de $20^{\circ}$ é típica de telhados ou coberturas inclinadas, o que facilita a integração dos sistemas aos planos das coberturas, enquanto a inclinação de $45^{\circ}$ requer o uso de elementos auxiliares de apoio. A inclinação de $90^{\circ}$ sugere a aplicação dos sistemas solares em fachadas. Além disso, é calculada a radiação incidente nos planos de geração considerando o uso de sistemas de rastreamento do sol em 1 eixo. São indicadas também a irradiação incidente em um plano horizontal $\left(0^{\circ}\right)$, e em um sistema de rastreamento do sol em dois eixos.

\footnotetext{
$85 \mathrm{Na}$ ferramenta RETScreen® é possível calcular a radiação incidente em sistemas que rastreiem o sol e um ou dois eixos. Estes sistemas são mais complexos do que os fixos ou sistemas que permitam ajustes, como o aplicado no protótipo Ekó House. O rastreamento do sol pode o correr em um ou dois eixos. No sistema de um eixo, considera-se que que o sistema gira em um eixo geralmente horizontal, Leste-Oeste ou Norte-Sul, de modo a acompanhar o movimento do sol ao longo do dia. No sistema de dois eixos, considera-se que a posição da superfície coletora da radiação solar está sempre ortogonal aos raios de sol. Estes sistemas garantem maior aproveitamento da radiação solar disponível, mas são de custo mais elevado, são automatizados e requerem maior manutenção.
} 


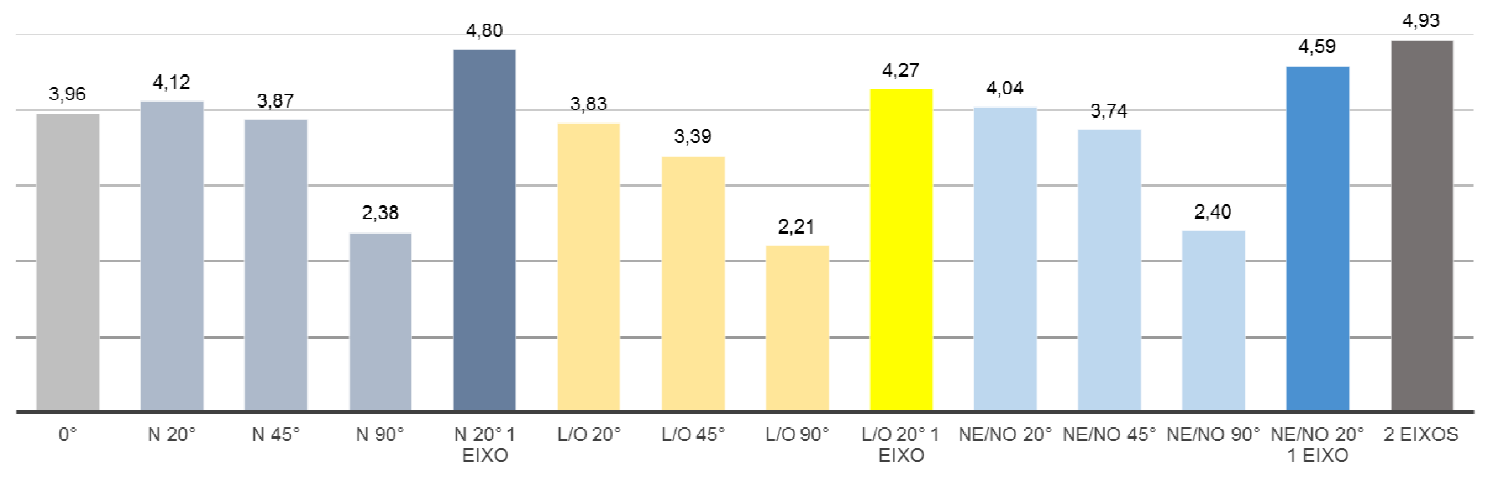

Figura 4.11: Médias anuais de radiação solar diária para a cidade de São Paulo, considerando distintas orientações e inclinações do plano de incidência.

Fonte: A partir de RETScreen®.

No gráfico da Figura 4.11 é possível observar que, considerando sistemas fixos, a orientação Norte é a mais favorável ao longo do ano e que as orientações Leste e Oeste são as menos favoráveis. Nota-se também que sistemas que rastreiam o movimento do sol em um eixo recebem $16,5 \%$ a mais de radiação solar para orientação Norte, $11 \%$ para as orientações Leste e Oeste, e 13,6\% para as orientações Nordeste e Noroeste. Já os sistemas com dois eixos para seguir o movimento do sol podem aumentar em quase $20 \%$ a radiação solar incidente, se comparado à orientação Norte com inclinação de $20^{\circ}$. Em todas as orientações, os planos com $20^{\circ}$ de inclinação (coincidente com a Latitude de São Paulo) são os mais favoráveis, e os com inclinações de $90^{\circ}$ são os menos favoráveis, sendo que para aplicação em fachadas, as orientações mais favoráveis são Nordeste e Noroeste.

Considerando a geração em relação à sazonalidade, é possível observar que em algumas orientações e inclinações, a geração no inverno ultrapassa a geração no verão. Isso ocorre devido ao movimento aparente do sol, descrito no Capítulo 3, fazendo com que a radiação incidente nos planos orientados a Norte, Nordeste e Noroeste, com inclinação de $90^{\circ}$, recebam mais radiação no mês de junho do que no mês de fevereiro, conforme demonstra o gráfico da Figura 4.12. 
Radiação solar diária média nos meses de Fevereiro e Junho para diferentes orientações

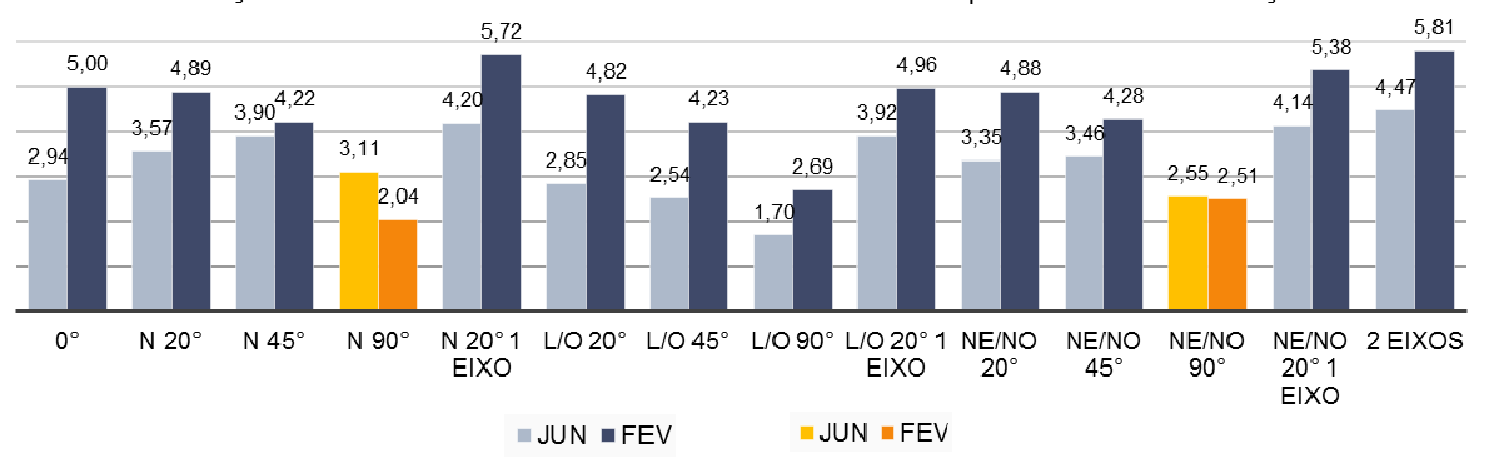

Figura 4.12: Médias mensais de radiação solar diária para a cidade de São Paulo nos meses de fevereiro e junho.

Fonte: A partir de RETScreen®.

Para calcular a geração de energia elétrica e aquecimento de água, são adotadas duas situações, a combinação de orientação e inclinação mais e a menos favorável para a cidade de São Paulo, com relação às médias anuais, considerando a aplicação em coberturas, excluindo-se, portanto, os valores para inclinações de $90^{\circ}$. Sendo assim, os sistemas são orientados a Norte com inclinação de $20^{\circ}\left(4,12 \mathrm{kWh} / \mathrm{m}^{2} / \mathrm{dia}\right)$, e também a Leste/Oeste com inclinação de $45^{\circ}$ (3.39 kWh/m²/dia). Desta forma, é possível demonstrar o impacto da orientação no desempenho dos sistemas solares.

\subsubsection{Sistema de aquecimento solar para aquecimento de água}

Para estimar o aquecimento de água por sistemas solares, e tomando a cidade de São Paulo como local de aplicação destes sistemas, são considerados três sistemas distintos, para atender a diferentes demandas. O primeiro sistema (SAS A) é dimensionado considerando o valor mínimo de 50 litros por pessoa, indicado no RTQ-R (INMETRO, 2012). O mesmo regulamento indica ainda que a temperatura mínima admissível é de $45^{\circ} \mathrm{C}$. Sendo assim, é definido que a temperatura da água aquecida pelo sistema solar deve ser de $50^{\circ} \mathrm{C}$. Adota-se a FS mínima de $40 \%$, estipulada em legislação municipal de São Paulo, decreto no 49.148, de 21 de janeiro de $2008^{86}$, conforme descrito no Capítulo 2.

O segundo sistema (SAS B) considera um volume de 75 litros de água quente por pessoa, considerando uma situação de maior demanda por água quente, que pode ser utilizada também, por exemplo, em eletrodomésticos. Para este segundo sistema,

\footnotetext{
${ }^{86}$ Prefeitura da Cidade de São Paulo. Decreto no 49.148, de 21 de janeiro de 2008. Disponível em: <http://www3.prefeitura.sp.gov.br/cadlem/secretarias/negocios_juridicos/cadlem/integra.asp?alt=2201 2008D\%20491480000>. Acesso em 15/12/2014
} 
considera-se uma FS de 70\%, indicada como valor ótimo para uma boa relação entre dimensionamento e efetividade do sistema (RETScreen $\AA^{87}$; IEA, 2012).

O terceiro sistema (SAS Ekó) representa uma adaptação de estratégias do protótipo Ekó House ao contexto no São Paulo. O volume de consumo é de 75 litros por ocupante, e o dimensionamento do sistema visa obter uma FS mais elevada, de cerca de $85 \%$, para suprir a demanda dos ocupantes e ainda utilizar a água aquecida no condicionamento ambiental no período de inverno, a exemplo do sistema de radiadores a água empregado no protótipo Ekó House. Neste caso específico, a proposta é obter uma maior FS nos meses de inverno.

Os três sistemas são dimensionados para atender a um domicílio com três ocupantes ${ }^{88}$. Os coletores solares utilizados nos três casos são de tubos evacuados. Cada sistema foi simulado com um modelo distinto. As propriedades específicas foram definidas com base nos modelos disponíveis no banco de dados do RETScreen®, e de acordo com cada situação de demanda. A Tabela 4.3 indica os dados de entrada utilizados no cálculo destes sistemas e os resultados de FS obtida para cada situação.

\begin{tabular}{|c|c|c|c|c|c|c|c|c|c|c|c|}
\hline & 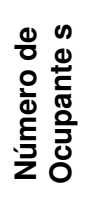 & 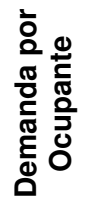 & $\begin{array}{l}\frac{\pi}{\frac{\pi}{0}} \\
\frac{\pi}{\pi} \frac{\pi}{0} \\
\frac{c}{0} \\
\frac{0}{0}\end{array}$ & 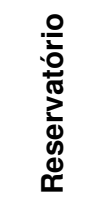 & 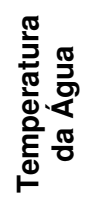 & $\underbrace{\frac{8}{6}}_{\frac{1}{5}}$ & $\frac{\stackrel{8}{5}}{\stackrel{5}{5}}$ & 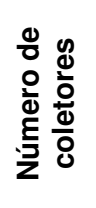 & $\begin{array}{l}\frac{\pi}{0} \\
\frac{0}{0} \\
\frac{8}{0} \\
\frac{2}{4}\end{array}$ & 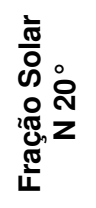 & 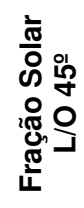 \\
\hline $\begin{array}{c}\text { SAS } \\
\text { A }\end{array}$ & \multirow{3}{*}{3} & $50 \mathrm{~L}$ & $150 \mathrm{~L}$ & $200 \mathrm{~L}$ & \multirow{3}{*}{$50^{\circ} \mathrm{C}$} & 0,31 & 1,16 & 1 & $2,50 \mathrm{~m}^{2}$ & $43 \%$ & $35 \%$ \\
\hline $\begin{array}{c}\text { SAS } \\
\text { B }\end{array}$ & & $75 \mathrm{~L}$ & $225 \mathrm{~L}$ & $250 \mathrm{~L}$ & & 0,54 & 1,04 & 3 & $3,48 m^{2}$ & $68 \%$ & $57 \%$ \\
\hline $\begin{array}{l}\text { SAS } \\
\text { Ekó }\end{array}$ & & $75 \mathrm{~L}$ & $225 \mathrm{~L}$ & $250 \mathrm{~L}$ & & 0,65 & 1,58 & 3 & $4,05 m^{2}$ & $84 \%$ & $71 \%$ \\
\hline
\end{tabular}

Tabela 4.3: Dados de entrada para cálculos de SAS para o município de São Paulo na ferramenta RETScreen®.

Fonte: A partir de RETScreen®.

Com a finalidade de estudar a influência da orientação solar anteriormente demonstrada no desempenho dos SAS, e de demonstrar a fração solar obtida ao longo do ano por

\footnotetext{
87 Esta indicação consta no manual de uso da ferramenta RETScreen®.

${ }^{88}$ Média de membros por família em um mesmo domicílio para a cidade de São Paulo segundo o CENSO 2010 (IBGE, 2010).

${ }^{89} \mathrm{Fr}$ (Ta) é um parâmetro utilizado para caracterizar a eficiência ótica do coletor. Trata-se de um valor sem grandeza física (adimensional) e que varia tipicamente de 0,50 a 0,90. Os valores mais altos são aplicados a coletores planos abertos, os medianos são aplicados a coletores planos fechados, e os valores mais baixos se aplicam a coletores a vácuo (RETScreen®).

${ }^{90} \mathrm{Fr}$ UL é um parâmetro utilizado para caracterizar as perdas térmicas do coletor $\left[\left(\mathrm{W} / \mathrm{m}^{2}\right) /{ }^{\circ} \mathrm{C}\right]$. Os valores variam tipicamente entre 10,0 e $15,0\left(\mathrm{~W} / \mathrm{m}^{2}\right) /{ }^{\circ} \mathrm{C}$ para coletores planos abertos, entre 3,5 e $6,0\left(\mathrm{~W} / \mathrm{m}^{2}\right) /{ }^{\circ} \mathrm{C}$ para coletores planos fechados, e entre 0,7 e $3,0\left(\mathrm{~W} / \mathrm{m}^{2}\right) /{ }^{\circ} \mathrm{C}$ para coletores a vácuo (RETScreen®).
} 
cada sistema, são apresentados os gráficos da Figura 4.13. Os resultados de cálculos realizados no RETScreen ${ }^{\circledR}$ comparam o desempenho anual dos três sistemas para a orientação mais e menos favorável, conforme analisado no item 4.4.

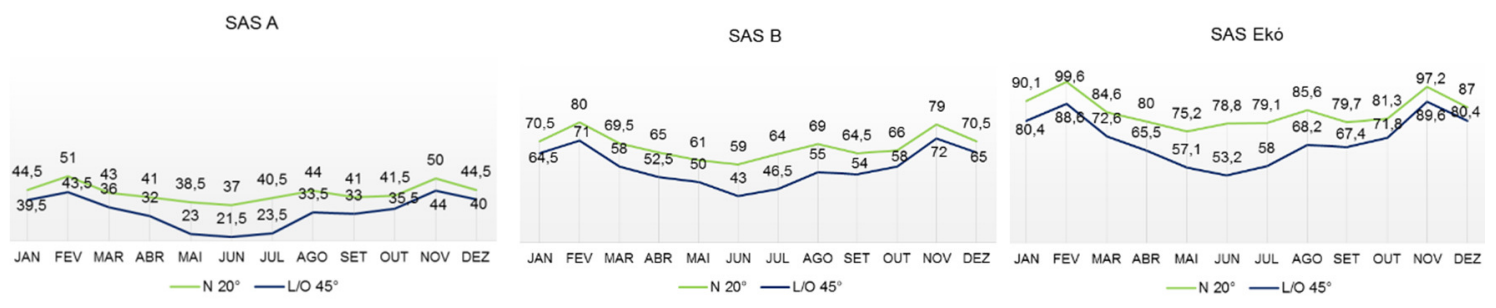

Figura 4.13: Fração solar média mensal (\%) para os SAS calculados para a cidade de São Paulo. Fonte: A partir de RETScreen®.

Nos gráficos da Figura 4.13 é possível observar que na orientação Norte com inclinação de $20^{\circ}$, o rendimento é cerca de $10 \%$ superior ao que se observa para o mesmo sistema orientado a Leste ou Oeste e a $45^{\circ}$ de inclinação, combinação menos favorável, conforme demonstrado nos estudos de radiação solar. Entretanto, em Junho e Julho, meses de menor rendimento dos sistemas, essa diferença no rendimento em função da orientação e inclinação é da ordem de 17\%. Comparando os meses de melhor e pior rendimento para a orientação Norte, a diferença não chega a $14 \%$.

Logicamente, quando não é viável instalar o sistema na orientação mais favorável, por questões de projeto ou mesmo devido ao entorno, o dimensionamento do sistema pode ser ajustado para atender à demanda por água quente. No entanto, muitas vezes em projetos onde se tem a possibilidade de aproveitar as melhores orientações, a incidência da radiação solar ao longo do ano é negligenciada, resultando em perdas no rendimento do sistema e prejudicando a relação custo-benefício para o consumidor.

\subsubsection{Geração de eletricidade por sistema solar fotovoltaico}

A geração solar fotovoltaica foi calculada para a cidade de São Paulo considerando sistemas distintos, que variam em sua capacidade total instalada de modo a adequar 0 dimensionamento dos sistemas a diferentes faixas de consumo. Para estes parâmetros, utilizou-se como referência o estudo desenvolvido pela EPE (2014), que indica a potência instalada típica para distintas faixas de consumo de eletricidade, conforme apresentado na Tabela 2.3 do Capítulo 2. A potência dos SFV foi determinada de forma aproximada, de acordo com os modelos de módulos fotovoltaicos disponíveis no banco de dados do RETScreen®, ferramenta utilizada para o cálculo. Os módulos considerados nos cálculos são de silício policristalino com eficiência de 13,5\% para a 
primeira faixa de consumo e eficiência de $14 \%$ para as demais faixas. Por fim, calculouse também o sistema fotovoltaico do protótipo Ekó House aplicado a São Paulo, cujas características dos módulos foram apresentadas no item 3.7.3.2. do Capítulo 3. Estes valores e as especificações dos sistemas fotovoltaicos aplicados nos cálculos estão indicados na Tabela 4.4.

\begin{tabular}{|c|c|c|c|c|c|c|c|}
\hline $\begin{array}{l}\text { Faixa de } \\
\text { Consumo } \\
\text { (kWh/mês) }\end{array}$ & $\begin{array}{l}\text { Potência } \\
\text { Típica }^{91} \\
\text { (kWp) }\end{array}$ & $\begin{array}{c}\text { Potência } \\
\text { Simulada } \\
(\mathrm{kWp})\end{array}$ & $\begin{array}{c}\text { Eficiência } \\
\text { dos } \\
\text { Módulos } \\
(\%) \\
\end{array}$ & $\begin{array}{l}\text { Número } \\
\text { de } \\
\text { Módulos }\end{array}$ & $\begin{array}{l}\text { Área } \\
\text { Total } \\
\left(\mathbf{m}^{2}\right)\end{array}$ & $\begin{array}{c}\text { Geração N } \\
20^{\circ} \\
\text { (kWh/mês) }\end{array}$ & $\begin{array}{c}\text { Geração } \\
\text { L/O 45ㅇ } \\
\text { (kWh/mês) }\end{array}$ \\
\hline $100-200$ & 1 & 1,08 & 13,5 & 8 & 8 & 129 & 110 \\
\hline $200-300$ & 1,5 & 1,56 & 14 & 12 & 11 & 187 & 159 \\
\hline $300-400$ & 2 & 2,08 & 14 & 16 & 15 & 249 & 212 \\
\hline $400-500$ & 3 & 3,12 & 14 & 24 & 22 & 374 & 319 \\
\hline $500-1000$ & 4 & 4,16 & 14 & 32 & 30 & 499 & 426 \\
\hline$>1000$ & 10 & 10,4 & 14 & 80 & 74 & 1248 & 1064 \\
\hline SFV Ekó & - & 11,04 & 18,5 & 48 & 60 & 1368 & 1167 \\
\hline
\end{tabular}

Tabela 4.4: Potência típica por faixa de consumo, potência utilizada no cálculo e especificações do sistema fotovoltaico adotado.

Fonte: A partir de EPE, 2014; RETScreen®.

A eficiência do inversor (96\%) foi mantida para todas as potências calculadas, pois o objetivo é demonstrar a variação na eficiência conforme a orientação do sistema em relação ao sol, e não por diferença na qualidade de equipamentos que venham a ser utilizados. Da mesma forma, independentemente da eficiência dos painéis, o que determina a quantidade de energia gerada é a capacidade instalada do sistema. Uma maior ou menor eficiência dos módulos vai impactar na área total necessária para que se tenha uma mesma potência instalada. No caso do SFV do protótipo Ekó House, a maior eficiência dos módulos resultou em uma menor área ocupada por módulos e uma geração superior em relação ao SFV de 10,4 kWp.

Ainda com relação às potencias típicas indicadas por faixa de consumo, observa-se que, para a orientação mais favorável, a geração permite uma aproximação a um balanço zero para os limites inferiores das faixas de consumo. Na faixa de consumo mais baixa, para um consumo de $100 \mathrm{kWh}$, o balanço seria positivo mesmo na orientação menos favorável, seguindo a definição de potência típica por faixa de consumo determinada pela EPE (2014).

A diferença na geração de eletricidade observada entre a orientação mais e a menos favorável é da ordem de 15\%. Com isso, é possível observar que mesmo estabelecendo

${ }^{91}$ Potência típica projetada por faixa de consumo (EPE, 2014). 
a potência instalada típica para cada faixa de consumo, o montante de energia gerada pode variar consideravelmente em função da orientação dos sistemas solares. Conforme demonstrado nos estudos de radiação solar para a cidade de São Paulo, uma mesma potência instalada poderia resultar em uma geração ainda maior se o SFV estivesse montado sobre uma estrutura com sistema de rastreamento do movimento do sol, ou consideravelmente menor se aplicada em fachadas (inclinação de $90^{\circ}$ ) e com orientações menos favoráveis, como Leste e Oeste. O gráfico na Figura 4.14 ilustra a geração total anual dos SFV calculados para as diferentes faixas de consumo.

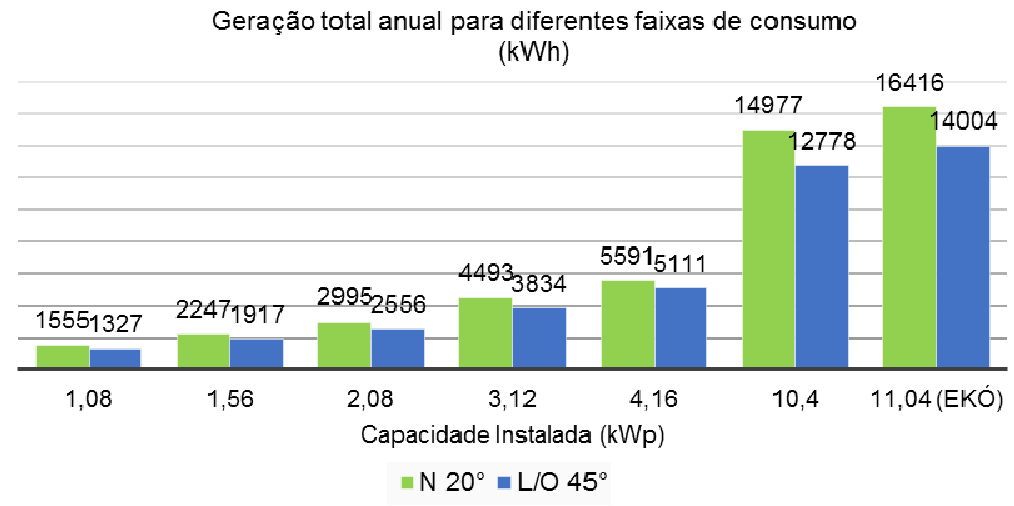

Figura 4.14: Geração total anual dos SFV calculados conforme as faixas de consumo e as potencias típicas indicadas, para distintas orientações.

Fonte: A partir de cálculos realizados no RETScreen®.

Com isso, demonstra-se quantitativamente como o rendimento dos sistemas solares, tanto SAS quanto fotovoltaicos, está associado à orientação solar. Ainda que a diferença no desempenho destes sistemas possa parecer desprezível na escala de um mês ou de um ano de operação, considerando a o horizonte de vida útil destes sistemas, os ganhos (ou perdas) podem somar quantias significativas. Isso impacta no tempo de retorno de investimento (payback) destes sistemas e no potencial de conservação de energia e de se evitar emissões de GEE. Em projetos onde unidades habitacionais são replicadas em larga escala, são também replicadas as perdas ou ganhos de desempenho destes sistemas.

\subsection{Projeção do potencial de redução de emissões de GEE}

As etapas seguintes de análise dizem respeito à estimativa do potencial de redução de emissões de GEE associadas às estratégias para conservação de energia e ao uso de sistemas solares em unidades habitacionais unifamiliares. Para tanto, aplica-se o valor médio de consumo para o setor residencial brasileiro observado no ano de 2013, de 165 kWh/mês. A opção por desenvolver as análises considerando o valor médio de consumo 
por domicilio, ao invés das faixas de consumo apresentadas nas análises para SFV, se deve principalmente aos dados disponíveis referentes ao mercado potencial para SFV e às projeções de adoção de SAS nos domicílios brasileiros, pois as referências bibliográficas utilizadas não trazem valores específicos por faixas de consumo.

Foram definidos também os possíveis dimensionamentos de SFV. Considerou-se que o SFV pode ter capacidade instalada de 1,0 kWp ou 1,5 kWp, e foi assumida a orientação mais favorável à geração de energia elétrica ao longo do ano para o SFV, a Norte e com $20^{\circ}$ de inclinação. A Tabela 4.5 resume estas informações.

\begin{tabular}{lc}
\hline & Domicílio 2013 \\
\hline Consumo médio (kWh) & 165 \\
\hline Faixa de consumo (kWh) & $100-200$ \\
\hline SFV (kWp) & $1,0-1,5$ \\
\hline Geração média (kWh) & $129-187$ \\
\hline
\end{tabular}

Tabela 4.5: Consumo e geração de energia elétrica médios para domicílios brasileiros em 2013.

O consumo de energia elétrica nos domicílios brasileiros, conforme apresentado no Capitulo 2, conta com uma participação de $14 \%$ para a iluminação e $24 \%$ para 0 aquecimento de água. A partir destes percentuais é possível estimar o potencial de conservação da energia elétrica destinada à iluminação artificial e ao aquecimento de água. Para tanto, são adotados os valores de redução no consumo pela adoção de tecnologias mais eficientes para iluminação, indicados no item 4.3, e os valores obtidos nos cálculos para SAS, apresentados no item 4.4.1.

Para a iluminação são consideradas as distintas possibilidades de ganhos em eficiência pela substituição de tecnologias. Para o aquecimento de água, são considerados os SAS A e $B^{92}$, assumindo que estes serão instalados na orientação mais favorável, obtendo frações solares de $43 \%$ e $68 \%$, respectivamente. O gráfico da Figura 4.15 indica os percentuais ${ }^{93}$ de eletricidade que podem ser conservados em relação ao consumo total médio de um domicílio brasileiro.

\footnotetext{
92 Não se considera o SAS Ekó, apresentado no item 4.4.1, pois assume-se que o maior dimensionamento deste sistema é destinado à climatização, conforme descrito no item 4.2.

93 Estes valores foram estimados com base na participação dos equipamentos no consumo residencial brasileiro, apresentados no gráfico da Figura 2.16 do Capítulo 2.
} 


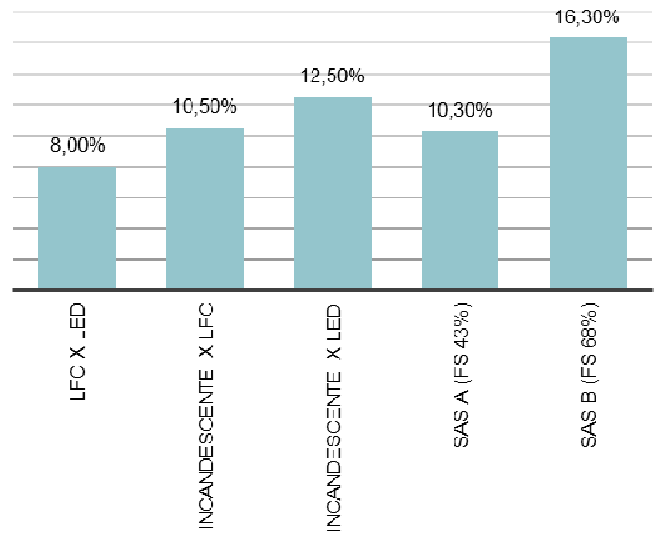

Figura 4.15: Potencial de conservação de eletricidade por estratégia em relação ao consumo médio mensal total de um domicílio.

Com base no potencial de conservação de energia apresentado no gráfico da Figura 4.15, foi possível estimar a conservação de eletricidade se adotadas cada uma das medidas de eficiência energética definidas para estas análises. A Tabela 4.6 indica estes valores.

\begin{tabular}{llcc}
\hline & Estratégia & $\begin{array}{c}\text { Conservação } \\
(\%)\end{array}$ & $\begin{array}{c}\text { Conservação de } \\
\text { Eletricidade* (kWh/mês) }^{*}\end{array}$ \\
\hline \multirow{3}{*}{ Iluminação } & (i1) LFC X LED & 8 & 13,2 \\
\cline { 2 - 4 } & (i2) Incandescente por LFC & 10,5 & 17,3 \\
\cline { 2 - 4 } & (i3) Incandescente por LED & 10,5 & 20,4 \\
\hline SAS A & Fator Solar 43\% & 12,5 & 17 \\
\cline { 3 - 5 } SAS B & Fator Solar 68\% & 10,3 & 26,8 \\
\hline
\end{tabular}

* Relativa ao consumo médio total por domicílio de $165 \mathrm{kWk} / \mathrm{mês}$.

** Mesmo com a retirada das lâmpadas incandescentes do mercado em 2016, considera-se a substituição das mesmas por outras mais eficientes a fim de demonstrar o impacto que legislações mais rigorosas podem ter na conservação de energia elétrica no setor residencial.

Tabela 4.6: Potencial de conservação de energia para domicílios brasileiros em 2013.

A partir dos dados apresentados na Tabela 4.5 e na Tabela 4.6, foi possível estudar o impacto de cada estratégia no consumo final de energia elétrica e no balanço energético, considerando também a geração fotovoltaica. Foram também definidas duas combinações entre estratégias de conservação de eletricidade na iluminação e aquecimento de água, considerando os arranjos mais e menos favoráveis à conservação de eletricidade. A primeira combinação (C1) considera o menor potencial de conservação, combinando a substituição de LFC por LED e a adoção do SAS A, somando um potencial de conservar $18,3 \%$ do total da eletricidade consumida. A segunda (C2) considera a combinação mais favorável à conservação de eletricidade, com a substituição de lâmpada incandescente por LED e a adoção do SAS B, contabilizando uma conservação de energia da ordem de $29 \%$. Desta forma, é possível visualizar o impacto das medidas de conservação de eletricidade no balanço energético. 
$\mathrm{Na}$ Tabela 4.7 são apresentados os dados de consumo, conservação, geração e balanço energético. $O$ valor negativo indica a energia elétrica que foi importada da rede para atender à demanda de consumo, e o valor positivo indica a energia excedente gerada por SFV e exportada à rede elétrica.

\begin{tabular}{|c|c|c|c|c|c|c|}
\hline 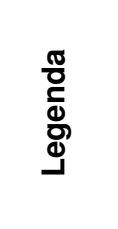 & 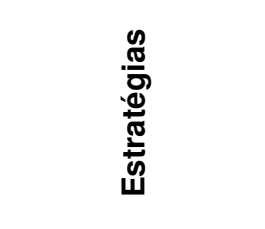 & 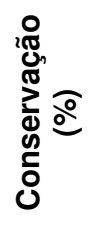 & 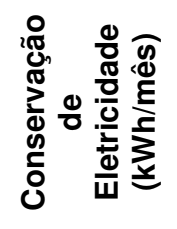 & 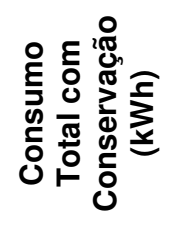 & 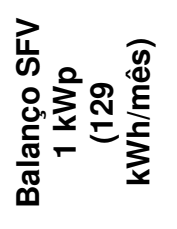 & 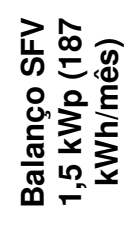 \\
\hline Base & - & 0 & 0 & 165 & \multicolumn{2}{|c|}{-165} \\
\hline $\mathbf{S F V}^{*}$ & & - & - & 165 & -36 & $+22,8$ \\
\hline i1 & LFC X LED & 8 & 13,2 & 151,8 & $-22,8$ & $+35,2$ \\
\hline i2 & $\begin{array}{c}\text { Incandescente } X \\
\text { LFC }\end{array}$ & 10,5 & 17,3 & 147,7 & $-18,7$ & $+39,3$ \\
\hline i3 & $\begin{array}{c}\text { Incandescente X } \\
\text { LED }\end{array}$ & 12,5 & 20,4 & 144,6 & $-15,6$ & $+42,4$ \\
\hline SAS A & FS $43 \%$ & 10,3 & 17 & 148 & -20 & +39 \\
\hline SAS B & FS 68\% & 16,3 & 26,8 & 138,2 & $-9,2$ & $+48,8$ \\
\hline C1 & $\begin{array}{c}\text { LFC X LED + } \\
\text { SAS A }\end{array}$ & 18,3 & 30,2 & 134,8 & $-5,8$ & $+52,2$ \\
\hline C2 & $\begin{array}{c}\text { Incandescente X } \\
\text { LED + SAS B }\end{array}$ & 29 & 47,8 & 117,2 & $+11,8$ & $+69,8$ \\
\hline
\end{tabular}

${ }^{*}$ Considera somente a geração fotovoltaica, sem as estratégias para conservação de eletricidade.

Tabela 4.7: Consumo, conservação, geração e balanço energético.

Observa-se que para a geração de energia resultante de um SFV com a potência típica instalada para a faixa de consumo em questão, as estratégias de conservação de energia permitem uma maior aproximação a um balanço energético zero. No caso da combinação da geração fotovoltaica com o maior potencial de conservação de energia elétrica, o balanço passa a ser positivo dentro dos parâmetros considerados nos cálculos. No caso do SFV com dimensionamento $50 \%$ superior ao da potência típica, é possível obter um balanço positivo mesmo sem adotar estratégias para a conservação de energia. Os gráficos da Figura 4.16 ilustram estes dados. 


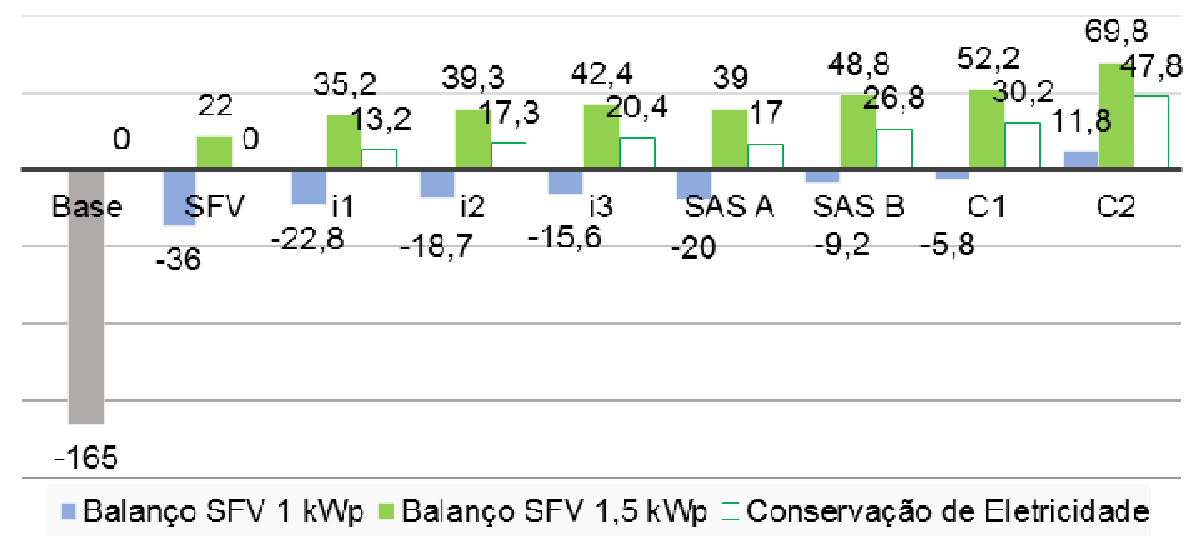

Figura 4.16: Balanço energético resultante da adoção de estratégias para conservação e geração de energia elétrica.

A adoção de um SFV com dimensionamento que resulte em um balanço positivo associado a medidas de eficiência energética é uma estratégia que contribui para aumentar a energia excedente produzida. Para alguns consumidores esta associação pode ser vantajosa, visto que a legislação nacional permite que esta energia seja utilizada posteriormente, ou por outro domicilio, por meio do sistema de compensação descrito no item 2.3.1 do Capítulo 2.

A partir dos valores estimados para conservação e geração de energia elétrica, e com os balanços energéticos resultantes para cada situação analisada, é possível contabilizar as emissões de GEE que poderiam ser evitadas pela adoção destas estratégias. Para tanto, são aplicados os conceitos de projetos de MDL abordados no Capítulo 2. A situação Base é justamente a linha de base que representa as emissões que ocorreriam na ausência do projeto proposto. O projeto proposto, neste caso, consiste na adoção de medidas para conservação e de sistemas solares para a geração de energia elétrica.

Para estimar o potencial de se evitar emissões de GEE, foi aplicado o valor do fator de emissões para o SIN, indicado no Capítulo 2. Para cada kWh gerado no SIN, são emitidos $0,59 \mathrm{~kg}$ de $\mathrm{CO}_{2}$. Conforme descrito nos capítulos 2 e 3, há também emissões de GEE associadas aos SFV. Entretanto, como estas ocorrem nas etapas de manufatura e descarte dos módulos, não havendo, portanto, emissões na operação destes sistemas para geração de eletricidade, considera-se que as emissões associadas aos SFV seriam compensadas pelos fabricantes. Caso contrário, se o consumidor fosse responsável por compensar as emissões do SFV, o fator de emissões do mesmo deveria ser descontado do valor do fator de emissões do SIN. 
As emissões são contabilizadas para cada estratégia de conservação e geração de eletricidade por SFV. Essa contabilização é feita em relação ao cenário Base, que representa as emissões que ocorreriam na ausência das referidas estratégias. O gráfico na Figura 4.17 ilustra os valores calculados para as emissões evitadas. As emissões evitadas são representadas em valores negativos.

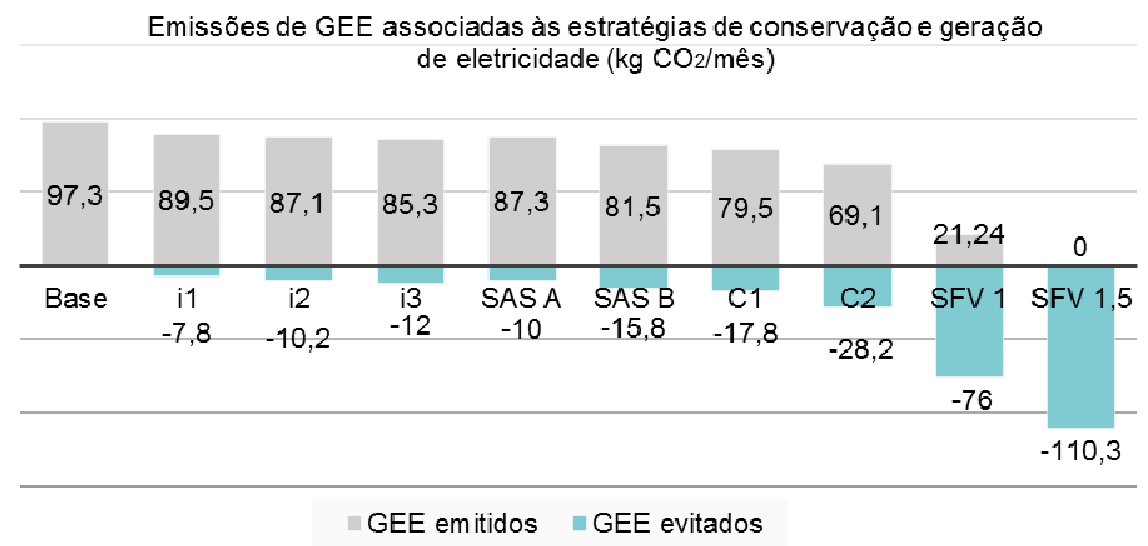

Figura 4.17: Emissões evitadas pela conservação e geração de eletricidade.

Quando as estratégias para conservação de energia são combinadas à geração fotovoltaica, há um aumento na quantidade de emissões evitadas. O gráfico da Figura 4.18 ilustra as emissões que podem ser evitadas quando se associa a geração fotovoltaica às estratégias para conservação de energia, individualmente ou nos dois arranjos previamente definidos.

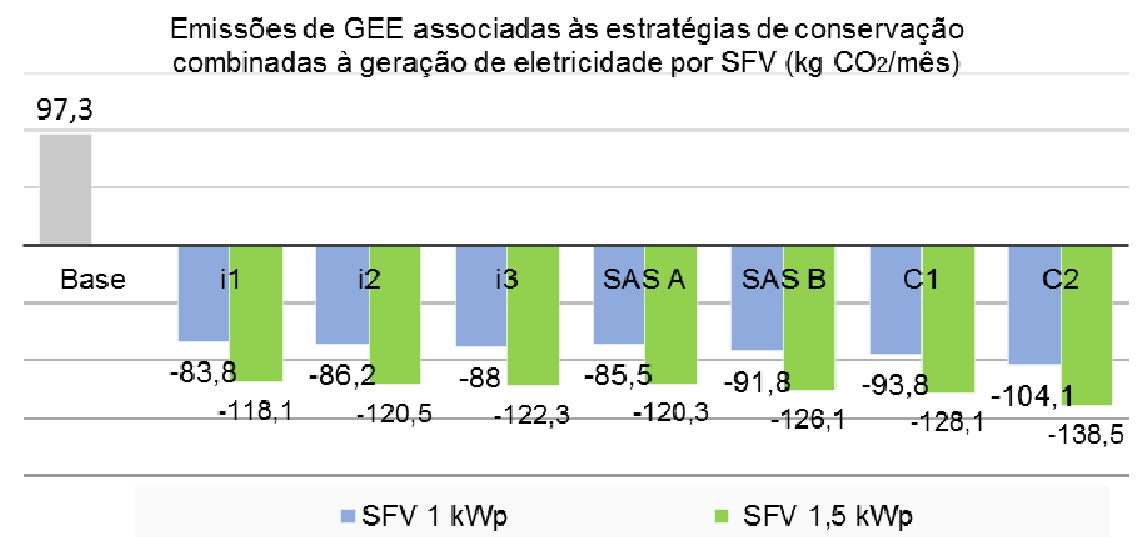

Figura 4.18: Emissões de GEE associadas à combinação de estratégias para conservação e geração de energia, comparadas a um cenário base.

Com base nos parâmetros definidos para estas analises, observa-se um potencial de se evitar entre 7,8 e $12 \mathrm{~kg} \mathrm{CO} 2$ ao mês por unidade habitacional por meio da adoção de tecnologias mais eficientes para a iluminação artificial, entre 10 e $18,8 \mathrm{~kg} \mathrm{CO}_{2}$ ao mês pela da adoção de SAS para geração de energia térmica, reduzindo a demanda por 
eletricidade para aquecimento de água. Os SFV com os dimensionamentos adotados para estas analises apresentam um potencial de evitar emissões de GEE entre 76 e $110,3 \mathrm{~kg} \mathrm{CO}$ por unidade habitacional ao mês, para as potencias de $1 \mathrm{kWp}$ e 1,5 kWp respectivamente. A Tabela 4.8 resume estes valores e indica o quanto se poderia evitar em emissões de GEE ao longo de um ano para cada uma das estratégias nas condições estudadas.

\begin{tabular}{|c|c|c|c|c|c|c|}
\hline \multirow{2}{*}{$\begin{array}{l}\text { Estratégias de } \\
\text { conservação }\end{array}$} & \multicolumn{3}{|c|}{$\begin{array}{c}\text { Contabilização mensal das emissões } \\
\text { de GEE evitadas ( } \mathrm{kg} \mathrm{CO} / \text { mês) }\end{array}$} & \multicolumn{3}{|c|}{$\begin{array}{c}\text { Contabilização anual das emissões } \\
\left.\text { de GEE evitadas (t } \mathrm{CO}_{2} / \mathrm{ano}\right)\end{array}$} \\
\hline & Conservação & $\begin{array}{l}\text { SFV } 1 \\
\text { kWp }\end{array}$ & $\begin{array}{l}\text { SFV } 1,5 \\
\text { kWp }\end{array}$ & Conservação & $\begin{array}{l}\text { SFV } 1 \\
\text { kWp }\end{array}$ & $\begin{array}{c}\text { SFV } 1,5 \\
\text { kWp }\end{array}$ \\
\hline Base & \multicolumn{3}{|c|}{$97,3^{*}$} & \multicolumn{3}{|c|}{$1,16^{*}$} \\
\hline SFV & 0 & 76 & 110,3 & 0 & 0,91 & 1,32 \\
\hline LFC X LED & 7,8 & 83,8 & 118,1 & 0,09 & 1 & 1,41 \\
\hline $\begin{array}{l}\text { Incandescente } \\
\text { X LFC }\end{array}$ & 10,2 & 86,2 & 120,5 & 0,12 & 1,03 & 1,44 \\
\hline $\begin{array}{l}\text { Incandescente } \\
\text { X LED }\end{array}$ & 12 & 88 & 122,3 & 0,14 & 1,05 & 1,46 \\
\hline SAS A & 10 & 85,5 & 120,3 & 0,12 & 1,02 & 1,44 \\
\hline SAS B & 15,8 & 91,8 & 126,1 & 0,19 & 1,1 & 1,51 \\
\hline $\begin{array}{l}\text { LFC X LED + } \\
\text { SAS A }\end{array}$ & 17,8 & 93,8 & 128,1 & 0,21 & 1,12 & 1,53 \\
\hline $\begin{array}{l}\text { Incandescente } \\
\text { X LED + SAS B }\end{array}$ & 28,2 & 104,1 & $-138,5$ & $-0,33$ & 1,25 & 1,66 \\
\hline
\end{tabular}

^Emissões de GEE ocorridas no cenário adotado como linha de base.

Tabela 4.8: Contabilização de emissões de GEE evitadas para uma unidade habitacional, considerando a operação mensal e anual, com base nas emissões contabilizadas para de um cenário base.

\subsubsection{Projeção do potencial de redução de emissões de GEE em escala}

A partir destes valores, é possível projetar os impactos que se poderia obter em termos de redução de emissões de GEE se estratégias para conservação de energia elétrica na iluminação e sistemas solares para geração de energia fossem adotados em escala. A cidade de São Paulo, com 3,5 milhões de domicilio, dos quais $80 \%$, ou 2,8 milhões são unidades unifamiliares, é adotada como cenário para estas projeções.

Os ganhos em conservação de energia e redução de emissões de GEE que podem ser obtidos na iluminação artificial são analisados com base na adoção de tecnologias mais eficientes para este uso final. A substituição de lâmpadas incandescentes deve ocorrer em todo o mercado consumidor brasileiro, por conta da legislação que prevê a retirada dessas lâmpadas do mercado. Portanto, para estudar os ganhos em eficiência energética pela substituição das lâmpadas incandescentes por LFC ou LED, e também pela substituição de LFC por LED, considera-se a adoção destas estratégias em todos 
as unidades habitacionais unifamiliares de São Paulo, mesmo porque, esta reposição tecnológica ocorre naturalmente, seguindo um progresso tendencial. A Tabela 4.9 indica estas projeções.

\begin{tabular}{lcccc}
\hline & \multicolumn{2}{c}{ Conservação de Eletricidade } & \multicolumn{2}{c}{ Emissões de GEE evitadas } \\
\cline { 2 - 5 } & $\begin{array}{c}\text { Por domicílio* } \\
\text { (kWh/mês) }\end{array}$ & $\begin{array}{c}2,8 \text { milhões } \\
\text { de domicílios } \\
\text { (GWh/ano) }\end{array}$ & $\begin{array}{c}\text { Por domicílio* } \\
\text { (t CO2/ano) }\end{array}$ & $\begin{array}{c}2,8 \text { milhões de } \\
\text { domicílios } \\
\text { (t CO } / \text { /ano) }\end{array}$ \\
\hline i1: LFC X LED & 13,2 & 442,8 & 0,09 & 252000 \\
\hline $\begin{array}{l}\text { i2: Incandescente X } \\
\text { LFC }\end{array}$ & 17,3 & 581,2 & 0,12 & 336000 \\
\hline $\begin{array}{l}\text { i3: Incandescente X } \\
\text { LED }\end{array}$ & 20,4 & 685,4 & 0,14 & 392000 \\
\hline
\end{tabular}

*Para um consumo médio de 165 kWh/mês

Tabela 4.9: Projeção de conservação de eletricidade e redução de emissões de GEE pela substituição de lâmpadas incandescentes por LFC e LED.

Para estimar o potencial de adoção de SAS nos domicílios brasileiros, são utilizados dados apresentados no gráfico da Figura 2.18 do Capítulo 2. Para o ano de 2015 a estimativa é de que aproximadamente $5 \%$ dos domicílios adotem SAS. Neste mesmo estudo, a projeção é de que em 2050, 20\% dos domicílios brasileiros possuam SAS instalados. Os SAS já apresentam um tempo de retorno de investimento curto e tem se mostrado economicamente viáveis, inclusive para habitações populares e programas como o MCMV. Portanto, é projetado o potencial de se evitar emissões considerando a adoção de SAS por $5 \%$ e por $20 \%$ das unidades unifamiliares da cidade de São Paulo, no cenário atual de população e consumo de eletricidade. São considerados o SAS A e B para estas projeções. A Tabela 4.10 ilustra o potencial de conservação de energia elétrica e redução de emissões de GEE para estes cenários.

\begin{tabular}{|c|c|c|c|c|c|c|}
\hline & \multicolumn{3}{|c|}{ Conservação de eletricidade } & \multicolumn{3}{|c|}{ Emissões de GEE evitadas } \\
\hline & $\begin{array}{c}\text { Por } \\
\text { domicílio* } \\
\text { (kWh/mês) }\end{array}$ & $\begin{array}{l}\text { 5\% (140 mil } \\
\text { domicílios) } \\
\text { (GWh/ano) }\end{array}$ & $\begin{array}{c}20 \% \text { (560 mil } \\
\text { domicílios) } \\
\text { (GWh/ano) }\end{array}$ & $\begin{array}{l}\text { Por domicílio* } \\
\text { (t CO } \mathrm{CO}_{2} \text { /ano) }\end{array}$ & $\begin{array}{c}5 \% \text { (140 mil } \\
\text { domicílios) } \\
\text { (t CO} / \text { ano) }\end{array}$ & $\begin{array}{c}20 \% \text { (560 mil } \\
\text { domicílios) } \\
\text { (t CO} 2 / a n o)\end{array}$ \\
\hline SAS A & 17 & 28,56 & 114,21 & 0,12 & 16800 & 67200 \\
\hline SAS B & 26,8 & 45,02 & 180,09 & 0,19 & 26600 & 106400 \\
\hline
\end{tabular}

${ }^{*}$ Para um consumo médio de $165 \mathrm{kWh} / \mathrm{mês}$

Tabela 4.10: Potencial de redução de emissões de GEE pela adoção de SAS em São Paulo.

Para estimar o potencial de se evitar emissões pela adoção de SFV em larga escala, são aplicados dados de projeção do mercado potencial para SFV no Brasil, apresentados no item 2.3.2 do Capítulo $2^{94}$. Para o ano de 2016, é estimado um mercado adotante de SFV de $0,02 \%{ }^{95}$ do total de domicílios no país. No horizonte de 2023 é

94 Esses percentuais consideram os cenários mais favoráveis em termos de legislação, mecanismos e incentivos econômicos para a adoção de SFV, conforme apresentado no Capítulo 2

95 Para estimar o percentual de domicílios adotantes de SFV em relação ao número total de domicílios no país, aplicou-se dados de projeções da população disponibilizados pelo IBGE, disponível em: <http://www.ibge.gov.br/apps/populacao/projecao/>. Acesso em: 15/02/2015. 
identificado um mercado potencial adotante de SFV da ordem de $1,5 \%$ do total de domicílios do país. Sendo assim, em um segundo cenário, considera-se a adoção de SFV por $1,5 \%$ das unidades habitacionais unifamiliares de São Paulo no contexto atual quanto à população e consumo médio por domicílio. O potencial de redução de emissões de GEE considerando os parâmetros adotados para SFV e os mercados potenciais identificados para estes sistemas é apresentado na Tabela 4.11.

\begin{tabular}{lccc|ccc}
\hline & \multicolumn{3}{c|}{ Geração de Eletricidade } & \multicolumn{3}{c}{ Emissões de GEE evitadas } \\
\cline { 2 - 7 } & $\begin{array}{c}\text { Por } \\
\text { domicílio } \\
\text { (kWh/mês) }\end{array}$ & $\begin{array}{c}0,02 \%(560 \\
\text { domicílios) } \\
\text { (GWh/ano) }\end{array}$ & $\begin{array}{c}1,5 \%(42000 \\
\text { domicílios) } \\
\text { (GWh/ano) }\end{array}$ & $\begin{array}{c}\text { Por domicílio } \\
\text { (t CO } / \text { ano) }\end{array}$ & $\begin{array}{c}0,02 \%(560 \\
\text { domicílios) } \\
\text { (t CO2/ano) }\end{array}$ & $\begin{array}{c}1,5 \%(42000 \\
\text { domicílios) } \\
\left.\text { (t CO } \mathrm{CO}_{2} / \mathrm{ano}\right)\end{array}$ \\
\hline $\begin{array}{l}\text { SFV } \\
\text { kWp }\end{array}$ & 129 & 0,866 & 65,01 & 0,91 & 509,6 & 38220 \\
\hline $\begin{array}{l}\text { SFV } \\
\mathbf{1 , 5} \\
\text { kWp }\end{array}$ & 187 & 1,256 & 94,24 & 1,32 & 739,2 & 55440 \\
\hline
\end{tabular}

Tabela 4.11: Potencial de geração de eletricidade e redução de emissões de GEE pela adoção de SFV.

Para analisar o impacto da aplicação conjunta em escala das estratégias para conservação e geração de energia elétrica na redução de emissões de GEE, considerase os arranjos de maior e menor potencial de conservação de energia elétrica, associados à geração fotovoltaica. Neste caso, adota-se a projeção mais otimista de percentual de domicílios identificados como possíveis adotantes potenciais de SFV, de 1,5\%. Estas projeções são demonstradas na Tabela 4.12.

\begin{tabular}{lcc|cc}
\hline & \multicolumn{2}{c|}{ SFV 1 kWp } & \multicolumn{2}{c}{ SFV 1,5 kWp } \\
\cline { 2 - 5 } & $\begin{array}{c}\text { Domicílio } \\
\text { (t CO2/ano) }\end{array}$ & $\begin{array}{c}1,5 \%(42000 \\
\text { domicílios) } \\
\left(\mathrm{t} \mathrm{CO}_{2} / \mathrm{ano}\right)\end{array}$ & $\begin{array}{c}\text { Por domicílio } \\
\left(\mathrm{t} \mathrm{CO}_{2} / \text { ano }\right)\end{array}$ & $\begin{array}{c}1,5 \%(42000 \\
\text { domicílios }) \\
\text { (t CO } / \text { /ano })\end{array}$ \\
\hline $\begin{array}{l}\text { C1: LFC X LED + } \\
\text { SAS A }\end{array}$ & 1,12 & 47040 & 1,53 & 64260 \\
\hline $\begin{array}{l}\text { C2: Incandescente X } \\
\text { LED + SAS B }\end{array}$ & 1,25 & 52500 & 1,66 & 69720 \\
\hline
\end{tabular}

Tabela 4.12: Potencial de redução de emissões de GEE pela combinação de estratégias para a conservação e geração de eletricidade.

Analisando as possibilidades aqui estudadas para a conservação e geração de eletricidade em uma unidade habitacional, percebe-se que o potencial de redução de emissões de GEE é notadamente mais elevado nos SFV para geração de eletricidade do que nas demais estratégias, sobretudo quando há geração excedente. Entretanto, ao analisar o potencial de adoção em escala destas estratégias no contexto nacional, e tendo como delimitação a cidade de São Paulo, percebe-se que estratégias de mais baixo custo, e que acabam seguindo uma tendência natural de reposição e atualização tecnológica, podem apresentar um impacto mais significativo, devido aos ganhos de uma aplicação em larga escala, que ainda não é viável para sistemas como os fotovoltaicos. Os gráficos da Figura 4.19 ilustram essas diferenças entre potencial de 
redução de emissões de GEE na escala de uma unidade habitacional, e nas projeções para adoção destas estratégias em larga escala.
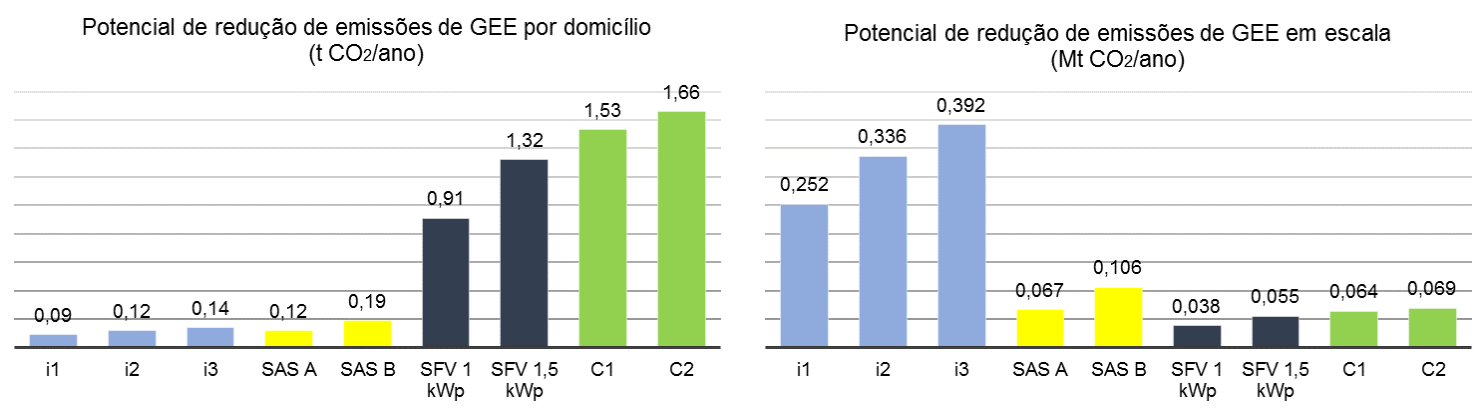

Figura 4.19: Potencial de redução de emissões de GEE pela adoção das estratégias para conservação e geração de eletricidade por unidade habitacional (à esquerda) e em larga escala (à direita).

O potencial de se evitar emissões de GEE observado no caso específico das tecnologias de iluminação artificial, para uma larga escala, demonstra claramente a efetividade de se criar legislações que regulem a eficiência energética de produtos comercializados no país. A retirada das lâmpadas incandescentes do mercado resulta em uma redução de emissões de GEE entre 0,336 e 0,392 $\mathrm{Mt} \mathrm{CO}_{2}$-eq, considerando esta substituição somente nas unidades habitacionais unifamiliares de São Paulo. Estes valores representam entre 1,8\% e 2,17\% do total de emissões de GEE associadas à geração e ao uso de eletricidade pelo setor residencial brasileiro no ano de 2011, que foi de $18 \mathrm{Mt}$ $\mathrm{CO}_{2}$-eq, conforme dados apresentados no Capítulo 2. Os sistemas solares apresentam um potencial ainda mais elevado de reduzir emissões de GEE por unidade habitacional, portanto, sua adoção em escala poderia trazer benefícios significativos na redução do consumo, na geração de energia elétrica e, consequentemente, na redução de emissões de GEE associadas ao uso de energia elétrica no setor residencial brasileiro.

\subsection{Considerações sobre o capítulo}

Neste capítulo foram demonstradas, por meio de analises qualitativas e quantitativas, o impacto da adoção de premissas e estratégias para uma Casa Solar no conforto ambiental, na conservação e na geração de eletricidade em unidades habitacionais unifamiliares. As análises qualitativas desenvolvidas com o auxílio da ferramenta Climate Consultant 5.5 demonstraram o potencial de ganho em horas de conforto no ano por meio da adoção de estratégias passivas e de baixo consumo para o condicionamento térmico ambiental, o que impacta positivamente na conservação de eletricidade para este fim e também na redução de emissões de GEE. A contabilização da conservação e geração de eletricidade considerando a iluminação artificial, 
aquecimento de água e a geração fotovoltaica demonstrou que, na escala da edificação, a adoção de SFV apresenta um potencial bastante superior em evitar emissões de GEE, sobretudo quando associado a estratégias para conservação de eletricidade. Entretanto, considerando a aplicação destas estratégias e sistemas em larga escala, observa-se que no contexto brasileiro, as medidas que dependem de um progresso tendencial para a eficiência energética, a exemplo da substituição de tecnologias para iluminação artificial, apresentam um impacto mais expressivo na conservação de energia e, consequentemente, na redução de emissões de GEE. A análise desenvolvida para a cidade de São Paulo exemplifica premissas e estratégias de projeto que podem ser adotadas para reduzir o consumo de eletricidade e otimizar a geração de energia (térmica e elétrica) por meio de sistemas solares. Dessa forma, é possível mapear soluções de projeto, verificar as interfaces entre estas estratégias, para então estabelecer diretrizes e definir quais premissas e estratégias devem ser priorizadas dentro do contexto e das limitações de cada projeto de Casa Solar. 


\section{Considerações finais}

O presente estudo demonstrou que unidades habitacionais que adotam as premissas e estratégias de uma Casa Solar podem contribuir de maneira determinante para o desenvolvimento sustentável, tanto pelo uso racional e eficiente da energia quanto pela mitigação do aquecimento global, reduzindo emissões de GEE associadas ao uso de energia elétrica em unidades habitacionais.

As análises referentes à geração de eletricidade no Brasil e ao consumo pelo setor residencial brasileiro mostraram um cenário favorável à adoção de medidas para conservação e à geração de eletricidade por fonte solar por parte do setor residencial. Conforme apontado, a tipologia habitacional unifamiliar se mostra bastante propícia à incorporação de sistemas solares para geração de energia e de estratégias passivas para o aproveitamento do sol no condicionamento ambiental. Este aspecto evidencia o potencial do setor residencial brasileiro em contribuir para frear o aumento no consumo de eletricidade projetado para o país, bem como para a expansão da matriz elétrica brasileira com maior participação de fontes renováveis.

O estudo das premissas e estratégias para uma Casa Solar demonstrou que diversas são as alternativas para que soluções adotadas na arquitetura residencial unifamiliar contribuam para a eficiência no consumo de eletricidade, mantendo o bem-estar dos ocupantes. Complementarmente, a análise crítica do protótipo Ekó House exemplificou de forma prática a aplicação destas premissas e estratégias. O protótipo Ekó House, apesar de não refletir o padrão de consumo da maior parte da população brasileira, exemplifica um modelo de casa solar que integra um grande número de soluções, sistemas e tecnologias. O protótipo serviu, portanto, como referencial da aplicação de estratégias para aproveitamento do sol, desde as mais elementares, como o estudo da geometria solar, até a incorporação de sistemas solares e outras tecnologias mais sofisticadas que possibilitam a geração de energia e um consumo mais eficiente em unidades habitacionais.

Os sistemas solares, tanto o fotovoltaico quanto o SAS, mostraram-se favoráveis e bastante oportunos ao cenário brasileiro no que diz respeito à geração e à demanda por energia, inclusive observando os picos de demanda no SIN e as projeções de aumento 
do consumo no horizonte dos anos 2021 e 2050. Foi demonstrado que a integração destes sistemas solares às edificações residenciais unifamiliares vem sendo facilitada do ponto de vista técnico, legal e econômico. Observa-se, entretanto, a necessidade de incentivos econômicos e mecanismos legais devidamente estruturados e que tenham continuidade, para amparar os consumidores interessados em aderir ao uso de sistemas solares, especialmente o SFV.

A geração fotovoltaica distribuída é uma ferramenta com grande potencial para diversificar a matriz de energia elétrica brasileira e contribuir para atender a uma demanda crescente. No caso dos SAS, foi demonstrado o impacto que os coletores solares podem apresentar na redução do consumo de eletricidade se adotados como alternativa ao chuveiro elétrico. Os SAS podem também ser utilizados para o condicionamento ambiental em climas que, como o de São Paulo, apresentam uma demanda significativa por aquecimento para a provisão de conforto térmico aos ocupantes.

Os SFV foram estudados considerando potências instaladas que resultam em uma geração próxima ao consumo médio dos domicílios brasileiros. Foi observado o potencial expressivo de se evitar emissões de GEE por meio da geração de eletricidade através da fonte solar, considerando o balanço energético na escala de uma unidade habitacional. No entanto, as referências adotadas para estimar o mercado potencial dos SFV mostraram uma penetração ainda muito pouco significativa destes sistemas no mercado brasileiro, sobretudo no curto prazo.

No que tange à eficiência energética, observou-se um grande potencial de se melhorar a qualidade das edificações residenciais unifamiliares e reduzir o consumo de eletricidade. O potencial de conservação de energia calculado com base na substituição das lâmpadas incandescentes por tecnologias mais eficientes demonstrou o impacto positivo de legislações que impelem e antecipam mudanças que ocorreriam por meio do progresso tendencial e reposição tecnológica. Foi também observado um potencial igualmente importante para a redução no consumo de eletricidade por meio da adoção de medidas passivas para o condicionamento térmico, bem como pelo uso de SAS como alternativa ao chuveiro elétrico. Todavia, entende-se que são necessárias regulações especificas mais rígidas, que estabeleçam padrões mínimos de qualidade de edificações, e fomentem a adoção de sistemas solares, visando à eficiência no consumo de energia elétrica para a provisão de conforto ambiental aos ocupantes. Tais medidas poderiam impactar de forma expressiva na conservação de energia por parte setor residencial. 
Neste contexto, a contribuição deste estudo consistiu em identificar e demonstrar premissas e estratégias para uma Casa Solar, aplicáveis a uniadades habitacionais unifamiliares, visando atingir padrões satisfatórios de conforto para os ocupantes de forma eficiente, demonstrando alternativas para que o setor residencial brasileiro se desenvolva sem necessariamente aumentar os impactos ao meio ambiente associados ao consumo e geração de energia elétrica.

\subsection{Conclusões}

As análises qualitativas referentes à adoção de estratégias bioclimáticas passivas e de baixo consumo na arquitetura demonstraram um potencial de aumentar em até $70 \%$ as horas de conforto no ano. As análises quantitativas demonstraram um potencial de conservação de energia entre $8 \%$ e $12,5 \%$ para a iluminação artificial por meio da adoção de tecnologias mais eficientes, e entre 10,3\% e 16,3\% para o aquecimento de água pela adoção de SAS como alternativa ao chuveiro elétrico. A combinação destas estratégias resultou em potenciais de conservar entre 18,3\% e $29 \%$ da eletricidade total consumida por mês em um domicilio, sendo que para um consumo médio de 165 $\mathrm{kWh} / \mathrm{mês}$, a conservação poderia variar entre $30,2 \mathrm{kWh} / \mathrm{mês}$ e $47,8 \mathrm{kWh} / \mathrm{mês}$.

A geração de eletricidade por SFV, analisada segundo a indicação de potência típica por faixa de consumo, demonstrou potencial para suprir boa parte da demanda por eletricidade por faixa de consumo, sendo que, conforme demonstrado nas análises para um domicilio com consumo médio, a adoção de medidas para conservação de energia em conjunto com a geração fotovoltaica contribui para que o balanço energético fique próximo a zero ou seja positivo. Tanto para o SFV quanto para o SAS, foi demonstrado o impacto da orientação solar no desempenho destes sistemas, resultando em diferenças da ordem de 15\% no rendimento em função da orientação, o que interfere de maneira substancial no balanço energético para os SFV e na FS para os SAS, e isso impacta também no tempo de retorno de investimento destes sistemas.

Com relação às emissões de GEE, as análises realizadas demonstraram um potencial significativo tanto pela adoção de medidas para conservação de eletricidade quanto por parte dos sistemas de geração de energia. Quando a redução de emissões de GEE é analisada na escala de uma unidade habitacional, observa-se um potencial bastante superior dos SFV em relação às demais estratégias estudadas, sobretudo quando o SFV adotado possui uma capacidade instalada que permite uma geração superior ao consumo. Para uma unidade habitacional com consumo médio brasileiro, as emissões 
evitadas podem variar entre 0,09 t CO $2 /$ ano e 1,51 t CO 2 /ano, dentro dos parâmetros definidos e considerando as diferentes situações analisadas para a conservação e geração de eletricidade.

A análise da aplicação destas estratégias e sistemas em escala, tomando como base dados que apontam as tendências de adoção de sistemas solares nos domicílios brasileiros, mostra projeções ainda bastante inexpressivas, especialmente no caso dos fotovoltaicos. Frente ao potencial demonstrado pelos sistemas solares em contribuir na conservação e geração de energia, mostra-se fundamental um maior incentivo para potencializar a adoção destes sistemas em maior escala no país, tanto economicamente quanto do ponto de vista de legislações especificas.

No longo prazo, a dependência de fontes não renováveis pode ser considerada insustentável do ponto de vista social, econômico e ambiental. A geração solar distribuída não implica impactos socioambientais, como ocorre na instalação de usinas de porte, a exemplo das hidrelétricas ou termelétricas. A geração solar distribuída aproxima geração e consumo, reduz perdas nas etapas de transmissão e distribuição, e contribui para a eficiência do SIN como um todo. Caberia, entretanto, analisar mais detalhadamente as vantagens e limitações de uma intensificação da fonte solar na matriz de energia elétrica brasileira do ponto de vista técnico, legal e econômico.

No atual contexto brasileiro, adotar de forma completa as premissas e estratégias de uma Casa Solar pode não ser uma alternativa viável para grande parte da população. No entanto, foi demonstrado que unidades habitacionais podem incorporar soluções mais elementares, que partem do estudo da geometria solar, passando por inúmeras estratégias bioclimáticas, e podendo incorporar sistemas de baixo custo, como algumas tecnologias de SAS disponíveis. Dessa forma, demonstrou-se possível promover a eficiência energética e uma melhoria na qualidade ambiental de unidades habitacionais sem que isso implique, necessariamente, em grandes investimentos. No contexto do setor residencial brasileiro, mesmo com ações mais pontuais, os ganhos podem ser significativos pela escala que tendem a atingir em se tratando de soluções mais simples e acessíveis.

A análise crítica do protótipo Ekó House demonstrou que é viável incorporar as premissas e estratégias de uma Casa Solar a unidades habitacionais, e que estas premissas e estratégias são essenciais na provisão do conforto ambiental aos ocupantes. O protótipo exemplificou de forma aplicada o impacto que essas premissas e estratégias têm na qualidade do ambiente e também na eficiência energética. Além 
disso, a complexidade do protótipo evidenciou a importância de uma visão sistêmica dessas premissas e estratégias, para sua adequada integração ao projeto arquitetônico.

Cabe ainda mencionar que, independentemente do aquecimento global, as premissas e estratégias apresentadas ao longo desta dissertação e demonstradas por meio do protótipo Ekó House mostraram ser benéficas e favoráveis ao meio ambiente e à sociedade, frente a questões que são evidentes, como a crise energética, a escassez de recursos e os impactos sociais e ambientais associados à geração de energia. As premissas e estratégias pra uma Casa Solar demonstraram que a arquitetura pode responder de uma forma inteligente e racional ao clima e ao aproveitamento do sol, melhorando o conforto dos ocupantes de e promovendo a eficiência energética.

Destas análises e resultados, conclui-se que unidades habitacionais nos moldes de uma Casa Solar podem contribuir de forma expressiva na conservação da energia consumida pelo setor residencial, no aumento da participação de fontes renováveis na matriz de energia elétrica brasileira, na redução de impactos ambientais associados à geração e consumo de eletricidade, e na mitigação do aquecimento global por meio da redução de emissões de GEE. Portanto, estas soluções constituem um fator determinante para o desenvolvimento sustentável do país e evidenciam o potencial do setor residencial brasileiro em contribuir para a eficiência energética por meio de uma arquitetura bioclimática e responsável, e também para a geração de energia por fonte limpa e renovável, neste caso, a fonte solar.

\subsection{Sugestões para trabalhos futuros}

Nesta dissertação a contabilização das emissões de GEE ficou restrita ao consumo de eletricidade e geração solar na fase de ocupação. Pesquisas futuras podem ser dedicadas a uma análise completa do ciclo de vida de uma Casa Solar, contabilizando a energia consumida na manufatura e transporte dos componentes e materiais construtivos, na construção, operação e finalmente, demolição e reciclagem da edificação. Esta contabilização pode ser feita também tendo como escopo o uso de materiais. O protótipo Ekó House, por exemplo, utiliza a madeira como estrutura, que é um material que fixa $\mathrm{CO}_{2}$ da atmosfera, ao invés de emiti-lo.

Dentro da temática da Casa Solar, pesquisas futuras podem ser desenvolvidas projetando e simulando modelos específicos de Casas Solares, de modo a contabilizar mais precisamente as possibilidades de conservação de energia por meio de soluções 
passivas aplicadas à arquitetura residencial unifamiliar, tendo como base o adequado aproveitamento do sol. A incorporação de tecnologias solares específicas como os refrigeradores e fogões solares pode também ser considerada, de modo a verificar 0 impacto das mesmas no consumo de energia por parte dos domicílios brasileiros.

Estudos futuros podem ser dedicados a uma análise mais completa da adoção de SAS como alternativa não apenas ao chuveiro elétrico, mas aos demais energéticos utilizados no aquecimento de água, de modo a verificar os ganhos em termos de conservação de energia e redução de emissões de GEE.

No âmbito do MDL, pode-se estudar especificamente o potencial de adoção de sistemas solares e mesmo medidas de eficiência energética como projetos de MDL, verificando quais seriam os meios para isto e a viabilidade econômica com base nas tendências do mercado de carbono. 


\section{Referências Bibliográficas}

ASSOCIAÇÃO BRASILEIRA DE NORMAS TÉCNICAS. NBR 15220-1: desempenho térmico de edificações - Parte 1: definições, símbolos e unidades. Rio de Janeiro: ABNT, 2005. 8 p.

NBR 15220-2: desempenho térmico de edificações - Parte 2: métodos de cálculo da transmitância térmica, da capacidade térmica, do atraso térmico, e do fator solar de elementos e componentes de edificação. ABNT, 2005. 29 p.

NBR 15220-3: desempenho térmico de edificações - Parte 3: zoneamento bioclimático brasileiro e diretrizes construtivas para habitações unifamiliares de interesse social. ABNT, 2005. 23 p.

NBR 13.532: Elaboração de projetos de edificações - arquitetura. Rio de Janeiro: ABNT, 1995. 8 p.

NBR 5413: iluminância de interiores. Rio de Janeiro: ABNT, 1992. 13 p.

. NBR 15575: edificações habitacionais- desempenho - Parte 1: requisitos gerais. Rio de Janeiro: ABNT, 2013. 71 p.

. NBR 15215-3: iluminação natural - Parte 3: procedimento de cálculo para a determinação da iluminação natural em ambientes internos. Tio de Janeiro: ABNT, 2005. $36 \mathrm{p}$.

AEMET. Valores extremos - Madrid. Agencia Estatal de Meterología. AEMET, 2014. Disponível em:

\section{$<$} http://www.aemet.es/es/serviciosclimaticos/datosclimatologicos/efemerides_extremos* $? \mathrm{w}=0 \& \mathrm{k}=\mathrm{mad} \& \mathrm{l}=3195 \&$ datos $=\operatorname{det} \& \mathrm{x}=3195 \& \mathrm{~m}=13 \& \mathrm{v}=\mathrm{TMMA}>$. Acesso em 15/06/2014. AMATO, F. Produção de energia por hidrelétricas é a menor desde 2005. G1, Brasília, 8 Set. 2014.2 Disponível em: <http://g1.globo.com/economia/noticia/2014/09/producao-de-energia-por-hidreletricase-menor-desde-200512.html>. Acesso em: 10/09/2014. 
ANEEL. Atlas de energia elétrica do Brasil. Agencia Nacional de Energia Elétrica. 2 ed. Brasília: ANEEL, 2005.

ANEEL. Resolução Normativa ANEEL n. 482, de 17 de abril de 2012. ANEEL, 2012a. Disponível em: http://www.aneel.gov.br/cedoc/ren2012482.pdf

ANEEL. Resolução Normativa ANEEL n. 512, de 11 de dezembro de 2012. ANEEL, 2012b. Disponível em: http://www.aneel.gov.br/cedoc/ren2012517.pdf

ANTONIO, F.; et al. Zero Energy Solar-House Model for Isolated and Environmental Protection Areas in Brazil. In: Passive and Low Energy Architecture - PLEA 2014 Conference: Sustainable Habitat for Developing Societies: Choosing the way forward. Ahmedabad: CEPT University Press, 2014.

BARTRAM, L., WOODBURY, R. Smart homes or smart occupants? Reframing computational design models for the green home. Artificial Intelligence and Sustainable Design. Association for the Advancement of Artificial Intelligence, AAAI 2011 Spring Symposium. California: AAAI, 2011.

BECKER, B., KELLERER, A., SCHMECK, H. User Interaction Interface for Energy Management in Smart Homes. Innovative Smart Grid Technologies (ISGT). IEEE PES, 2012. p. 1-8.

BORBA, J. Ministro admite racionar energia se nível de reservatórios cair a $10 \%$. Jornal Folha de São Paulo, 22 de Janeiro de 2015. Disponível em: <http://www1.folha.uol.com.br/mercado/2015/01/1579104-ministro-admite-racionarenergia-se-nivel-de-reservatorios-cair-a-10.shtml>. Acesso em: 24/01/2015.

BORBA, J., VETTORAZZO, L. Brasil importa energia da Argentina pelo segundo dia consecutivo. Jornal Folha de São Paulo, 22 de Janeiro de 2015. Disponível em <http://www1.folha.uol.com.br/mercado/2015/01/1578754-brasil-importa-energia-daargentina-pelo-segundo-dia-consecutivo.shtml>. Acesso em: 24/01/2015.

BORGES, T. Sintese otimizada de sistemas de aquecimento solar de água. 2000. 139 f. Tese (Doutorado em Engenharia Mecânica) - Universidade Estadual de Campinas, 2000.

BRASIL. Ministério de Minas e Energia, Empresa de Pesquisa Energética. Plano Decenal de Expansão de Energia 2020 - PDE 2020. Brasília: EPE, 2011a. 
BRASIL. Ministério de Minas e Energia, Empresa de Pesquisa Energética. Plano Decenal de Expansão de Energia 2021 - PDE 2021. Brasília: EPE, 2012.

BRASIL. Ministério de Minas e Energia, Empresa de Pesquisa Energética. Plano nacional de eficiência energética: premissas e diretrizes básicas. Brasília: MME, $2011 b$.

BRASIL, Ministério de Minas e Energia, Empresa de Pesquisa Energética. Matriz Energética Nacional 2030. Brasília: EPE, 2007.

BROWN, G. Z.; DEKAY, M. Sol, vento e luz: estratégias para o projeto arquitetônico. Porto Alegre: Bookman, 2004.

BEHLING, S. Sol power: la evolucion de la arquitectura sostenible. Barcelona: Gustavo Gili, 2002.

COMISSÃO EUROPEIA. Energia solar térmica: manual sobre tecnologias, projecto e instalação. Programa ALTENER. Lisboa: COMISSÃO EUROPEIA, 2004.

CORBELLA, O. Em busca de uma arquitetura sustentável para os trópicos conforto ambiental. Rio de Janeiro: Revan, 2003.

CQNUMC. Conferência das partes sobre sua sétima sessão. Marraqueche, 29 de outubro a 10 de novembro de 2001. Convenção-Quadro Das Nações Unidas Sobre A Mudança Climática. Relatório, 2002. Disponível em: <http://www.mct.gov.br/upd_blob/0004/4990.pdf>. Acesso em 02/08/2012.

DIAS, L. S. Incorporação de sistemas fotovoltaicos em envoltórias de edificações: tecnologia e arquitetura. Dissertação (Mestrado em Tecnologia da Arquitetura) Faculdade de Arquitetura e Urbanismo, Universidade de São Paulo. São Paulo: USP, 2014. 144 p.

DOE. What is the energy payback time for PV? U. S. Department of Energy. DOE, 2004. Disponível em: <http://www.nrel.gov/docs/fy04osti/35489.pdf>. Acesso em: 03/06/2014.

DOE. Life-Cycle Assessment of Energy and Environmental Impacts of LED Lighting Products Part I: Review of the Life-Cycle Energy Consumption of Incandescent, Compact Fluorescent, and LED Lamps. U. S. Department of Energy. DOE, 2012.

Disponível

em: 
http://apps1.eere.energy.gov/buildings/publications/pdfs/ssl/2012_LED_Lifecycle_Repo rt.pdf>. Acesso em: 14/04/2014.

DOE/EREC. What's New in Building Energy Efficiency: Selecting Windows for Energy Efficiency. U.S. Department of Energy/ Energy Efficiency and Renewable Energy Clearinghouse. Merrifield: DOE-EREC, 1997.

DORNELLES, K. A. Absortância solar de superfícies opacas: métodos de determinação e base de dados para tintas látex acrílica e PVA. 2008. 160 f. Tese (Doutorado em Engenharia Civil) - Faculdade de Engenharia Civil, Arquitetura e Urbanism, Universidade Estadual de Campinas, Campinas. 2008.

DURAN, S. C. A casa ecológica: ideias práticas para um lar ecológico e saudável. Barcelona: Gustavo Gili, 2011.

ECEEE. Net zero energy buildings: definitions, issues and experience: Steering through the maze \#2. European Council for an Energy Efficient Economy. Stockholm: ECEEE, 2009.

EDWARDS, B. Guia básica de la sostenibilidad. Barcelona: Gustavo Gili, 2004.

EIA. 2009 Residential Energy Consumption Survey. U.S. Energy Information Administration, $\quad 2011.2$ Disponível em: <http://www.eia.gov/consumption/residential/reports/2009/overview.cfm>. Acesso em 03/05/2013.

EMPRESA DE PESQUISA ENERGÉTICA. Análise da inserção da geração solar na matriz elétrica brasileira. Nota técnica. Rio de Janeiro: EPE, 2012.

Anuário estatístico de energia elétrica 2013. Rio de Janeiro: EPE, 2013a.

Avaliação da eficiência energética na indústria e nas residências no horizonte decenal (2010-2019). Nota técnica DEA 14/10. Rio de Janeiro: EPE, 2010.

Balanço Energético Nacional (BEN) 2013: Ano Base 2012. Empresa de Pesquisa Energética. Rio de Janeiro: EPE, 2013b.

Demanda de energia 2050. Estudos da demanda de energia. Nota técnica DEA 13/14. Rio de Janeiro: EPE, 2014.

ESPÍ, M. V. Una brevísima historia de la arquitectura solar. Ciudades para un futuro más sostenible, Boletin CF+S, Numero 9. Madri: Instituto Juan de Herrera, 1999. 
Disponível em: < http://habitat.aq.upm.es/boletin/n9/amvaz.html>. Acesso em: 05/05/2014.

FRONDIZI, I. M. R. L. (organizador). O mecanismo de desenvolvimento limpo: guia de orientação 2009. Rio de Janeiro: Imperial Novo Milênio: FIDES, 2009.

FROTA, A. B.; SCHIFFER, S. R. Manual de conforto térmico. 8. ed. São Paulo: Studio Nobel, 2003.

FTHENAKIS, V. et al. Methodology guidelines on lifecycle assessment of photovoltaic electricity. 2ed. IEA PVPS Task12. Photovoltaic Powersystems Programme, International Energy Agency. IEA, 2011

GALLOWAY, T. Solar house: a guide for the solar designer. Oxford: Architectural Press, 2004.

GALVÃO, L. UDAETA, M. GRIMONI, A. Iniciação a conceitos de sistemas energéticos para o desenvolvimento limpo. Editora da Universidade de São Paulo. São Paulo, 2004.

GIVONI, B. Comfort, climate analysis and building design guidelines. Energy and Buildings, vol. 18, p. 11-23, 1992.

HASTINGS, S. R. Sustainable solar housing: strategies and solutions. Reino Unido: Routledge, 2009.

HAGGARD, K.; BAINBRIDGE, D.; ALJILANI, R. Passive solar architecture pocket reference. International Solar Energy Society (ISES). Earthscan, 2009.

HOUAISS, A. VILLAR, M. de S.; FRANCO, F. M. M. Dicionário Houaiss eletrônico da língua portuguesa. Rio de Janeiro: Objetiva, 2009.

IBGE. Censo Demográfico 2010. Disponível em: http://censo2010.ibge.gov.br/en/. Acesso em 25/10/ 2012.

IDEA. Análisis del consumo energético del sector residencial en España - Informe Final. Secretaría General Departamento de Planificación y Estudios - IDAE, Espanha, $2011 . \quad$ Disponível em: <http://www.idae.es/index.php/mod.documentos/mem.descarga?file=/documentos_Info rme_SPAHOUSEC_ACC_f68291a3.pdf>. Acesso em 03/05/2013 
IEA. Solar energy systems in architecture: Integration criteria and guidelines. International Energy Agency, Solar Heating and Cooling Programme: Task 41, Solar Energy \& Architecture. IEA, 2012.

IEA. Statistics search: indicators for 2011. IEA, 2014. Disponível em: < http://www.iea.org/statistics/statisticssearch/>. Acesso em 10/07/2014.

IEA. Technology Roadmap: Energy efficient building envelopes. International Energy Agency. Paris: OECD/IEA, 2013.

IESNA. The IESNA Lighting Handbook: Reference and Application. 9th edition. Illuminating Engineering Society Of North America. New York: IESNA, 2000.

INMET. Gráficos climatológicos: 1961-1990. Ministério da Agricultura, Pecuária e Abastecimento: Instituto Nacional de Meteorologia. Brasília: INMET, 2014.

em: <http://www.inmet.gov.br/portal/index.php?r=clima/graficosClimaticos>. Acesso em 29/12/2014.

INMETRO. Regulamento Técnico da Qualidade para o Nível de Eficiência Energética de Edificações Residenciais (RTQ-R). Instituto Nacional de Metrologia, Normalização e Qualidade Industrial, Portaria n॰ 018, de 16 de janeiro de 2012. INMETRO, $2012 . \quad$ Disponível em: <http://www.inmetro.gov.br/legislacao/rtac/pdf/RTAC001788.pdf>. Acesso em 18/11/2014.

IPCC. Climate Change 2007: Mitigation of Climate Change. B. Metz, O.R. Davidson, P.R. Bosch, R. Dave, L.A. Meyer (editores). IPCC, 2007.

IPCC. Renewable Energy Sources and Climate Change Mitigation. Special Report of the Intergovernmental Panel on Climate Change. IPCC, 2012.

IPCC. Climate Change 2013: The Physical Science Basis. Contribution of Working Group I to the Fifth Assessment Report of the Intergovernmental Panel on Climate Change. Cambridge: Cambridge University Press, 2013. 1535 p.

JUDKOFF, RON. Energy efficient buildings. In: Fundamentals of materials for energy and environmental sustainability. David S. Ginley, David Cahen (editors). Part 5 Energy efficiency. Cap. 36, p. 491-508. Cambridge: University Press. 2012. 
KOKUBUN, Y. E. O processo de produção de um sistema construtivo em painéis estruturais pré-fabricados em madeira. Dissertação (Mestrado em Tecnologia da Arquitetura) - Faculdade de Arquitetura e Urbanismo, Universidade de São Paulo. São Paulo: USP, 2014. 171 p.

KONZEN, G. Difusão de sistemas fotovoltaicos residenciais conectados à rede no Brasil: uma simulação via modelo de Bass. Dissertação (Mestrado em Ciências) Programa de Pós-Graduação em Energia - Instituto de Energia e Ambiente da Universidade de São Paulo. São Paulo, 2014. 108 p.

KONZEN, G.; ZILLES, R. Difusão de sistemas fotovoltaicos residenciais conectados à rede no Brasil: uma simulação via Modelo de Bass. In: Congresso Brasileiro de Planejamento Energético, 9., 2014, Florianópolis. Anais IX CBPE, Florianópolis: SBPE, 2014.

KÓS, J. R.; ANTONIO, F. Ekó House: Universidade Federal de Santa Catarina, Universidade de São Paulo. In: Sergio Vega Sánchez; Javier Serra María Tomé (Org.). Solar Decathlon Europe 2012: Improving Energy Efficient Buildings. 1ed. Madrid: Imprenta Kadmos, 2013. p. 189-198.

LAMBERTS, R., et al. Casa eficiente: Bioclimatologia e desempenho térmico. Florianópolis: Florianópolis: UFSC/LabEEE, 2010.

LAMBERTS, R. Eficiencia energética na arquitetura. Roberto Lamberts, Luciano Dutra / Fernando Oscar Ruttkay Pereira. Rio de Janeiro: Eletrobrás/Procel, 2014.

LIMA, M. A. S. Armazenamento de energia térmica em componentes de edifícios sobre os quais incide a radiação solar directa. Dessertação (Mestrado em Engenharia Térmica) - Faculdade de Engenharia, Universidade do Porto, Porto, 1995.

LOMARDO, L. L. B. Eficiência Energética nos Edifícios e Sustentabilidade no Ambiente Construído. Eficiência Energética em Edificações, PROCEL Edifica. Rio de Janeiro: PROCEL, 2011.

MCTI. Fatores de Emissão de $\mathrm{CO}_{2}$ pela geração de energia elétrica no Sistema Interligado Nacional do Brasil. Ministério da Ciência, Tecnologia e Inovação - MCTI, 2014a. Disponível em: <http://www.mct.gov.br/index.php/content/view/72764.html>. Acesso em: 05/02/2014.

MCTI. Fatores de Emissão de CO2 de acordo com a ferramenta metodológica: Tool to calculate the emission factor for an electricity system, versions 1, 1.1, 2, 2.1 .0 and 2.2.0" aprovada pelo Conselho Executivo do MDL. Ministério da Ciência, Tecnologia e 
Inovação - $\quad$ MCTI, 2014b. Disponível em: <http://www.mct.gov.br/index.php/content/view/74689.html>. Acesso em: 20/05/2014.

METZ, B.; DAVIDSON, O. R.; BOSH, P. R.; DAVE, R.; MAYER, L. A. (editors). Climate Change 2007: Mitigation. Contribution of Working Group III to the Fourth Assessment Report of the Intergovernmental Panel on Climate Change. Intergovernmental Panel on Climate Change - IPCC. Cambridge: Cambridge University Press, 2007.

MEYERS, R. J., WILLIAMS, E. D., MATTHEWS, H. S. Scoping the potential of monitoring and control technologies to reduce energy use in homes. Energy and Buildings 42. Elsevier, 2010. p. 563-569

MICHAELOWA, A. et al. Understanding CDM methodologies: a guidebook to CDM rules and procedures. Department for Environment, Food and Rural Affairs, Her Magesty's Government, UK. CROWN, 2007.

MIYAZATO, Tarsila. Integração do Sistema de Aquecimento Solar (SAS) ao projeto de edificações residenciais. 2012. Dissertação (Mestrado em Tecnologia da Arquitetura) - Faculdade de Arquitetura e Urbanismo, Universidade de São Paulo. São Paulo: USP, 2012. Disponível em: <http://www.teses.usp.br/teses/disponiveis/16/16132/tde-30052012-141504/>. Acesso em: 21/04/2014.

MONTENEGRO, A. Avaliação do retorno do investimento em sistemas fotovoltaicos integrados a residências unifamiliares urbanas no Brasil. Dissertação (mestrado) - Universidade Federal de Santa Catarina, Centro Tecnológico. Programa de Pós-Graduação em Engenharia Civil. Florianópolis: UFSC, 2013. 175 p.

NOAA. State of the Climate: Global Analysis for December 2014. National Climatic Data Center. 2015.2 Disponível em: <http://www.ncdc.noaa.gov/sotc/global/2014/12>. Acesso em: 24/01/2015)

OECD. OECD economic surveys: Brazil. Organization for Economic Co-Operation and Development. Paris: OECD, 2011.

OLGYAY, V. Arquitectura y clima: Manual de diseño bioclimático para arquitectos y urbanistas. Barcelona: Gustavo Gili, 1998. 203 p.

OLIVEIRA, C. T. A. Relatório final de projeto. Convênio Eletrobrás | USP | FUSP ECV 308/2009 - ECV 308-A/2011. São Paulo: USP, 2013. 39 p. 
ONS. Boletim de Carga Especial de 07/02/2014. Operador Nacional do sistema Elétrico. ONS, 2014.

ONS. Informativo preliminar diário da operação do dia 22/01/2015. Operador Nacional do Sistema Elétrico. ONS, 2015.

ONS. O que é o SIN - Sistema Interligado Nacional. Operador Nacional do Sistema Elétrico. ONS, 2013. Disponível em: http://www.ons.org.br/conheca_sistema/o_que_e_sin.aspx. Acesso em: 20/03/2013.

PACHECO, M. T. G.; GHISI, E.; LAMBERTS, R. Proposição de estratégias para obtenção de Edifícios de Energia Zero. Florianópolis: CB3E, 2013.

PACHECO, M., LAMBERTS, R. Assessment of technical and economical viability for large-scale conversion of single family residential buildings into zero energy buildings in Brazil: Climatic and cultural considerations. Energy Policy, v. 63, p. 716725, 2013.

PBMC. Contribuição do Grupo de Trabalho 1 ao Primeiro Relatório de Avaliação Nacional do Painel Brasileiro de Mudanças Climáticas. Sumário Executivo GT1. Rio de Janeiro: PBMC, 2013. 24 p.

PENG, J.; LU, L.; YANG, H. Review on lifecycle assessment of energy payback and greenhous egas emission of solar photovoltaic systems. Renewable and Sustainable Energy Reviews 19 (2013) 255-274. Elsevier, 2013.

PEREIRA, E. B. et al. Atlas brasileiro de energia solar. São José dos Campos: INPE, 2006. il. 60p.

PROCEL. Eficiência energética em edificações e equipamentos eletromecânicos. Programa Nacional de Conservação de Energia Elétrica. Rio de Janeiro: PROCEL, 2011.

PROCEL. Pesquisa de posse de equipamentos e hábitos de usos: Setor residencial. Programa Nacional de Conservação de Energia Elétrica. Rio de Janeiro: PROCEL, 2007.

PROCOBRE. Qualidade em instalação de aquecimento solar: boas práticas. Instituto Brasileiro do Cobre. São Paulo: PROCOBRE, 2009. 
PROJETO EKÓ HOUSE. Project Manual. São Paulo: Team Brasil, 2012.

RAIMO, P. A. Aquecimento de água no setor residencial. 2007. 125 f. Dissertação (Mestrado) - Programa Interunidades de Pós Graduiação em Energia da Universidade de São Paulo (Escola Politécnica /Faculdade de Eonomia e Administração / Instituto de Eletrotécnica e Energia / Instituto de Física), São Paulo, 2007.

ROGNER, H.-H., et al. In Climate Change 2007: Mitigation - Introduction. Contribution of Working Group III to the Fourth Assessment Report of the Intergovernmental Panel on Climate Change. Cambridge: Cambridge University Press, 2007.

ROAF, S et al. Ecohouse: a design guide. Manuel Fuentes e Stephanie Thomas. Arquitectural Press, 2007.

RÜTHER, R. Edifícios solares fotovoltaicos: o potencial da geração solar fotovoltaica integrada a edificações urbanas e interligadas à rede elétrica pública no Brasil. Florianópolis: LABSOLAR, 2004. 114 p.: il.

SÁNCHEZ, S. V. Solar Decathlon Europe 2010: Towards energy efficient buildings. Madri: 10ACTION, 2011.

SANTOS, A. C. N. Estudo da eficiência energética de um sistema de arrefecimento com materiais de mudança de fase. 2013. 103 f. Dissertação (Mestrado Integrado em Engenharia Mecânica) - Faculdade de Engenharia da Universidade do Porto. Porto. 2013.

SCOGNAMIGLIO, A., RØSTVIK, H. N. Photovoltaics and nearly zero energy buildings: new opportunity and challenge for architecture. 26th European Photovoltaic Solar Energy Conference and Exhibition Proceedings, 2012. P. 3848 - 3858.

SCRIPPS INSTITUTION OF OCEANOGRAPHY. Graphics Gallery, Scripps $\mathrm{CO}_{2}$ Program, $2014 . \quad$ Disponível em: <http://scrippsco2.ucsd.edu/graphics_gallery/graphics_gallery.html>. Acesso em: 30/12/2014.

SDE. Solar Decathlon Europe 2012: Rules v. 5.0. Madri: SDE, 2012.

SDE. Solar Decathlon Europe 2012: Monitoring. Madro: SDE, 2014. Disponível em: < monitoring.sdeurope.org>. Acesso em 12/11/2014.

SERRA, R. Arquitectura y climas. Barcelona: Gustavo Gili, 1999. 
SOUBBOTINA, T. P. Beyond economic growth: an introduction to sustainable development. 2 ed. The International Bank for Reconstruction and Development The World Bank. Washington: THE WORLD BANK, 2004.

SUPSI. II fotovoltaico negli edifici: Informazioni e costi. Scuola Universitaria Professionale della Svizzera Italiana. SUPSI, 2014a. Disponível em: $<$ http://www.bipv.ch/images/materiale/linee_guida/isaac_il_fotovoltaico_negli_edifici/Fly er_definitivo.pdf>. Acesso em: 10/04/2014.

SUPSI. Multifunctionality of BiPV. Scuola Universitaria Professionale della Svizzera Italiana. SUPSI, 2014b. Disponível em: < http://www.bipv.ch/index.php/en/products-entop/multifunctionality-of-bipv>. Acesso em: 10/04/2014.

STERN, P., DIETZ, T. The value basis of environmental concern. Journal of Social Issues 50 (3), 2004. p. 65-84

STIRLINGLED. LED light comparison. STIRLINGLED, 2014. Disponível em: < http://www.stirlingled.com/pdfs/LED_Bulb_Comparison.pdf>. Acesso em 17/04/2014.

TORCELLINI, S. P.; DERU, M. CRAWLEY, D. Zero energy buildings: a critical look at the definition. National renewable energy laboratory - NREL. Aceee Summer Study Pacific Grove. Proceedings. Califórnia, August 14-18, 2006. 15p. Disponível em: <http://www.nrel.gov/docs/fy06osti/39833.pdf>. Acesso em: 05/08/2012.

UNEP. Buildings and climate change: Status, challenges and opportunities. United Nations Environment Programme. UNEP, 2007. Disponível em: $<$ http://www.unep.org/sbci/pdfs/BuildingsandClimateChange.pdf>. Acesso em $15 / 08 / 2012$.

UNEP. Towards a Green Economy: Pathways to Sustainable Development and Poverty Eradication. United Nations Environment Programme. UNEP, 2011.

UNFCCC. Clean Development Mechanism Methodology Booklet. 212p. Bonn: Climate Change Secretariat (UNFCCC), 2010. Disponível em: $<$ http://cdm.unfccc.int/methodologies/documentation/meth_booklet.pdf\#1.2>. Acesso em 02/08/2011.

UNFCCC. Conference of the Parties serving as the meeting of the Parties to the Kyoto Protocol on its first session. Montreal, 28 November to 10 December 2005. Report, 2006. Disponível em: <http://unfccc.int/resource/docs/2005/cmp1/eng/08a01.pdf\#page=6>. Acesso em 
06/08/2011.

UNFCCC. Full text of the convention. United Nations Framework Convention on Climate Change. $\quad 2014.2$ Disponível em: <http://unfccc.int/essential_background/convention/background/items/2536.php>. Acesso em: 30/12/2014.

UNFCCC. Methodological tool: Tool to calculate the emission factor for an electricity system. Tool 07, Version 04.0, Clean Development Mecanism. United Nations Framework Convention on Climate Change. 2013. Disponível em: < http://cdm.unfccc.int/methodologies/PAmethodologies/tools/am-tool-07-v4.0.pdf>. Acesso em 05/04/2014.

UNITED NATIONS. Kyoto protocol to the United Nations framework convention on climate change. $\quad 1998 . \quad$ Disponível em: < http://www.mct.gov.br/upd_blob/0012/12425.pdf>. Acesso em 02/08/2011.

UNITED NATIONS. World Urbanization Prospects: The 2014 Revision, Highlights. Department of Economic and Social Affairs, Population Division. Nova lorque: United Nations, 2014.

VAN LENGEN, J. Arquitetura dos índios da Amazônia. São Paulo: B4 Ed., 2013. 132 p. : il.

VITTORINO, F.; SATO, N. M. N.; AKUTSU, M. Desempenho térmico de isolantes refletivos e barreiras radiantes aplicadas em coberturas. In: VII Encontro Nacional sobre Conforto no Ambiente Construído e III Conferência Latino-Americana sobre Conforto e Desempenho Energético de Edificações, 2003, Curitiba, PR. ENCACCOTEDI, 2003, Curitiba. Curitiba: Anais III ENCAC, 2003. v. CD. p. 1277-1284.

WCED. Our Common Future. World Commission on Environment and Development. Oxford: Oxford University Press, 1987.

WEIMER, G. Arquitetura popular brasileira. São Paulo: Martins Fontes, 2005. 333 p. WILD-SCHOLTEN, M. J. Energy payback time and carbon footprint of commercial photovoltaic systems. In: Solar Energy Materials \& Solar Cells 119. Elsevier, 2014. p. 296-305. 
WOOD, G., NEWBOROUGH, M. Energy-use information transfer for intelligent homes: enabling energy conservation with central and local displays. In: Energy and Buildings 39. Elsevier, 2007. p. 495-503

YUE, D., YOU, F., DARLING, S. B. Domestic and overseas manufacturing scenarios of silicon-based photovoltaics: Life cycle and environmental comparative analysis. In: Solar Energy n. 105. Elsevier, 2014. p. 669-678.

ZILLES, R. et al. Sistemas fotovoltaicos conectados à rede elétrica. Oficina de Textos: São Paulo, 2012. 


\section{APÊNDICE A}

O Solar Decathlon Europe é a edição europeia da competição Solar Decathlon ${ }^{96}$, que acontece nos Estados Unidos desde 2002, em edições bianuais, e é organizada pelo Departamento de Energia do Estados Unidos (US Department of Energy - DOE). A edição europeia foi viabilizada por meio de uma parceria entre o DOE, o Governo da Espanha, e a Universidade Politécnica de Madri (UPM), sendo que as duas primeiras edições aconteceram em Madri, nos anos de 2010 e 2012. Esta competição desafia equipes universitária a projetar, construir e operar casas desenvolvidas visando à redução do consumo de energia e à obtenção de toda energia necessária para sua operação por meio da fonte solar, considerando o balanço energético anual.

A competição tem por objetivo desenvolver habilidades de trabalho em equipes multidisciplinares, com foco no desenvolvimento de soluções inovadoras para edificações. O público geral pode perceber as reais possibilidades de se reduzir impactos ambientais, mantendo níveis de conforto e a qualidade no projeto de unidades habitacionais. Além disso, universidades, empresas e instituições públicas tem acesso a uma nova forma de colaboração, que possibilita o melhoramento ou mesmo usos diferentes e criativos de produtos existentes no mercado (SDE, 2012).

Os protótipos participantes são avaliados com base em 10 provas. Para as provas objetivas as avaliações são feitas por júris técnicos, por meio de medições realizadas durante a competição, e também com base em simulações realizadas pelas equipes considerando a operação do protótipo durante um ano. As avaliações referentes a provas subjetivas são feitas por um corpo de jurados especialistas em cada área. As provas estratégicas, de Inovação de Sustentabilidade, são avaliadas de forma transversal, considerando a presença desses quesitos nas demais provas da competição. O diagrama na Figura A1 relaciona as diferentes provas do SDE.

\footnotetext{
${ }^{96}$ www.solardecathlon.org
} 


\begin{tabular}{|c|c|c|}
\hline \multicolumn{2}{|r|}{ Provas } & $\begin{array}{l}\text { Classificação } \\
\text { Ekó House }\end{array}$ \\
\hline \multirow{2}{*}{ Arquitetura } & 1. Arquitetura & $12^{\circ}$ \\
\hline & 2. Engenharia e construção & $14^{\circ}$ \\
\hline \multirow{2}{*}{ Energia } & 3. Eficiência energética & $10^{\circ}$ \\
\hline & 4. Balanço de energia elétrica & $15^{\circ}$ \\
\hline \multirow{2}{*}{ Conforto } & 5. Condições de conforto & $5^{\circ}$ \\
\hline & 6. Funcionamento ds casa & $16^{\circ}$ \\
\hline \multirow{2}{*}{ Socioeconômico } & 7. Comunicação e sensibilização social & $5^{\circ}$ \\
\hline & 8. Industrialização e viabilidade de mercado & $12^{\circ}$ \\
\hline \multirow{2}{*}{ Estratégico } & 9. Inovação & $15^{\circ}$ \\
\hline & 10. Sustentabilidade & $3^{\circ}$ \\
\hline
\end{tabular}

Figura A1: Provas da competição SDE 2012 e classificação do protótipo Ekó House. Fonte: Adaptado de SDE, 2012; KOKUBUN, 2014.

$\mathrm{Na}$ edição de 2012 a competição SDE reuniu 18 equipes, oriundas de 10 diferentes países. O protótipo Ekó House obteve a premiação de terceiro lugar na prova de Sustentabilidade. Este reconhecimento e destaque alcançados pelo protótipo brasileiro reforçam a justificativa de se adotar, nesta dissertação, o projeto Ekó House como um exemplo prático de aplicação das premissas e estratégias para uma Casa Solar em uma unidade habitacional orientada ao desenvolvimento sustentável. A fotografia na Figura A2 ilustra a Vila Solar, com todos os protótipos participantes da competição SDE 2012.

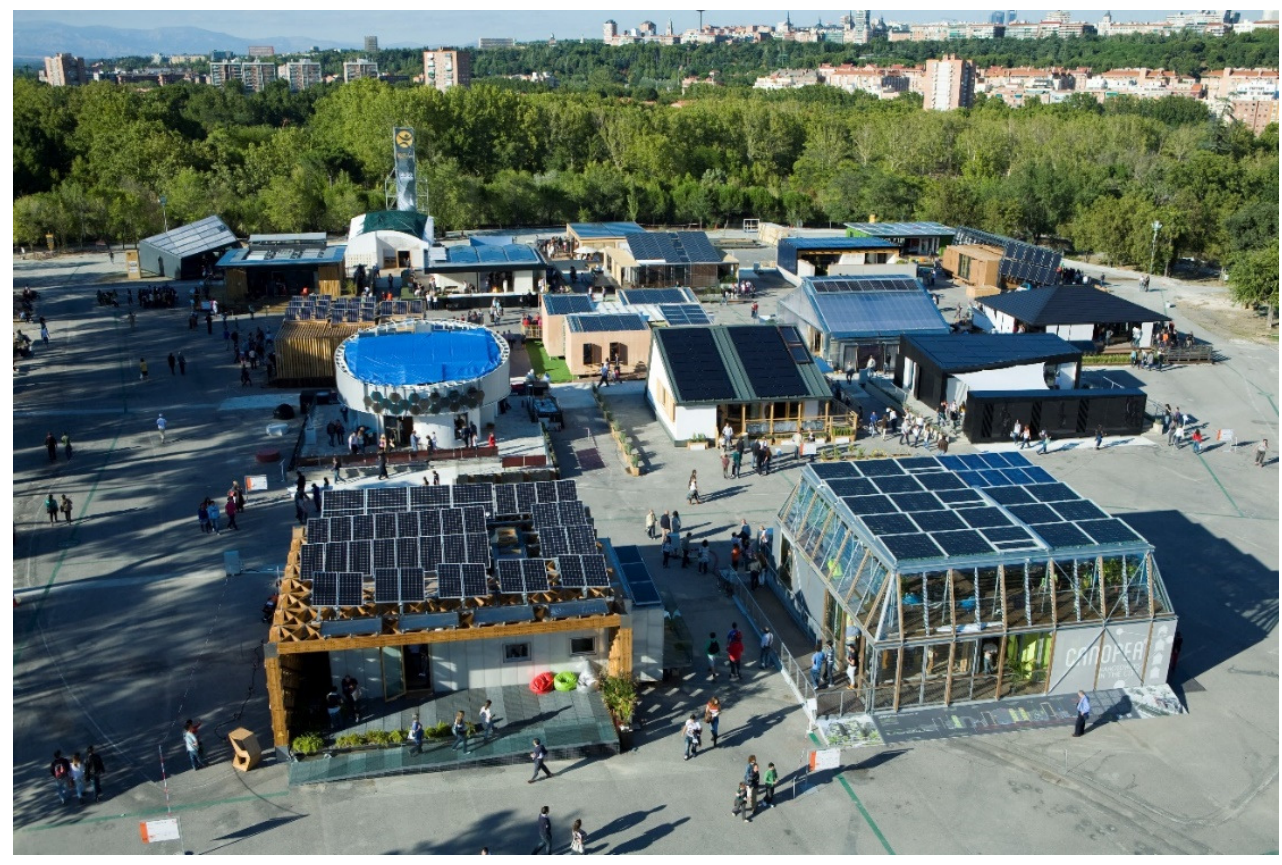

Figura A2: Competição Solar Decathlon Europe 2012, realizada em Madri, Espanha. Fonte: I+D+Art/SDE 2012. 


\section{APÊNDICE B}

Este apêndice apresenta as propriedades dos materiais e elementos construtivos que fundamentam as discussões sobre as estratégias passivas de condicionamento térmico das edificações.

Os elementos de fechamento da edificação podem ser opacos, translúcidos ou transparentes à radiação solar. Estes elementos podem ser aplicados de modo a controlar os ganhos de calor. A Figura A1 ilustra como ocorrem as trocas térmicas em superfícies opacas, translúcidas e transparentes, quando expostas à radiação solar.
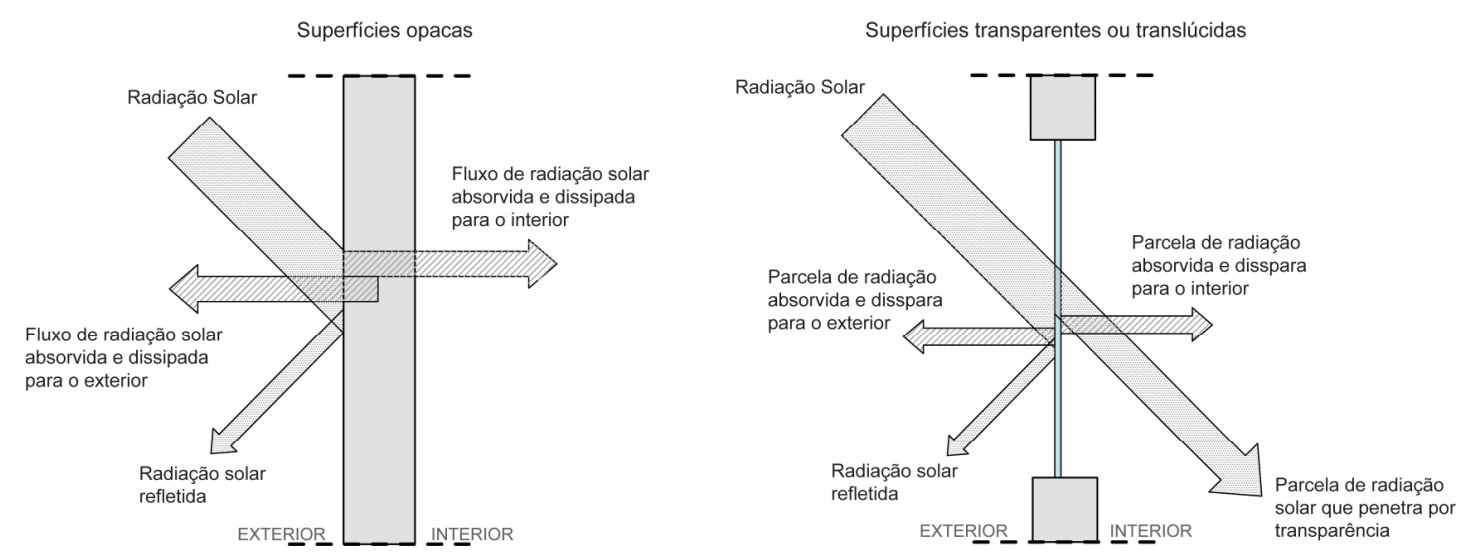

Figura B1: Trocas de calor através de superfícies opacas (à esquerda) e através de superfícies translúcidas e transparentes (à direita).

Fonte: Adaptado de FROTA, 2003.

Nos fechamentos opacos a troca de calor ocorre por condução e convecção quando há diferença entre a temperatura das superfícies interna e externa destes fechamentos. Nos vidros e demais fechamentos translúcidos ou transparentes, as trocas térmicas por condução e convecção ocorrem de forma semelhante a essas trocas em fechamentos opacos. No entanto, a radiação é o principal processo nas trocas térmicas dos vidros e a parcela de radiação transmitida diretamente ao interior depende da transmissividade ( $\tau)$ do vidro (FROTA; SCHIFFER, 2003; LAMBERTS et al., 2014). 
Essas trocas de calor se devem às propriedades de refletividade $(\rho)$, absortividade ${ }^{97}(\alpha)$, transmissividade $(\tau)^{98}$ e emissividade $(\varepsilon)$ dos materiais, bem como suas características de isolamento e inércia térmica influem nas trocas térmicas associadas à radiação. $A$ soma dos valores de $\rho$, a e $\tau$ é sempre igual a 1,0 (LAMBERTS et al., 2014).

A absortância é o quociente da taxa de radiação solar absorvida por uma superfície pela taxa de radiação solar incidente sobre esta mesma superfície (ABNT NBR 152201:2005). Esta propriedade da superfície depende do calor, acabamento e tipo do material. Sendo assim, superfícies contendo materiais com acabamentos em cores escuras são mais favoráveis para absorver quantidade de radiação do que os claros e refletivos (BROWN; DEKAY, 2004).

A emissividade é o quociente da taxa de radiação emitida por um corpo uma propriedade associada à parcela de radiação que é absorvida por um material e emitida ao ambiente interno, ou seja, caracteriza a capacidade de um material aquecido emitir radiação infravermelha de onda longa em uma determinada temperatura. Trata-se de uma propriedade da camada superficial do material emissor. Vittorino; Sato; Akutsu (2003, p. 1287) apontam que uma forma de reduzir ganhos de calor pela cobertura de edificações pressupõe o uso de materiais de alta refletividade e baixa emissividade para diminuir, respectivamente, a absorção de energia solar e a quantidade de energia térmica de onda longa irradiada para o interior.

A refletância à radiação solar é o quociente da taxa de radiação solar refletida por uma superfície pela taxa de radiação solar incidente sobre esta mesma superfície (ABNT NBR 15220-1:2005). Materiais condutores de eletricidade, que é o caso de superfícies metálicas, refletem grande parte da energia sobre eles incidentes devido à grande quantidade de eletros livres presentes, resultando em uma pequena quantidade de radiação absorvida e baixa emissão de energia térmica (VITTORINO; SATO; AKUTSU, 2003). A Tabela A1 elenca os valores de emissividade e absortividade de alguns materiais.

\footnotetext{
97 Também denominada absortância por alguns autores, mas convém esclarecer que, via de regra, "[...] o termo "absortividade" representa a quantidade de energia radiante absorvida do total que incide sobre um determinado material ou substância, e depende de sua composição química. Já o termo "absortância" é definido como a quantidade de energia radiante que atinge uma superfície e que é absorvida por ela. A absortância de uma superfície será função da absortividade do material que compõe a sua camada superficial exposta à radiação e de outras características da superfície, como a rugosidade, ondulação" (DORNELLES, 2008, p.35)

${ }^{98}$ Por se tratar de uma característica dos materiais translúcidos, esta propriedade dos materiais é abordada no item 3.5.1.3.
} 


\begin{tabular}{lcc}
\hline \multicolumn{1}{c}{ Tipo de superfície } & $\boldsymbol{\alpha}$ & $\boldsymbol{\varepsilon}$ \\
\hline Chapa de alumínio (nova) & 0,05 & 0,05 \\
\hline Chapa de alumínio (oxidada) & 0,15 & 0,15 \\
\hline Chapa de aço galvanizada (nova) & 0,25 & 0,25 \\
\hline Concreto aparente & $0,68 / 0,80$ & $0,85 / 0,95$ \\
\hline Telha de barro & $0,75 / 0,80$ & $0,85 / 0,95$ \\
\hline Reboco claro & $0,30 / 0,50$ & $0,85 / 0,95$ \\
\hline Vidro comum & Transparente & $0,90 / 0,95$ \\
\hline Pintura branca & 0,20 & 0,90 \\
\hline Pintura verde claro & 0,40 & 0,90 \\
\hline Pintura preta & 0,97 & 0,90 \\
\hline
\end{tabular}

Tabela B1: Absortividade e emissividade de materiais e cores de pinturas.

Fonte: FROTA; SCHIFFER, 2003; LAMBERTS et al., 2014

A condutividade térmica $(\lambda)$ é a propriedade associada à capacidade de um determinado material em conduzir maior ou menor quantidade de calor por unidade de tempo (LAMBERTS et al., 2014). A condutividade depende da densidade do material, pois a matéria é melhor condutora do que o ar contido em seus poros; da natureza química do material, pois os materiais amorfos são normalmente menos condutores do que os materiais cristalinos; e do teor de umidade do material, devido ao fato de que a água é melhor condutora do que o ar (FROTA, SCHIFFER, 2003).

Já a resistência térmica $(R)$ é o inverso da condutividade térmica (ROAF, 2007), sendo a capacidade de um material resistir à passagem do calor. Quanto maior a espessura e menor a condutividade térmica, maior será a resistência térmica de um material. $A$ resistência térmica de um componente construtivo é a soma das resistências de todos os materiais que o compõe e das resistências térmicas superficiais interna e externa, devendo ser ainda acrescida a resistência de camadas de ar, quando presentes em sistemas como, por exemplo, paredes duplas intercaladas por câmaras de ar (LAMBERTS et al., 2014).

A transmitância térmica $(U)$ está associada à capacidade de um material em transmitir a radiação solar para o ambiente interno por unidade de área de uma dada estrutura ou componente construtivo, e dividida pela diferença entre a temperatura ambiente de cada um dos lados desta estrutura (ROAF, 2007).

A capacidade térmica (ou calorífica) de um material está associada à sua capacidade de reter calor. Esta capacidade é expressa do calor específico, fator mensurado pela quantidade de calor necessária para fazer elevar de uma unidade de temperatura, a sua unidade de massa (FROTA, SCHIFFER, 2003). Sendo assim, por meio do valor da capacidade térmica de um material, é possível avaliar seu potencial de contribuição em termos de inércia térmica para um ambiente. 


\section{APÊNDICE C}

Este apêndice apresenta uma análise das estratégias bioclimáticas indicadas para a cidade São Paulo por meio da ferramenta Climate Consultant 5.5. São apresentadas as estratégias na carta bioclimática, de modo a visualizar mais claramente a relação entre cada estratégia e as condições climáticas. São também descritos os critérios utilizados na definição de cada estratégia, conforme tutorial da ferramenta Climate Consultant 5.5.

Na Figura B1, no gráfico à esquerda, está demarcada a Zona de Conforto para a cidade de São Paulo, que inclui as horas do ano em que as condições climáticas são confortáveis, dentro dos parâmetros estabelecidos. Os pontos em vermelho, e que aparecem fora da Zona de Conforto, indicam as horas do ano em que se faz necessário adotar estratégias de projeto para poder obter conforto nas edificações.

O gráfico da direita na Figura B1 demonstra em que condições climáticas a estratégia de sombreamento em janelas passa a ser apropriada para evitar ganhos solares diretos no interior de edificações. Esta estratégia é definida com base em um valor de temperatura exterior (geralmente o limite inferior de temperatura da faixa de conforto estabelecida) e um valor mínimo de radiação horizontal, a partir dos quais todas as aberturas deveriam ser sombreadas. Nota-se que a Carta Psicrométrica ${ }^{99}$ mostra o número de horas nas quais o sombreamento de janelas deve ser adotado, mas essas horas não são adicionados ao número total de horas confortáveis porque, de acordo com os parâmetros da ferramenta Climate Consultant 5.5, o sombreamento por si só não garante o conforto no ambiente interno.

99 Carta Psicrométrica é uma denominação alternativa à Carta Bioclimática apresentada no Capítulo 3. Neste apêndice foi utilizada a denominação utilizada na ferramenta Climate Consultant 5.5. 

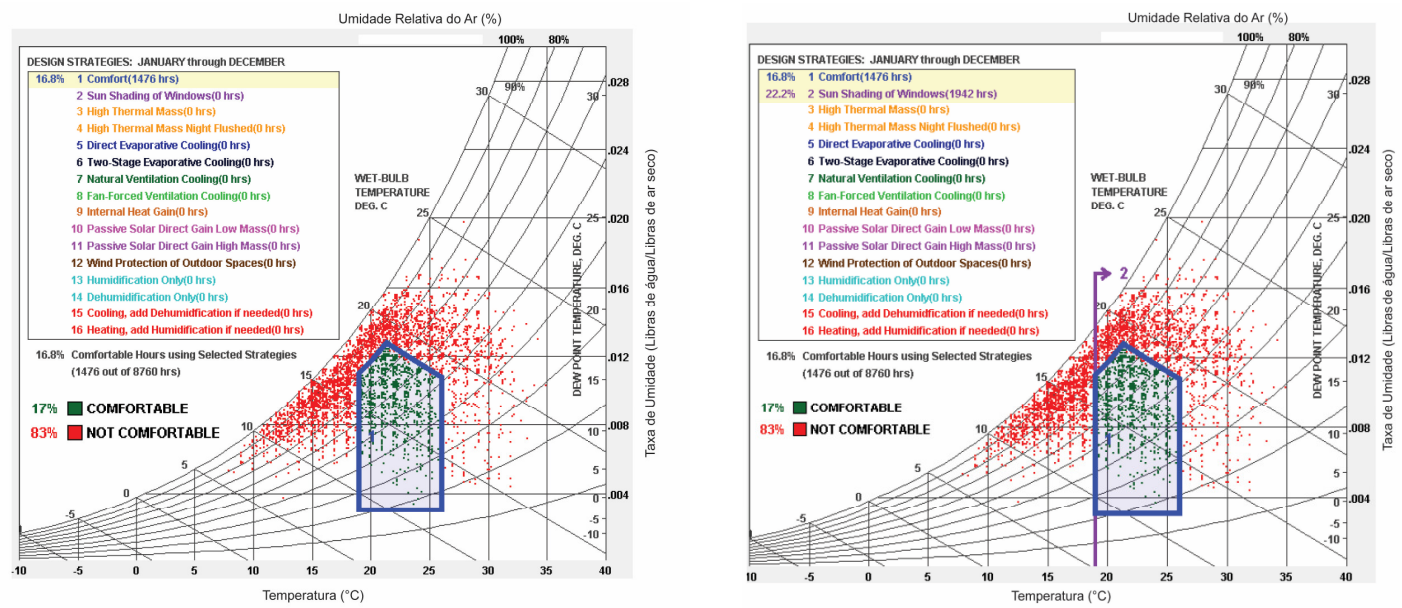

Figura C1: Zona de conforto (esquerda), e estratégia de sombreamento de aberturas (direita). Fonte: Climate Consultant 5.5.

Os gráficos da Figura B2 demonstram as zonas indicadas para o uso de alta massa térmica como estratégia. No verão, em condições de clima quente e seco, o uso de massa térmica no interior é uma estratégia para resfriamento. As propriedades de armazenamento de calor, amortecimento e atraso térmico dos materiais de alta massa térmica evita que o interior sofra as mesmas variações bruscas de temperatura que o exterior. À esta estratégia pode ser associado algum sistema de ventilação noturna, natural ou forçada, para auxiliar que o calor armazenado nos materiais de alta térmica durante o dia seja liberado e dissipado durante a noite.

A zona na qual estas estratégias são apropriadas é definida com base na temperatura superior da faixa de conforto definida, sendo que elas passam a ser apropriadas, em média, a $1^{\circ} \mathrm{C}$ inferior à essa temperatura, estando sempre dispostas à direita da Zona de conforto. As delimitações superior e inferior da zona de alta massa térmica são definidas pelos limites de temperatura de ponto de orvalho (Dew Point Temperature), de modo a evitar a possibilidade de precipitação nas superfícies de alta massa. Dessa forma, a ferramenta Climate Consultant 5.5 verifica automaticamente todas as horas do ano para assegurar que esses critérios sejam atendidos. 

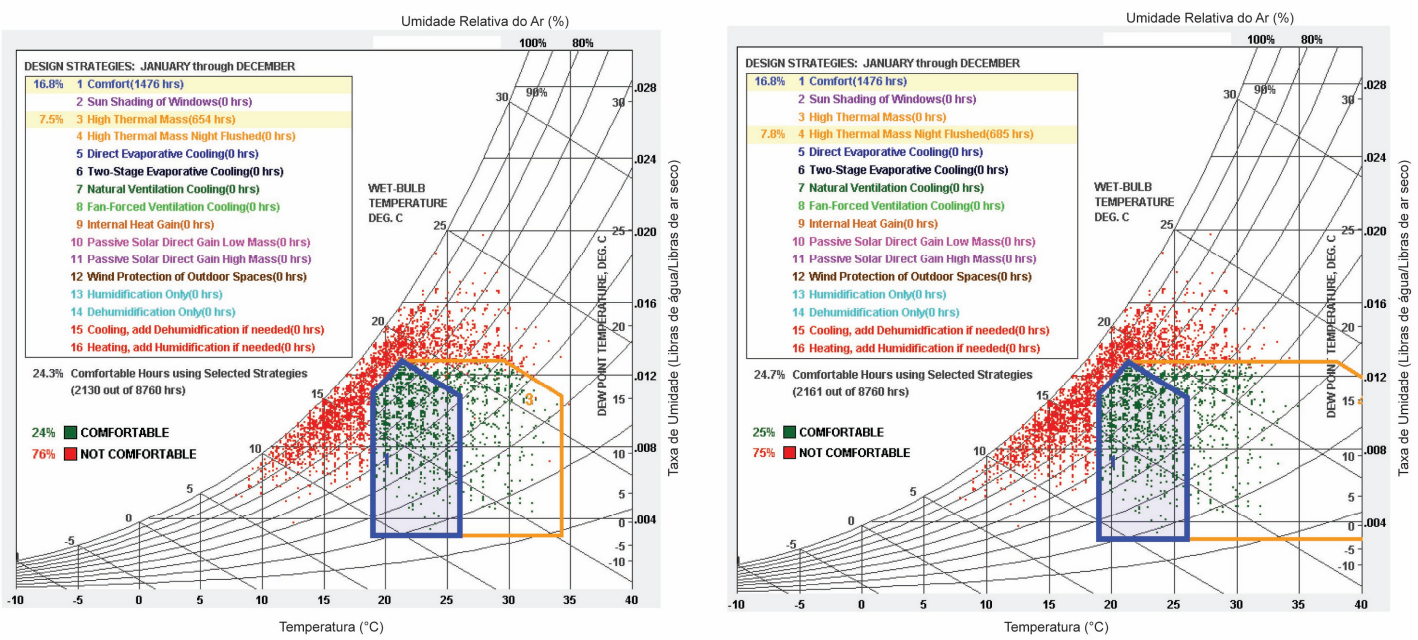

Figura C2: Alta massa térmica (esquerda), e alta massa térmica com ventilação noturna (direita). Fonte: Climate Consultant 5.5.

Os gráficos da Figura B3 indicam, respectivamente, as estratégias de resfriamento evaporativo direto e resfriamento evaporativo em dois estágios. O resfriamento evaporativo é obtido quando a água muda do estado liquido para o gasoso, absorvendo para isso calor latente, e dessa forma o ar fica mais frio e também mais úmido. Estas estratégias são definidas pelas temperaturas mínima e máxima da Zona de Conforto, e são delimitadas por uma zona à direita e abaixo da zona de conforto, onde a umidade é reduzida. No caso do resfriamento evaporativo em dois estágios, o primeiro estágio consiste em utilizar a evaporação para arrefecer o exterior de um trocador de calor, através do qual o ar é aspirado e direcionado para a segunda fase, onde é resfriado por meio de evaporação direta.
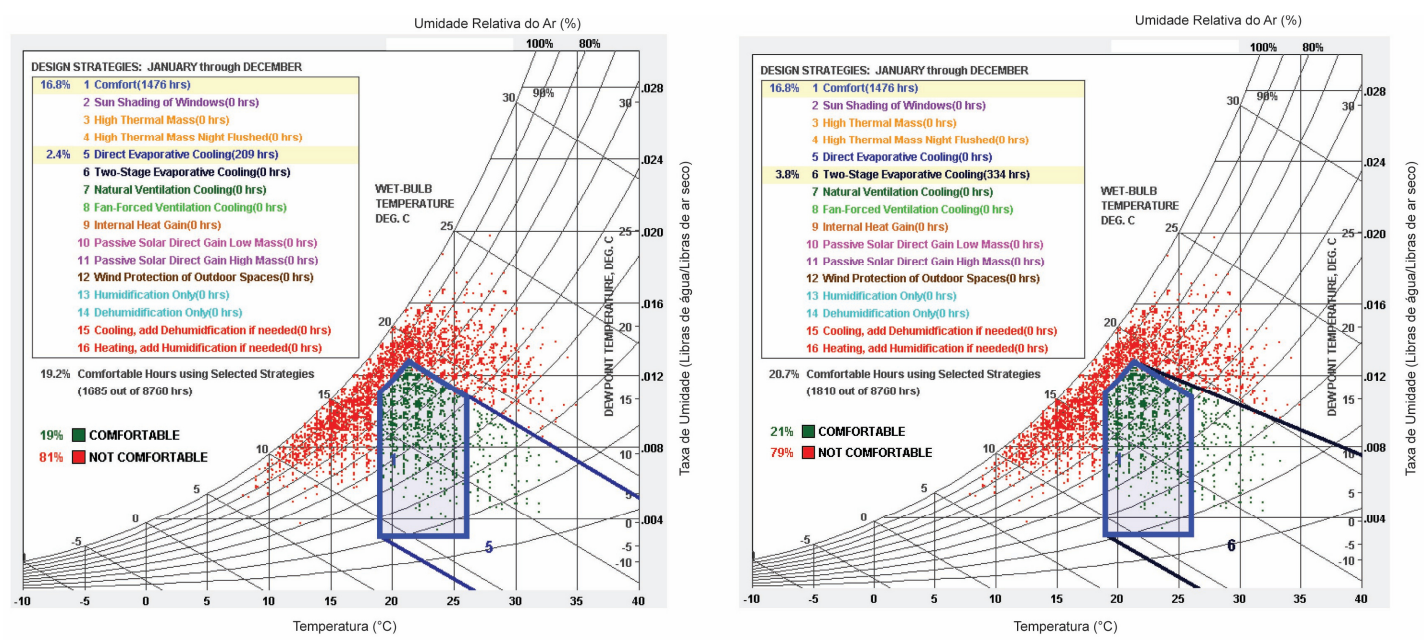

Figura C3: Resfriamento evaporativo direto (esquerda), e resfriamento evaporativo em dois estágios (direita).

Fonte: Climate Consultant 5.5. 
Os gráficos na Figura B4 indicam as zonas nas quais são indicadas a ventilação natural e forçada como estratégia para obtenção de conforto térmico. O resfriamento por ventilação ocorre devido à ação do movimento do ar, que contribui para aumentar a taxa de evaporação do suor do corpo, proporcionando sensação de resfriamento, conforme explicado no Capítulo 3. A ventilação natural é definida como efetiva para uma velocidade mínima do ar de $2 \mathrm{~m} / \mathrm{seg}$. Se a velocidade do ar exterior é inferior a esta velocidade, a ventilação natural deixa de ser considerada como estratégia efetiva para o conforto térmico. É também definida uma faixa de velocidade máxima confortável para a movimentação do ar no interior, entre $0,082 \mathrm{~m} / \mathrm{seg}$ e $1,6 \mathrm{~m} / \mathrm{seg}$, sendo que a sensação de redução de temperatura varia entre $2,5^{\circ} \mathrm{C}$ e $3,7^{\circ} \mathrm{C}$. O limite superior para a zona de ventilação natural é definido pela temperatura e umidade relativa do ar. A ventilação forçada pode ser obtida por meio do uso de ventiladores de parede, teto, ou outros. Os critérios para delimitar a zona de ventilação forçada são os mesmos utilizados para a ventilação natural, portanto a delimitação de ambas as zonas na Carta Psicrométrica é praticamente a mesma, conforme se observa na Figura B4.
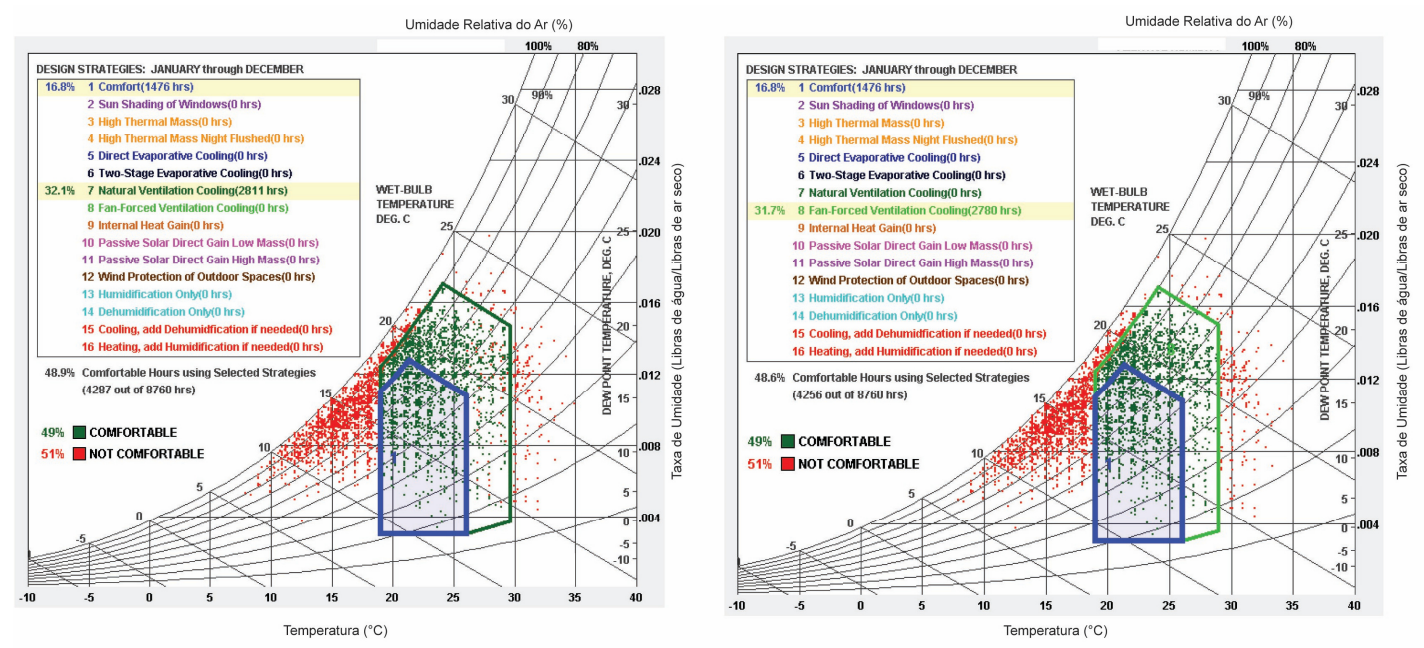

Figura C4: Resfriamento por ventilação natural (esquerda), e resfriamento por ventilação forçada (direita). Fonte: Climate Consultant 5.5.

O gráfico na Figura B5 indica a zona na qual a estratégia de ganhos internos de calor é indicada. Esta estratégia consiste em aproveitar o calor liberado no interior da edificação por lâmpadas, equipamentos ou pela atividade metabólica dos ocupantes. A eficiência no aproveitamento deste calor está atrelada às características do envelope da edificação, sendo que edificações com bom isolamento aproveitam melhor estas cargas térmicas. No caso de edificações residenciais, estas cargas são muitas vezes desprezíveis, sendo necessárias outras estratégias para aquecimento do ambiente interno. 


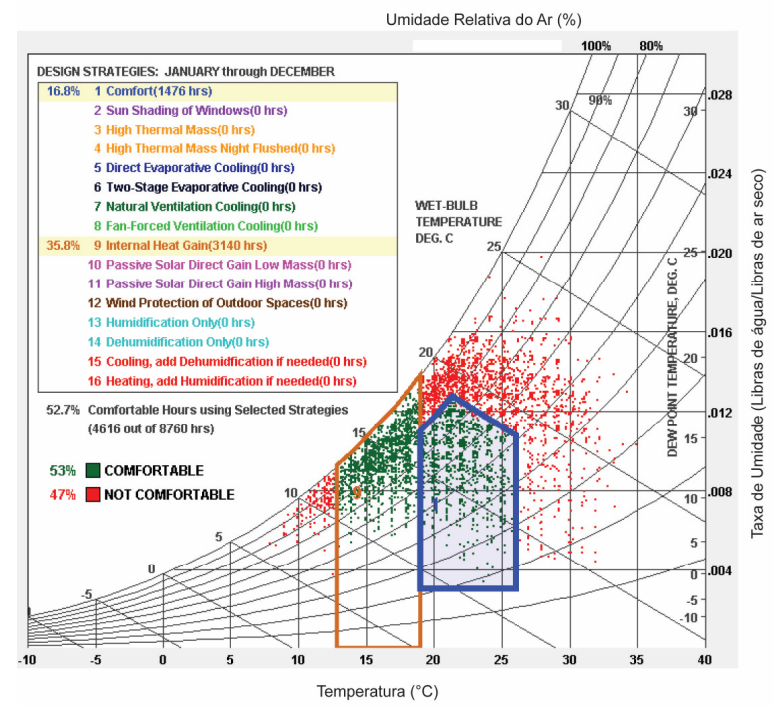

Figura C5: Ganho interno de calor.

Fonte: Climate Consultant 5.5.

O gráfico na Figura B6 indica as zonas das estratégias de ganho solar passivo. A representação na carta psicrométrica é uma linha tracejada, por se tratar de estratégias que são estimadas sem muita precisão pela ferramenta Climate Consultant 5.5, já que dependem em grande parte das soluções adotadas na edificação. Se a edificação possui aberturas com dimensão e orientação apropriada, os ganhos solares passivos podem ser efetivos na contribuição para o aquecimento interno. O Climate Consultant 5.5 assume que elementos de sombreamento bloqueiam o sol sempre que ganhos solares diretos não são necessários.

A zona de ganho solar passivo direto com baixa massa térmica é definida com base na radiação mínima necessária para aumentar a temperatura em $5,6^{\circ} \mathrm{C}$ em uma hora, geralmente $157,5 \mathrm{Wh} / \mathrm{m}^{2}$. Nesta zona o atraso térmico considerado é baixo, cerca de 3 horas o que implica que a radiação seja medida nestes níveis com três horas de antecedência em relação ao horário em que o aquecimento será necessário.

A zona para o ganho solar passivo direto com alta massa térmica é definida com base na radiação mínima necessária para aumentar a temperatura em $5,6^{\circ} \mathrm{C}$ em uma hora, e neste caso a radiação é de cerca de $315 \mathrm{Wh} / \mathrm{m}^{2}$. Com o uso de alta massa térmica, o atraso térmico assumido pela ferramenta é de cerca de 12 horas.

Em ambos os casos, um determinado horário é incluído nestas zonas se o aumento da temperatura interna gerado pela radiação atingir as temperaturas mínimas estabelecidas para a zona de conforto. Na carta bioclimática, os limites inferiores destas zonas são definidos pela temperatura mínima externa na qual a radiação solar disponível poderá gerar as temperaturas mínimas de conforto no interior. 

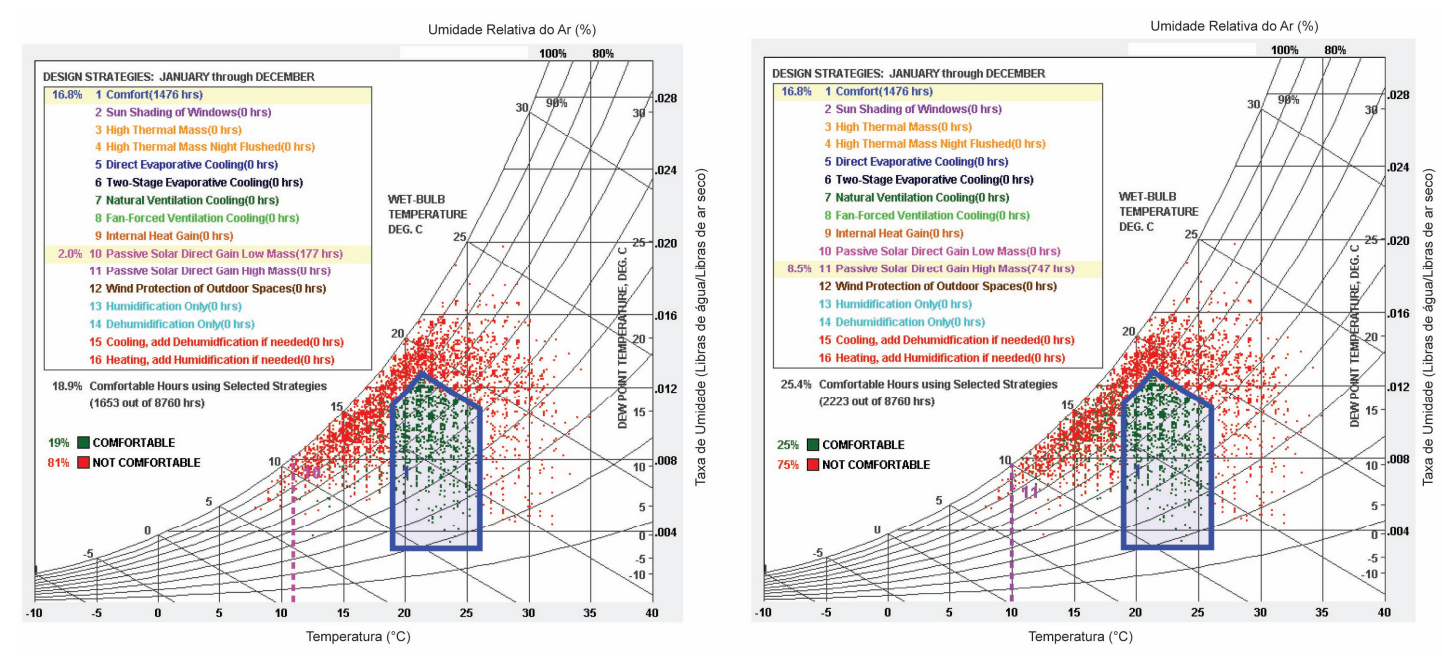

Figura C6: Ganho solar passivo direto com baixa massa térmica (esquerda), ganho solar passivo direto com alta massa térmica (direita).

Fonte: Climate Consultant 5.5.

No gráfico da esquerda da Figura B7 está representada a zona onde é necessária a desumidificação do ar, localizada acima da zona de conforto. Esta zona delimita as horas do ano em que a temperatura está dentro da faixa de conforto estabelecida, mas em que a umidade relativa do ar está acima dos valores limites para o conforto térmico. A desumidificação, neste caso, pode ser assumida por algum equipamento desumidificador, ou pelo aparelho de ar condicionado.

No gráfico da direita na Figura B7 estão indicadas as estratégias de resfriamento e aquecimento. Estas zonas são definidas pelas temperaturas limites da faixa de conforto. À esquerda da zona de conforto encontra-se a zona em que é necessário aquecimento e à direita da zona de conforto estão as horas em que é necessário resfriamento. Nestas estratégias, o resfriamento e aquecimento são obtidos de forma mecânica, por exemplo por aparelhos de ar condicionado, bombas de calor, caldeiras, entre outros. 

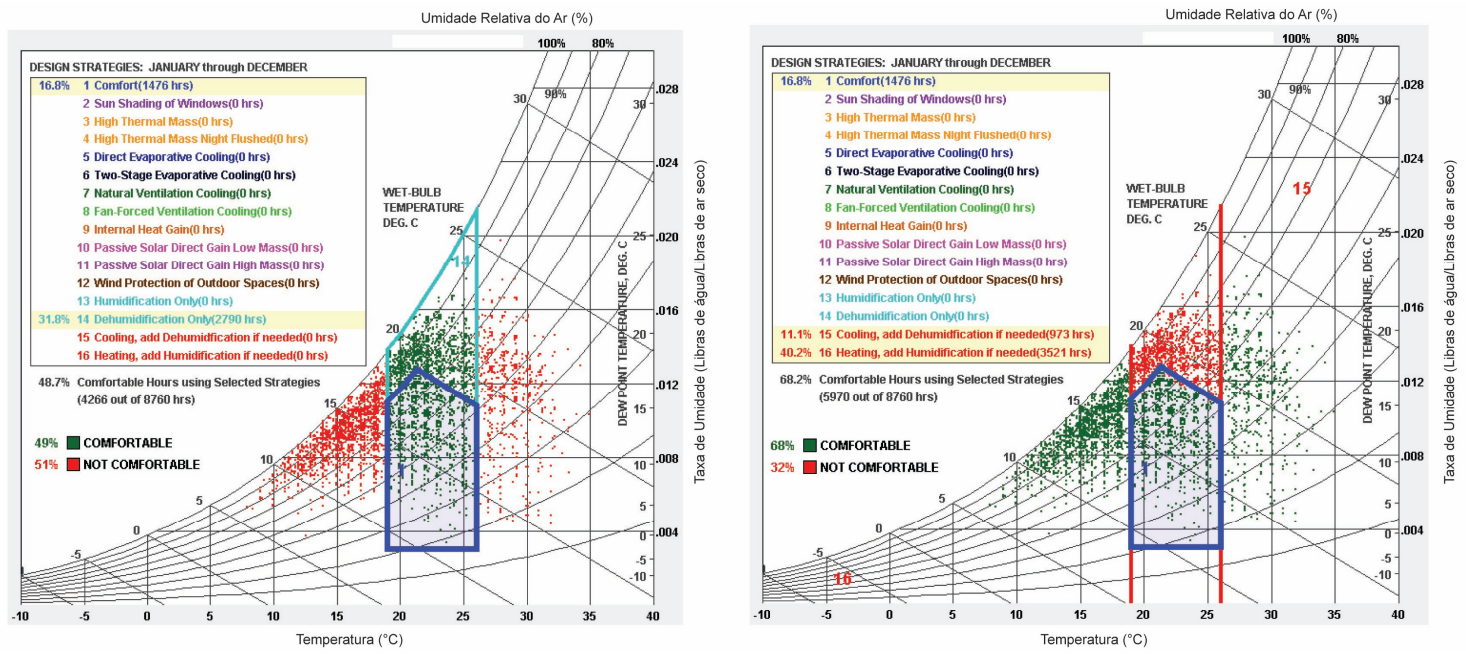

Figura C7: Desumidificação (esquerda) resfriamento e aquecimento (direita). Fonte: Climate Consultant 5.5.

Como forma de ilustrar a interação entre as diferentes estratégias, é possível observar na Figura B8 o quanto se reduz ao longo do ano a necessidade destes sistemas ativos de resfriamento e aquecimento, quando adotadas estratégias passivas.
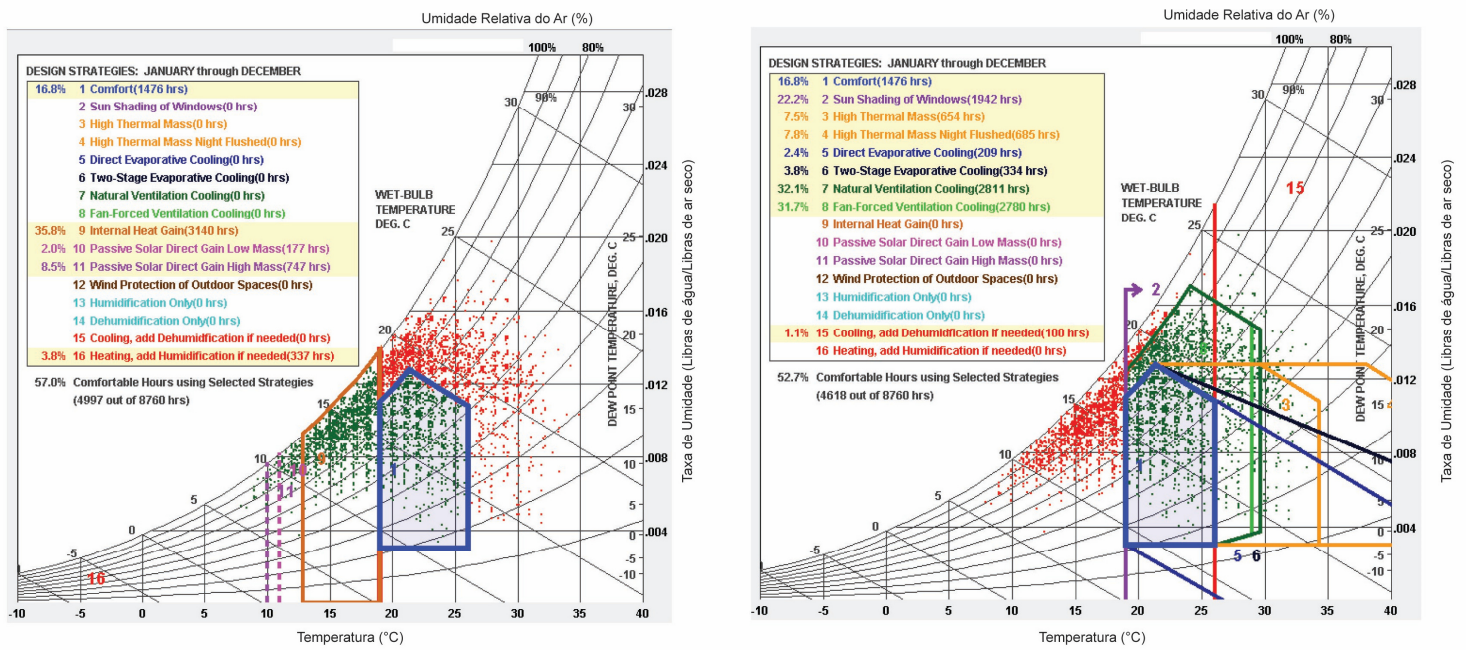

Figura C8: Estratégias para aquecimento (esquerda), e estratégias para resfriamento (direita). Fonte: Climate Consultant 5.5.

O gráfico da direita na Figura B8 demonstra as estratégias para aquecimento. Na Figura B7 (gráfico da esquerda), a estratégia $n^{\circ} 16$, de aquecimento, era indicada para $40,2 \%$ das horas do ano. Com a combinação de estratégias passivas de ganho interno de calor e ganhos solares passivos diretos, a necessidade de aquecimento por sistemas ativos passou a $3,8 \%$ das horas do ano. No caso do resfriamento, o uso de estratégias passivas pode contribuir para que a demanda por sistemas ativos de resfriamento passe de $11,1 \%$ para $1,1 \%$, conforme se observa comparando os gráficos da direita das Figuras B7 e B8. 


\section{ANEXO A}

Carta Psicrométrica com as estratégias indicadas para a cidade de Madri ao longo do ano, a partir da ferramenta Climate Consultant 5.5. Neste caso o modelo de conforto adotado foi o ASHRAE Standard 55 and Current Handbook of Fundamentals Model, que foi o modelo aplicado nos estudos bioclimáticas pela equipe responsável pelas estratégias de conforto térmico no protótipo Ekó House.

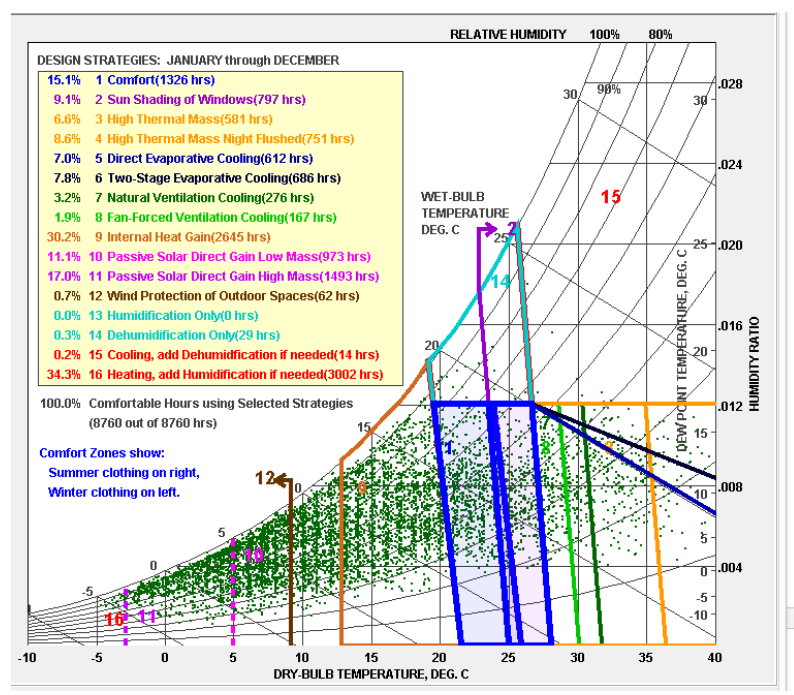

Figura AA1: Carta psicrométrica com as estratégias indicadas para Madri ao longo do ano. Fonte: Climate Consultat 5.5.

\begin{tabular}{cl}
\hline $\mathbf{N}^{\circ}$ & Estratégia \\
\hline $\mathbf{1}$ & Conforto (15,1\%) \\
\hline $\mathbf{2}$ & Sombreamento de aberturas (9,1\%) \\
\hline $\mathbf{3}$ & Alta massa térmica (6,6\%) \\
\hline $\mathbf{4}$ & Alta massa térmica com ventilação noturna (8,9\%) \\
\hline $\mathbf{5}$ & Resfriamento evaporativo direto (7,0\%) \\
\hline $\mathbf{6}$ & Resfriamento evaporativo em dois estágios $(7,8 \%)$ \\
\hline $\mathbf{7}$ & Resfriamento por ventilação natural $(3,2 \%)$ \\
\hline $\mathbf{8}$ & Resfriamento por ventilação forçada (1,9\%) \\
\hline $\mathbf{9}$ & Ganhos internos de calor (30,2\%) \\
\hline $\mathbf{1 0}$ & Ganho solar passivo direto com baixa massa térmica (11,1\%) \\
\hline $\mathbf{1 1}$ & Ganho solar passivo direto com alta massa térmica (17\%) \\
\hline $\mathbf{1 2}$ & Proteção de áreas externas contra ventos $(0,7 \%)$ \\
\hline $\mathbf{1 3}$ & Umidificação $(0 \%)$ \\
\hline $\mathbf{1 4}$ & Desumidificação $(0,3 \%)$ \\
\hline $\mathbf{1 5}$ & Resfriamento e desumidificação se necessário $(0,2 \%)$ \\
\hline $\mathbf{1 6}$ & Aquecimento e umidificação s e necessário $(34,3 \%)$ \\
\hline
\end{tabular}

Tabela AA1: Percentual de horas no ano em que cada estratégia se mostra efetiva para a cidade de Madri. Fonte: A partir de Climate Consultant 5.5. 